\title{
Reducing Ultra-Clean Transportation Fuel Costs with HyMelt ${ }^{\circledR}$ Hydrogen
}

\author{
Quarterly Report
}

July 1 - September 30, 2003

\section{October 31, 2003}

Work Performed Under Cooperative Agreement No. DE-FC26-02NT41102

For

U.S. Department of Energy

National Energy Technology Laboratory

P.O. Box 10940

626 Cochrans Mill Road

$\mathrm{M} / \mathrm{S}$ 922-273C

Pittsburgh, PA 15236-0940

By

Donald P. Malone and William R. Renner

EnviRes LLC

1517 Bull Lea Drive

Suite 200

Lexington, KY 40511 


\section{DISCLAIMER}

This report was prepared as an account of work sponsored by an agency of the United States Government. Neither the United States Government nor any agency thereof, nor any of their employees, makes any warranty, express or implied, or assumes any legal liability or responsibility for the accuracy, completeness, or usefulness of any information, apparatus, product, or process disclosed, or represents that its use would not infringe privately owned rights. Reference herein to any specific commercial product, process or service by trade name, trademark, manufacturer or otherwise does not necessarily constitute or imply its endorsement, recommendation, or favoring by the United States Government or any agency thereof. The views and opinions of authors expressed herein do not necessarily state or reflect those of the United States Government or any agency thereof. 


\begin{abstract}
This report describes activities for the fourth quarter of work performed under this agreement. A second round of atmospheric testing was conducted as scheduled on September 2 through September 4, 2003. The test results demonstrated a much-improved rate of carbon dissolution with gas yields close to expectations. Additional atmospheric testing to demonstrate a commercially feasible feed and oxygen injection method is scheduled for the week of December $8,2003$.
\end{abstract}




\section{TABLE OF CONTENTS}

1.0 Project Objectives, Scope and Description of Tasks

\section{$1.1 \quad$ Introduction}

1.2 Scope of Work

\subsection{Phase I Task Description}

2.0 Executive Summary of Work Done During This Reporting Period

3.0 Experimental

4.0 Results and Discussion

5.0 Conclusion

6.0 References

7.0 Plans for the Next Quarter

Appendix I MEFOS DATA

Appendix II Kvaerner CO-Water Gas Shift Studies

Appendix III Siemens Westinghouse Power Corporation 


\subsection{PROJECT OBJECTIVES, SCOPE AND DESCRIPTION OF TASKS}

\section{Introduction}

EnviRes and DOE executed the cooperative agreement for this work on September 19, 2002. This document is the fourth quarterly progress report under this agreement. Kvaerner, MEFOS and Siemens Westinghouse will conduct most of the significant tasks in this project through subcontracts with EnviRes.

\section{$1.1 \quad$ Scope of Work}

Phase I of the work to be done under this agreement consists of conducting atmospheric gasification of coal using the HyMelt technology to produce separate hydrogen rich and carbon monoxide rich product streams. In addition smaller quantities of petroleum coke and a low value refinery stream will be gasified. DOE and EnviRes will evaluate the results of this work to determine the feasibility and desirability of proceeding to Phase II of the work to be done under this agreement, which is gasification of the above-mentioned feeds at a gasifer pressure of approximately 5 bar. The results of this work will be used to evaluate the technical and economic aspects of producing ultra-clean transportation fuels using the HyMelt technology in existing and proposed refinery configurations.

\subsection{Phase I Task Description}

Task 1.1 Project Management and Planning

This task includes all project planning; experimental test plans; risk analysis; implementation of a bridge loan, purchasing, contracting and accounting systems with requisite auditing; and execution of contracts with MEFOS, Kvaerner and Siemens Westinghouse. This task is being executed.

Task 1.2 Preparation and Shipment of Feedstock Materials

This task consists of procuring 25 tons of coal, 15 tons of petroleum coke and $48-55$ gal drums of aromatic extract oil; transporting the coke and coal to a pulverizing facility; pulverizing, drying and loading the coke and coal into bags; and shipping the feedstocks to MEFOS in Lulea, Sweden. EnviRes completed this task

Task 1.3 Predictive Modeling of the HyMelt Process

This task consists of generating detailed reactor energy and material balances for each feedstock using the Fact Sage pyrometallurgical thermodynamic modeling program. Kvaerner will perform detailed process simulation using the Aspen Plus process simulator. Kvaerner, MEFOS and EnviRes will evaluate and analyze the results of predictive modeling. This task is being executed. 
Task 1.4 Combustion Modeling and Analysis

Siemens Westinghouse will perform combustion turbine modeling using fuel gas conditions and compositions provided by task 1.3. This task is being executed.

Task 1.5 Design and Fabrication of Pilot Plant Specific Molten Iron Bath Apparatus

MEFOS will design and fabricate all solid feeding systems and oxygen injection systems required by the testing. EnviRes will assist MEFOS in designing the petroleum liquid feed system. MEFOS will design the shell of the high-pressure reactor. MEFOS and EnviRes completed the originally planned injection system for this task. MEFOS and EnviRes designed and fabricated a tuyere for submerged injection. MEFOS and EnviRes are currently designing and fabricating a commercially feasible tuyere for testing in December.

Task 2.0 Project Testing

Task 2.1 HyMelt Atmospheric Pressure Testing in a Molten Iron Bath

MEFOS designed and fabricated the petroleum liquid feed system. This injection system was tested in a cold flow environment. The injection systems were hot commissioned. Any equipment revisions indicated by cold flow testing and hot commissioning were made. Process performance testing was performed for each feed. Execution of this task continues.

\subsection{EXECUTIVE SUMMARY OF WORK DONE DURING THIS REPORTING PERIOD}

Experimental testing of coal, petroleum coke and a heavy oil began on June 5 and continued through June 13. We believe that these tests represent the first instance of injection of these feeds into molten iron without the concurrent injection of substantial quantities of oxygen and other materials. The tests in June resulted in unacceptably low rates of carbon dissolution in the molten iron. Preliminary results from tests conducted in September indicate that much better carbon dissolution rates result from submerged injection. We have scheduled additional atmospheric testing using tuyeres for both oxygen injection and coal or coke injection to begin December 8, 2003. The December testing will operate in a commercially practical mode.

An economic evaluation by Kvaerner indicated that water gas shifting of carbon monoxide is prohibitively expensive at $\$ 2.86$ per kscf of incremental hydrogen produced over the fuel value of the feed carbon monoxide. HyMelt, unlike most other coal gasification processes, does not require water gas shifting to produce high purity hydrogen. Detailed flow sheets, equipment sizing, equipment cost, and preliminary operating cost estimates are presented in this report. Kvaerner obtained cost estimates from UOP for Polybed PSA hydrogen purification.

EnviRes and Siemens Westinghouse Power Corporation decided to evaluate catalytic burners for gas turbines using the carbon monoxide rich fuel gas from the HyMelt process. If performance similar to that already demonstrated with natural gas can be achieved with HyMelt fuel gas, we believe that post combustion abatement controls will not be required to meet currently envisioned new source performance standards for $\mathrm{NO}_{\mathrm{x}}$ and $\mathrm{CO}$ emissions. 
Brad Quinlan, auditor for the Defense Contract Audit Agency [DCCA] under contract by the U.S. Department of Energy, conducted a follow-up audit of the financial reporting and accounting system of EnviRes on July $9 \&$ 10. An exit conference with Daniel French, EnviRes Controller, was conducted on July 10. On July 25 we received an electronic copy of the audit report concluding, "EnviRes' accounting system is adequate for accumulating costs under Government contracts".

\subsection{Experimental}

\section{MEFOS Activities}

As described in the previous quarterly report, testing using coal, coke and liquid petroleum injection were conducted from June 5 through June 13. Appendix I contains a detailed description of this work reported by MEFOS. MEFOS generated a large amount of data in this work. The data presented represent a summary of the data generated and still the data presentation takes tens of pages. The raw data from which MEFOS generated this summary can only be managed electronically.

The MEFOS report in Appendix I points out that some problems in sampling and analyzing streams occurred during the test program. Some of these problems included air infiltration into the process gas sample lines between the sample probe and the analytical equipment, calibration drift for the mass spectrometer, feed misidentification and other problems that were not clearly identified. Most of these problems can be corrected by standard data reconciliation techniques. Since the volume of data is great, data reconciliation represents a long and arduous task that would consume substantial resources and money. As we will describe later, the rate of carbon dissolution into the metal for the June test program was unacceptably low. Initial data analysis of work performed in early September indicate that we achieved acceptable carbon dissolution rates for at least some of the injection periods and that the quality of the gas analysis was better than that generated in June. We will, therefore, focus attention and resources on test periods that represent commercially attractive operating conditions. Our analysis of the June data will review the useful data generated with greater effort reserved for later work.

The MEFOS report in Appendix I describes the equipment, the materials used, the testing procedure and the heat notes in sufficient detail so that no further comment regarding them will be made. Additional comments on the results will be made in section 4.0 Discussion.

Preliminary analysis of the data generated June 5 to 13 indicated that carbon dissolution rates into the metal were unsatisfactory. MEFOS and EnviRes concluded that the problem was caused by problems associated with top entry lances. We further concluded that although significant improvements could be made to top entry lances and the way they are utilized, most of these improvements were not achievable within the financial and time constraints of this project. MEFOS suggested that we test tuyeres for coal and petroleum coke injection. The quickest, most cost effective, most likely to succeed approach was to use a side entry lance 10 $\mathrm{cm}$ from the bottom of the refractory lining. The initial tuyere to be tested was a single lanyard (one tube) design. Argon would transport the solid feed from the feed hopper to the tuyere. Figure 1 is a view of the universal converter with the lance installed. The single rubber hose 
conveys the pneumatically transported particulate to the tuyere near the center of the figure. The stainless steel tubing connects a pressure gauge (to the top) allowing the inlet pressure to the tuyere to be monitored. The universal converter is tilted to the charging or tapping position in Figure 1. The hood that collects product gases and air for combustion appears at the very top of the figure. A connection for bottom stirring (not connected) appears at the lower left.

On Tuesday, September 2, 2003 we made several injection attempts with coal and petroleum coke. All attempts resulted in an occluded tuyere (the pressure drop across the tuyere was high and there was almost no flow). We observed that a solid accretion had formed on the inside wall of the universal converter at or near the location of the tuyere outlet. Figure 2 shows a dark formation near the tuyere outlet that appears to be a metal accretion.

We decided to use a slit tuyere in place of the single lanyard tuyere. Figure 3 shows an end view of the slit tuyere. A slit tuyere consists of two concentric pipes with the OD of the inner pipe only slightly smaller than the ID of the outer pipe. Such a design is much more resistant to metal intrusion into the annular space. We decided to inject air in the annular space and coal in the center pipe. The center pipe ID was $8.0 \mathrm{~mm}$. We felt that the slightly exothermic effect of the small amount of injection air would retard or prevent accretion formation. MEFOS worked into the night to install the new tuyere. Figure 4 shows the installation of the slit tuyere in the universal converter. This view is similar to Figure 1. Note that there are two hoses. The original rubber hose still transports the solid feed. The second hose transports the air for the slit tuyere. We resumed testing on the morning of September 3. Little difficulty was encountered with coal or coke injections after installing the slit tuyere.

Figure 5 shows the temperature probe just after its removal from the universal converter. The outer wall of the temperature probe is approximately $8 \mathrm{~mm}$ of rolled cardboard. In the absence of oxygen, which is the case in the universal converter, the cardboard lasts for more than 30 seconds even when immersed in molten iron. This is longer than the insertion time of the probe. The temperature probe measures the temperature one time before it is discarded. MEFOS measured the metal temperature approximately once every 2 minutes during feed injection or oxygen injection and at least once, with a different probe, every time the universal converter was tilted.

Figure 6 shows the metal sample probe just after its removal from the universal converter. The sample probe also has a cardboard outer wall. The tip of the sample probe has a hollow ceramic cavity that allows metal to enter and freeze. The Tip is covered with a metal shroud that prevents slag from entering the cavity as the probe passes through the slag layer. The shroud melts in the molten iron. The probe can sample metal from 10 to $20 \mathrm{~cm}$ below the metal surface. MEFOS took metal samples using this method approximately once every 10 minutes. MEFOS also took metal samples with a different probe when the converter was tilted. The hopper and chute in the right center of both Figures 5 and 6 allows lime, scrap and fluxing agents to be added to the universal converter during operation. 


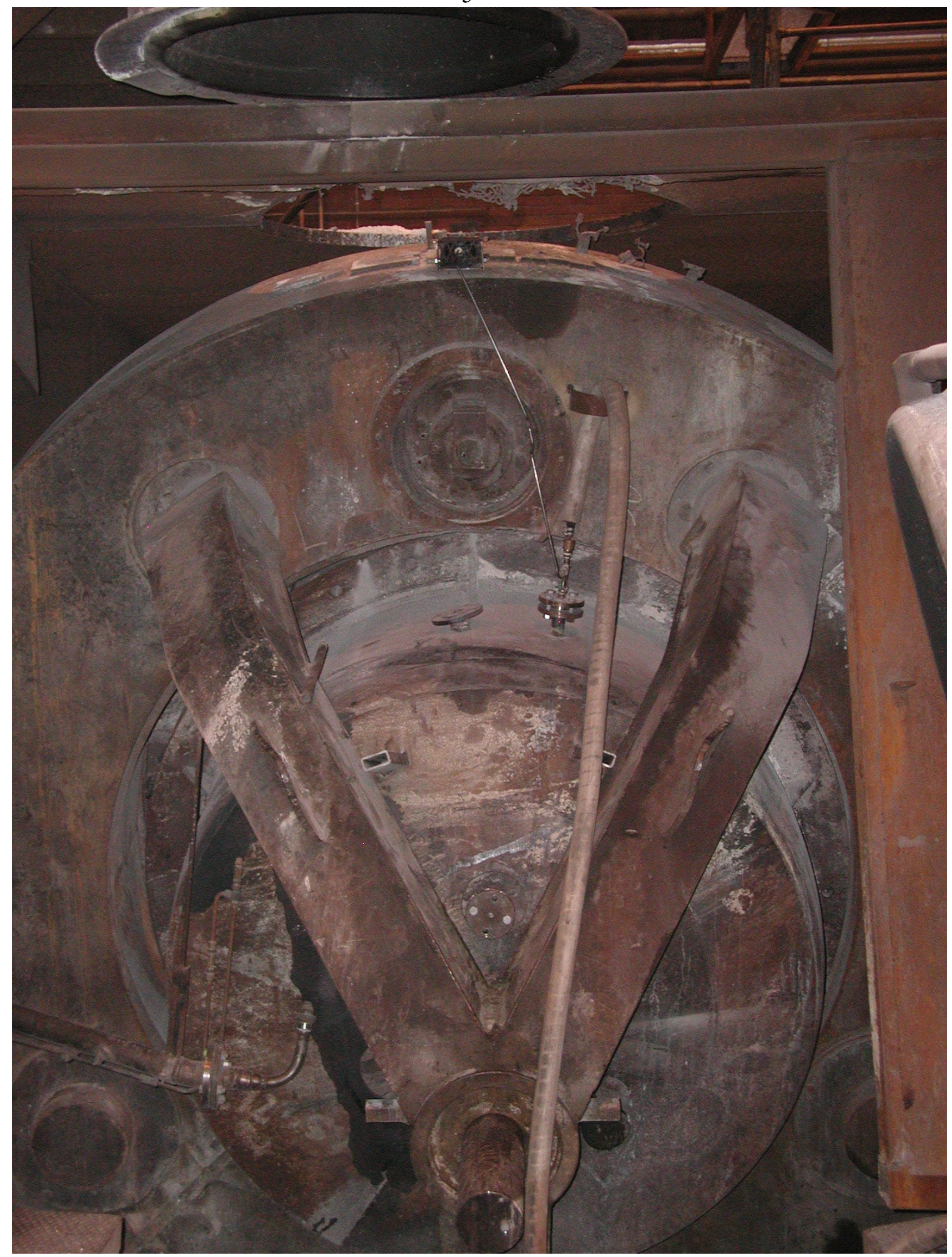

Figure 1. Initial Tuyere Installation in the Universal Converter 


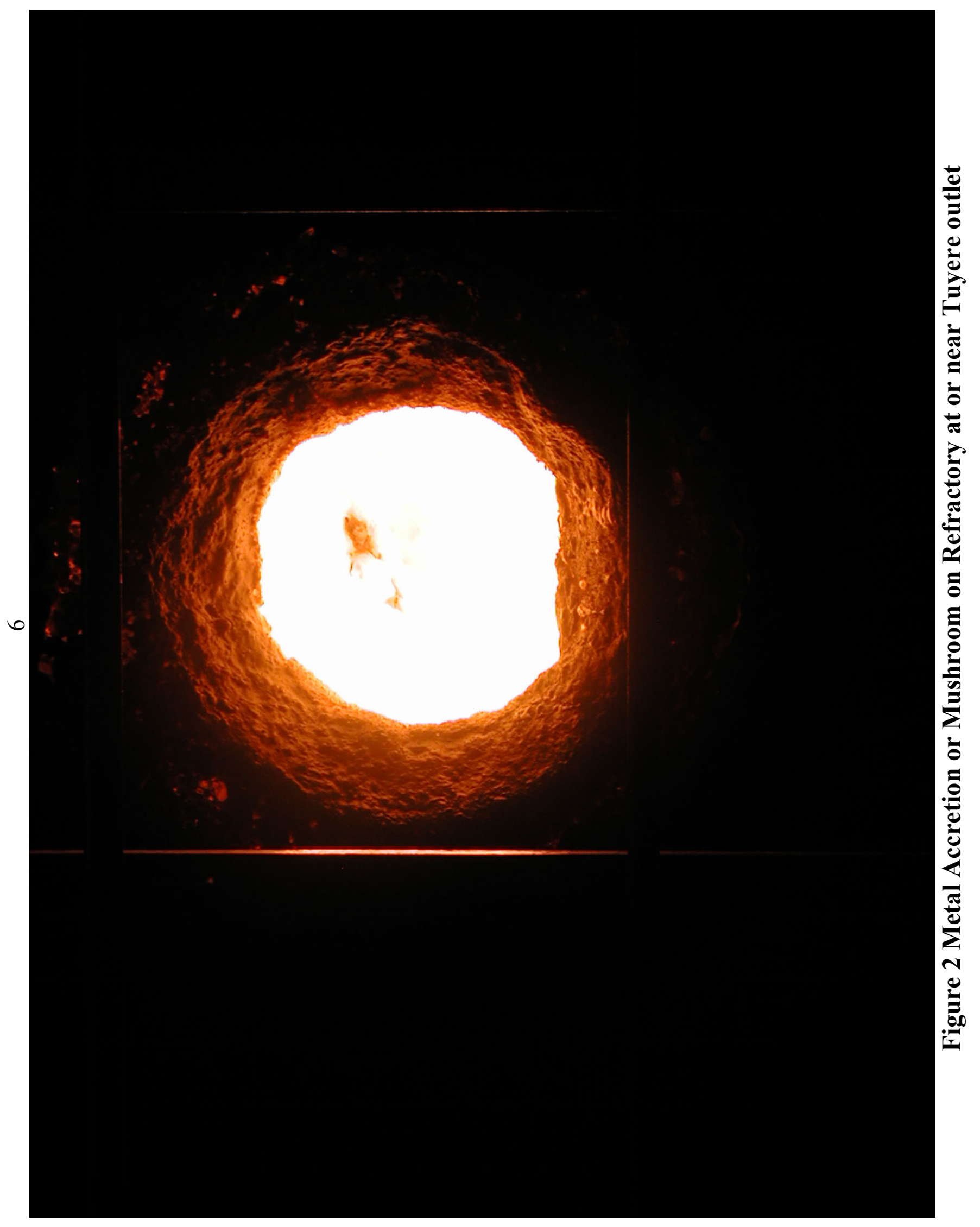




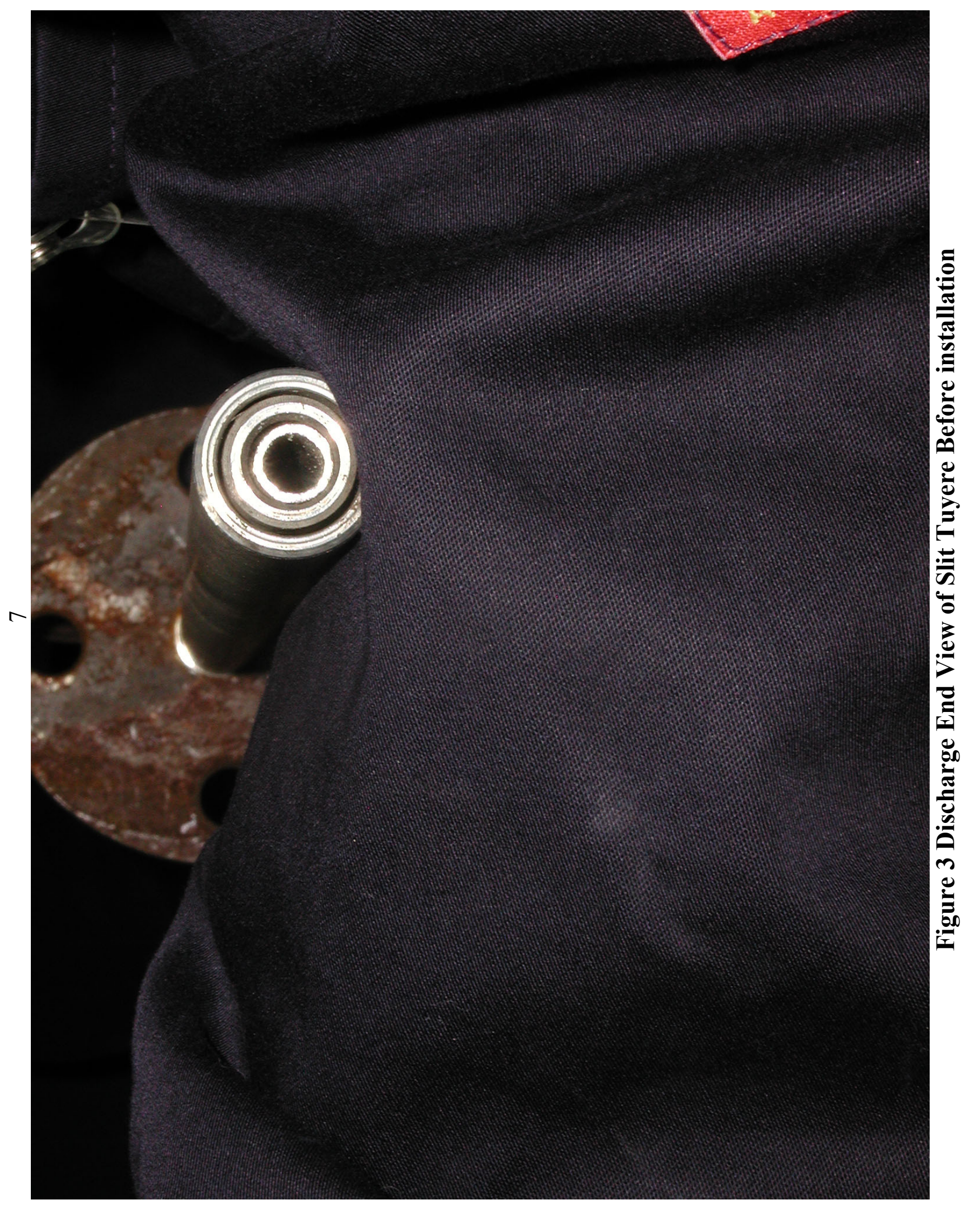




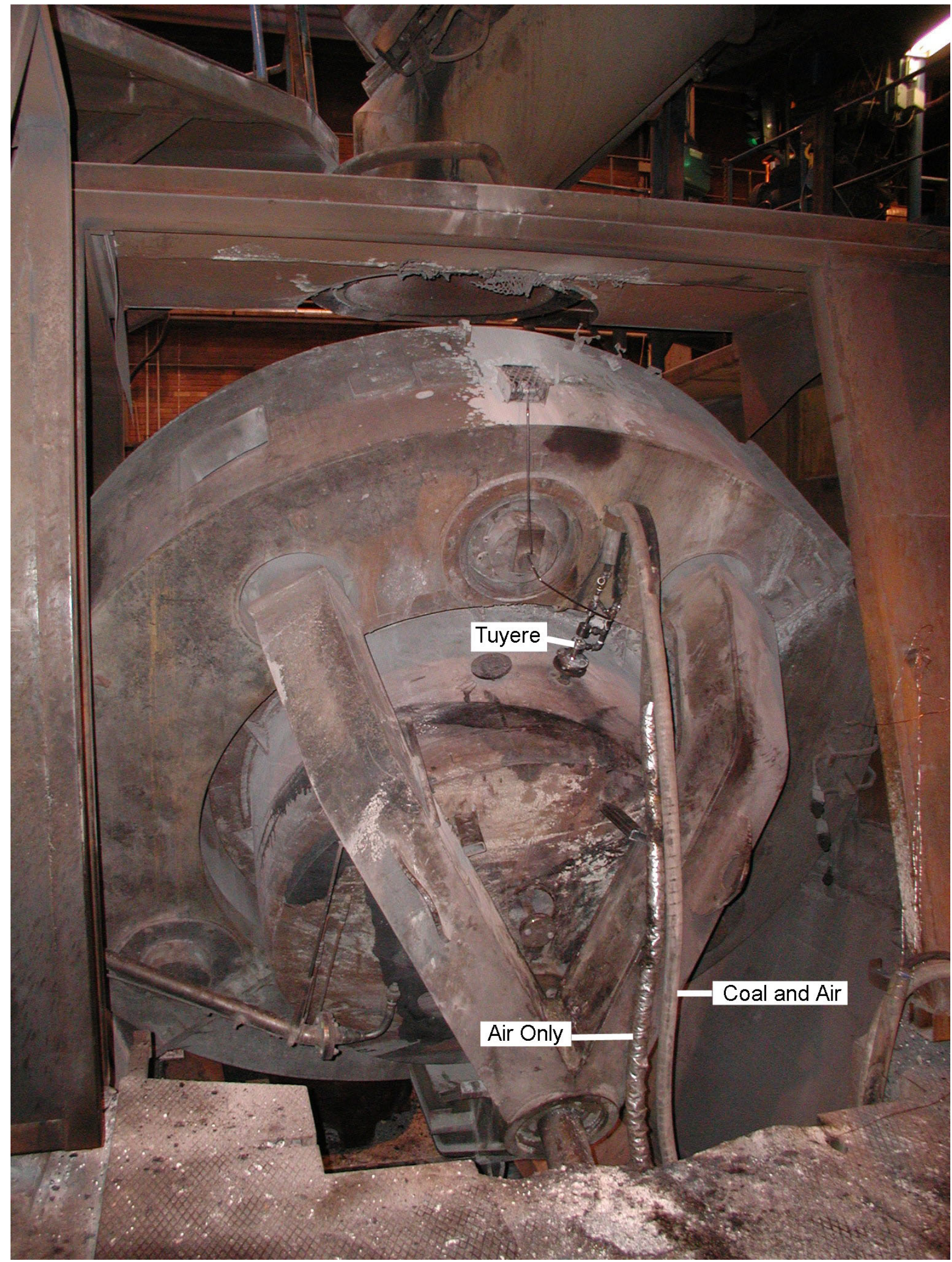

Figure 4. Slit Tuyere Installed on the Universal Converter 


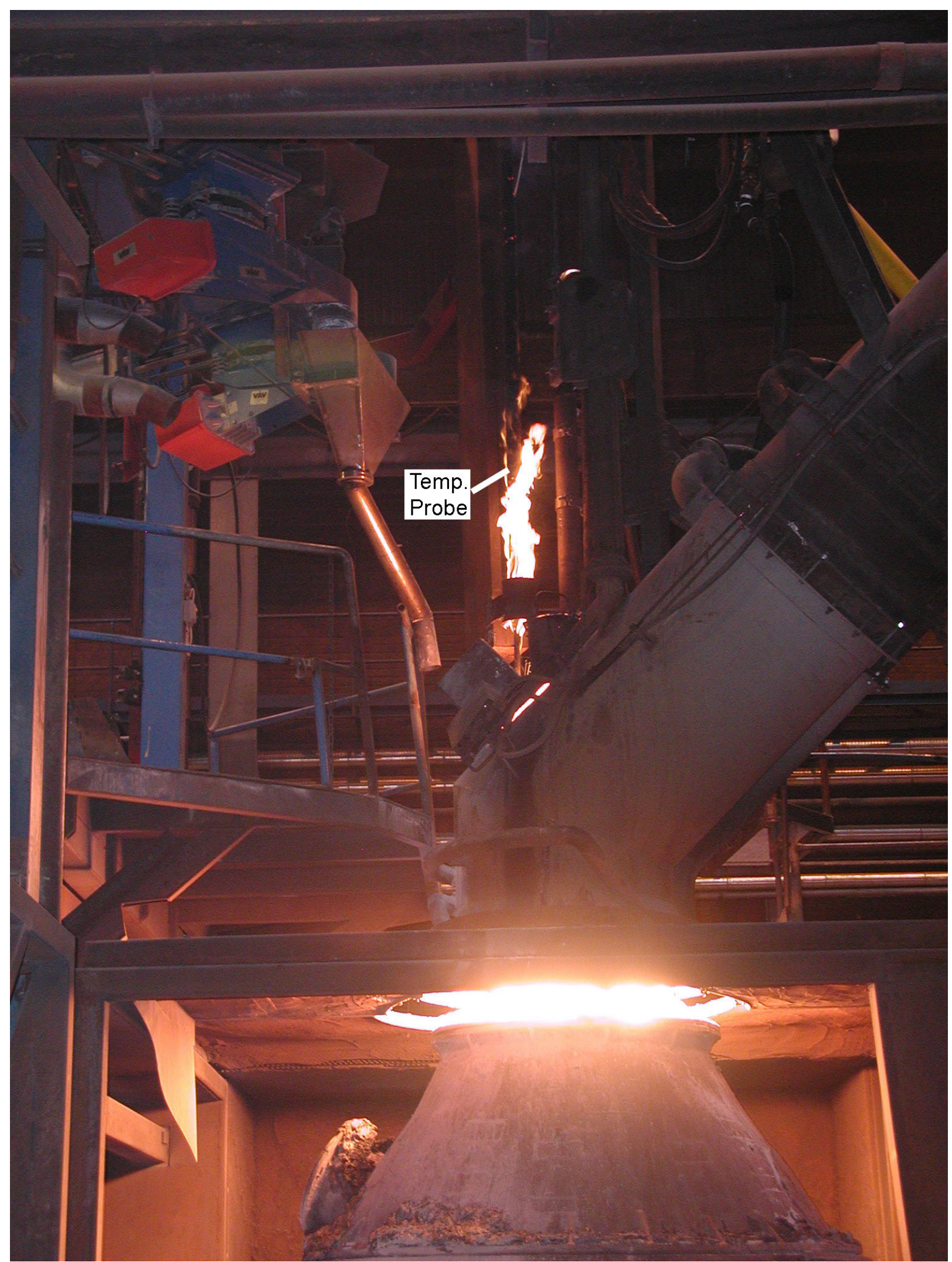

Figure 5. Temperature Probe Removal During Decarburization for Universal Converter 


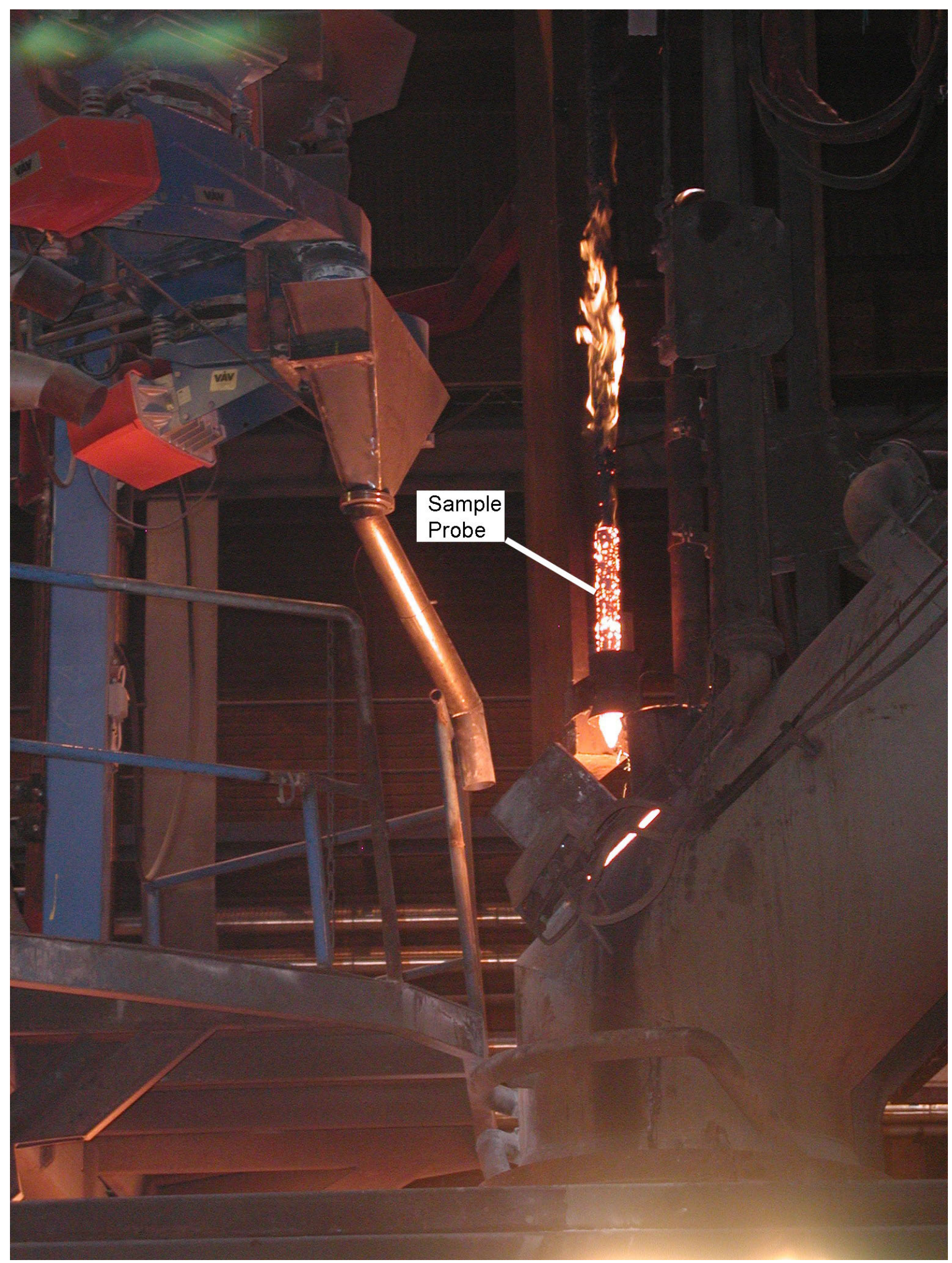

Figure 6 Metal Sample Probe Removal During Decarburization 


\section{Kvaerner Activities}

Kvaerner initiated simulation activities using Aspen Plus. The HyMelt reactor section process flow sheet appears in Appendix II page 2, the flow sheet for the amine system appears in Appendix II on AII page 15 stream flows for this flow sheet appear on AII page 14 and the flow sheet for the water gas shift appears in Appendix II on AII page16 stream flows for this flow sheet appear on AII page 17 to 19. Kvaerner obtained cost estimates from Dow for the amine system and UOP for the PSA hydrogen purification system. This information is also given in Appendix II. Kvaerner estimated the differential cost for shifting nearly all of the carbon monoxide produced in a $450 \mathrm{t} / \mathrm{d}$ demonstration plant.

\section{Siemens Westinghouse Power Corporation Activities}

EnviRes, Siemens Westinghouse Power Corporation and some consultants of Siemens Westinghouse discussed the merits of diffusion and catalytic burners for gas turbines. We decided to evaluate a catalytic burner because it offers the potential of meeting future $\mathrm{NO}_{\mathrm{x}}$ emission requirements without a selective catalytic reduction (SCR). Appendix III contains most of the information developed for this issue.

\subsection{Results and Discussion}

\section{MEFOS Activities}

For all injections performed in June, the methane content of the product gas was in the range of 5 to $10 \%$. In some tests coke could be seen floating on the slag when the universal converter was tilted after injection. Dust samples contained as much as $90 \%$ carbon. Pages 49 to 51 of the MEFOS report show the carbon yield to metal for coal, petroleum coke and aromatic extract oil. Carbon yield to metal is calculated as the quotient of the change in the total mass of carbon dissolved in the metal divided by the total mass of carbon contained in the injectant for that period. The change in the total mass of carbon in the metal is calculated as the product of the mass of metal in the bath and the change in the weight fraction of carbon in the metal from the beginning to the end of the injection period. Since the yield is expressed as a percentage, the above quotient should be multiplied by $100 \%$.

The maximum value for carbon yield to metal must always be less than $100 \%$ for several reasons. First, any oxygen contained in the feed will convert in near quantitative fashion to carbon monoxide. With Illinois \#6 coal having $8.26 \%$ oxygen, the amount of carbon in the feed not reporting to the metal by this mechanism should be 7 to $10 \%$ of the feed carbon. If the coal moisture content increased during storage, this number will be higher. Similarly any methane formed will reduce the amount of carbon reporting to the metal from the feed although the thermodynamic amount of methane should always be less than $1 \%$ at these conditions. Second, any $\mathrm{FeO}$ present in either the metal or slag from decarburization will react with feed carbon to form carbon monoxide. In this case the value of carbon monoxide produced will have a maximum value near the beginning of the injection period and decrease as oxygen is consumed. Third, any slag reactions such as $\mathrm{CaO}+\mathrm{C}+\mathrm{S} \rightarrow \mathrm{CaS}+\mathrm{CO}$ will consume carbon that would otherwise report to the metal. Slag reactions should consume very little carbon since the ratio of slag to metal is always small. 
Top entry oxygen blowing typically created substantially more $\mathrm{FeO}$ in the slag than does tuyere injection of oxygen. Values of $\mathrm{FeO}$ in the slag are given in the MEFOS report in Appendix I. $\mathrm{FeO}$ in the slag after oxygen blowing typically ranged from 5 to $15 \%$.

The carbon yield to metal for coal ranged from $59.6 \%$ to $13.7 \%$, for petroleum coke the values ranged from 72.4 to $22.4 \%$ and for oil the values ranged from $33.4 \%$ to $11.4 \%$. The oil injection differed significantly from the method of injection for coal and petroleum coke. The carbon yield to metal for petroleum coke and coal become nearly equal when the effect of oxygen contained in the coal is considered. For both petroleum coke and coal the carbon yield to metal decreased with increasing feed rate. The decrease in transport gas flow rate with increasing solid flow and thus the velocity of the gas particulate stream impinging on the slag/metal surface may explain at least in part the decrease of carbon to metal with feed rate.

MEFOS discusses many of the trends in product gas compositions. Several problems with sampling and analysis combined with injection problems, described earlier make detailed analysis of the gas compositions questionable without significant effort to correct for these problems. It is unclear whether the high $\mathrm{COS}$ values result from the high $\mathrm{FeO}$ levels in the slag. It is unclear whether oxygen in air leakage into the sample lines to various analyzers reacted with hydrogen and/or CO.

The results of mercury sampling and analysis show a wide range of mercury levels if the data are correct. We only sampled and analyzed the product gas for mercury three times during June testing.

The hydrogen-purging test for sulfur removal described on page 49 of the MEFOS report shows that much more sulfur disappeared from the metal and slag than could be accounted for by the amount of $\mathrm{H}_{2} \mathrm{~S}$ appearing in the product gas. Similar unexplained sulfur disappearance from the metal was always experienced in the early bench scale tests.

The vanadium tests show that vanadium has a partition coefficient that is highly dependent on the oxygen potential. These tests (page 35 and 43 of the MEFOS report) also show that vanadium in the slag can be reduced causing the vanadium to report back to the metal after it has been oxidized from the metal into the slag for vanadium levels of 0.6 to $0.8 \%$ in the metal.

\section{Kvaerner Activities}

Kvaerner completed an economic comparission of using the carbon monoxide rich stream for fuel vs. shifting the carbon monoxide rich stream to hydrogen. Results of this work are given in Appendix II. UOP estimated a cost of $\$ 1.7 \mathrm{MM}$ for a Polybed PSA system capable of producing 15.31 MMSCFD of product hydrogen UOP estimated a cost of \$2.5 MM for a unit capable of producing 28.39 MMSCFD. Kvaerner obtained or determined detailed flow sheets, material balances, energy balances, equipment sizing and operating costs. Kvaerner obtained or determined similar information from Dow for an amine system to remove $\mathrm{H}_{2} \mathrm{~S}$ from the product hydrogen. As presented in Appendix II Kvaerner determined that the incremental cost over fuel value for upgrading the carbon monoxide rich HyMelt stream was $\$ 2.86$ per $\mathrm{kSCF}$ of hydrogen produced. 


\section{Siemens Westinghouse Power Corporation Activities}

EnviRes and Siemens Westinghouse decided to model and test a catalytic burner instead of a diffusion burner for proposed gas turbines using the carbon monoxide rich stream as fuel. Most if not all combustion systems for IGCC turbines use diffusion burners to combust carbon monoxide rich fuel. These burners simply provide residence time and mixing for combustion to take place. Diffusion burners tend to produce $\mathrm{NO}_{\mathrm{x}}$ levels of $25 \mathrm{ppmv}$ when the flue gas is adjusted to a standard value for excess oxygen. Diffusion burners usually produce $\mathrm{CO}$ emissions in excess of 5 ppmv. It is likely that new source performance standards will require both $\mathrm{NOx}$ and $\mathrm{CO}$ emissions to be below 3 ppmv for power plants by the time a commercial HyMelt plant is built. If both of these hypotheses are correct, combustion turbines (including those firing natural gas) will be required to have post combustion abatement controls for both $\mathrm{NO}_{\mathrm{x}}$ and CO. While diffusion burners have not been specifically tested with a fuel that is representative of the carbon monoxide rich stream from HyMelt, we believe that the results would be very similar.

Siemens Westinghouse had a catalytic burner program under development before this project began. They have tested a prototype of their catalytic burner with natural gas at commercial conditions. In these test they found that $\mathrm{NOx}$ and $\mathrm{CO}$ emissions could be kept under 2 ppmv under optimal operating conditions. If similar results can be obtained for the HyMelt carbon monoxide rich stream, gas turbines using catalytic burners may not require post combustion abatement controls for a HyMelt gasifier. This appears to us to be a strong incentive to pursue catalytic burners. If catalytic burners are not feasible for HyMelt carbon monoxide rich gas we can switch to diffusion burners with very little uncertainty.

\subsection{Conclusions}

All testing conducted from June 5 to 13 gave unacceptable carbon dissolution rates. At low feed rates both petroleum coke and coal resulted in approximately $70 \%$ of theoretical. At higher feed rates the rate of carbon dissolution dropped rapidly to near $20 \%$ of theoretical. Carbon dissolution rates for oil were even worse. Carbon dissolution rates could be improved with better injection lance design, but we feel that the probability of obtaining $98 \%$ of theoretical is unlikely with top entry lances.

Preliminary results based on visual observation and preliminary operating data indicate that submerged injection of coal and petroleum coke results in a much better carbon dissolution rate. The carbon dissolution rate also appears to be less dependent on coal or coke feed rate.

Hydrogen purging to remove sulfur does not appear to be attractive, however, during the testing much more sulfur disappeared than could be accounted for by $\mathrm{H}_{2} \mathrm{~S}$ appearing in the product gas. Further investigation of this phenomenon appears warranted.

Based on the economic analysis by Kvaerner, we believe that shifting carbon monoxide to hydrogen is not economically attractive at an incremental cost of $\$ 2.86 / \mathrm{kSCF}$ above fuel value. We further conclude that gasification processes that must use water gas shift to produce hydrogen are at a disadvantage to processes that directly produce hydrogen. 
Catalytic burners for gas turbines using HyMelt carbon monoxide rich fuel gas may not require post combustion abatement controls. If this possibility comes to fruition, it will produce a significant economic benefit for power generation.

\subsection{References}

No references were cited in this document.

\subsection{PLAN FOR THE NEXT QUARTER}

Additional atmospheric testing is scheduled for the second week of December 2003. The testing will last 3 days. Illinois \#6 coal and petroleum coke will be the feeds to be tested using bottom tuyeres. The tuyeres used in this testing will simulate commercial operation. We have delayed final design and procurement of the vessel for super-atmospheric testing until completion of the December testing.

Kvaerner will continue evaluating amine systems and complete the carbon monoxide shift study. Kvaerner will begin atmospheric test data evaluation for commercial design studies.

EnviRes and Siemens Westinghouse have finalized all input parameters for a combustion testing and Siemens Westinghouse will begin combustion simulations in the upcoming quarter. 
APPENDIX I

MEFOS DATA 
Box 812, 97125 LULEA

\begin{tabular}{|llll|}
\hline Dokument: & Tekniskt meddelande & Reg nummer: & TM03037K \\
Fo-uppgift: & Datum: & $2003-08-20$ \\
Konto: 386550 & Rev datum: & \\
Ämnesomr: & Avdelning: & MM \\
& & & \\
\hline \hline
\end{tabular}

HYMELT CAMPAIGN 1,

5-13 JUNE 2003

by

Sten Ångström

Godkänd av forskningschef: ..................

Slutlig: Y

Projektledare: Nils-Olov Lindfors

Sekr: acj

Distribution: EB, NOL, SÅ, Don Malone-EnviRes 
DOE03QUAT_RPT04DRAFT.DOC

TABLE OF CONTENTS Page

$1 \quad$ INTRODUCTION 4

2 EQUIPMENT 4

2.1 MEFOS STANDARD EQUIPMENT

2.1.1 ELECTRIC ARC FURNACE

2.1.2 UNIVERSAL CONVERTER

2.1.3 MATERIAL INJECTION SYSTEM

2.1.4 MEASUREMENTS, SAMPLING AND AUTOMATION

2.2 HYMELT EQUIPMENT 9

2.2.1 INJECTION LANCE FOR COAL AND PET-COKE 9

2.2.2 INJECTION LANCE FOR OIL FEED 9

2.2.3 INJECTION SYSTEM FOR AROMATIC EXTRACT 11

2.2.4 LANCE FOR OXYGEN BLOWING 11

2.2.5 BOTTOM PURGING TUYERE 13

2.2.6 GAS AND DUST SAMPLING LANCE FOR CONVERTER ATMOSPHERE 15

3 MATERIAL 17

$\begin{array}{lll}3.1 & \text { INJECTANTS } & 17\end{array}$

$\begin{array}{lll}3.1 .1 & \text { ILLINOIS \#6 } & 17\end{array}$

$\begin{array}{lll}3.1 .2 & \text { PET-COKE } & 17\end{array}$

3.1.3 325 AROMATIC EXTRACT 17

$\begin{array}{lll}3.2 & \text { ADDITIVES } & 17\end{array}$

$\begin{array}{lll}3.2 .1 & \text { LIME MIX } & 18\end{array}$

$\begin{array}{lll}3.2 .2 & \text { ALUMINIUM BARS } & 18\end{array}$

$\begin{array}{lll}3.2 .3 & \text { FERRO SILICON } & 18\end{array}$

$\begin{array}{lll}3.2 .4 & \text { FERRO SULPHUR } & 18\end{array}$

$\begin{array}{lll}3.2 .5 & \text { FERRO VANADIUM } & 19\end{array}$

4 TEST PROCEDURE 19

4.1 Melting 19

4.2 DECARBURISATION OF HOT METAL 19

4.3 Carburisation $\mathrm{H}_{2}$ PROdUCtion 19

4.4 DE-CARBURISATION CO PRODUCTION 20

4.5 TAPPING 20 
$5 \quad$ Heat notes 21

5.1 HyMeLT 1 21

5.2 HYMeLT 2 21

5.3 HyMeLT $3 \quad 22$

5.4 HYMeLT 4

5.5 HYMeLT 5

5.6 HyMeLT 6 24

6 RESULT 24

6.1 Process gas analysis $\quad 24$

$6.1 .1 \mathrm{CO} 224$

$\begin{array}{lll}6.1 .2 & \mathrm{CO}_{2} & 25\end{array}$

$6.1 .3 \mathrm{H}_{2} \quad 25$

$\begin{array}{lll}6.1 .4 & \mathrm{CH}_{4} & 25\end{array}$

$6.1 .5 \mathrm{H}_{2} \mathrm{~S} \quad 25$

6.1.6 CO S 25

$\begin{array}{lll}6.1 .7 & \mathrm{O}_{2} & 25\end{array}$

6.2 Metal ANalysis $\quad 25$

6.2.1 CARBON 27

6.2.2 SULPHUR 29

6.2.3 VANADIUM 32

6.3 Slag ANALYSIS $\quad 34$

6.3.1 IRON OXIDES

$\begin{array}{lll}6.3 .2 & \text { SULPHUR } & 37\end{array}$

6.3.3 VANADIUM OXIDES 40

6.3.4 $\mathrm{BASCAO} / \mathrm{SIO}_{2}$

6.4 TEMPERATURES

6.5 CARBON YIELD TO METAL 48

6.6 VANADIUM BALANCE

6.7 HYDROGEN PURGING

6.8 DUST ANALYSIS

6.8.1 DUST SAMPLED FROM PROCESS GAS 51

6.8.2 DUST SAMPLED FROM COMBUSTED GAS

6.9 MERCURY IN PROCESS GAS

6.10 REFRACTORY WEAR

APPENDICES, 8 


\section{Introduction}

The first test campaign in the development of the EnviRes HyMelt process has been performed at MEFOS. The tests have been made in the 6 ton universal converter equipped with facilities for injection of hydro-carbides and oxygen.

The technical objective was to make preliminary evaluation the process and functional test of the equipment and measuring systems.

The tests were made for:

- Solid feed injection for Illinois \#6 (coal) and Pet-coke (coke)

- Liquid feed injection for 325 Aromatic extract (oil)

- Oxygen blowing

- Gas measurement

- Dust sampling

- Process control

- Process strategies

The campaign was carried out for six days in the period from June 5 to 13, 2003.

This document is a completion of collected data and a preliminary evaluation of the operational results and performance of process equipment and measuring systems.

\section{Equipment}

\subsection{MEFOS standard equipment}

\subsubsection{Electric arc furnace}

The electric arc furnace is a fully ceramic lined AC furnace suitable for melting 4 to 10 ton of steel or hot metal. In the project the furnace was used for production of high carbon iron melt in charges of $5-6$ ton.

Technical data:

- Heat size 4-10 ton

- Trafo 4,9 MVA

- Shell diameter $2800 \mathrm{~mm}$

- Diameter lined2100 mm 


\section{-AI p5 -}

\subsubsection{Universal converter}

The experiments were carried out in MEFOS universal converter. The converter has a nominal max capacity of 6 ton and can be altered into a variety of converter pro??cesses for metal refining. In the experiment the converter was used as a 5,5 ton, top blown vessel with bottom purging of inert gas.

Technical data:

Shell diameter $2000 \mathrm{~mm}$

Diameter lined $1410 \mathrm{~mm}$

Height lined $2893 \mathrm{~mm}$ Lining Far impregnated magnetite Radex ST

Two hoppers above the converter were erected for slag former and cooling scrap addition.

Totally four top lances was mounted:

- Oxygen lance for decarburisation

- Lance for solid injection alternatively lance for liquid injection

- Sub lance for metal sampling and temperature measurements

- Gas suction lance for sampling of process gas from converter gas atmosphere

In the converter bottom, on the half radius from the wall, a bottom tuyere was mounted for inert gas or hydrogen purging. 
-AI p6 -

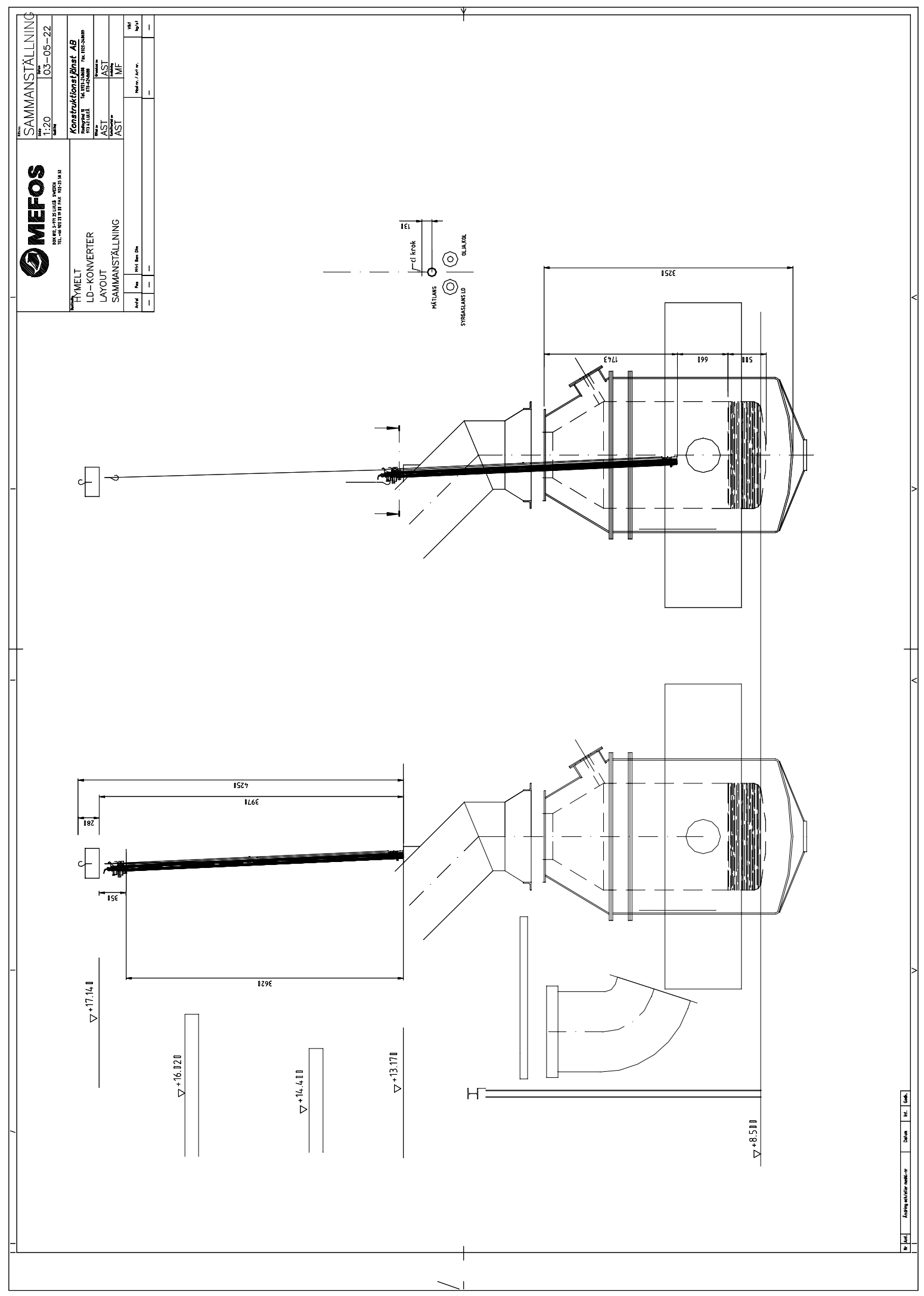


Figure - 1 MEFOS universal converter Hy-Melt, 5 ton, set up

The MEFOS venturie scrubber was used for gas treatment. Before gas cleaning the process gas has to be completely combusted by sufficient amount of air above the converter mouth.

Technical data, venturie scrubber:

Gas flow rate $21000 \mathrm{~m}^{3} \mathrm{n} / \mathrm{h}$

Gas temperature inlet $650{ }^{\circ} \mathrm{C}$

Pressure drop across venturie $500-1900 \mathrm{~mm}$ wq

\subsubsection{Material injection system}

For injection of coal and pet-coke a $3 \mathrm{~m}^{3}$ powder dispenser system was selected. The system has advantages in flexibility regarding blowing conditions and allows handling and charging of fine grained material from "big bags" by use of suction.

Technical data:

Dispenser volume $\quad 3 \mathrm{~m}^{3}$

Spec. transport gas $\quad \sim 0,05 \mathrm{~m}^{3} \mathrm{n} / \mathrm{kg}$

Outlet diameter variable

Max pressure $10 \mathrm{bar}$

\subsubsection{Measurements, sampling and automation}

For process control a set of selected measurements were sampled and evaluated by an inhouse system for converter automation that runs on a LabView platform. The system includes, data logging, standard closed loop regulation and modules for real time evaluation of fundamental process parameters.

Measurements:

Gas supply: range

Oxygen to lance, line $\mathrm{C} \quad 0-20 \mathrm{~m}^{3} \mathrm{n} / \mathrm{min}$

Nitrogen bottom purging, line D $\quad 0-1 \mathrm{~m}^{3} \mathrm{n} / \mathrm{min}$

Nitrogen material transport $\quad 0-1 \mathrm{~m}^{3} \mathrm{n} / \mathrm{min}$ (Operator notes)

Combusted gas

Flow rate, venturi $\quad 0-20000 \mathrm{~m}^{3} \mathrm{n} / \mathrm{h}$

Composition:

$$
\begin{array}{ll}
\mathrm{CO} & 0-5 \% \\
\mathrm{CO}_{2} & 0-20 \% \\
\mathrm{O}_{2} & 0-23 \% \\
\mathrm{SO}_{2} & 0-0,5 \%
\end{array}
$$

Materials

Dispenser weight $\quad 0-3000 \mathrm{~kg}$ 
Bin weights

$$
\begin{array}{ll}
\text { Cooling scrap } & 0-1000 \mathrm{~kg} \\
\text { Lump lime } & 0-1000 \mathrm{~kg} \\
\text { Oil feed } & 0-20 \mathrm{~kg} / \mathrm{min}
\end{array}
$$

Oxygen lance pos $\mathrm{mm}$ above metal surface

Injection lance pos $\mathrm{mm}$ above metal surface

Non-continuous measurements:

$$
\begin{aligned}
& \text { Metal temperature } \quad 0-1800{ }^{\circ} \mathrm{C} \\
& \text { Metal composition }
\end{aligned}
$$

Process gas composition conventional

$\mathrm{CO}$

$\mathrm{CO}_{2}$

$\mathrm{H}_{2}$

Process gas composition mass spectrometer MS 127

$\mathrm{H}_{2}$

Process gas composition mass spectrometer AIR SENSE 2000

$\mathrm{H}_{2}$

$\mathrm{H}_{2} \mathrm{~S}$

$\mathrm{COS}$

$\mathrm{CH}_{4}$
$0-100 \%$

$0-20 \%$

$0-20 \%$

$0-100 \%$

Special measurements and sampling not recorded on the process computer:

Metal weight, charging and tapping

Analysis of sampled metal and slag

Poured slag weights

Dust sampling in converter for composition analysis

Dust sampling in combusted gas for composition analysis and load

Manual additions of Al-bars, $\mathrm{FeSi}, \mathrm{FeV}$ and $\mathrm{FeS}$

Hydrogen gas for bottom purging

In blow metal sampling was made by use of a sub-lance system. Sampling during process stop in tilted converter was manually made. In both cases the samples were either analysed for carbon and sulphur by use of a Leco combustion analyser or sent to SSAB for spark emission spectrometry giving almost a complete analysis. All samples were stored for reference and further evaluations.

Slag sampling was manually made when the converter was tilted. All samples were stored and selected samples were analysed by X-ray at SSAB.

Dust sampling was made by two methods:

1. Process dust from the filter of the converter gas.

2. Iso-kinetic sampling of combusted dust from the duct. 
Process parameters calculated on-line for supervising were:

1. Material injection flow rate

2. Gas flow rate, supply and combusted gas

3. Carbon balance for carburisation yield

4. Oxygen balance for oxygen yield during decarburisation

5. Carbon content in liquid metal

\subsection{HyMelt equipment}

\subsubsection{Injection lance for coal and pet-coke}

A water-cooled lance for solid material injection was designed and constructed. Technical data:

Total length $4800 \mathrm{~mm}$

Diameter $76 \mathrm{~mm}$

Outlet nozzle diameter 7,0 mm, other dimensions were also tested

For transport of material from dispenser to the lance a flexible rubber hose was selected. The hose quality has reasonable abrasive wear resistance and can, with proper heat protections, be used in metallurgical environment.

\subsubsection{Injection lance for oil feed}

A water-cooled lance for oil injection was designed and constructed.

Technical data:

Total length $4800 \mathrm{~mm}$

Diameter $\quad 76 \mathrm{~mm}$

Outlet nozzle diameter $\quad 1,9 \mathrm{~mm}$ 
-AI p10 -

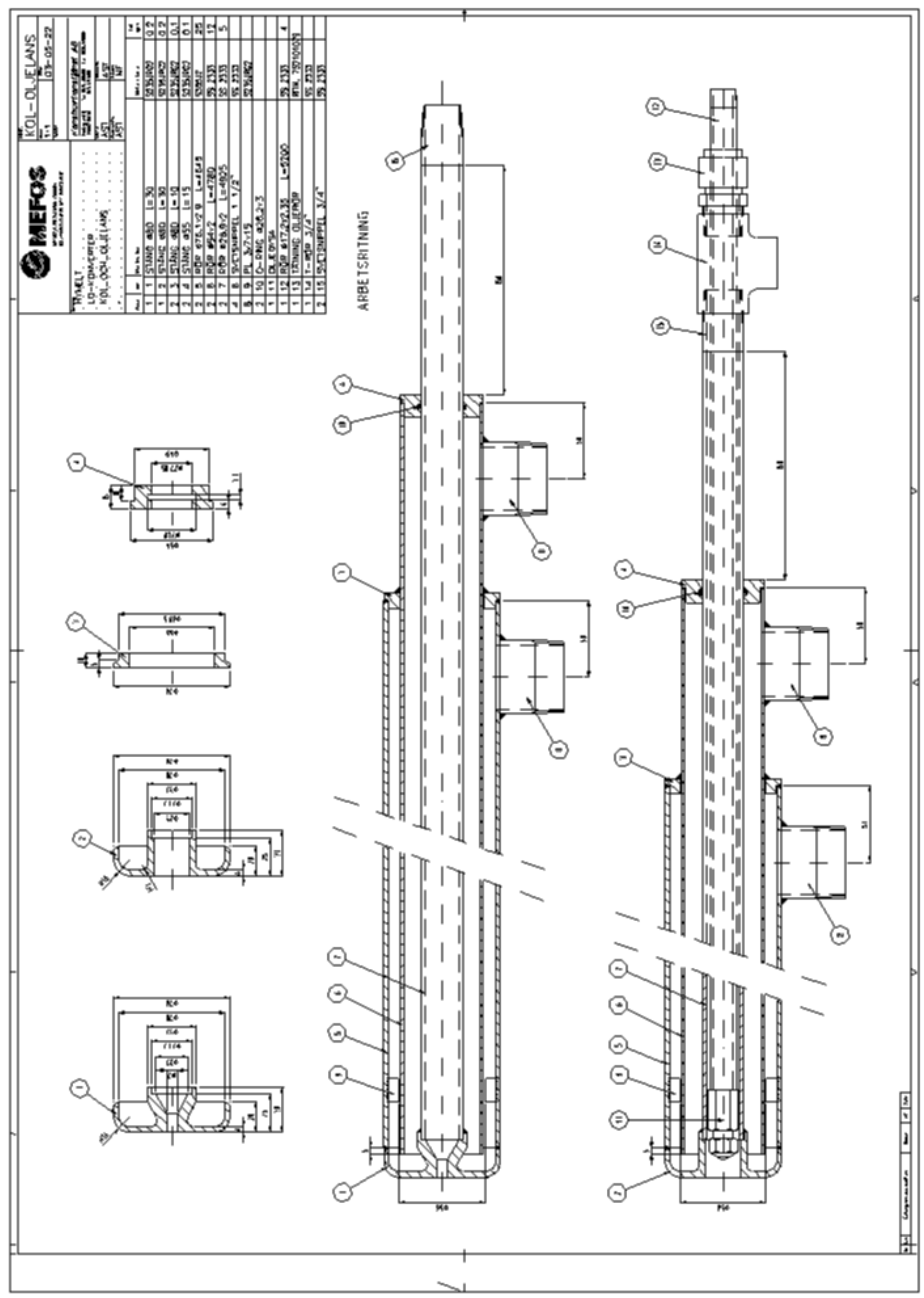


Figure 2 - Water-cooled injection lances for solids and oil

\subsubsection{Injection system for aromatic extract}

A special designed oil injection system was set up for low viscosity oil. The demand for short transport distance of the oil called for special safety arrangements and it was found that the storage tank with heating and the pump were to be mounted in a steel container. The set-up gives sufficient safety for spitting and slag splashing that accidentally generates from oxygen converters.

Technical data:

Storage volume $\quad 3 \mathrm{~m}^{3}$

Max pressure 22 bar

Nominal oil feed rate $10 \mathrm{~kg} /$ minute

\subsubsection{Lance for oxygen blowing}

The oxygen lance was designed as a water cooled single Laval nozzle for BOF converters.

Technical data:

Total length $4800 \mathrm{~mm}$

Diameter

Nominal flow rate $10 \mathrm{~m}^{3} \mathrm{n} / \mathrm{min}$

Outlet nozzle diameter $\quad 15,5 \mathrm{~mm}$

Mach No 
-AI p12 -
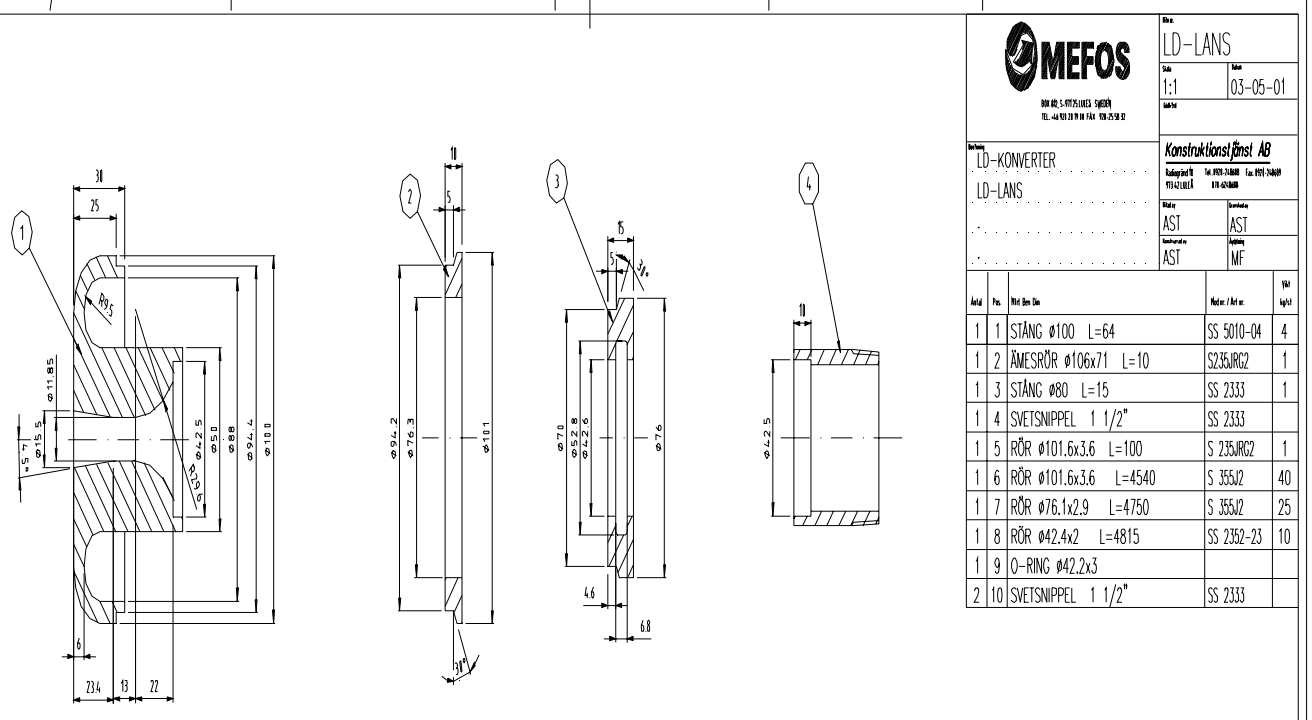

ARBETSPITNNG

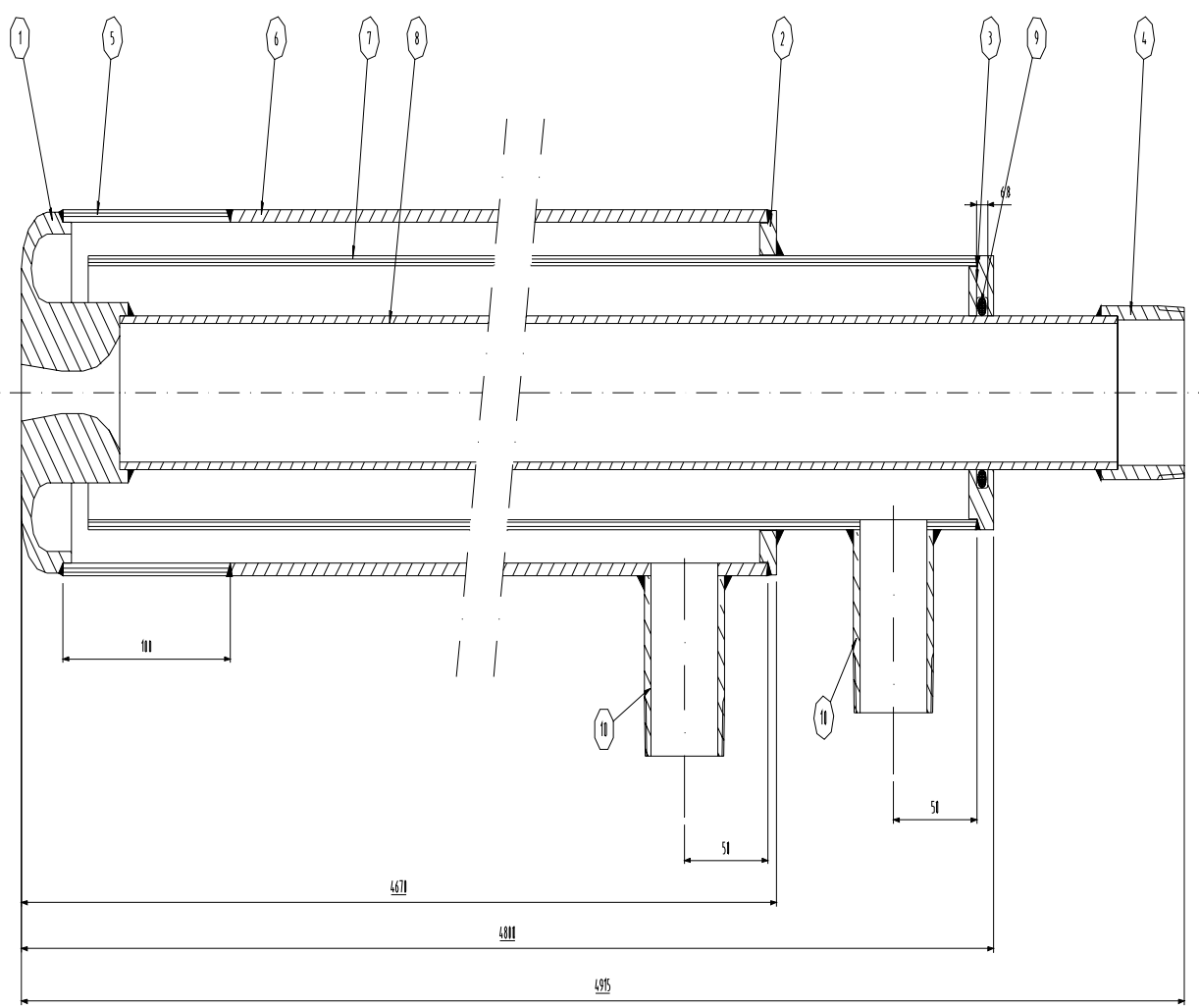

Figure 3 - Oxygen lance 


\subsubsection{Bottom purging tuyere}

Top blown converters suffer from low metal stirring resulting in low mass transport rates witch thereby sets a limit for material trough put. A simple and efficient solution is to install a gas purging element in the bottom of the converter. For the experiment a double eccentric pipe tuyere was selected for injection of nitrogen and hydrogen.

Technical data:

Length $\quad 700 \mathrm{~mm}$

Outlet slit, diameters $17,40-17,95 \mathrm{~mm}$

Nominal gas flow rate $0,5 \mathrm{~m}^{3} \mathrm{n} /$ minute 
-AI p14 -

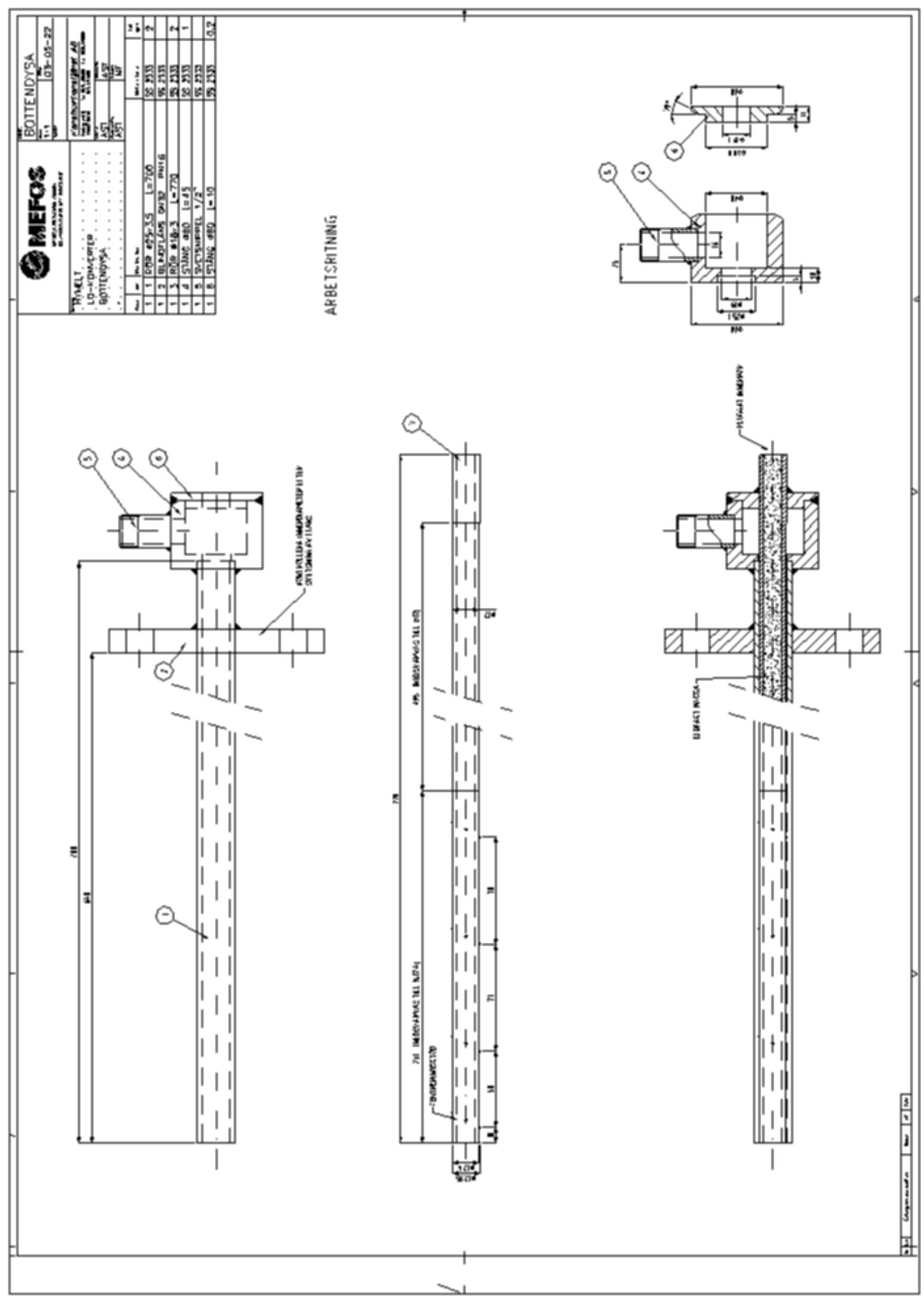




\section{-AI p15 -}

Figure 4 - Bottom tuyere

\subsubsection{Gas and dust sampling lance for converter atmosphere}

Process gas and dust was collected by a suction lance that could be lowered into the converter in parallel with the injection lance. The lance tip was made as an exchangeable ceramic probe of castable high alumina.

Technical data:

Length

3825

Diameter

$76 \mathrm{~mm}$ 
-AI p16 -
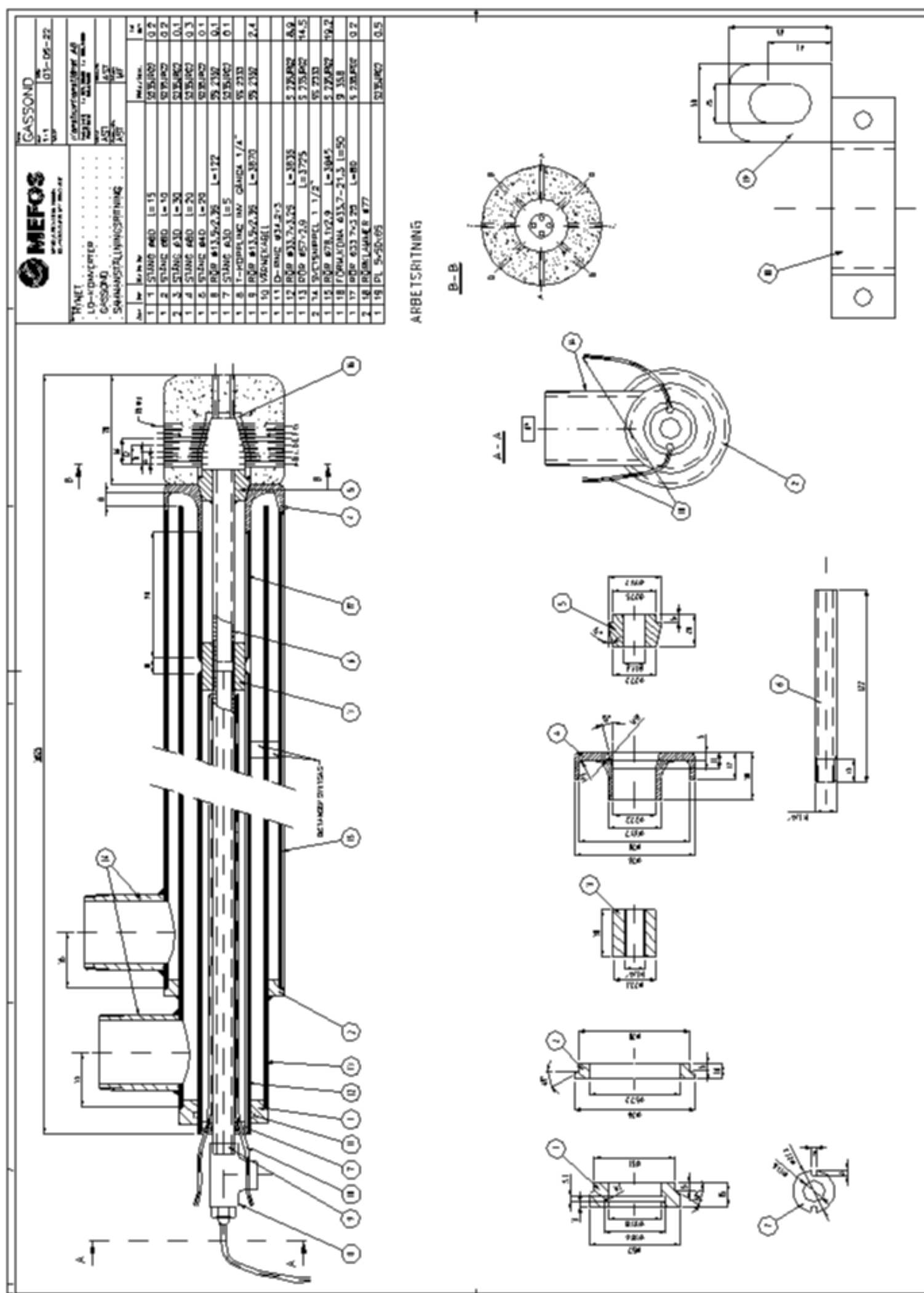
Figure 5 - Lance for gas sampling in converter

\section{Material}

\subsection{Injectants}

Materials used for the tests supplied by EnviRes.

\subsubsection{Illinois \#6}

$\begin{array}{ll}\mathrm{C} & 71,14 \% \\ \mathrm{H} & 4,91 \% \\ \mathrm{~N} & 1,48 \% \\ \mathrm{Cl} & 0,13 \% \\ \mathrm{~S} & 3,48 \% \\ \mathrm{O} & 8,26 \% \\ & \\ \mathrm{Ash}^{2} & 10,81 \% \\ \mathrm{SiO}_{2} & 50,65 \% \\ \mathrm{Al}_{2} \mathrm{O}_{3} & 20,15 \% \\ \mathrm{CaO} & 4,01 \% \\ \mathrm{Fe}_{2} \mathrm{O}_{3} & 16,25 \%\end{array}$

\subsubsection{Pet-Coke}

C $\quad 86,3 \%$

$\mathrm{H} \quad 5,0 \%$

$\mathrm{N} \quad 1,0 \%$

S $\quad 6,5 \%$

\subsubsection{Aromatic extract}

$\begin{array}{ll}\mathrm{C} & 90,31 \% \\ \mathrm{H} & 6,99 \% \\ \mathrm{~N} & 0,24 \% \\ \mathrm{~S} & 4,09 \%\end{array}$

\subsection{Additives}

Locally supplied material 


\subsubsection{Lime mix}

The slag former used was a pre mix of burned lime and burned dolomite in 9 to 1 ratio.

$\underline{\text { Lime }}$

Fraction $\quad 3-14 \mathrm{~mm}$

$\mathrm{CaO} \quad 92,5 \%$

$\mathrm{SiO}_{2} \quad 1,6 \%$

$\mathrm{MgO} \quad 1,4 \%$

LOI $2 \%$

$\mathrm{CO}_{2} \quad 1,5 \%$

Dolomite

Fraction $10-40 \mathrm{~mm}$

$\mathrm{CaO} \quad 58 \%$

$\mathrm{SiO}_{2} \quad 0,25 \%$

$\mathrm{MgO} \quad 40 \%$

$\mathrm{CO}_{2} \quad 0,25 \%$

\subsubsection{Aluminium bars}

Aluminium bars of $\sim 5 \mathrm{~kg}$ were used as fuel additives for compensation of the heat balance. The addition was made before start of oxygen blowing.
Al $\quad 96,57 \%$
Si $\quad 0,62 \%$
$\mathrm{Mg} \quad 1,41 \%$
$\mathrm{Fe} \quad 0,65 \%$

\subsubsection{Ferro silicon}

Ferro silicon was used as fuel additives for compensation of the heat balance. The addition was made before start of oxygen blowing.

$\mathrm{Si} \quad 92 \%$

\subsubsection{Ferro sulphur}

Ferro sulphur was used in the last heat S1787 in order to drastically increase operational sulphur level in slag and metal. The test included purging of hydrogen through bottom the tuyere.
S $\quad 29,18 \%$
P $\quad 0,01 \%$
C $\quad 0,047 \%$ 


\subsubsection{Ferro vanadium}

In order to indicate the material balance for vanadium the concentration of vanadium was increased in the last heat S1787.

$\begin{array}{ll}\mathrm{V} & 81,88 \% \\ \mathrm{C} & 0,016 \% \\ \mathrm{~S} & 0,023 \% \\ \mathrm{Si} & 1,23 \% \\ \mathrm{Al} & 0,46 \% \\ \mathrm{P} & 0,016 \%\end{array}$

\section{Test procedure}

\subsection{Melting}

Charging of pig iron was made the day before the test. The melting procedure followed standard routines for production of synthetic hot metal, $\sim 4 \% \mathrm{C}$ and $\sim 0,2 \% \mathrm{Si}$. Before tapping to a hot metal transfer ladle, the temperature was adjusted to $\sim 1600{ }^{\circ} \mathrm{C}$.

\subsection{Decarburisation of hot metal}

The converter operation started with oxygen blowing, $10 \mathrm{~m}^{3} \mathrm{n} / \mathrm{min}$, to $\sim 1650{ }^{\circ} \mathrm{C}$. During blowing, about 20 minutes, all silicon and some carbon from the metal were oxidised. To maintain a slag with reasonable fluid ability and melting temperature, the formed $\mathrm{SiO}_{2}$ was neutralised by the double amount of lime mix. The lime mix consisted of $90 \%$ burned lime and $10 \%$ burned dolomite.

The oxygen lance and lime feed program was simplified to:

\begin{tabular}{|c|c|c|}
\hline Time & Operation & Lance position above metal surface \\
\hline $0 \min$ & Ignition & $400 \mathrm{~mm}$ \\
\hline $1 \mathrm{~min}$ & Lime feed & $800 \mathrm{~mm}$ \\
\hline $3 \mathrm{~min}$ & 600 & \\
\hline
\end{tabular}

During blowing the metal temperatures were measured and samplings were made approximately every second minute. The samples taken were analysed for $\mathrm{C}$ and $\mathrm{S}$ by use of a Leco analyser.

\subsection{Carburisation $\mathrm{H}_{2}$ production}

The oxygen blowing was followed by carburisation and $\mathrm{H}_{2}$ production. The operation was made by top lance injection, $\sim 10 \mathrm{~kg} / \mathrm{min}$, at a distance of about $400 \mathrm{~mm}$ above the metal surface. Temperature measurements and sampling were made as for oxygen blowing. The operation was stopped when desired carbon content was achieved or if the metal temperature became too low. 
During blowing a probe for gas sampling was lowered into the converter, $700 \mathrm{~mm}$ above metal surface. The sampled gas was analysed for $\mathrm{CO}, \mathrm{CO}_{2}, \mathrm{H}_{2}, \mathrm{H}_{2} \mathrm{~S}$, $\mathrm{COS}$, and $\mathrm{CH}_{4}$. Alternatively the sampled gas was collected in a liquid for later $\mathrm{Hg}$ analysis. A filter, placed back of the lance, was changed after each blowing period and the collected dust was saved for later analysis. Dust sampling was also made by isokinetic suction from combusted gas in the off gas duct.

After the injection period the converter was tilted and the slag and metal could be inspected and sampled. The metal samples were of spectrometer quality for full chemical determination. If necessary some slag was skimmed of.

\subsection{De-carburisation CO production}

The procedure for de-carburisation followed mainly the routines for classical BOF blowing. Compensation for heat losses were made by addition of additional fuel, aluminium bars and $\mathrm{FeSi}$ before blowing start. To maintain reasonable slag properties the formed $\mathrm{Al}_{2} \mathrm{O}_{3}$ and $\mathrm{SiO}_{2}$ was compensated by lime mix.

The procedure was followed by a new injection period or by tapping in case of the last trial for the day.

\subsection{Tapping}

Before tapping the metal temperature was adjusted to about $120^{\circ} \mathrm{C}$ super heat. This was made by oxygen blowing in combination with scrap or aluminium addition. After slag skimming, tapping was made into a steel ladle or hot metal ladle and cast into sand beds. The following day slag and metal was separated and weights were recorded. 


\section{Heat notes}

\subsection{HyMelt 1}

Un-alloyed pig iron was melted in the EAF, tapping and charging of $5500 \mathrm{~kg}$ of hot metal was made without only small disturbances.

\section{Heat ID S1782}

Coal was selected for injection.

Totally five period of injection were made and initial problems were detected on:

- Level control of the lances had a poor function because of mechanical interference between cooling rubber tubes and malfunction of chain for the oxygen lance

- Sub-lance system had to be tuned for dipping time and sampling level

- $\mathrm{O}_{2}$ flow-rate control and routines for the MEFCON system had to be tuned

- The dust load indicated that the complete system for process gas had to be cleaned after each injection period.

- The temperature drop during injection was unexpected high about $10{ }^{\circ} \mathrm{C}$

- Low temperature injection $<1400^{\circ} \mathrm{C}$ gave "unreacted coke" on top of the slag

Tapping and casting could be made without any problems.

New routines for data collection and conducting the test must be made for the coming day.

\subsection{HyMelt 2}

\section{Heat ID S1783}

Operation could be performed under good control. Totally five periods of coal injection and one period of coke were made.

- The "unreacted coke" on top of the slag could almost be completely avoided by operation at higher temperatures, melt temperature was maintained above $1400^{\circ} \mathrm{C}$.

- The poor heat balance was managed by aluminium addition and by avoiding tilting of the converter between oxygen blowing and injection.

- 4 periods of process gas sampling was possible.

- 2 gas analysis coal injection

○ 1 Hg-sampling coal injection

- 1 gas analyse coke injection

- From the start of gas suction the pressure drop increased giving a continuously increased amount of leakage air to the analysers. 
- Sculling, narrowing the converter mouth gave some problems with lance movements

- The last injection was made with coke giving strong indications of an improved carbon yield and an improved heat balance.

- The feeding rate was reduced during coke injection. It was later found that some rubber material was blocking the outlet.

\subsection{HyMelt 3}

\section{Heat ID S1784}

Pet-coke was used for all injections periods. Totally five periods was made and gas suction of process gas was possible for all periods. An overall improved heat balance gave drastically reduced aluminium addition. This in combination with no ash in the material gave a low slag trough put and a stiff and dry slag. It was understood that the slag has been saturated with $\mathrm{MgO}$ from refractory wear during the day.

Moderate feed rate $10 \mathrm{~kg} / \mathrm{min}$ gave in first two injection periods excellent result. Attempt to increase the rate up to $20 \mathrm{~kg} / \mathrm{min}$ was only possible by reducing the carrying gas from $0,55 \mathrm{~m}^{3} \mathrm{n} / \mathrm{min}$ to $0,35 \mathrm{~m}^{3} \mathrm{n} / \mathrm{min}$ and by increasing the nozzle outlet diameter from 7,0 to 7,5 $\mathrm{mm}$ at $\sim 12: 00$. Both these action caused a lower impulse of material jet to the bath. It was later found that coal was by mistake charged to the dispenser during the day.

- Large amount of coke was trapped in the slag giving flames spontaneously or when the slag was skimmed.

- The dry slag gave problems to measure in blow temperatures.

- The heat was tapped when water leakage occurred on the oxygen lance.

- Remaining problem with increased amount of leakage air during sampling of process gas. The analysed components must be corrected by use of an oxygen balance. Argon content is therefore included from this day in the database. Clogging is mainly caused by dust in the filter in top of the lance and in the ceramic head.

- The standard hydrogen analyser was closed before the start of the tests.

- Recalibration of MS hydrogen was made after that calibration gas of $100 \%$ responded only $85 \%$. Can be seen in the data base.

\subsection{HyMelt 4}

\section{Heat ID S1785}

Pet-coke injection was made for 5 periods, gas analysis was possible for all. During the day the confusion between coal and pet-coke was detected. 
A new slag was tested, the purpose was to achieve good fluid ability down to $1400^{\circ} \mathrm{C}$. The slag was made of oxides from FeSi98 and aluminium bars fluxed with lime and dolomite mix. The result was acceptable and slag skimming could be made after the injections.

The injection nozzle was drilled to $8 \mathrm{~mm}$ to allow higher feeding rate up to $20 \mathrm{~kg} / \mathrm{min}$. However at this rate the transport gas had to be lowered to $0,3 \mathrm{~m} 3 \mathrm{n} / \mathrm{min}$ giving a lower impulse from the gas/material jet into the melt. This was during the day compensated with higher gas flows $0,7 \mathrm{~m}^{3} \mathrm{n} / \mathrm{min}$ and a lower material flow rate.

The operational lance distance was measured with a steel bar placed on the material lance nozzle. The result confirmed calibration $400 \mathrm{~mm}$ indicated metal up to $280 \mathrm{~mm}$. The difference is caused by unstable metal surface from bottom stirring.

Preliminary mass balance shows low carbon yield to the melt, the losses to combusted gas was typically $3 \mathrm{~kg} / \mathrm{min}$ and coke in the slag was found in the same magnitude. $\mathrm{High} \mathrm{CH}_{4}$ $\%$ was also reported from process gas analysis.

Sculling on the oxygen lance was detected for the first time and had to be cleaned several times. It was also found that the nozzle of the material lance was clogged in home position during oxygen blowing. It was easily detected when carbon injection was started with the material plume in the slit between converter mouth and the hood. This small scull was removed before all tests except from the first injection which was operated with a poor plume.

The moderate carbon yield can be caused by:

- Particles not solute directly in the jet-metal interface will float up on slag surface giving only small possibilities to contact with metal. With a stiffer slag it is more likely that metal surface and coal particles in direct contact.

- Lower jet impulse from the larger nozzle diameter.

Later note: material confusion caused the main problems with C-yield.

\subsection{HyMelt 5}

\section{Heat ID S1786}

Injection of oil was made for the first 4 periods, the remaining day coal was injected for 3 periods. Oil seems to be a more difficult source than solids. Large amount of $\mathrm{CO}_{2}$ was detected in the combusted gas indicating severe soot formation.

The coal tests showed similar results as previous heats, moderate carbon yield, tendency for build up of coal on top of slag and a weak heat balance. The lance was made with a 7 mm nozzle. 
At 14:30 it was discovered that one of the coke bags was confused with coal. Until then coal has been injected as coke. This can explain the problems to repeat the good results achieved earlier with coke. Experiments made at HyMelt 4 must be rechecked.

Good gas suction of process gas for analyse. The last two periods was used for mercury sampling.

\subsection{HyMelt 6}

\section{Heat ID S1787}

Totally 6 injection periods with pet-coke were made at controlled conditions.

Tests at higher $\mathrm{V}$ and $\mathrm{S}$ levels.

Hydrogen purging at high sulphur level was performed

\section{Result}

The complete data base and the individual test periods have been distributed separately. Below is supplementary data presented as graphs. Detailed information on individual test periods can be found in Appendix 1.

\subsection{Process gas analysis}

In Appendix 2 is an overview of measured components in the process gas presented. Detailed graphs for individual injection periods are presented separately and comments made do also refer to those.

A general difficulty was clogging of the sampling probe giving an increased amount of leakage air in the gas sample during the measuring periods. For the evaluation the recorded values have been balanced by use of the measured oxygen for compensating the amount of air dilution

Isolated peak values are related to calibration and frequent peaks especially on $\mathrm{CO}$ are caused from partial combustion of sub-lance probes.

\subsubsection{CO}

The recordings show significant difference between the injectants.

- Coal gives stabile CO concentration in the range of $20-30 \%$.

- Coke gives a decreasing CO concentration during injection starting around 20\% down to $10 \%$.

- Oil shows the same behaviour as coke but on a lower CO concentration down below $5 \%$.

The measurements seem to mirror the oxygen content in the material and that we have to consider declining reduction of oxides in the slag during injection. 


\subsection{2 $\mathrm{CO}_{2}$}

It is not expected to have significant amount of $\mathrm{CO}_{2}$ in the process gas. The presence can be due to leakage air into the converter atmosphere or to leakage in the sampled volume. The readings are generally below $5 \%$ and frequently below $1 \%$.

\subsection{3 $\mathrm{H}_{2}$}

The $\mathrm{H}_{2}$ measurement has a long response time, up to 5 minutes when calibration with a fixed concentration and it is accordingly to be expected an increased reading during the injection period. Coal and coke generates a gas of $50 \%$ to $60 \% \mathrm{H}_{2}$, occasionally $10 \%$ higher or lower, while oil shows about $70 \% \mathrm{H}_{2}$.

\subsection{4 $\mathrm{CH}_{4}$}

Coal and coke give gases of 5 to $7 \% \mathrm{CH}_{4}$ while oil gives 8 to $12 \%$.

The accuracy is not perfect since the component gives a stronger signal than recommended for optimal performance.

\subsection{5 $\mathrm{H}_{2} \mathrm{~S}$}

The process gas has a content of 0,2 to $0,4 \% \mathrm{H}_{2} \mathrm{~S}$ independent of injectant. At higher sulphur level in metal the $\mathrm{H}_{2} \mathrm{~S}$ content in the gas is somewhat higher, $0,5 \%$. $(0,8$ to $1,0 \% \mathrm{~S}$ compared to normal level 0,1 to $0,3 \% \mathrm{~S}$ )

It has not been shown that purging with $\mathrm{H}_{2}$ will effect the $\mathrm{H}_{2} \mathrm{~S}$ concentration.

\subsubsection{COS}

The graphs shown in the Appendix 2 are based on the spectrometer data base, since the records in the Lab View system do not mach. Unexpected high values have been measured, frequently more than $500 \mathrm{ppm}$, more typical recordings are in the range 100 to 300 ppm.

The data base in the spectrometer operates with complete different format and it is preferred if all future measurements are transferred to the Lab View system.

\subsection{7 $\mathrm{O}_{2}$}

No oxygen is expected to be in the gas, the presence is most likely due to leakage into the cooled gas sample.

\subsection{Metal analysis}

Below are the metal analysis presented for each element of interest. The analyses are generally believed to be good enough for the coming campaigns. However, the in-blow 
samples of spectrometer quality are few and the sampling procedure must be improved. Carbon and sulphur were analysed on the Leco system which operates with samples of lower quality.

Complete analysis of metal and slag is shown in Appendix 3 


\subsubsection{Carbon}

S1783

$\mathrm{S} 1783 \% \mathrm{~S}$ in metal

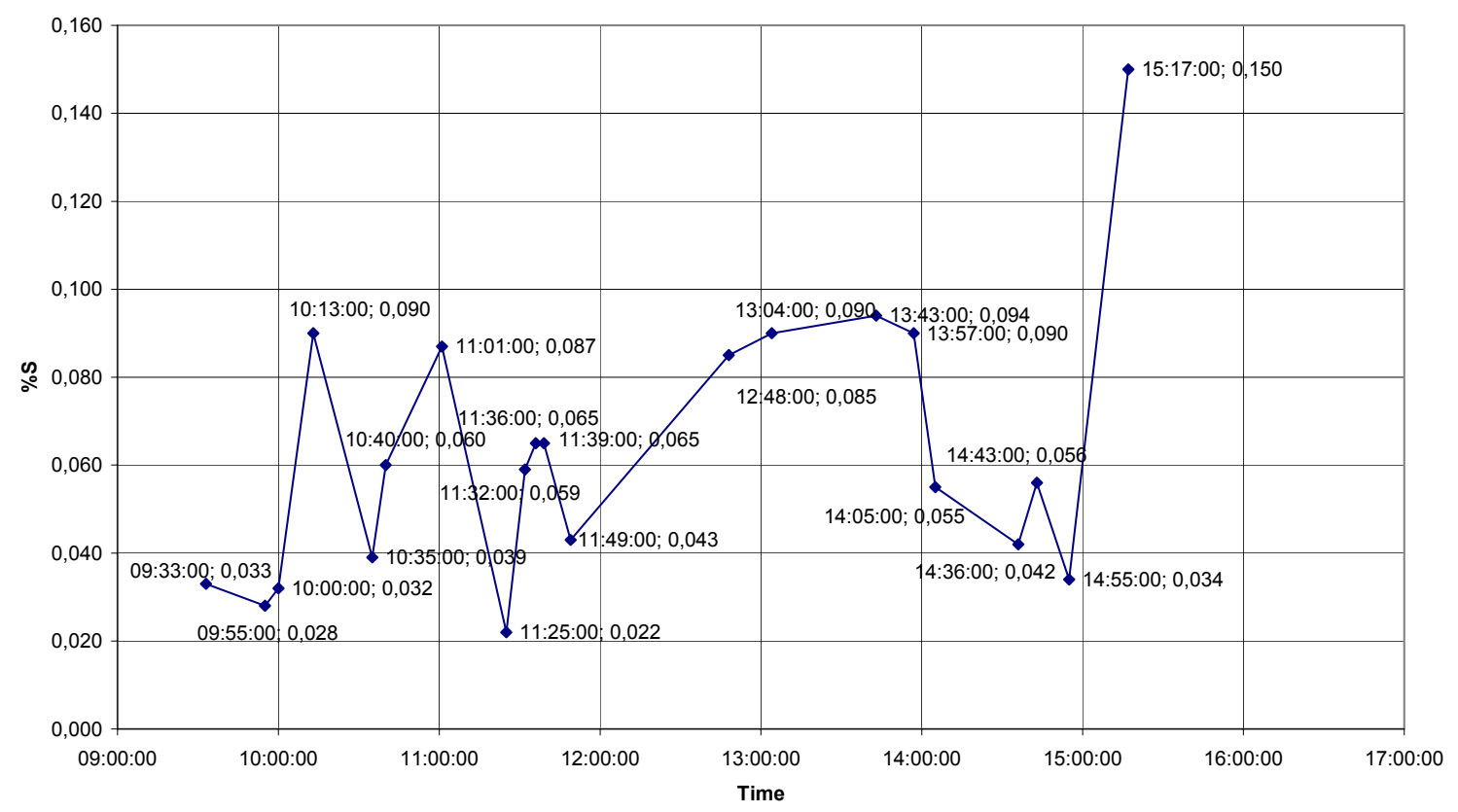

S1784 \%C in metal

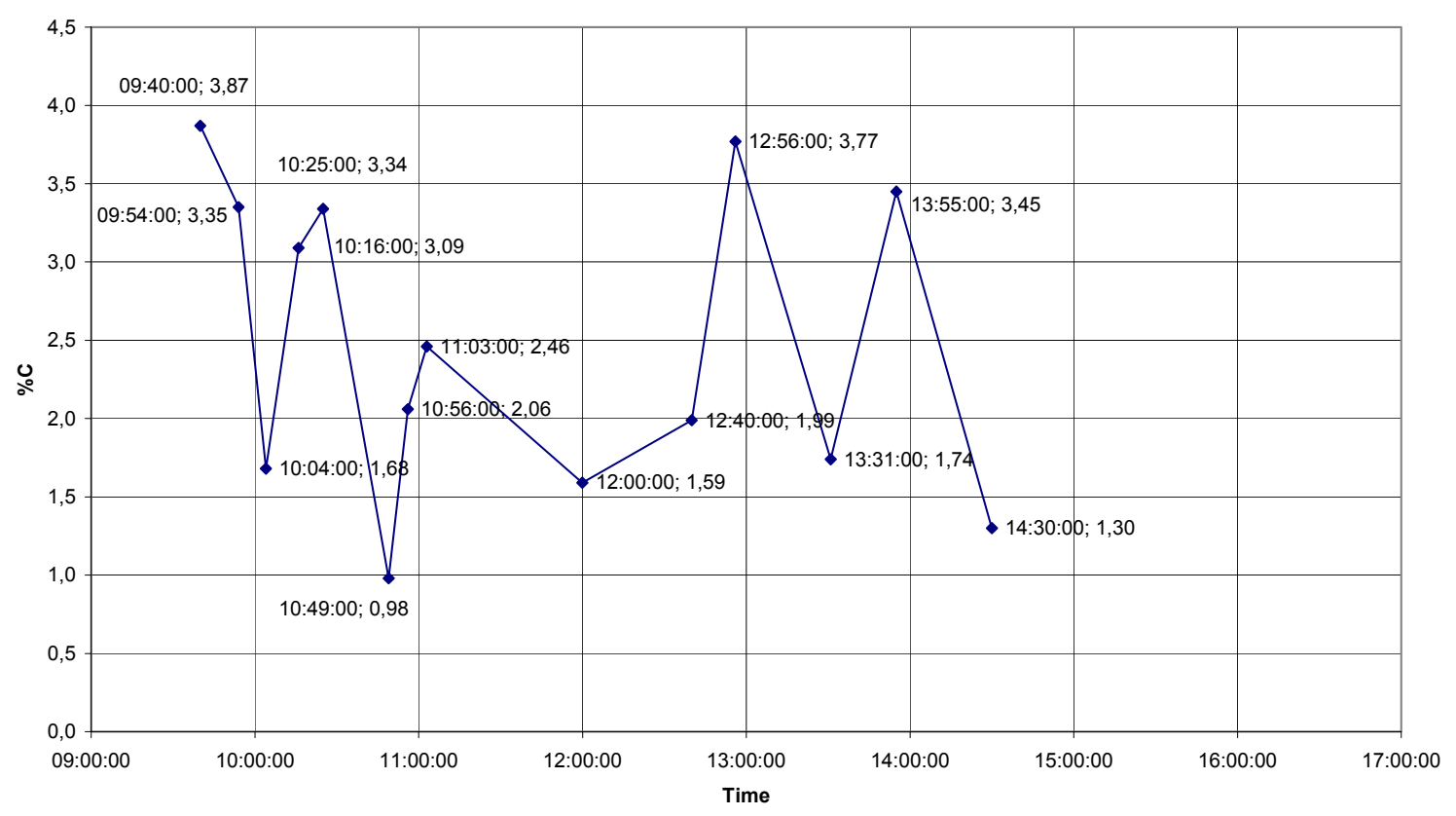


-AI p28 -

$\mathrm{S} 1785 \% \mathrm{C}$ in metal

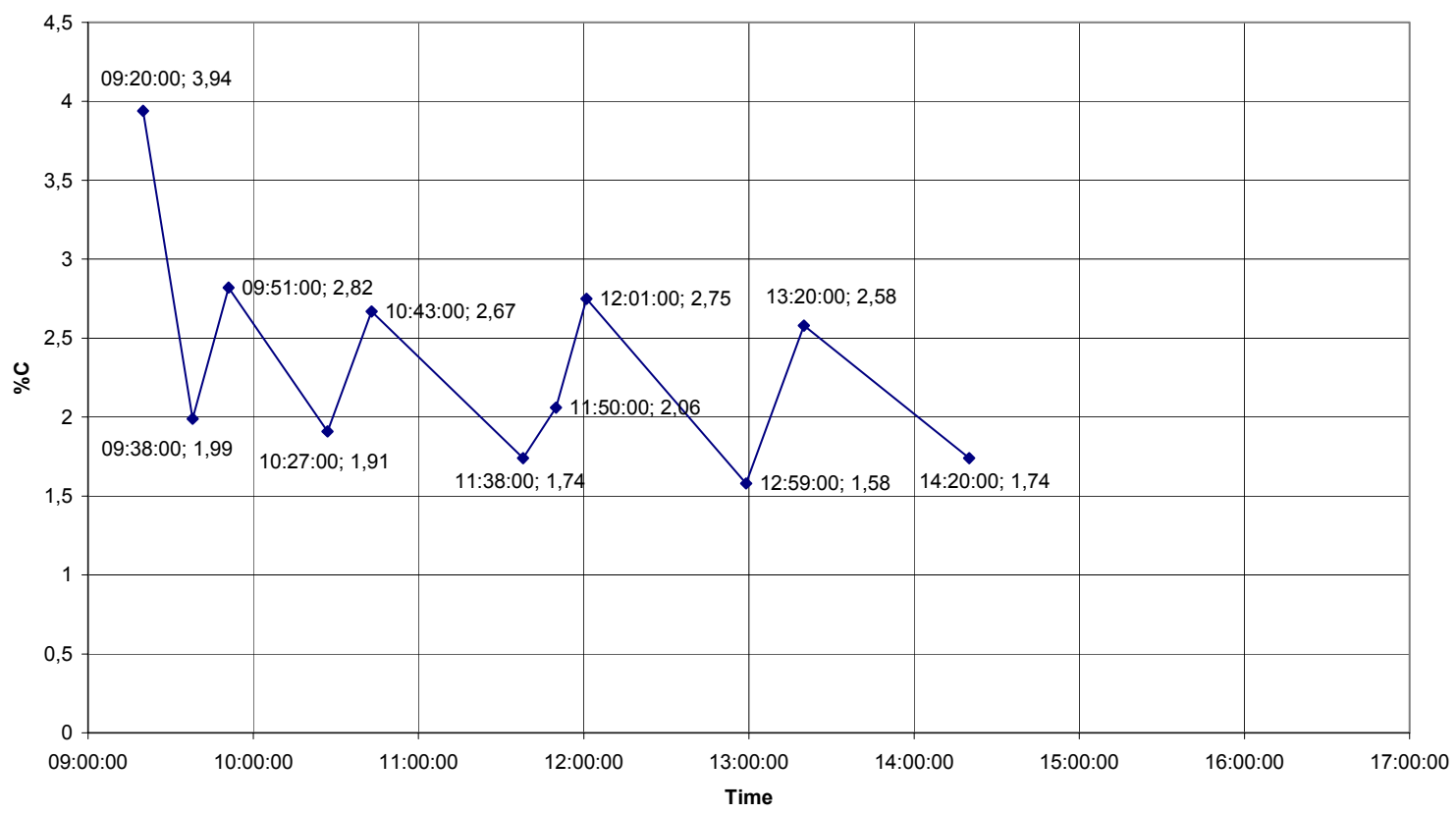

S1786 \%C in metal

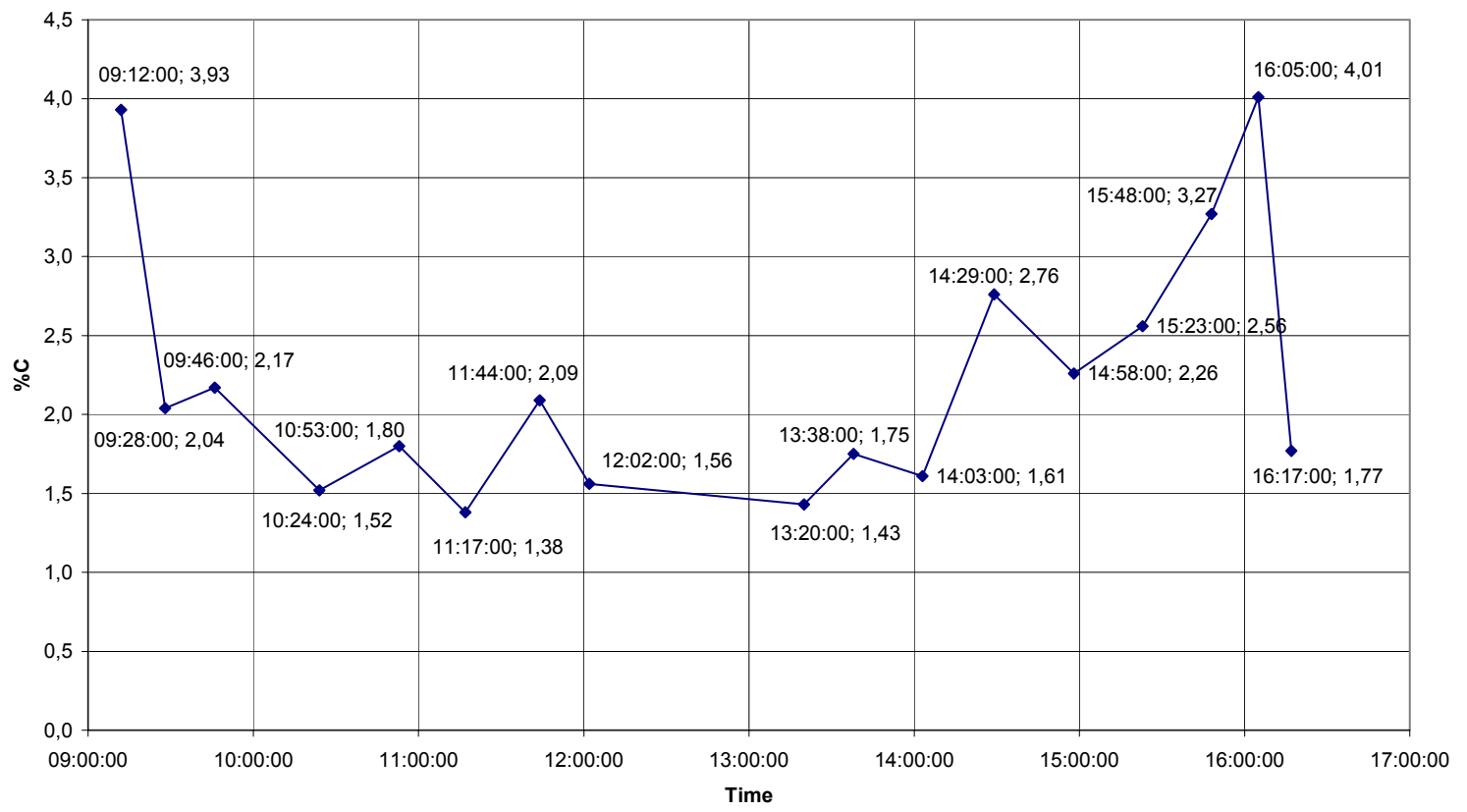


-AI p29-

$\mathrm{S} 1787 \% \mathrm{C}$ in metal

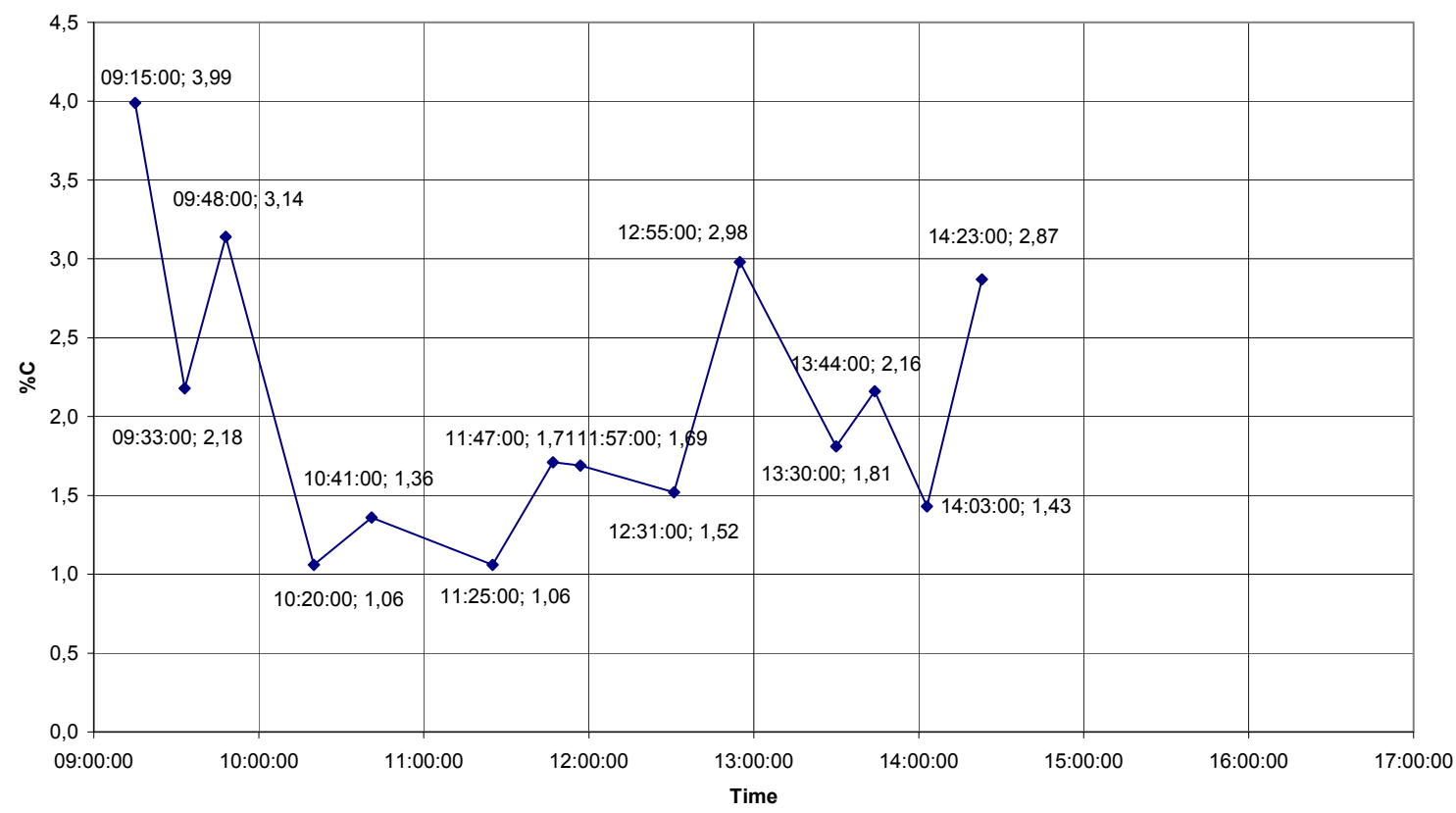

Figure $6-\mathrm{C}$ analysis in liquid metal HyMelt 2 to 6

\subsubsection{Sulphur}

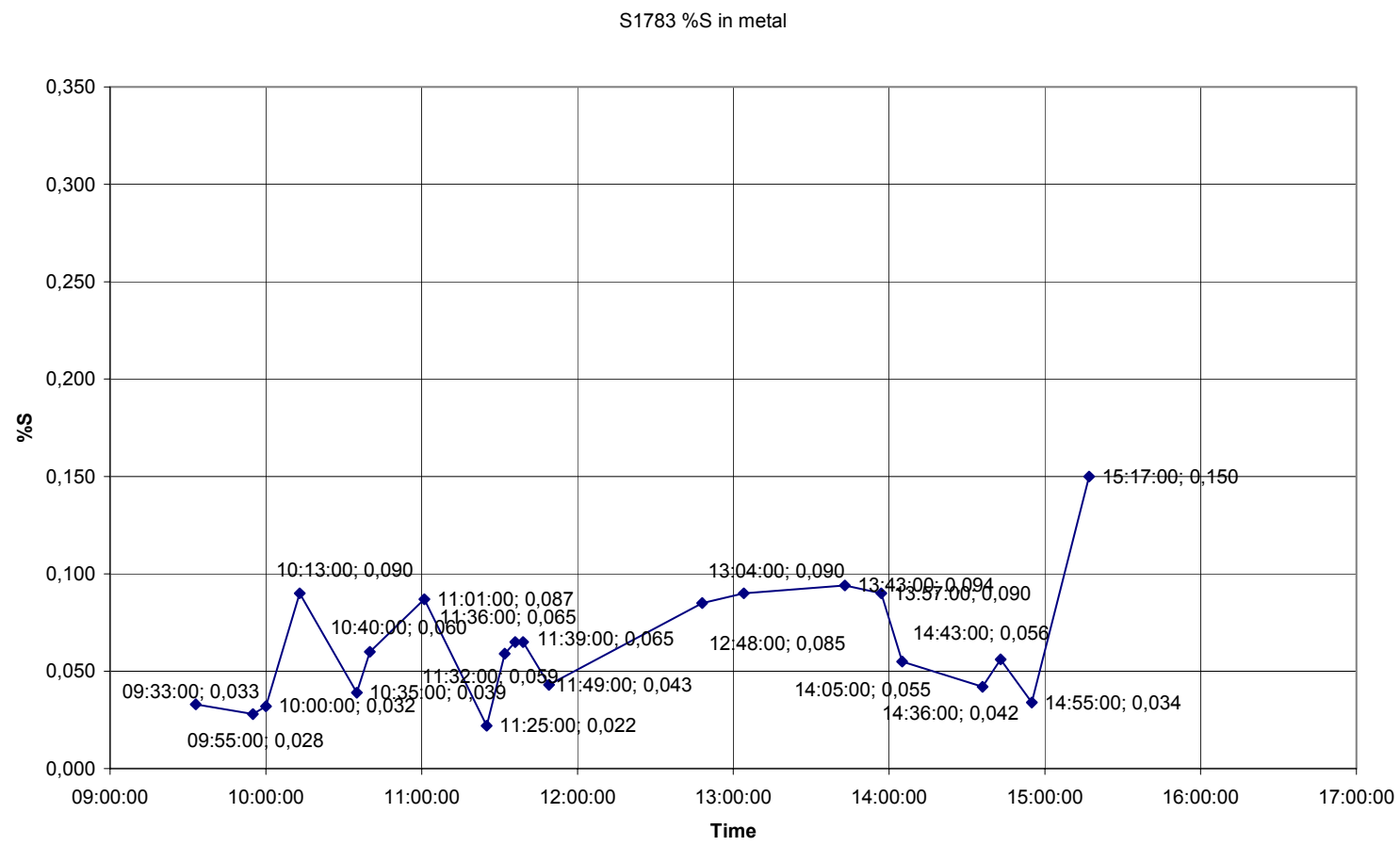


-AI p30 -

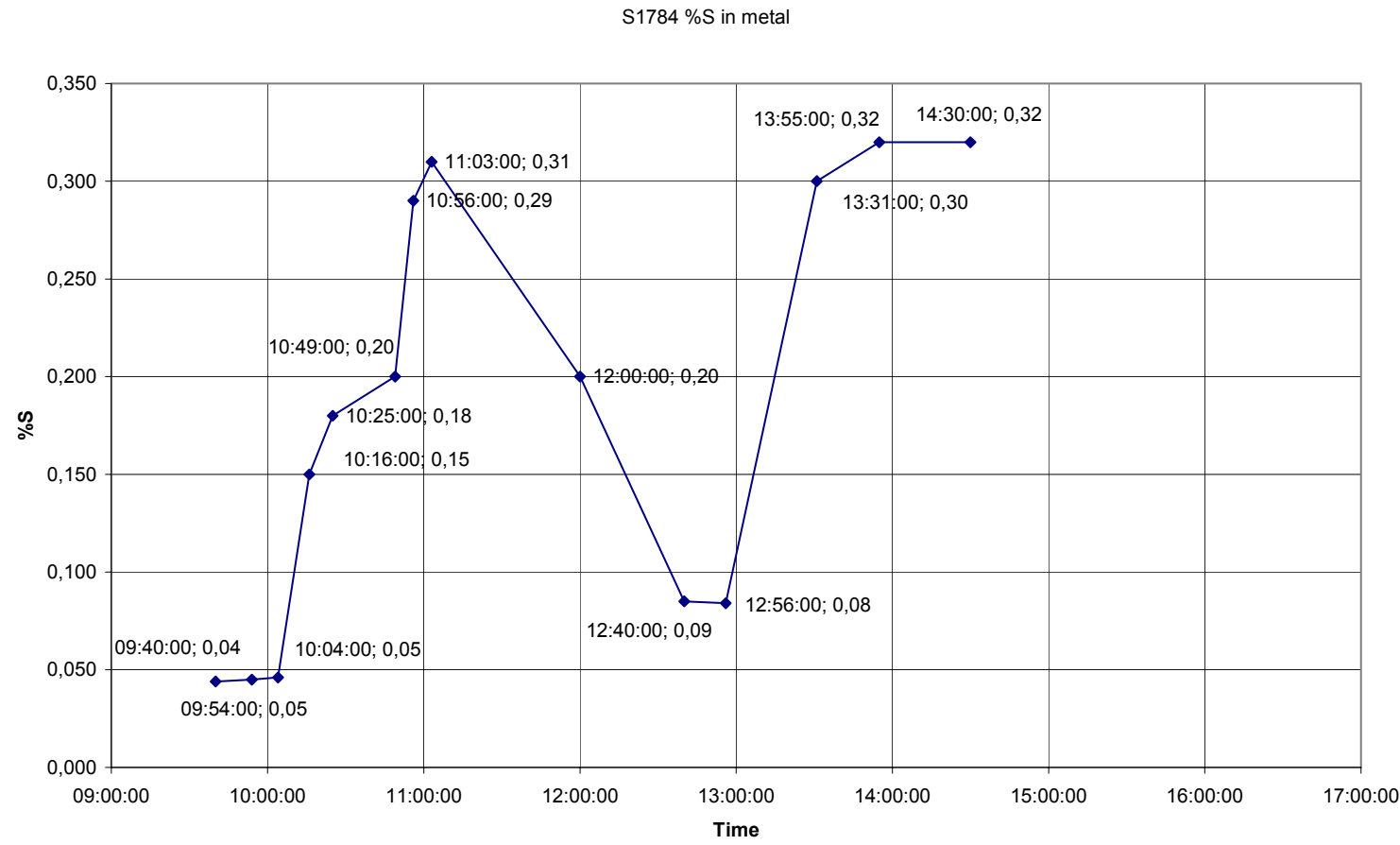

S1785 \%S in metal

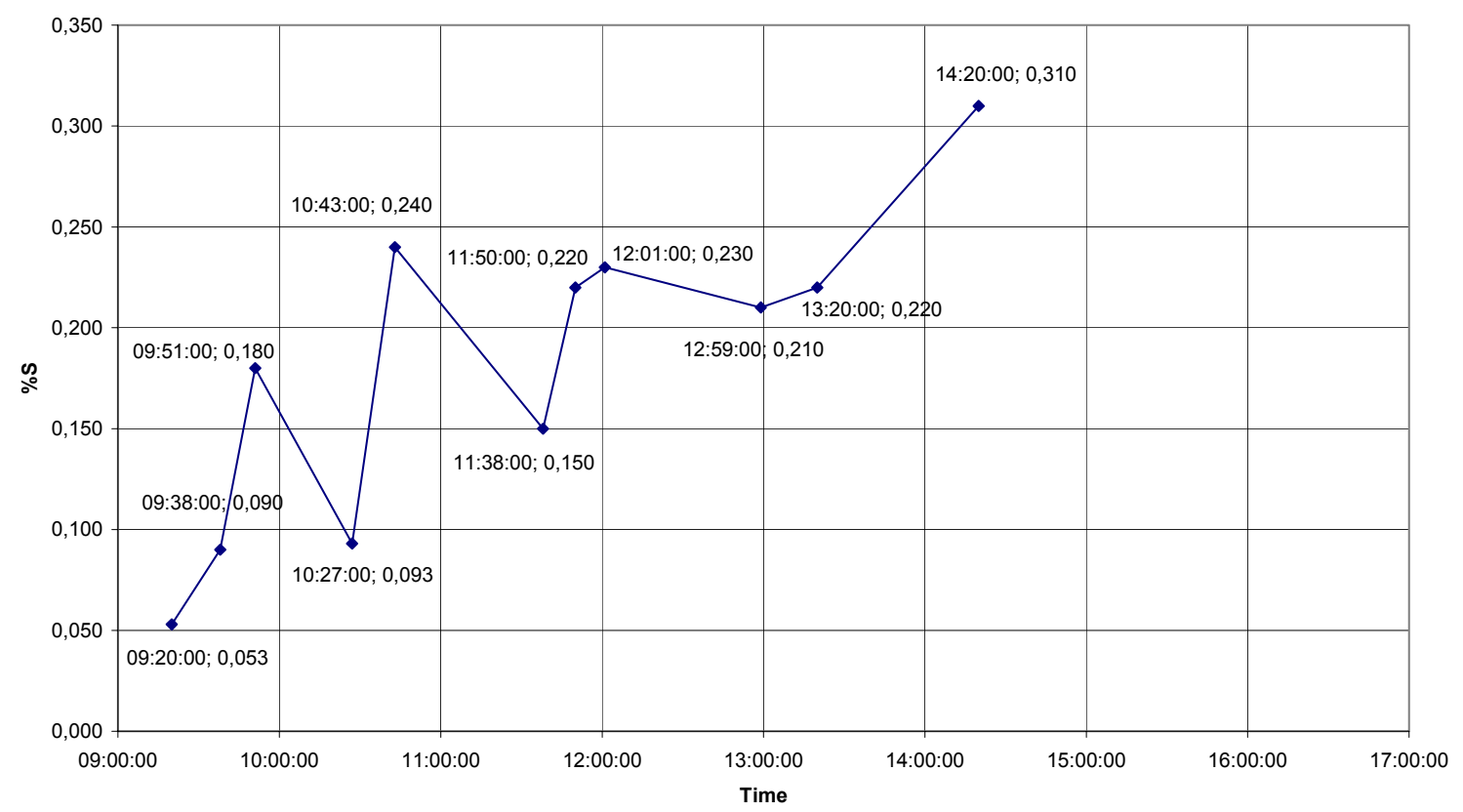


-AI p31 -

S1786 \%S in metal

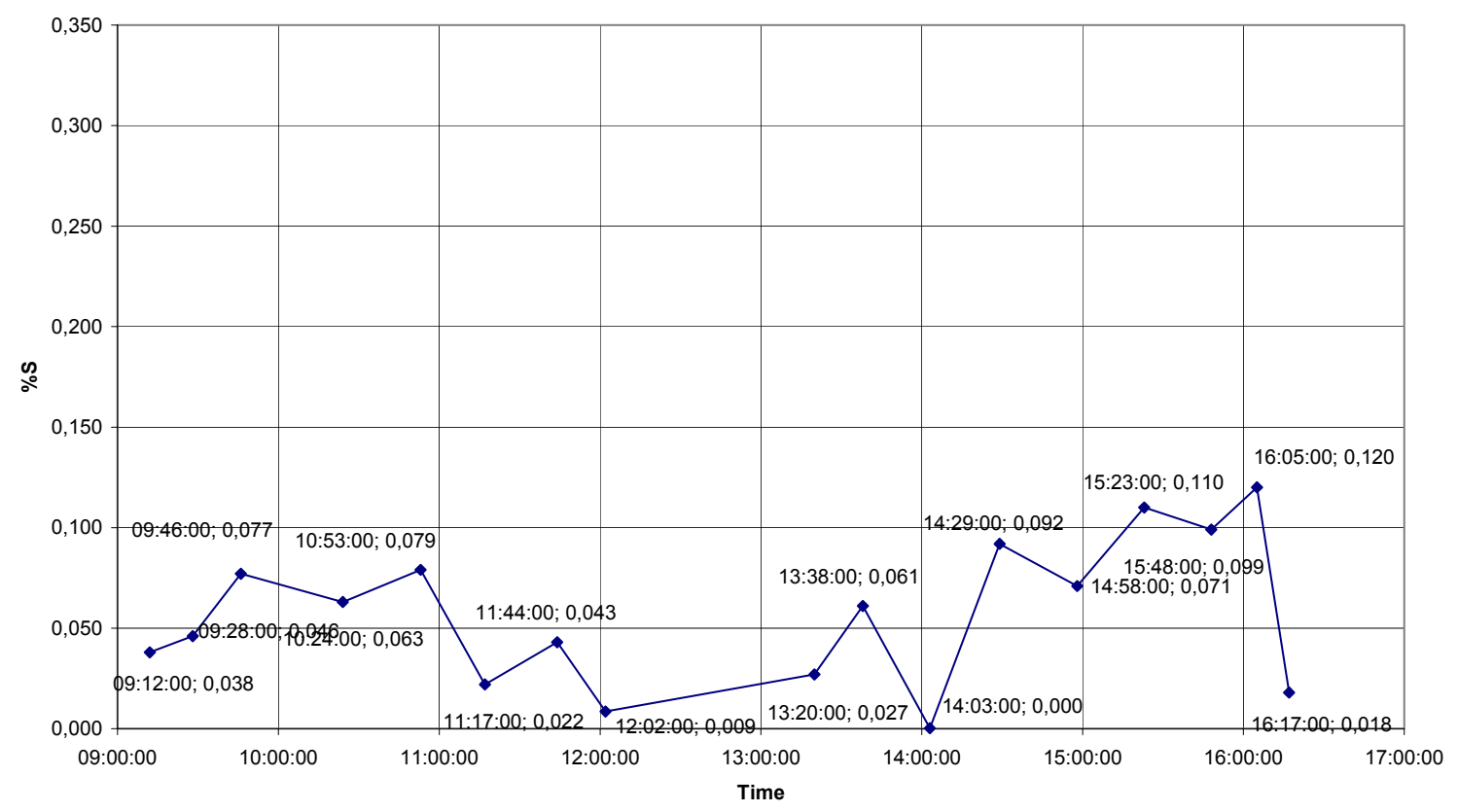

S1787 \%S in metal

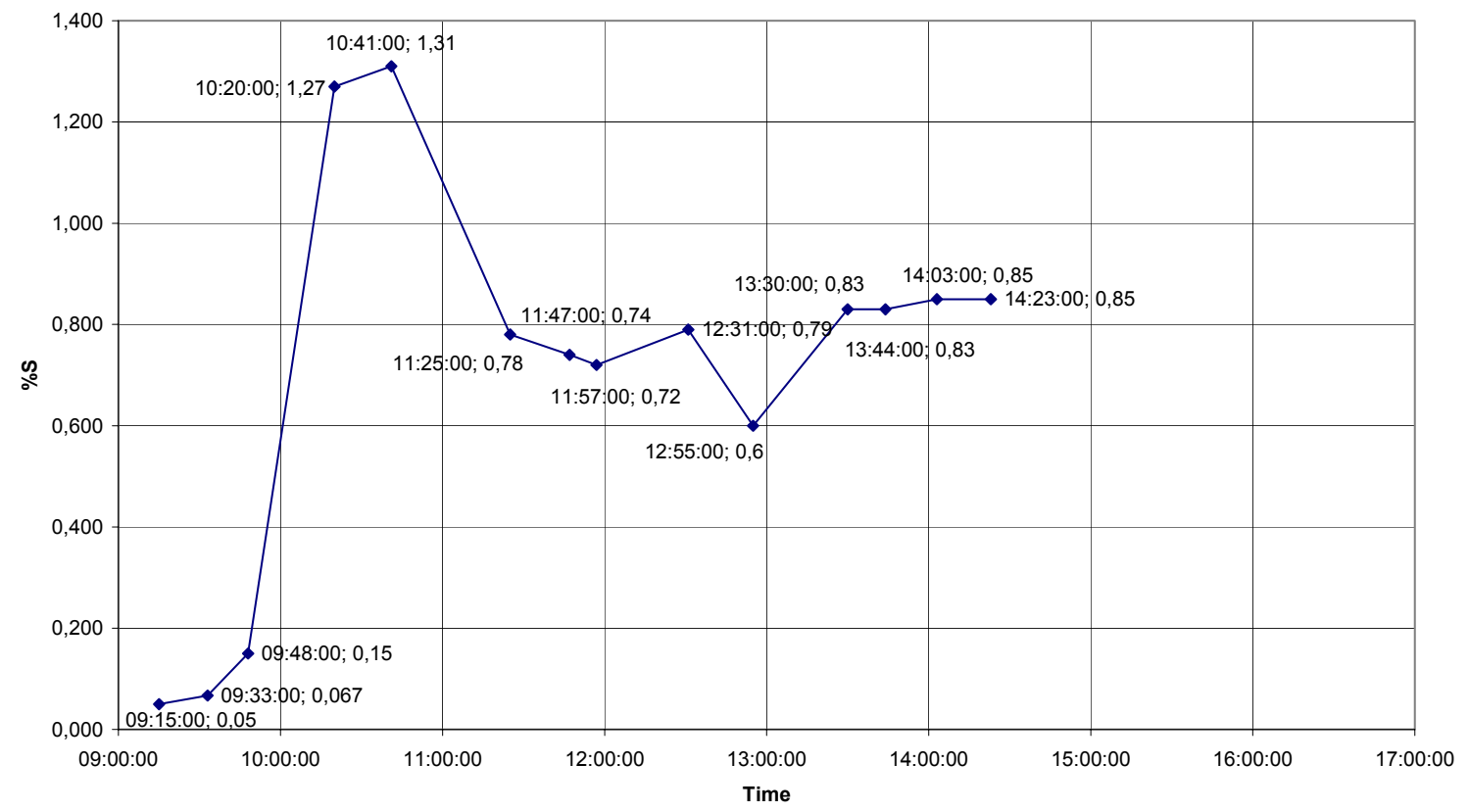

Figure $7-\mathrm{S}$ analysis in liquid metal HyMelt 2 to 6 
-AI p32 -

\subsubsection{Vanadium}

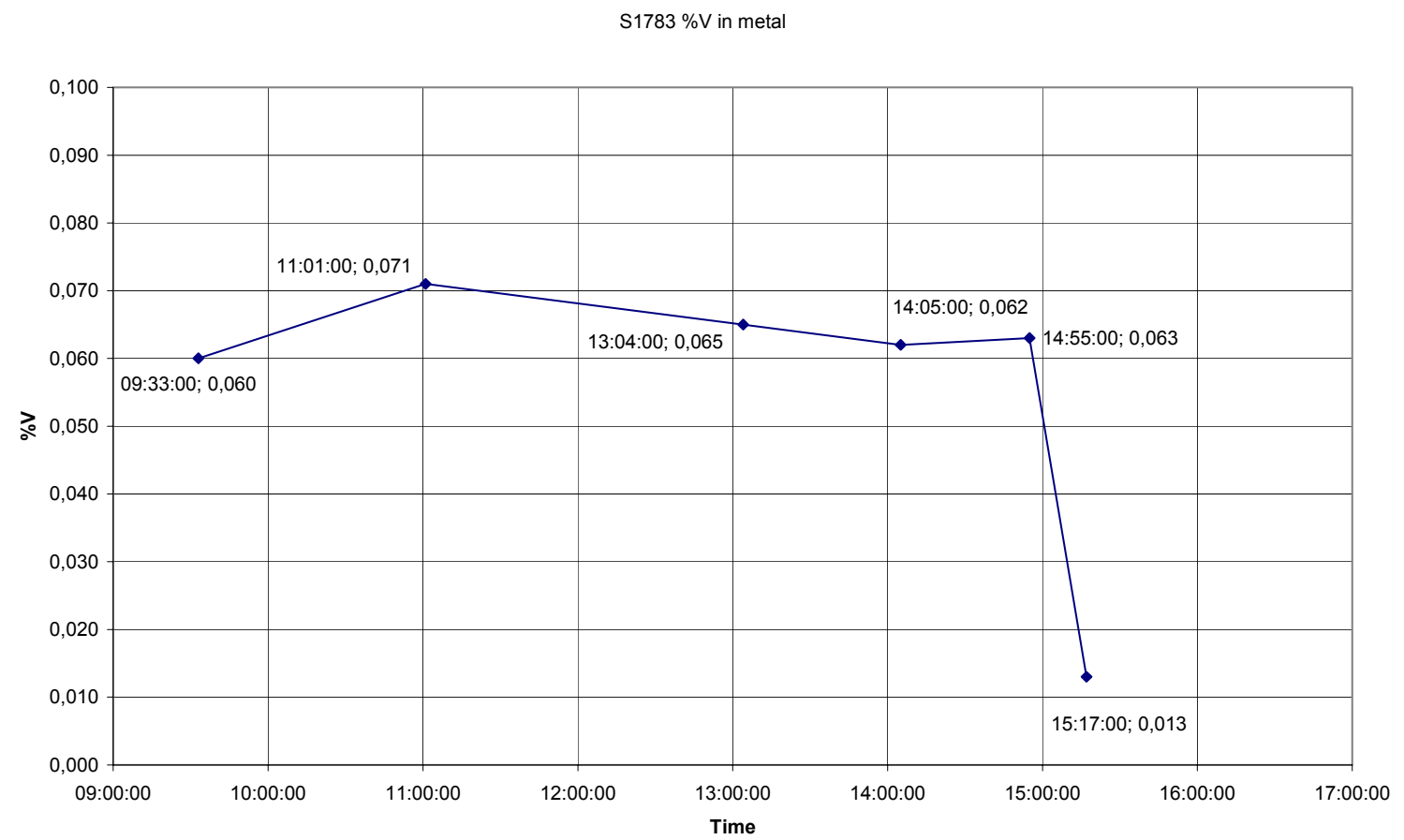

$\mathrm{S} 1784 \% \mathrm{~V}$ in metal

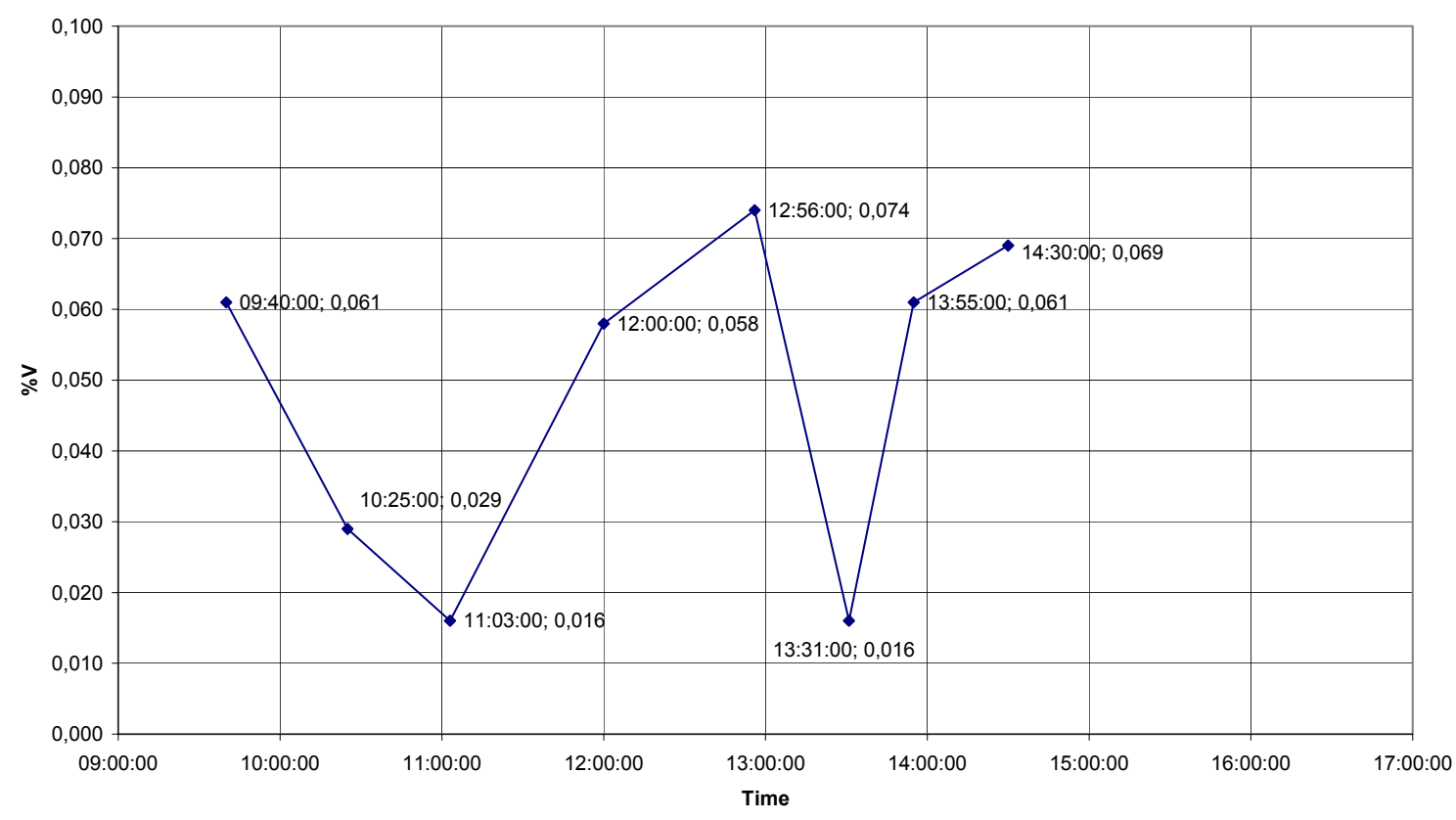


-AI p33 -

$\mathrm{S} 1785 \% \mathrm{~V}$ in metal

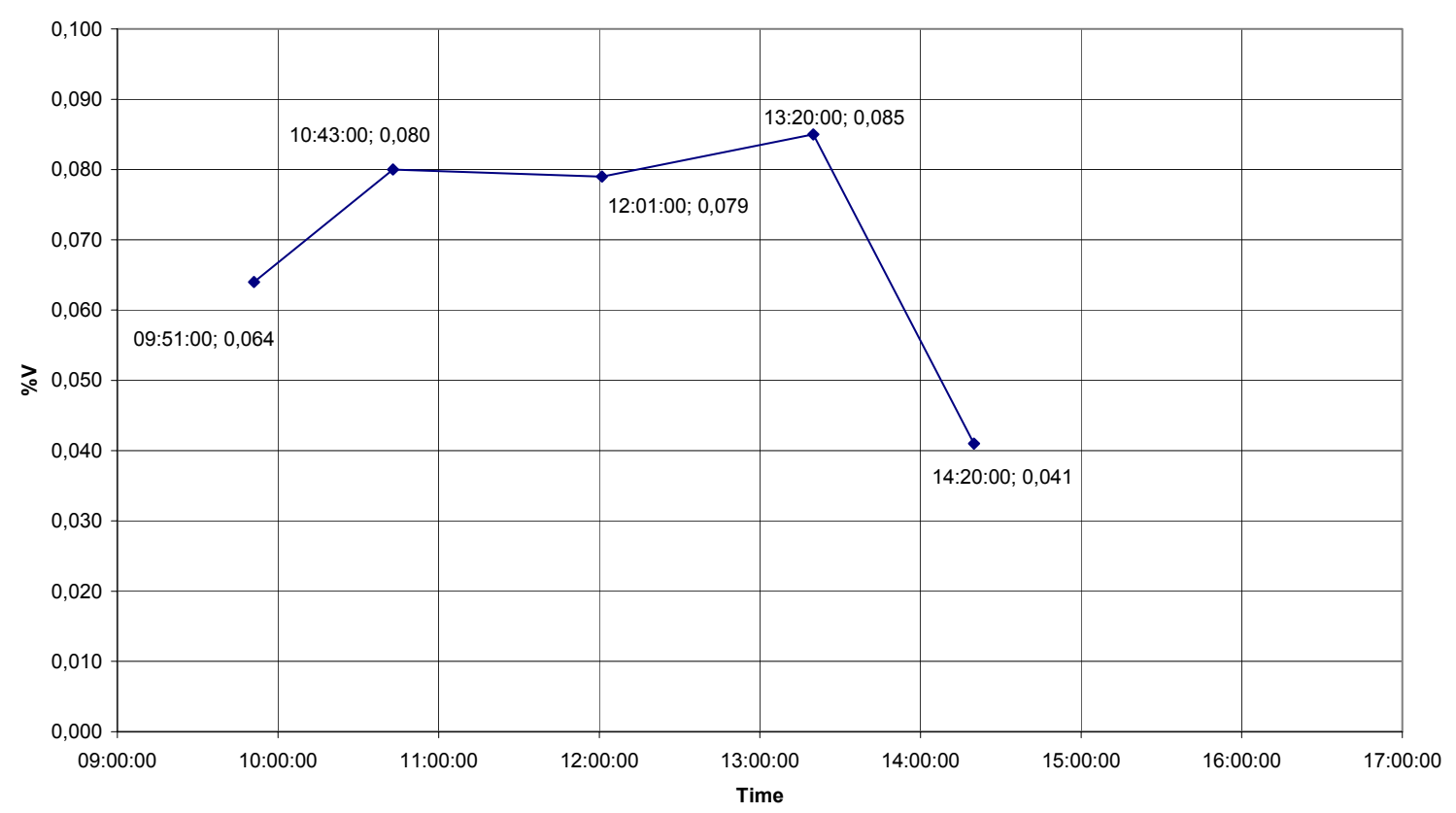

$\mathrm{S} 1786 \% \mathrm{~V}$ in metal

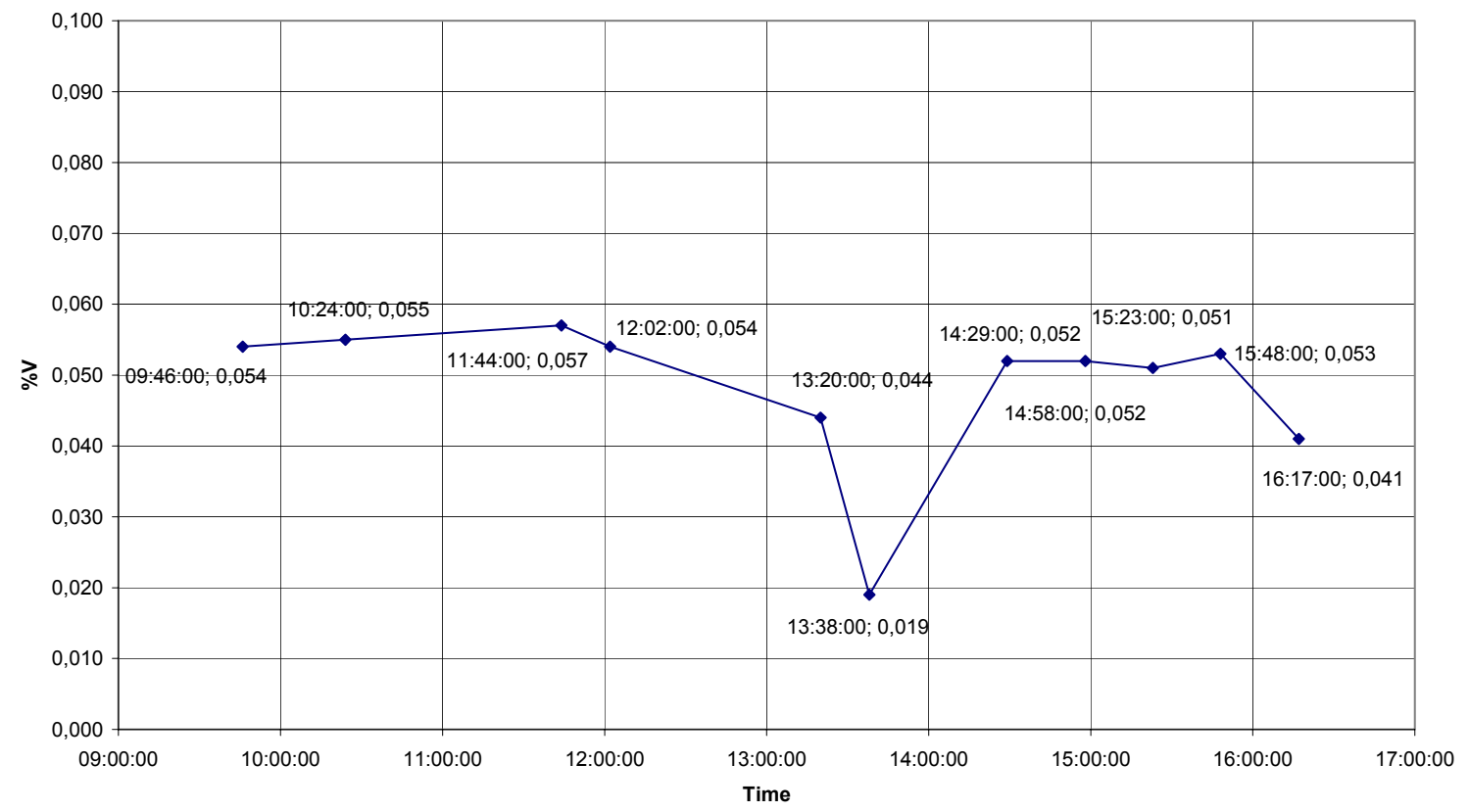


-AI p34 -

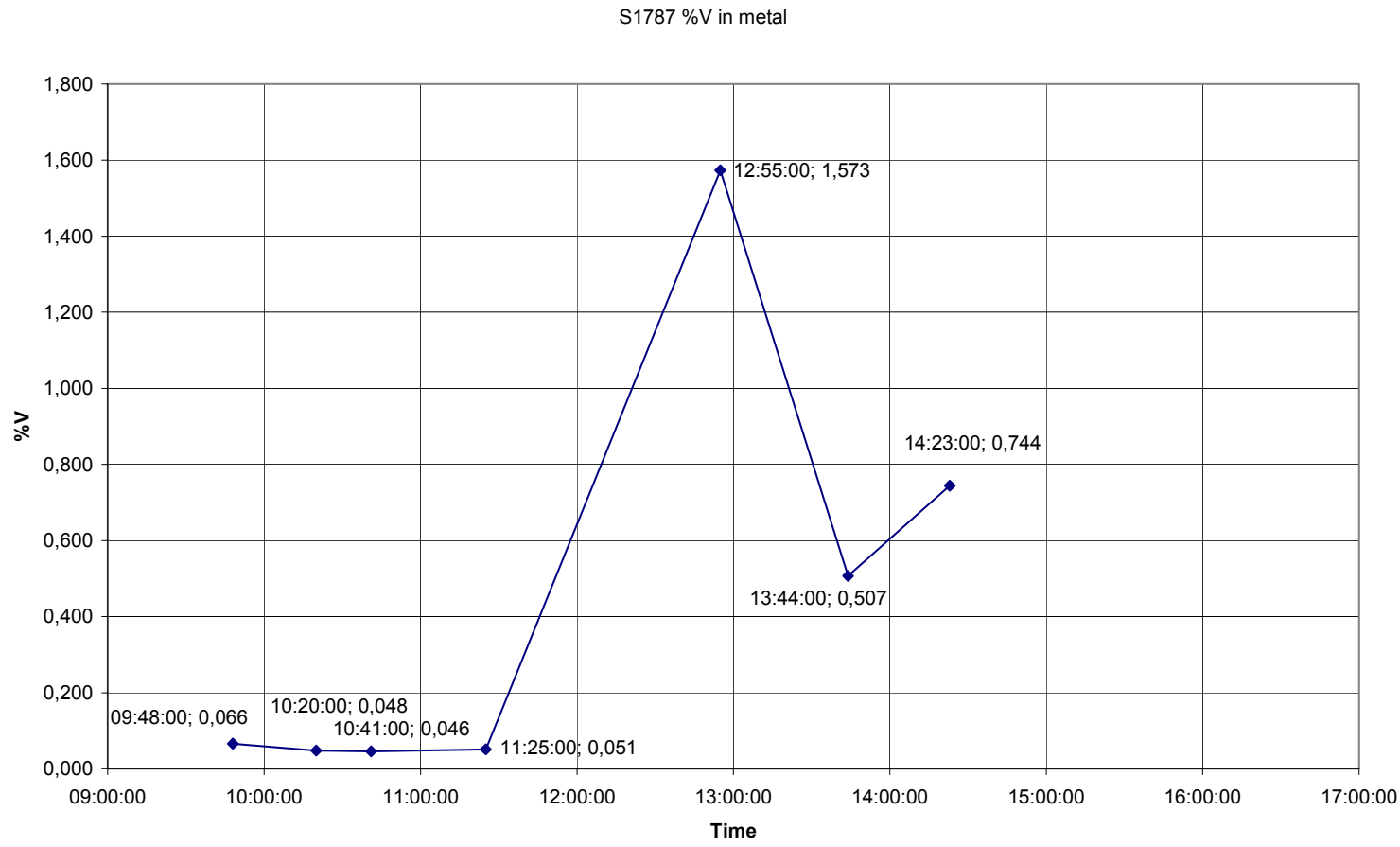

Figure 8 - V analysis in liquid metal HyMelt 2 to 6

\subsection{Slag analysis}

Slag samples are only possible to collect from tilted converter. The method can be used in coming campaigns. 
-AI p35 -

\subsubsection{Iron oxides}

S1783\%Fetot in slag

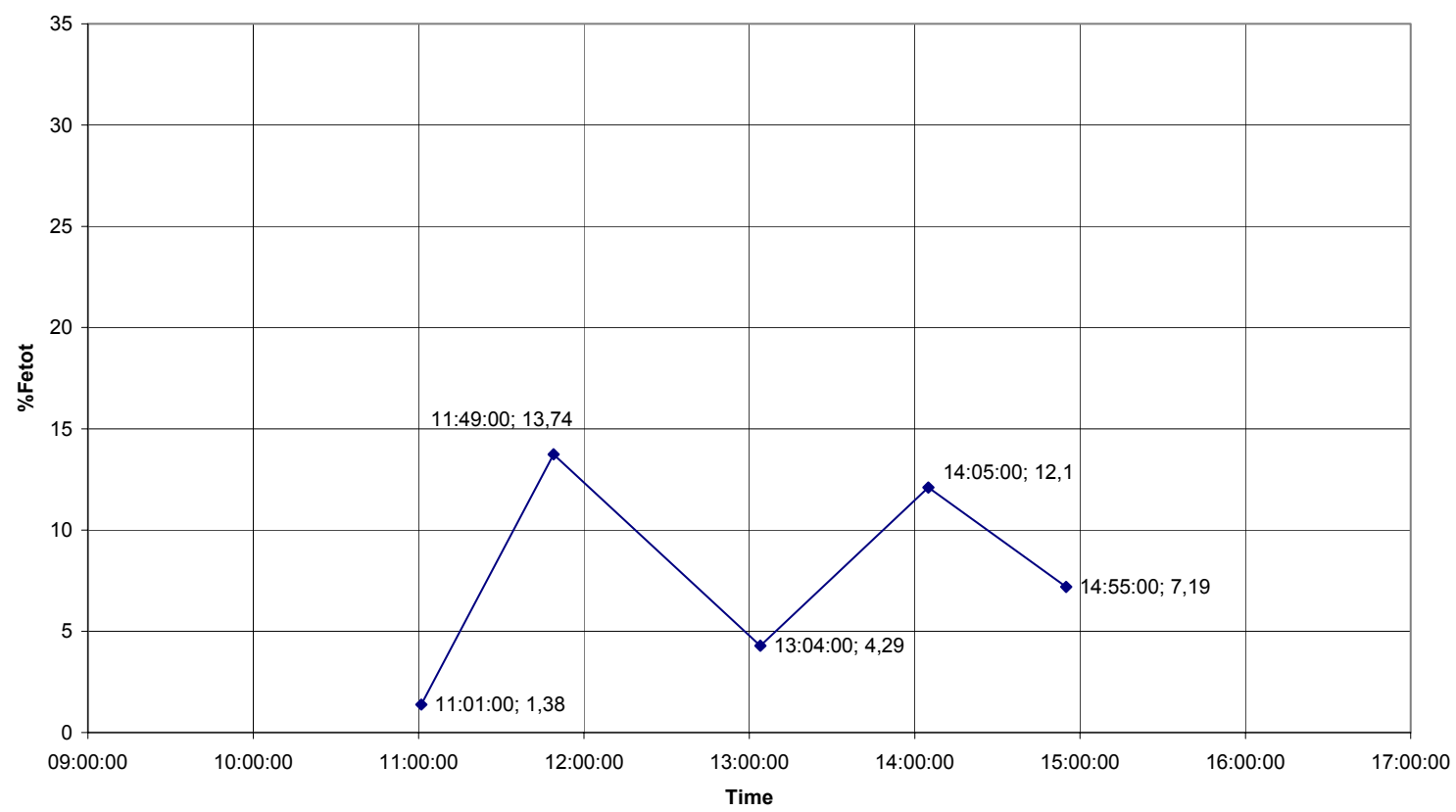

S1784 \% Fetot in slag

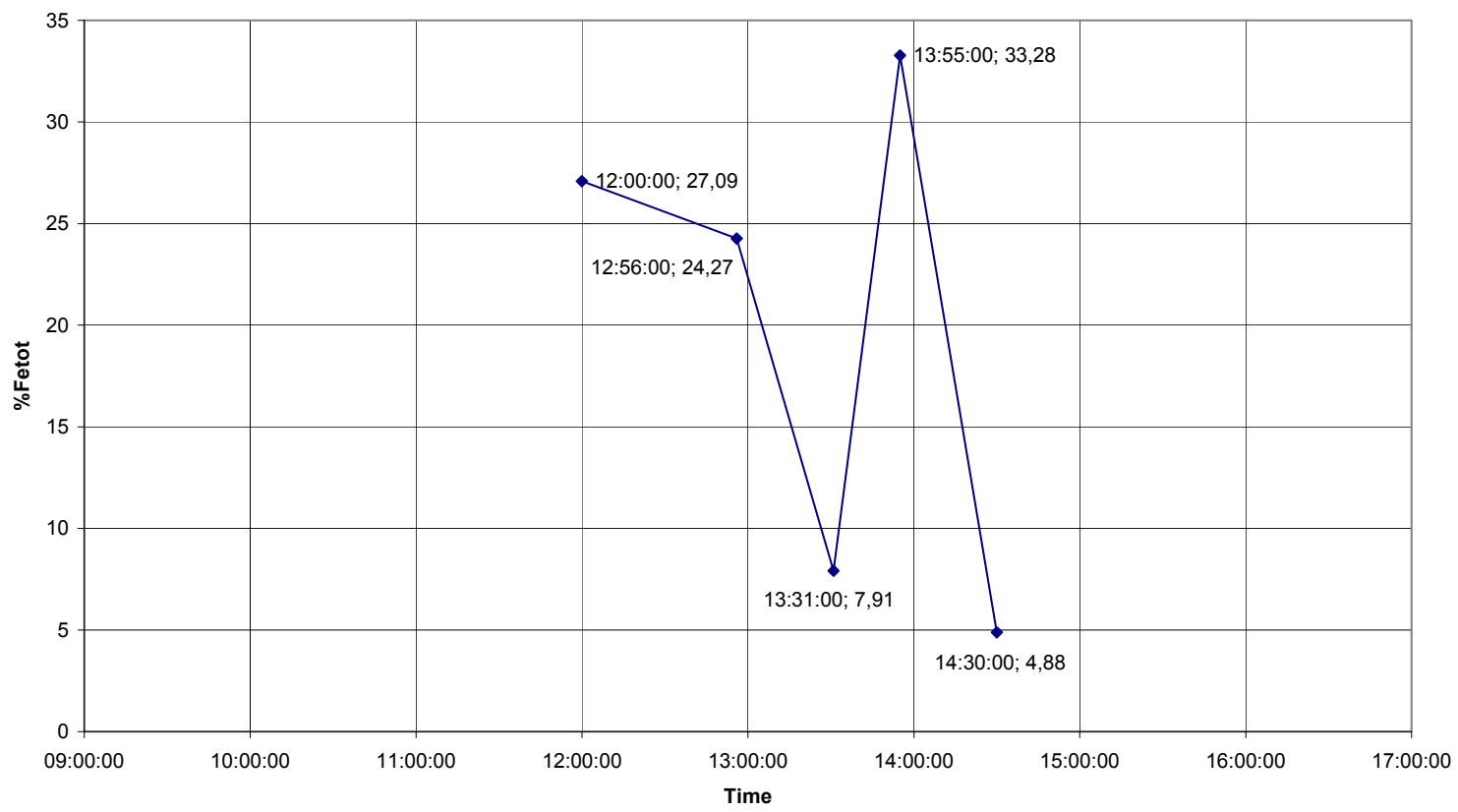


-AI p36 -

S1785 \%Fetot in slag

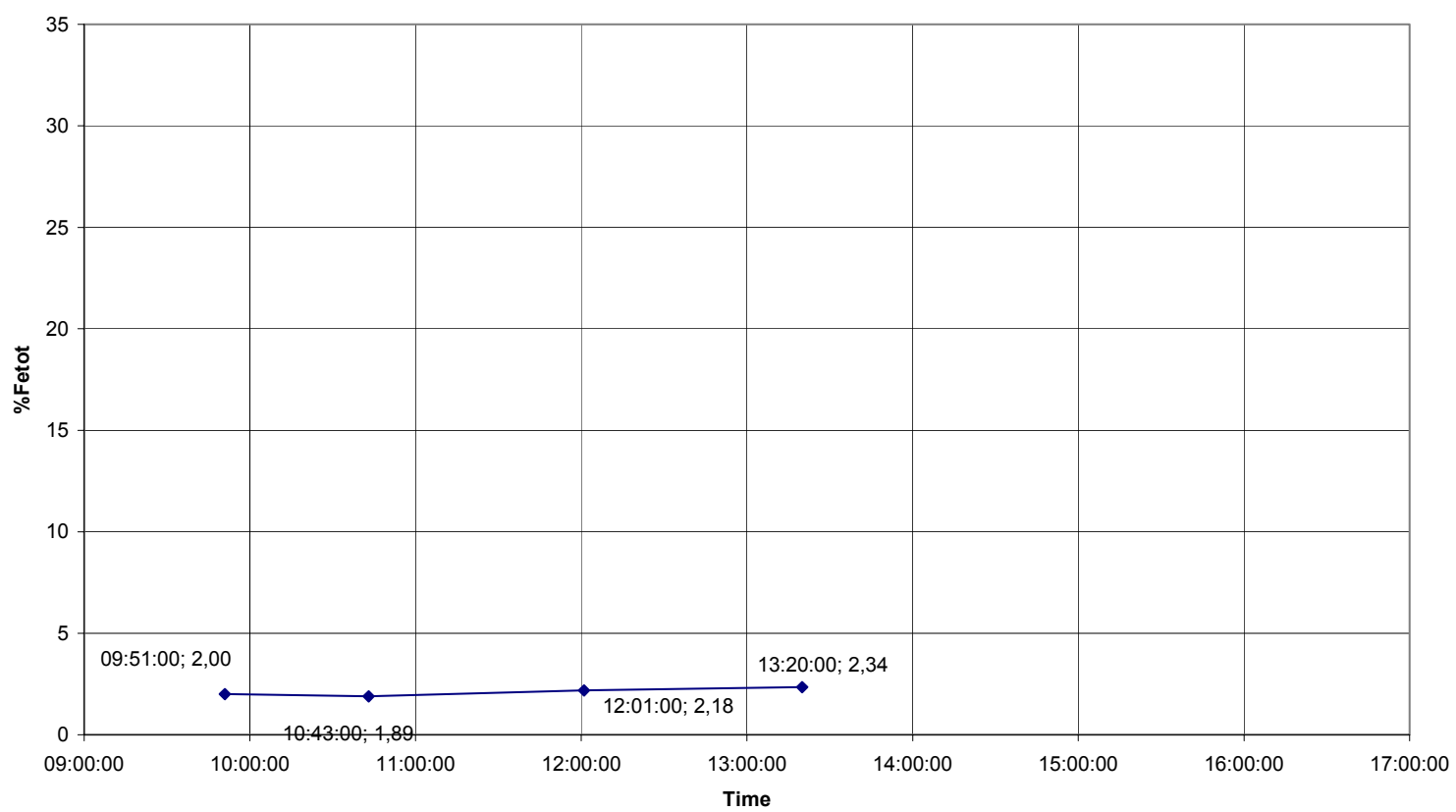

S1786 \%Fetot in slag

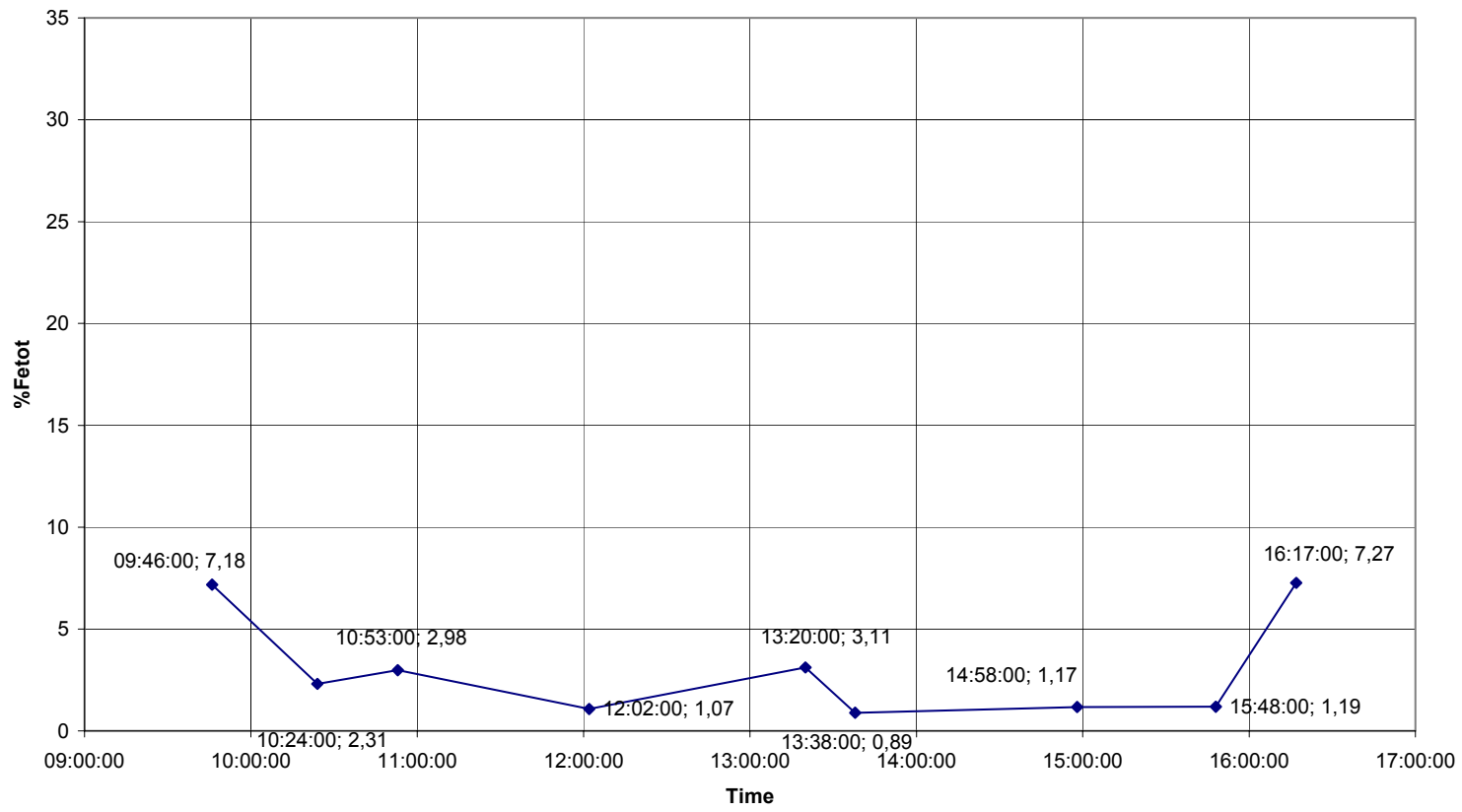


-AI p37 -

S1787 \%Fetot in slag

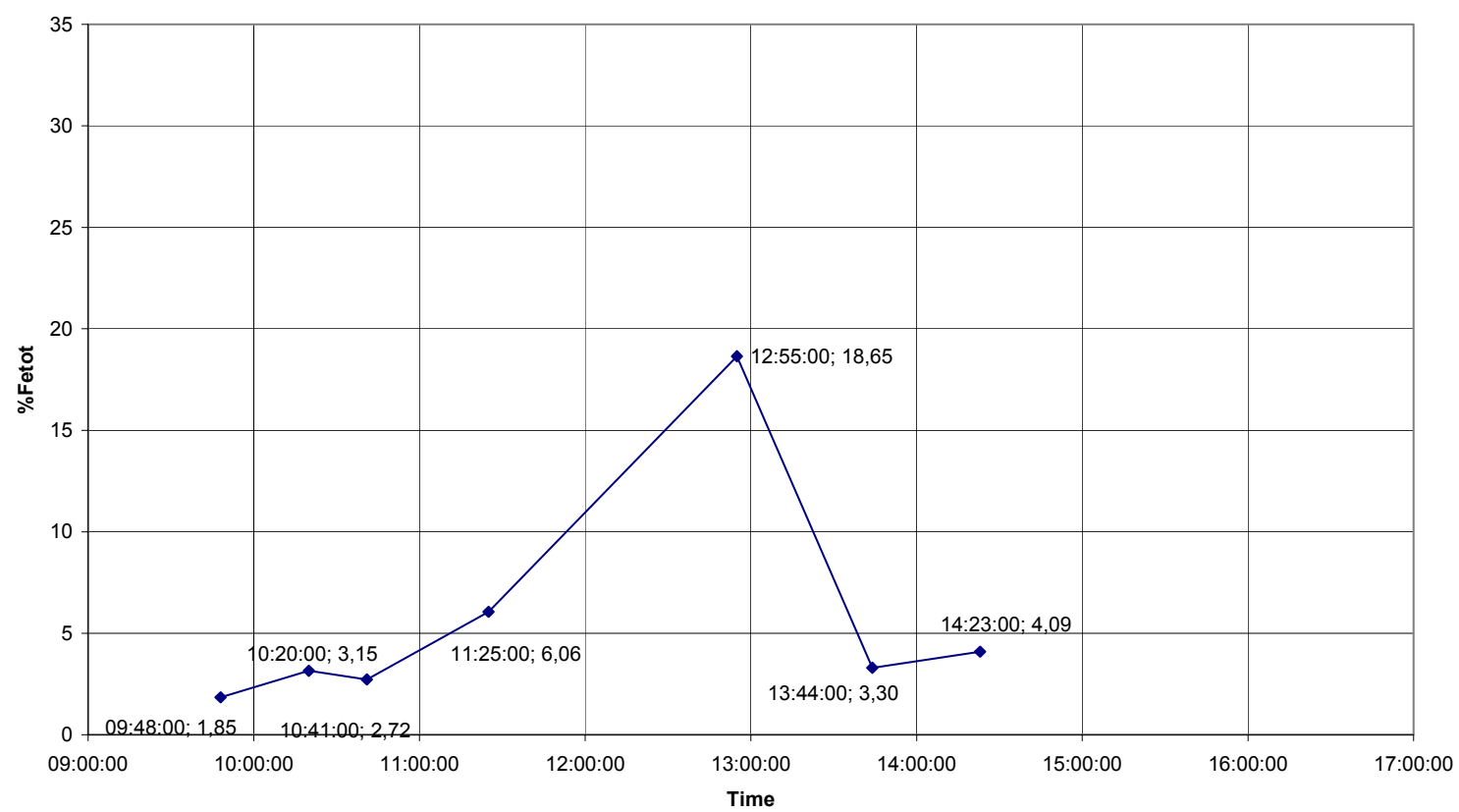

Figure $9-\mathrm{Fe}_{\text {tot }}$ in slag HyMelt 2 to 6

\subsubsection{Sulphur}

S1783 \%S in slag

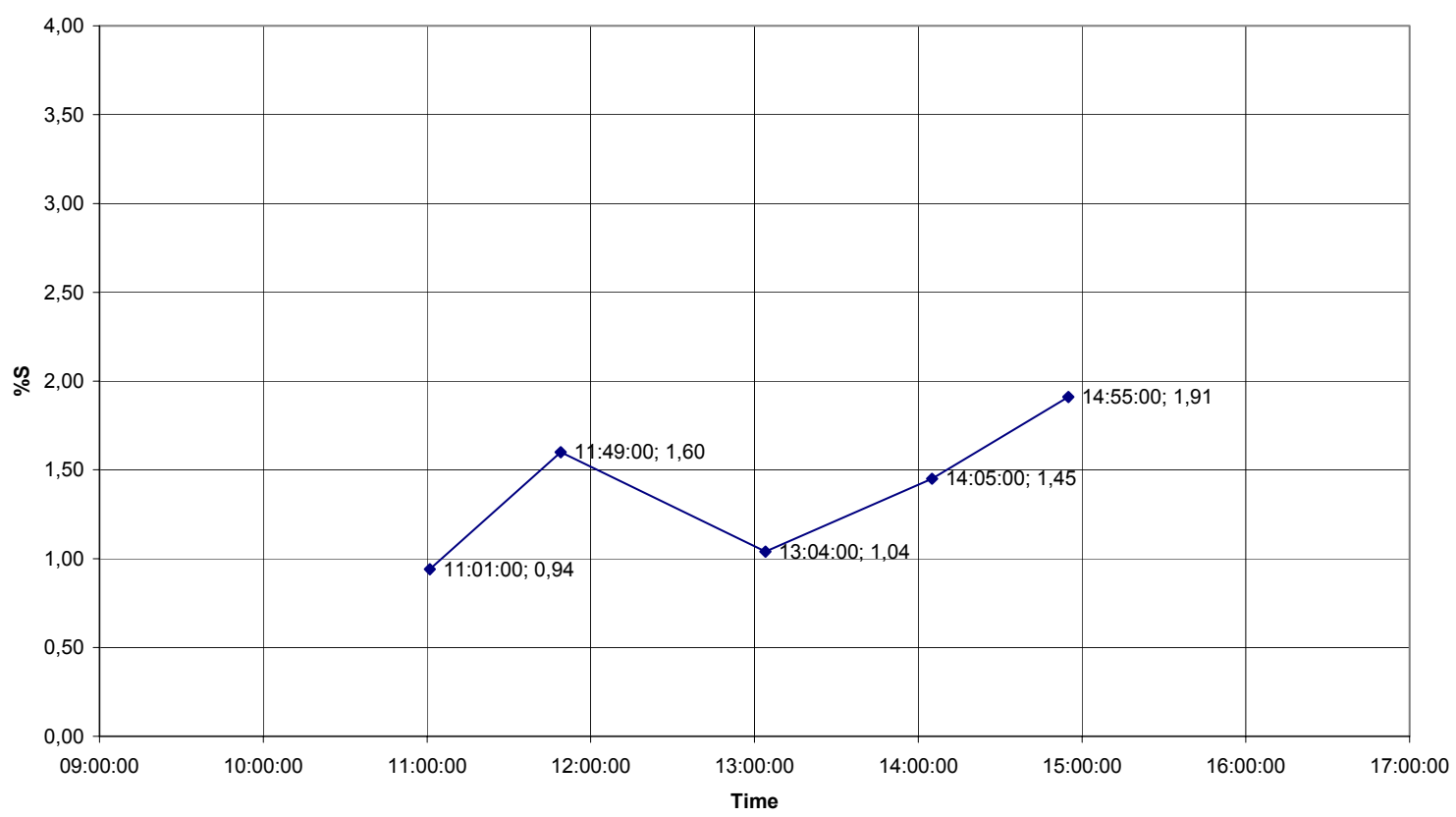


-AI p38 -

S1784 \%S in slag

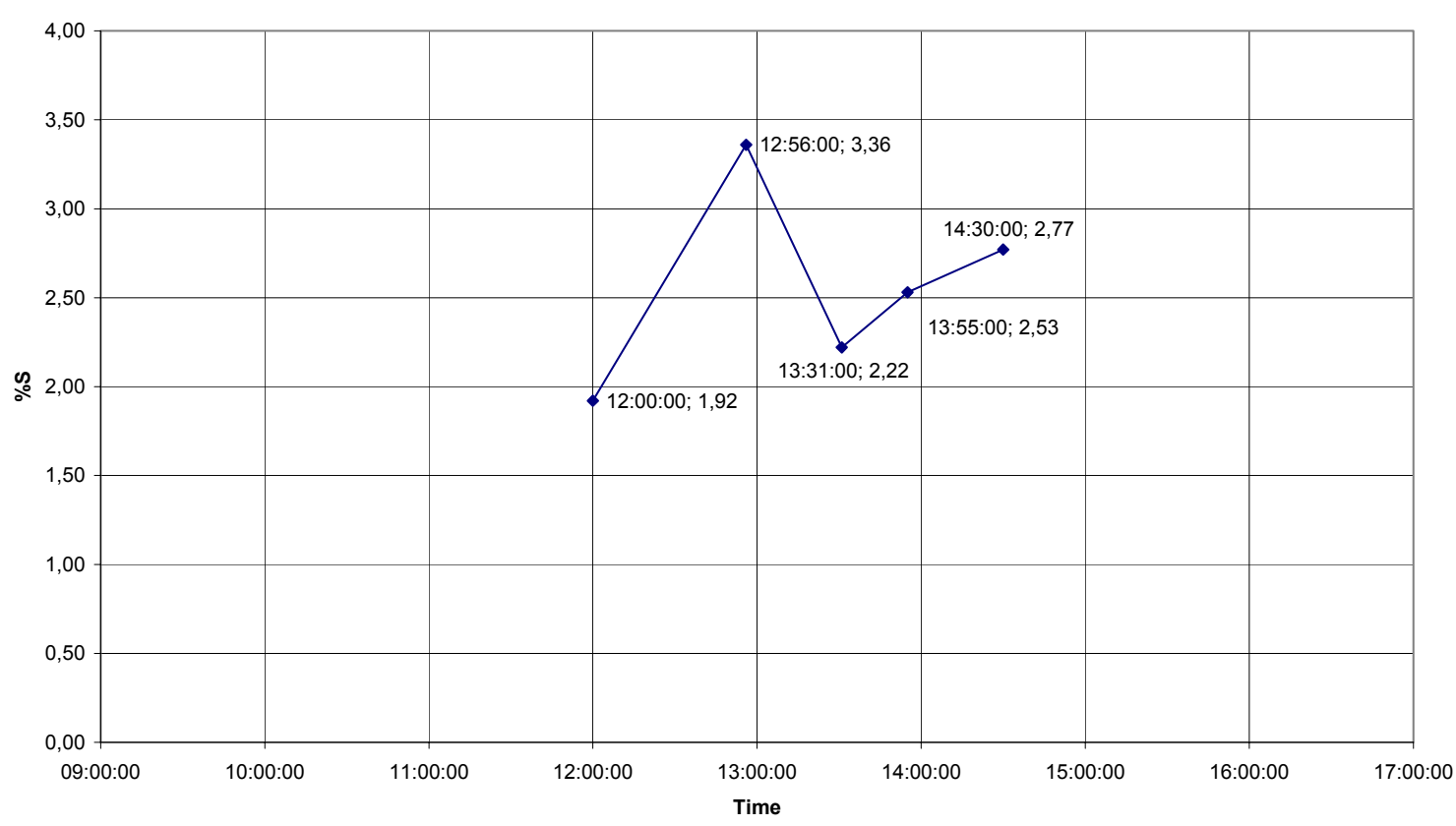

S1785 \%S in slag

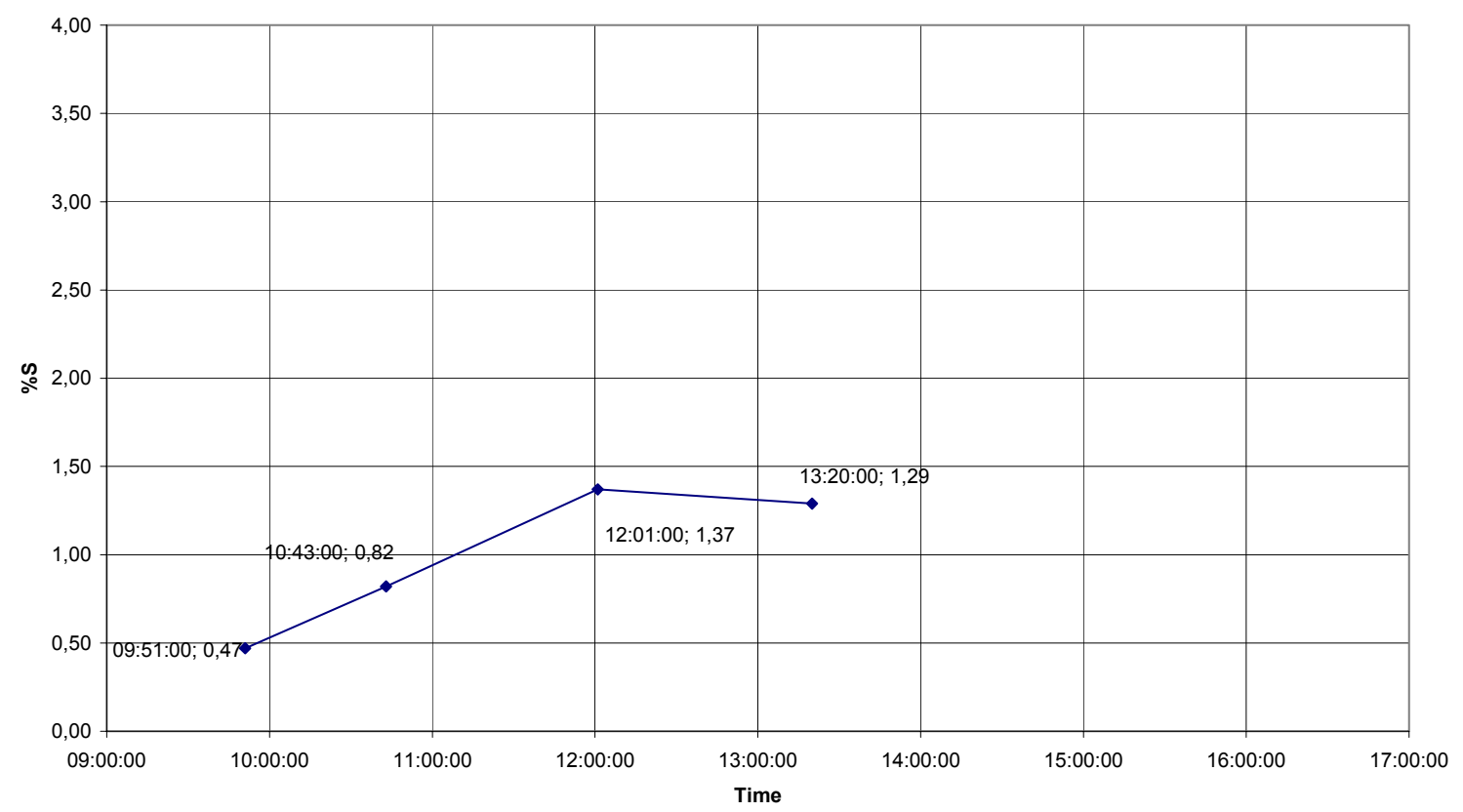


-AI p39-

S1786 \%S in slag

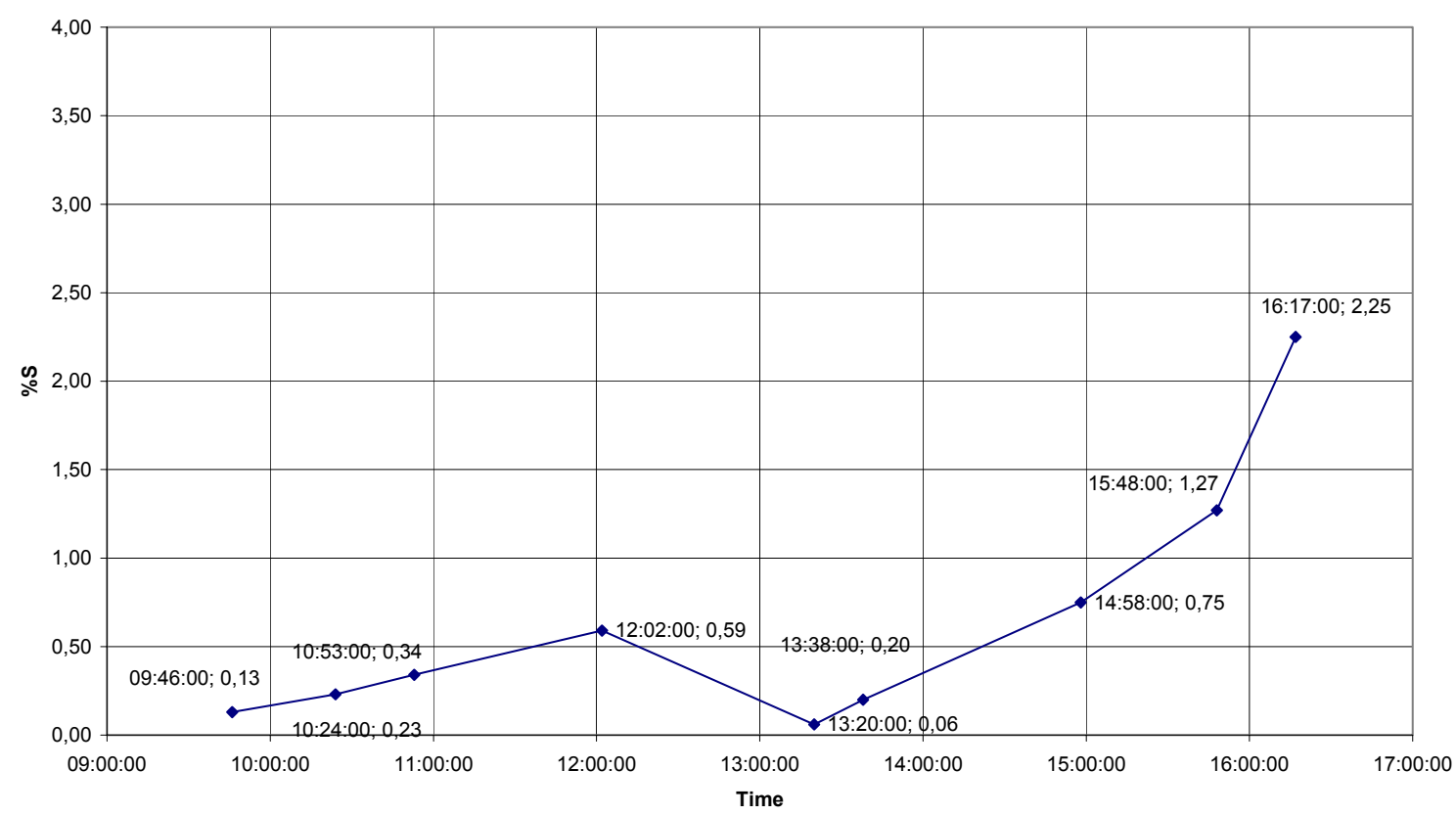

S1787 \%S in slag

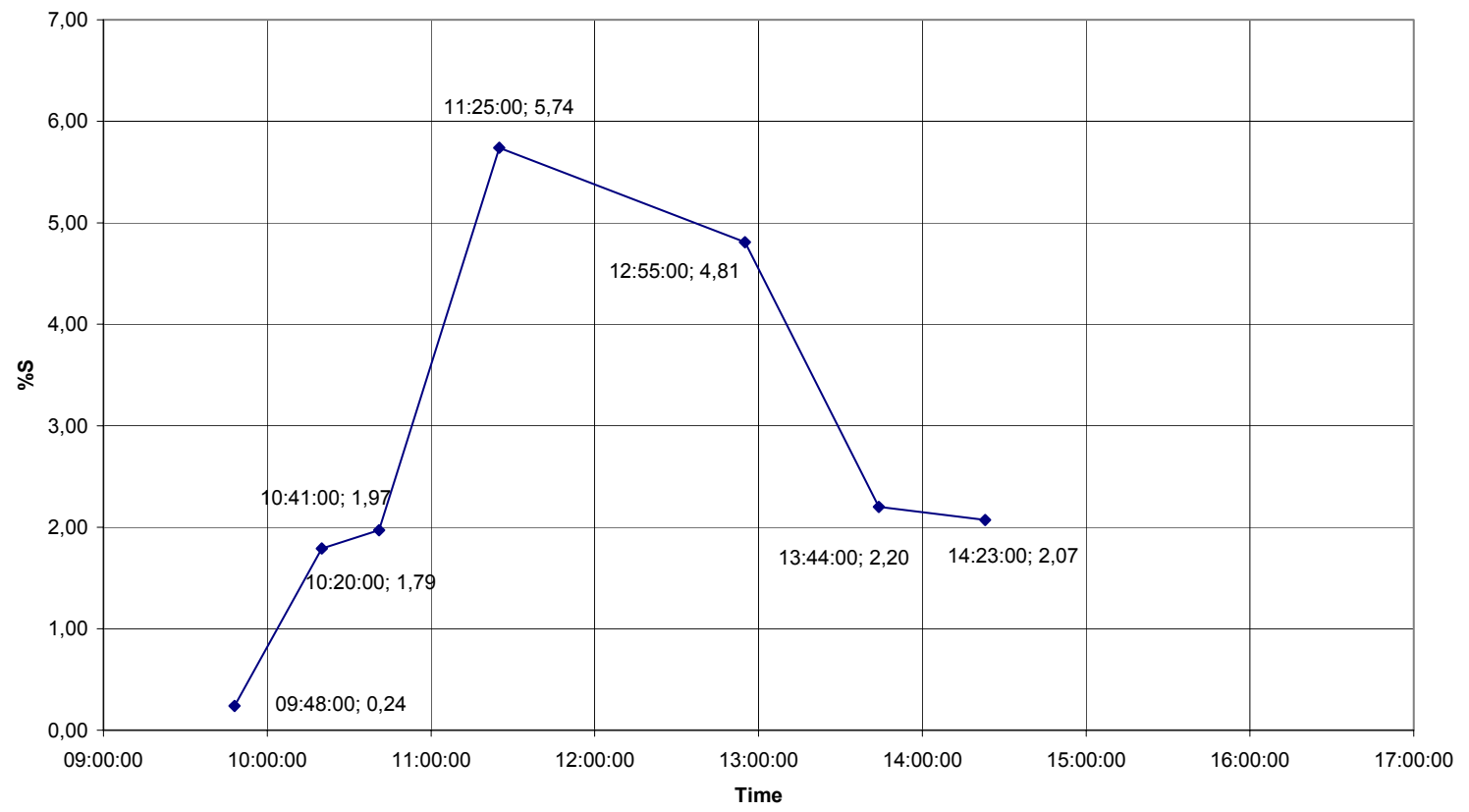

Figure $10-\mathrm{S}$ in slag HyMelt 2 to 6 
-AI p40 -

\subsubsection{Vanadium oxides}
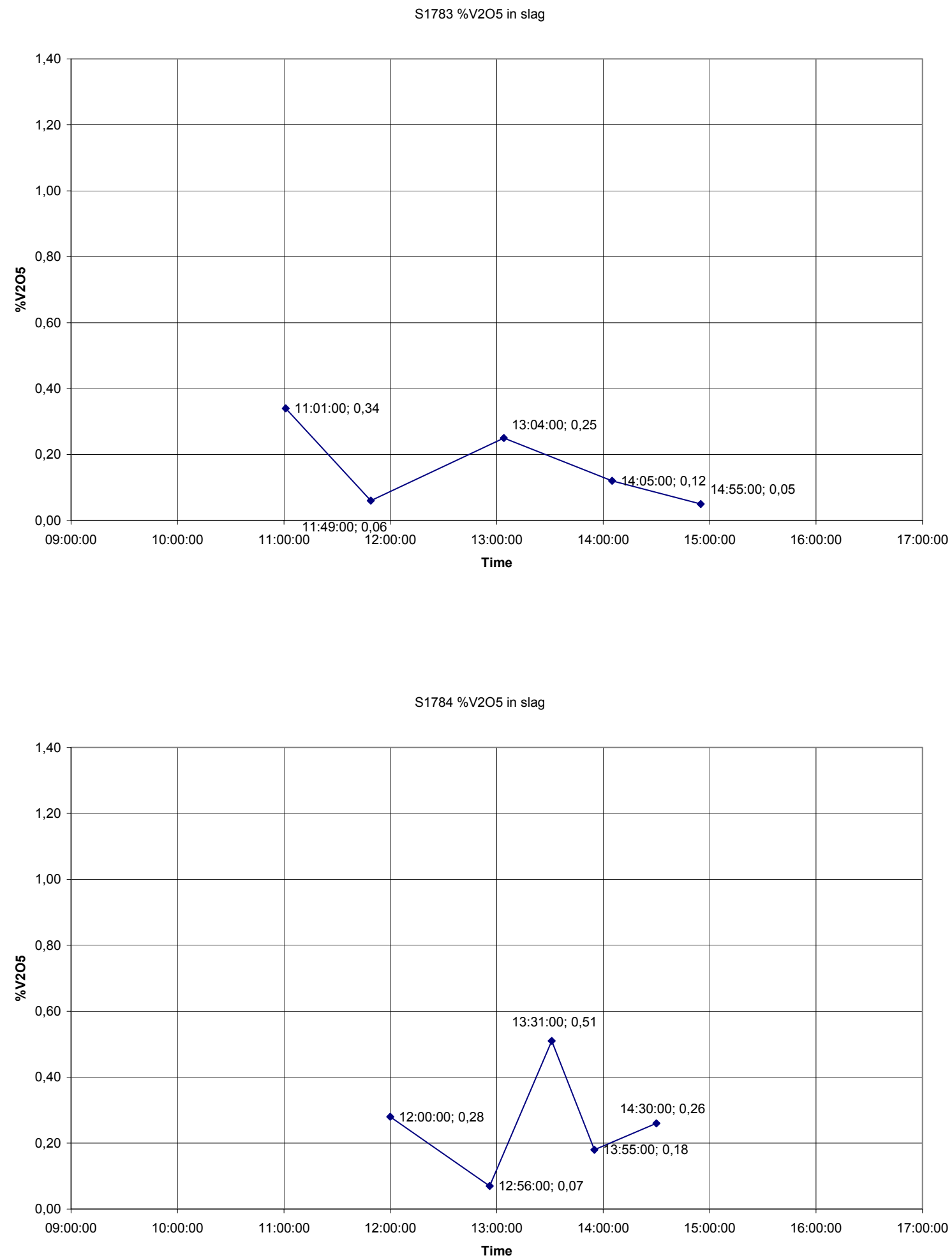
-AI p41 -

S1785 \%V2O5 in slag

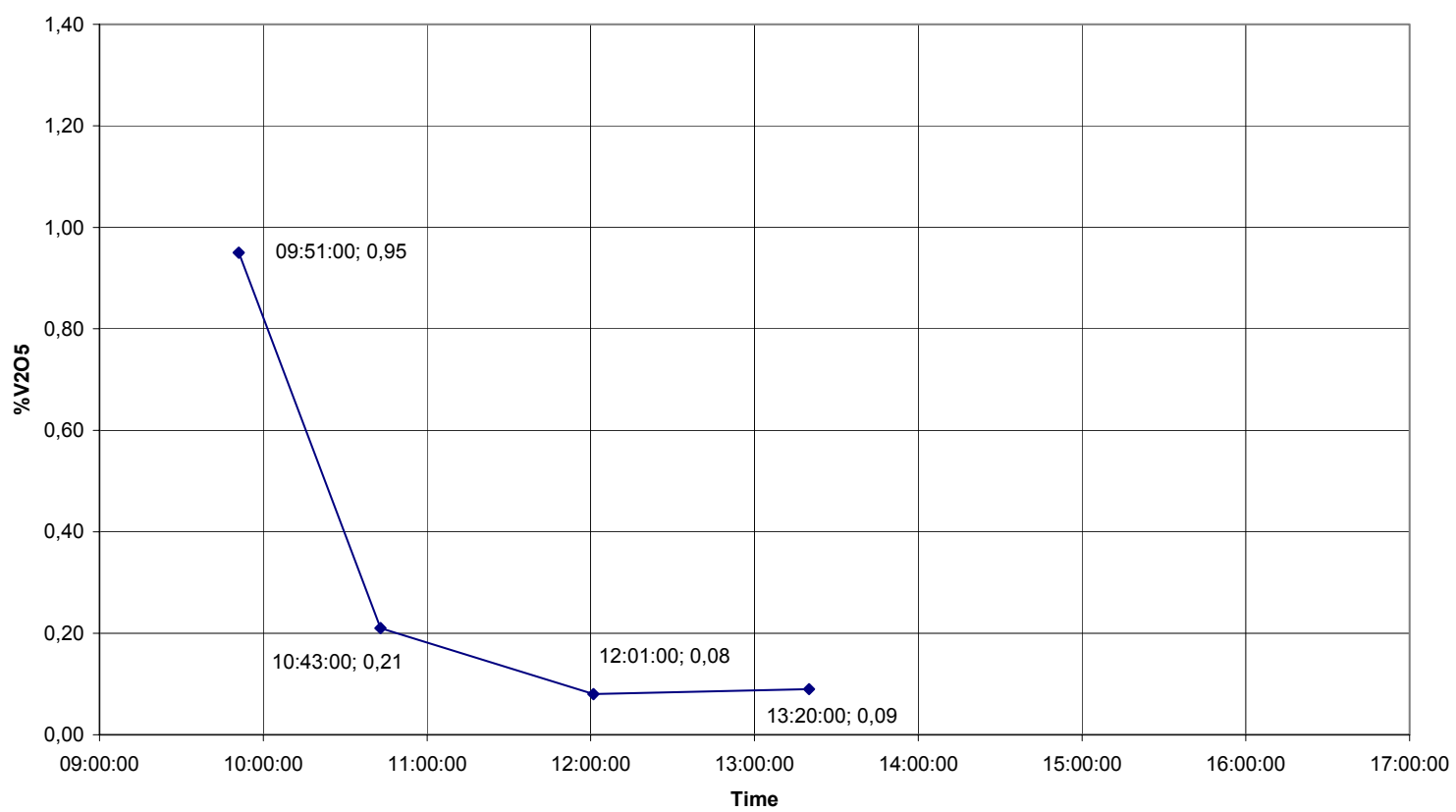

S1786 \%V2O5 in slag

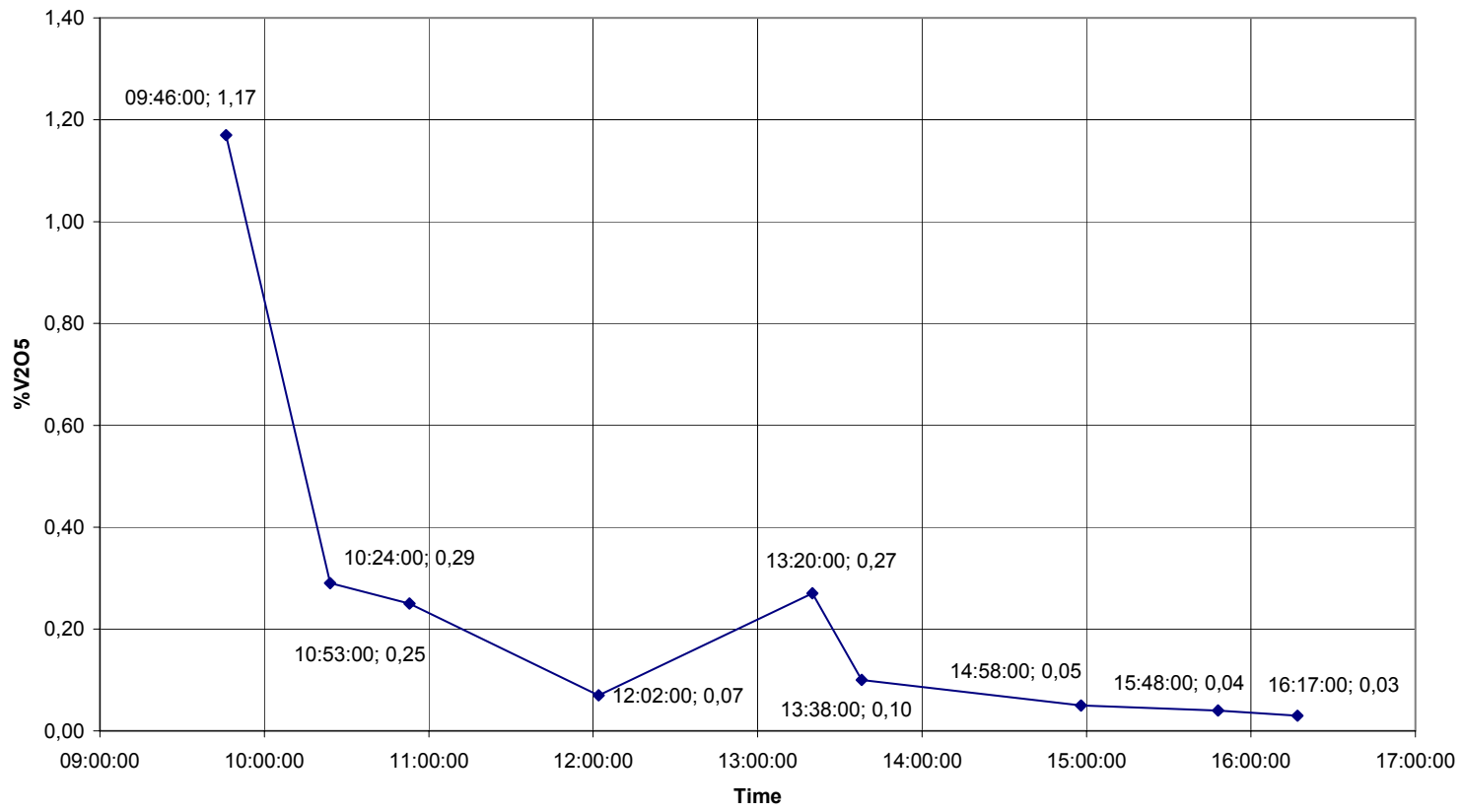


-AI p42 -

S1787 \%V2O5 in slag

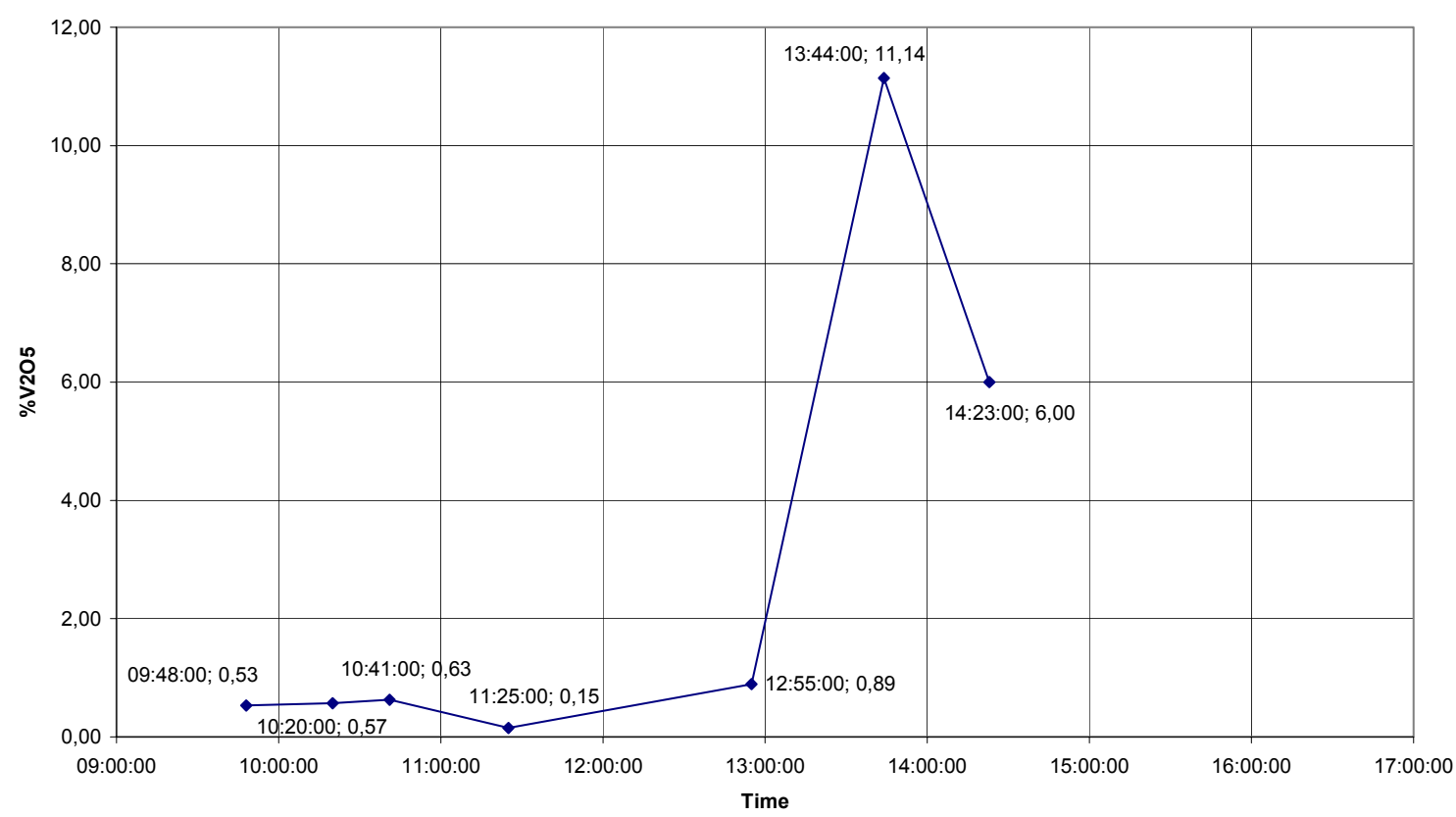

Figure 11 - V-oxides in slag HyMelt 2 to 6

\subsubsection{Bas $\mathrm{CaO} / \mathrm{SiO}_{2}$}

$\mathrm{S} 1783 \mathrm{CaO} / \mathrm{SiO} 2$ in slag

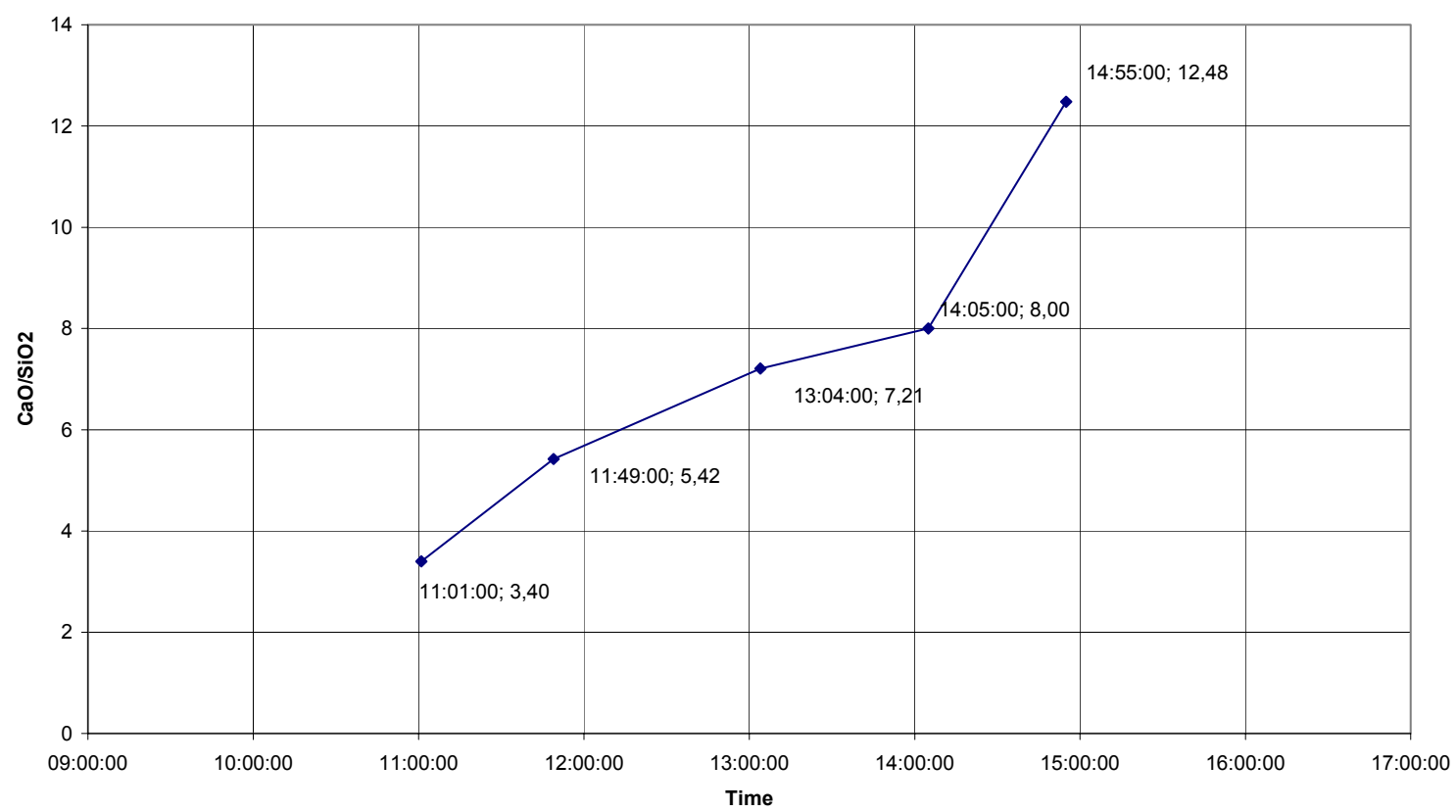


-AI p43 -

$\mathrm{S} 1784 \mathrm{CaO} / \mathrm{SiO} 2$ in slag

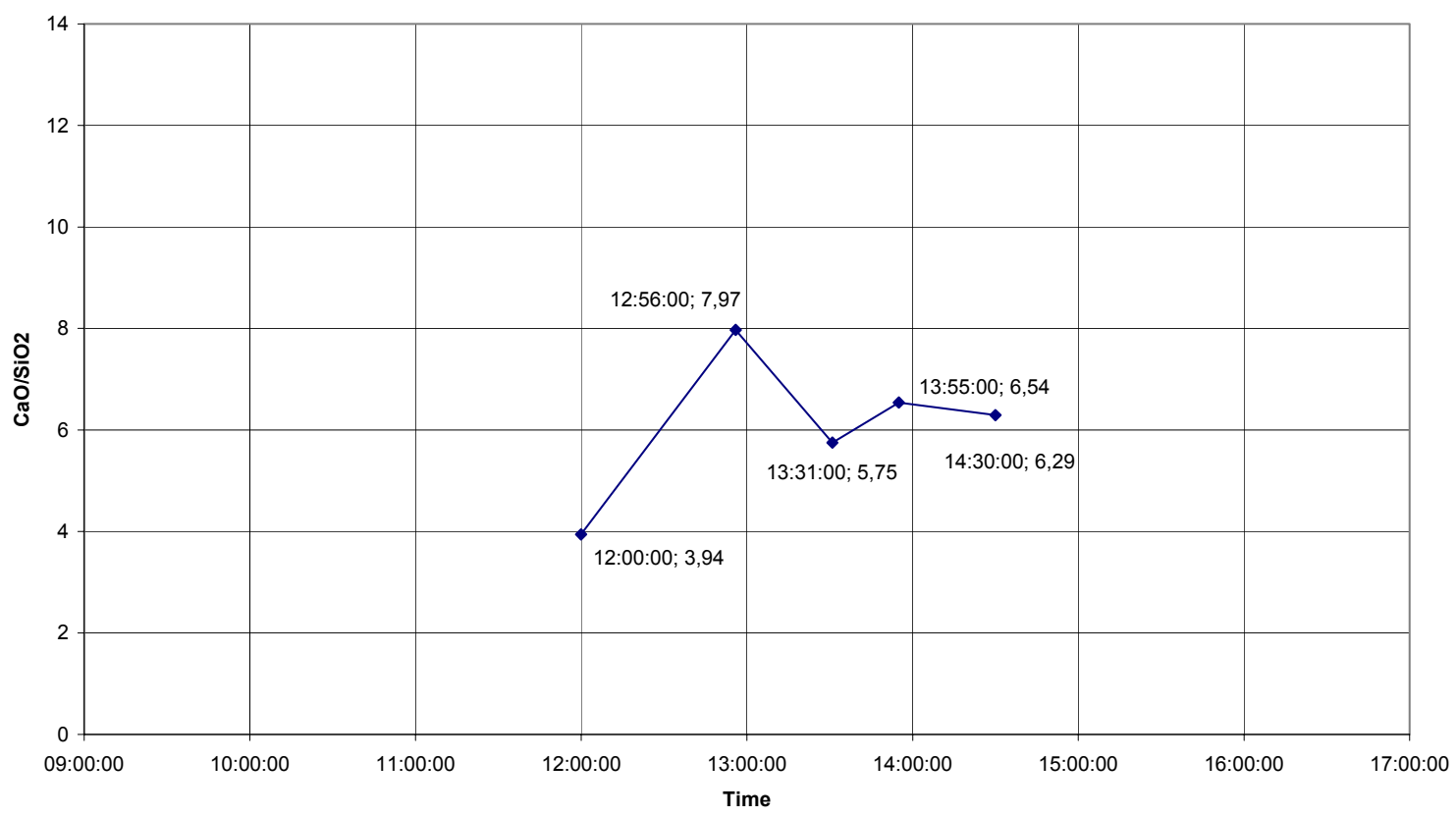

$\mathrm{S} 1785 \mathrm{CaO} / \mathrm{SiO} 2$ in slag

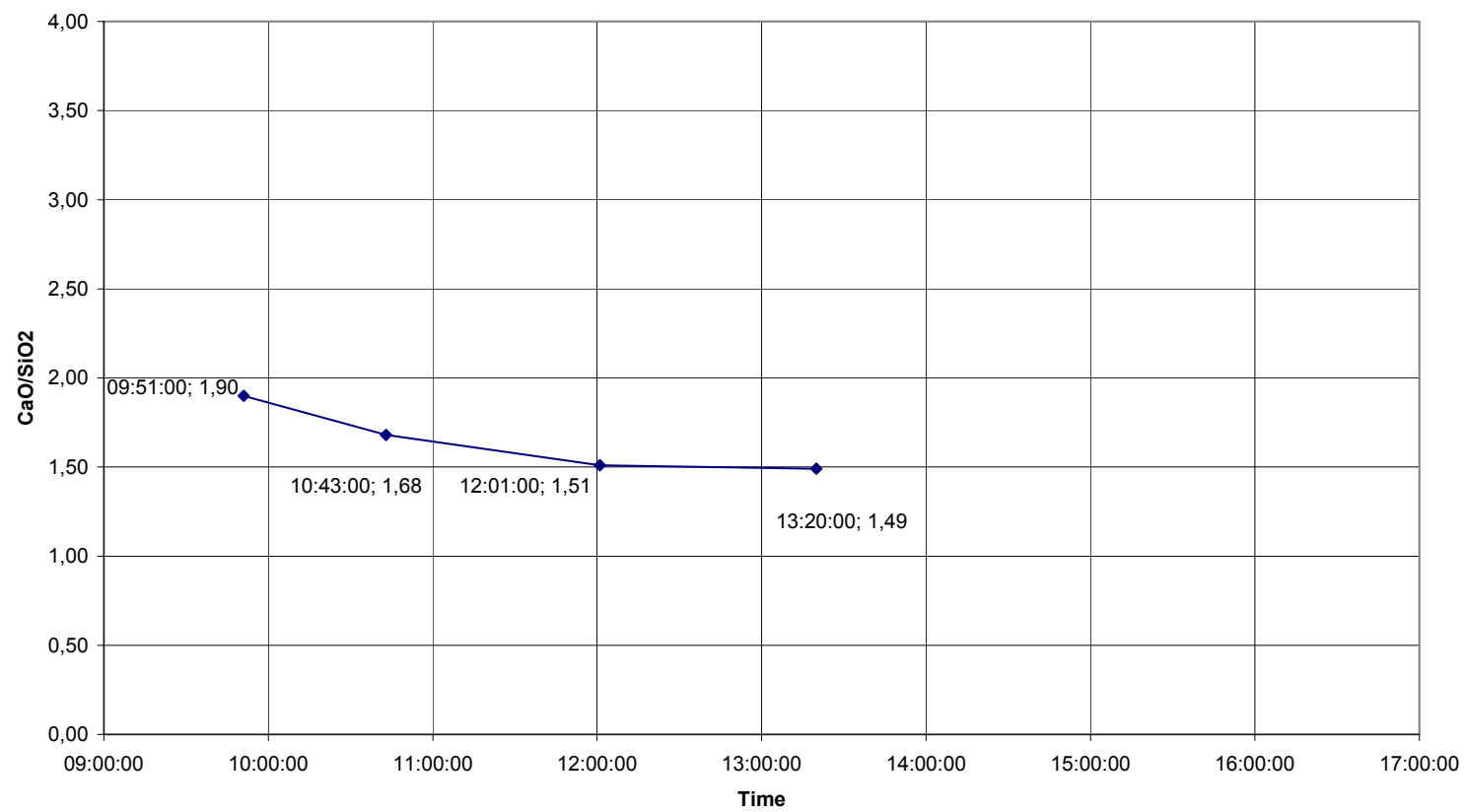


-AI p44 -

$\mathrm{S} 1786 \mathrm{CaO} / \mathrm{SiO} 2$ in slag

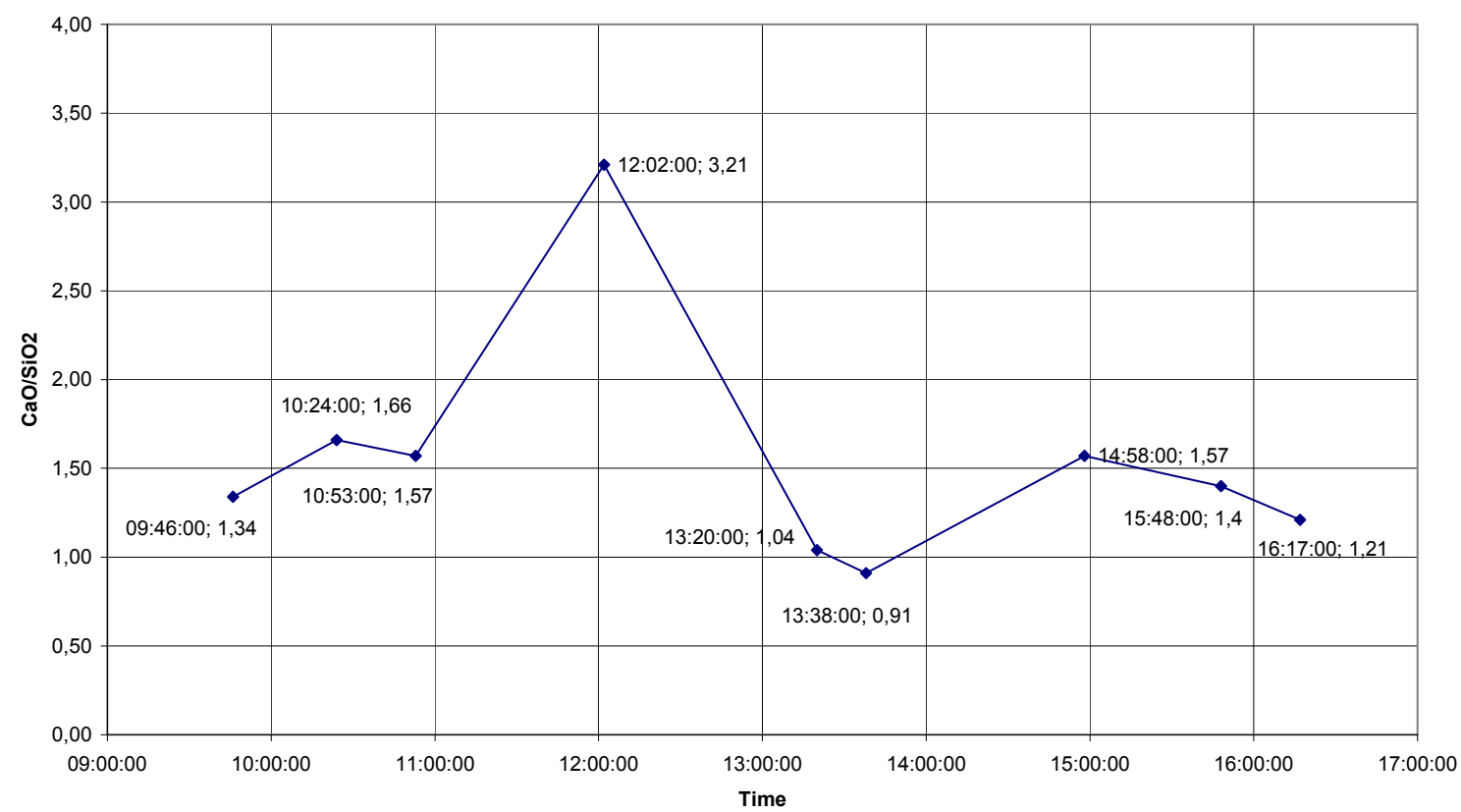

$\mathrm{S} 1787 \mathrm{CaO} / \mathrm{SiO} 2$ in slag

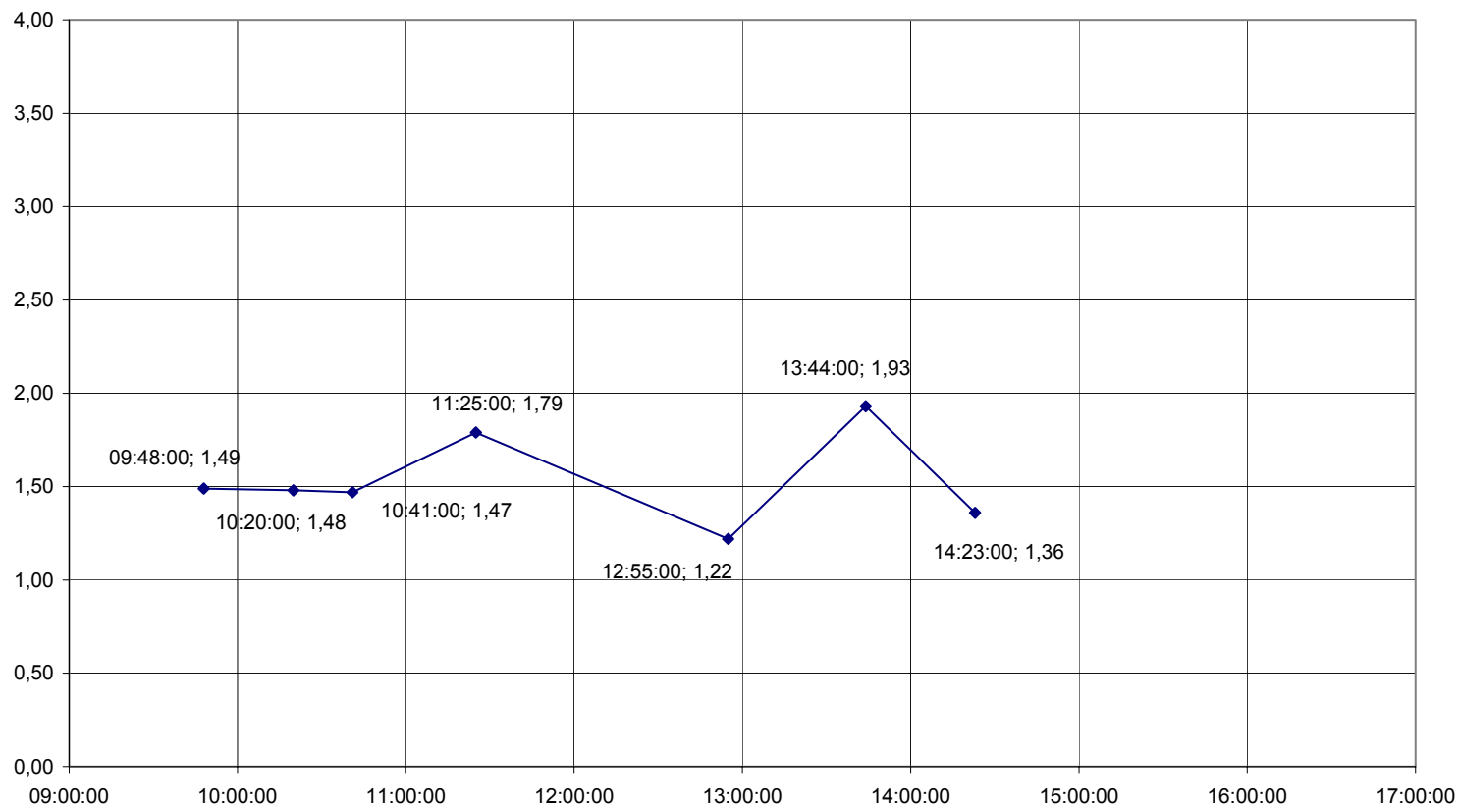

Figure $12-\mathrm{CaO} / \mathrm{SiO}_{2}$ ratio in slag HyMelt 2 to 6 


\subsection{Temperatures}

The metal temperatures refer either from sub-lance measurements or manual lance measurements. The system and code for evaluation of the EMK must be improved in the Lab View system, presented values are manually evaluated.

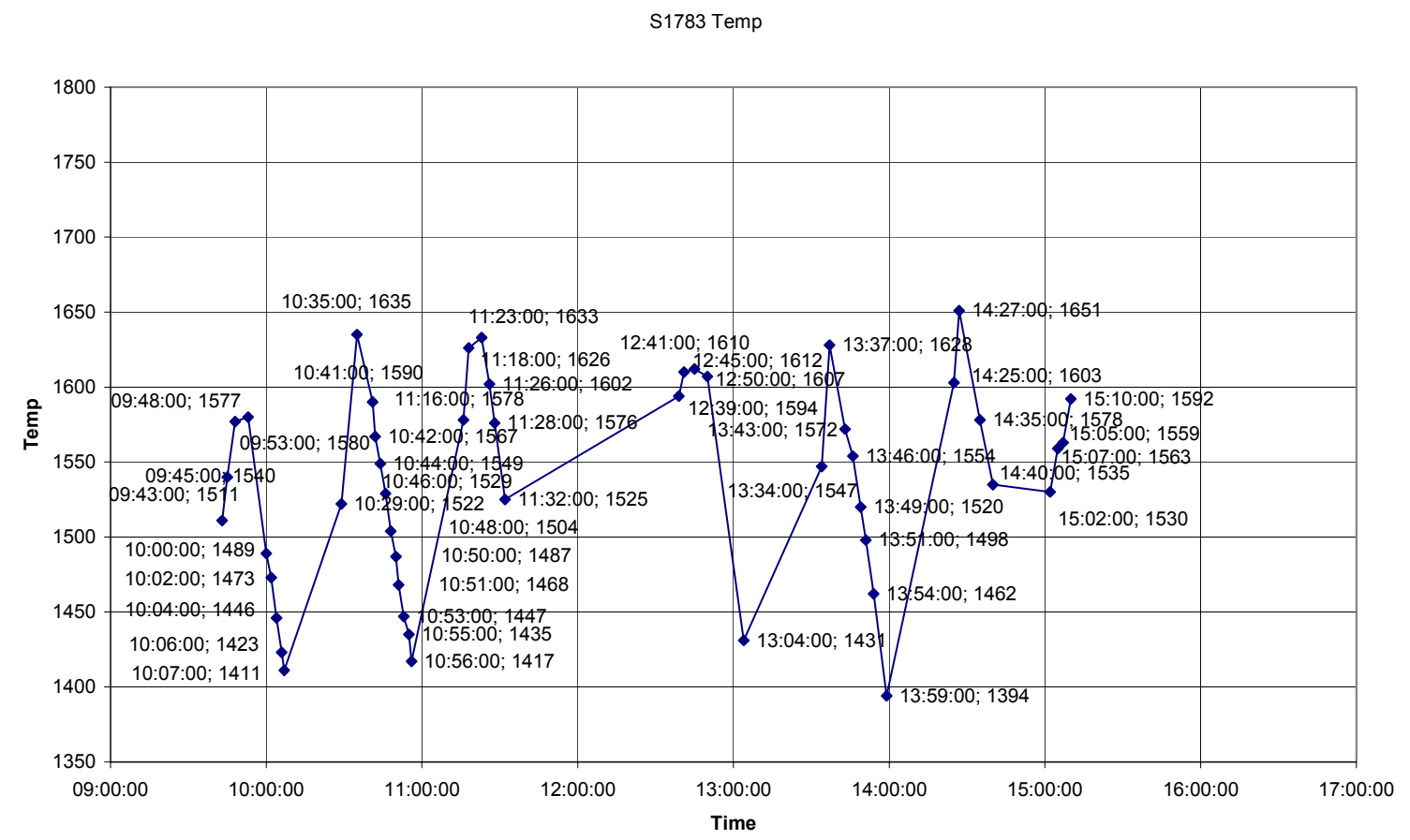




\section{-AI p46 -}

S1784 Temp

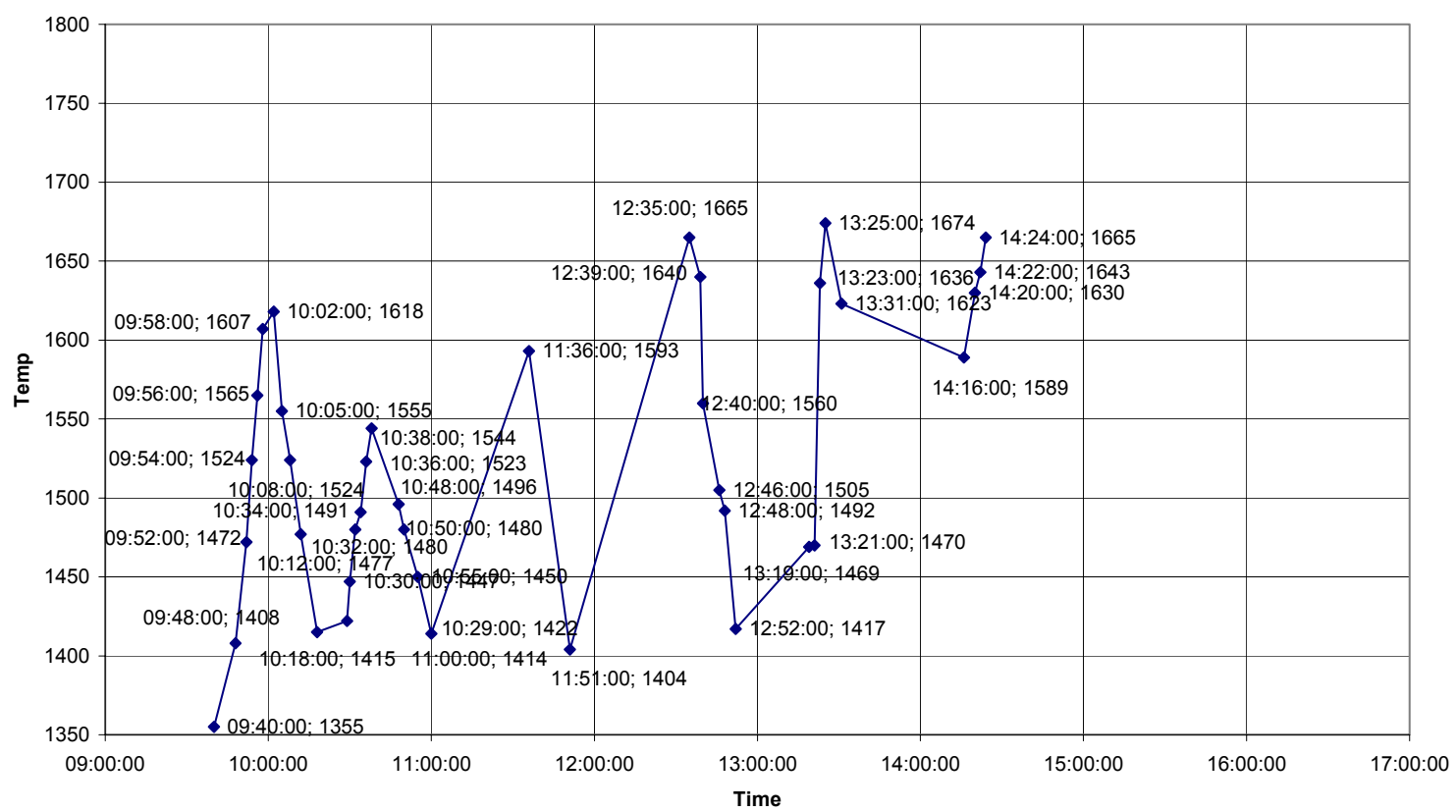

S1785 Temp

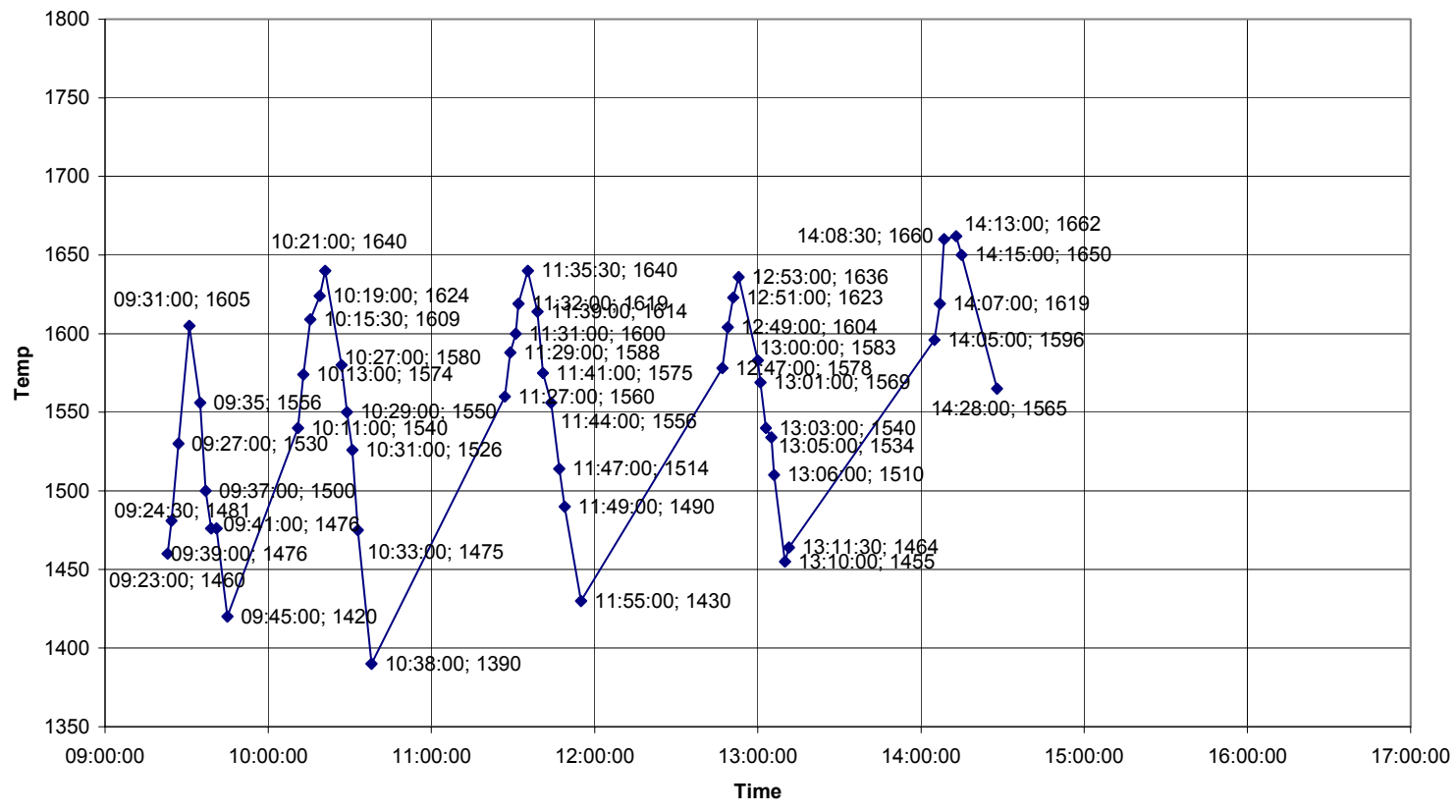




\section{-AI p47 -}

S1786 Temp

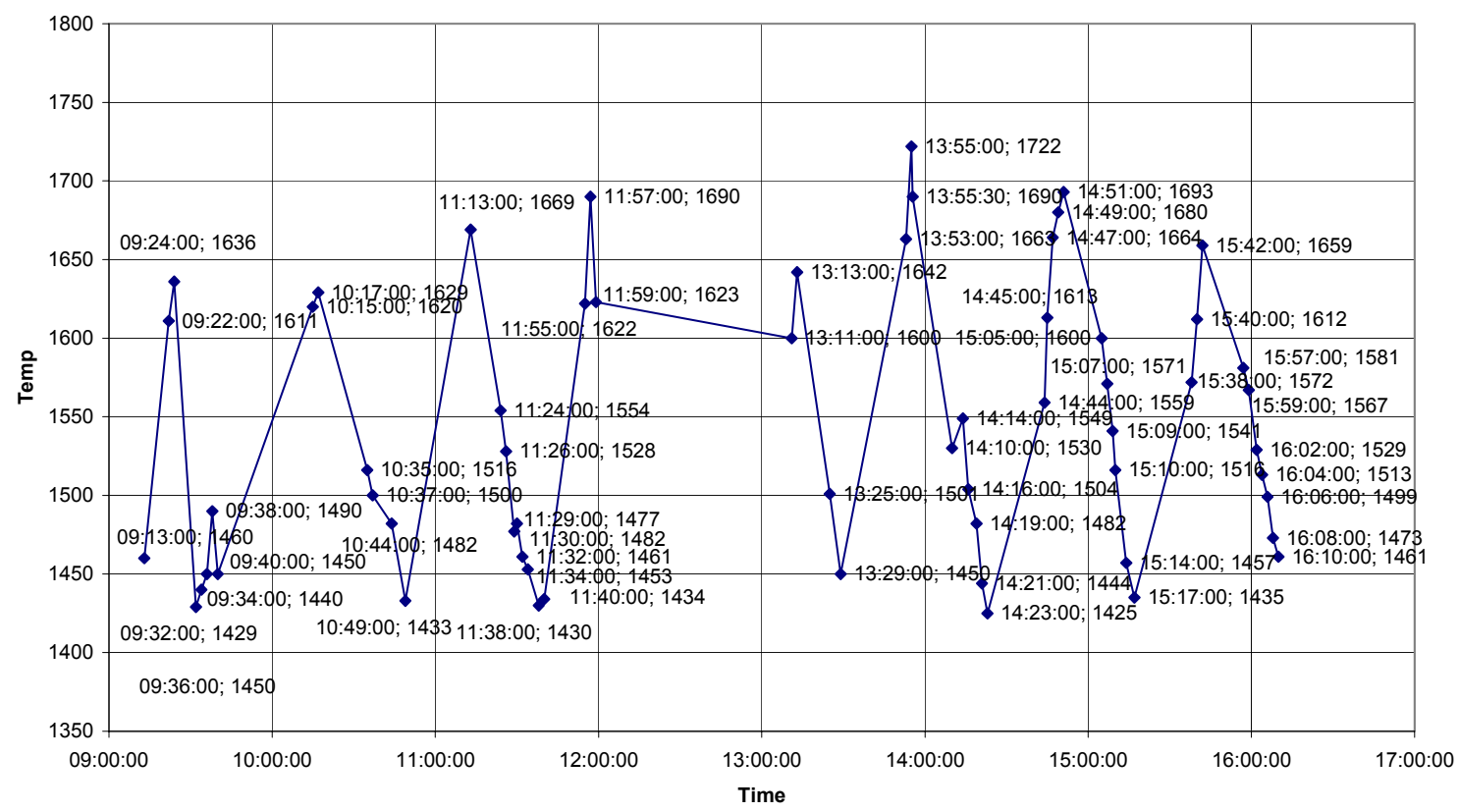

S1787 Temp

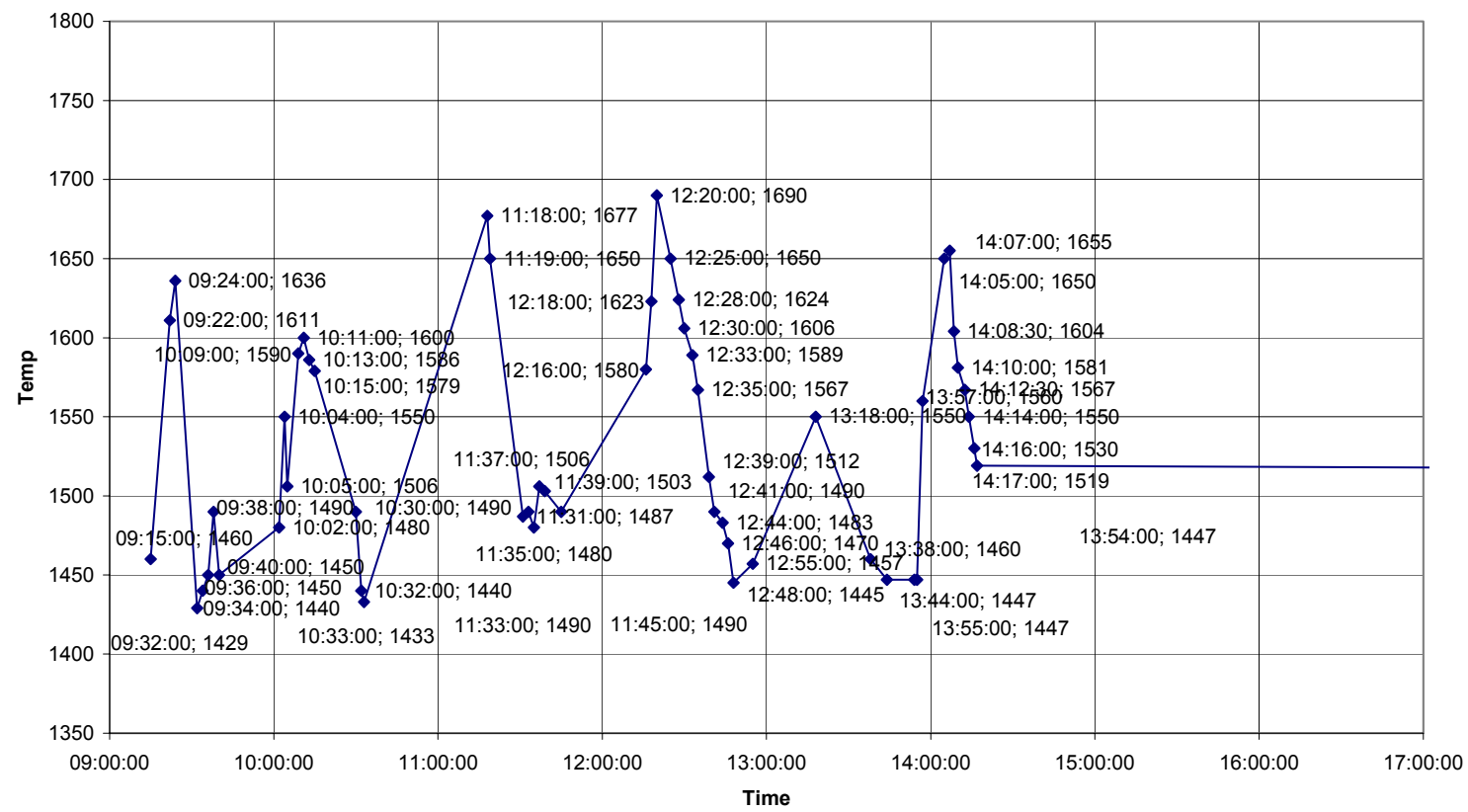

Figure 13 - Temperature in liquid metal HyMelt 2 to 6 


\subsection{Carbon yield to metal}

The carbon yield has been calculated for all injection periods. The calculation is based on the first and last metal analysis in the period and the injected amount of carbon during the time between sampling. Details are shown in Appendix 4.

The best results were archived for pet-coke at moderate feeding rate. A rather strong dependence between yield and feeding rate can be seen. The expected relation between nozzle diameter and yield can not be detected.

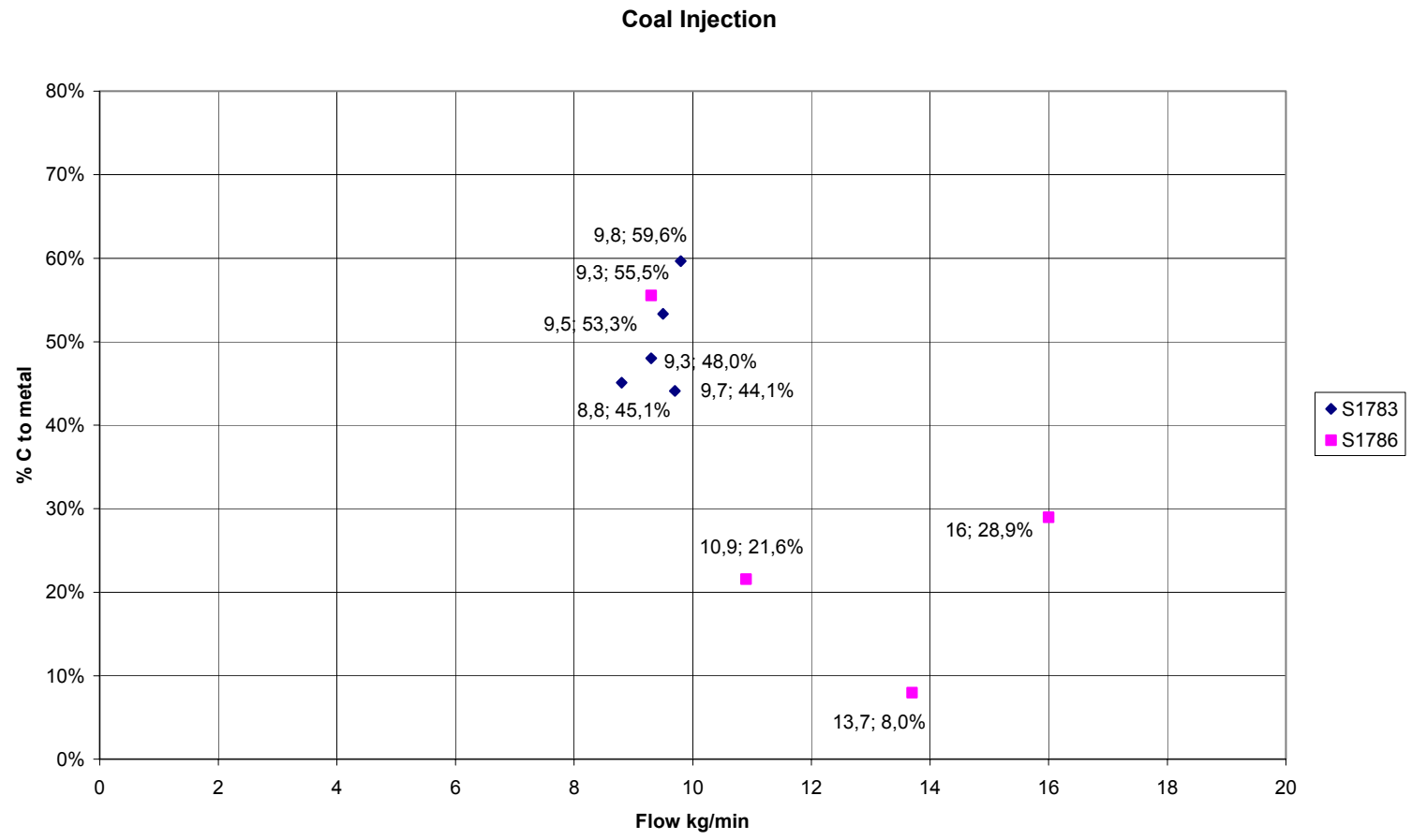

Figure 14 - C yield for coal injection 
-AI p49 -

P-Coke Injection

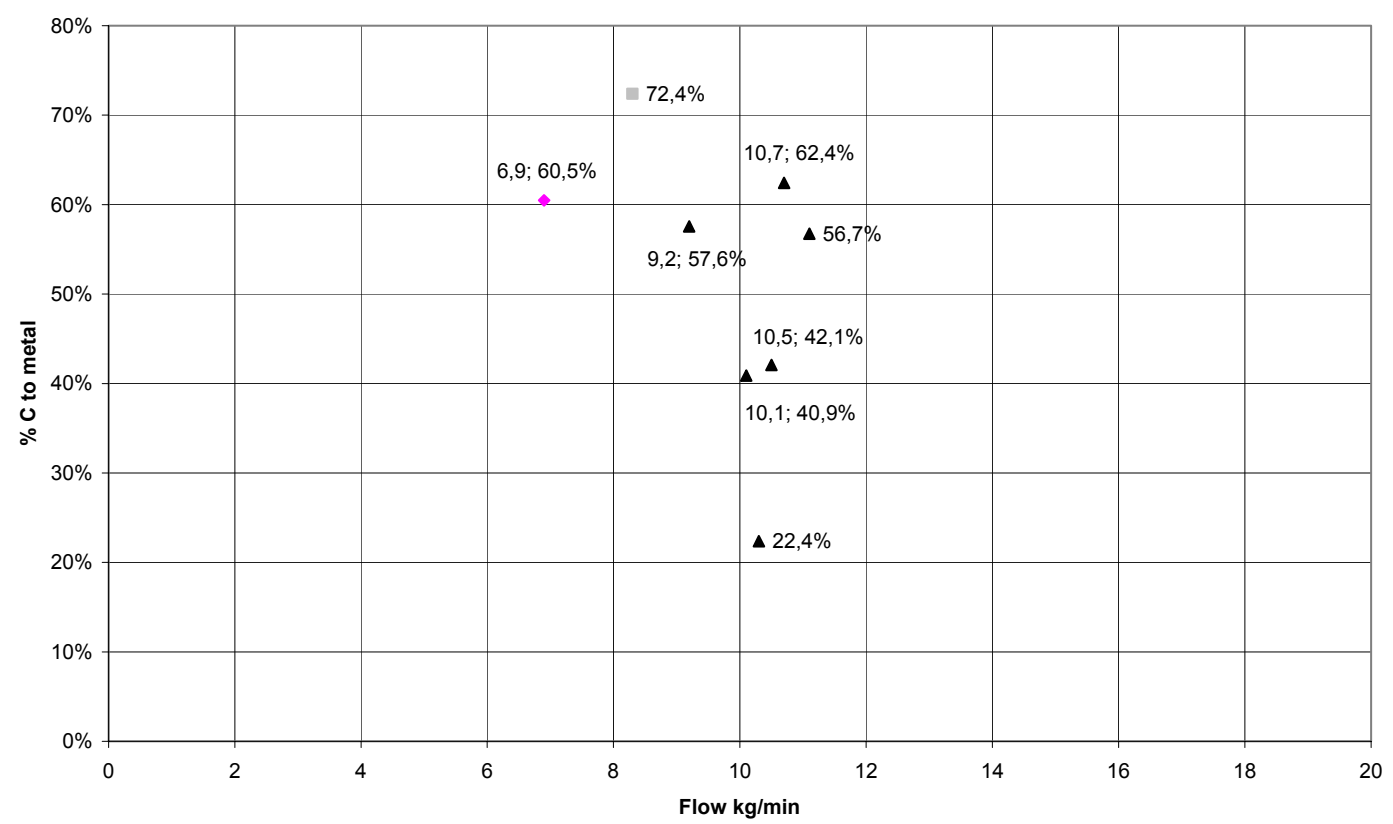

Figure 15 - C yield for coke injection

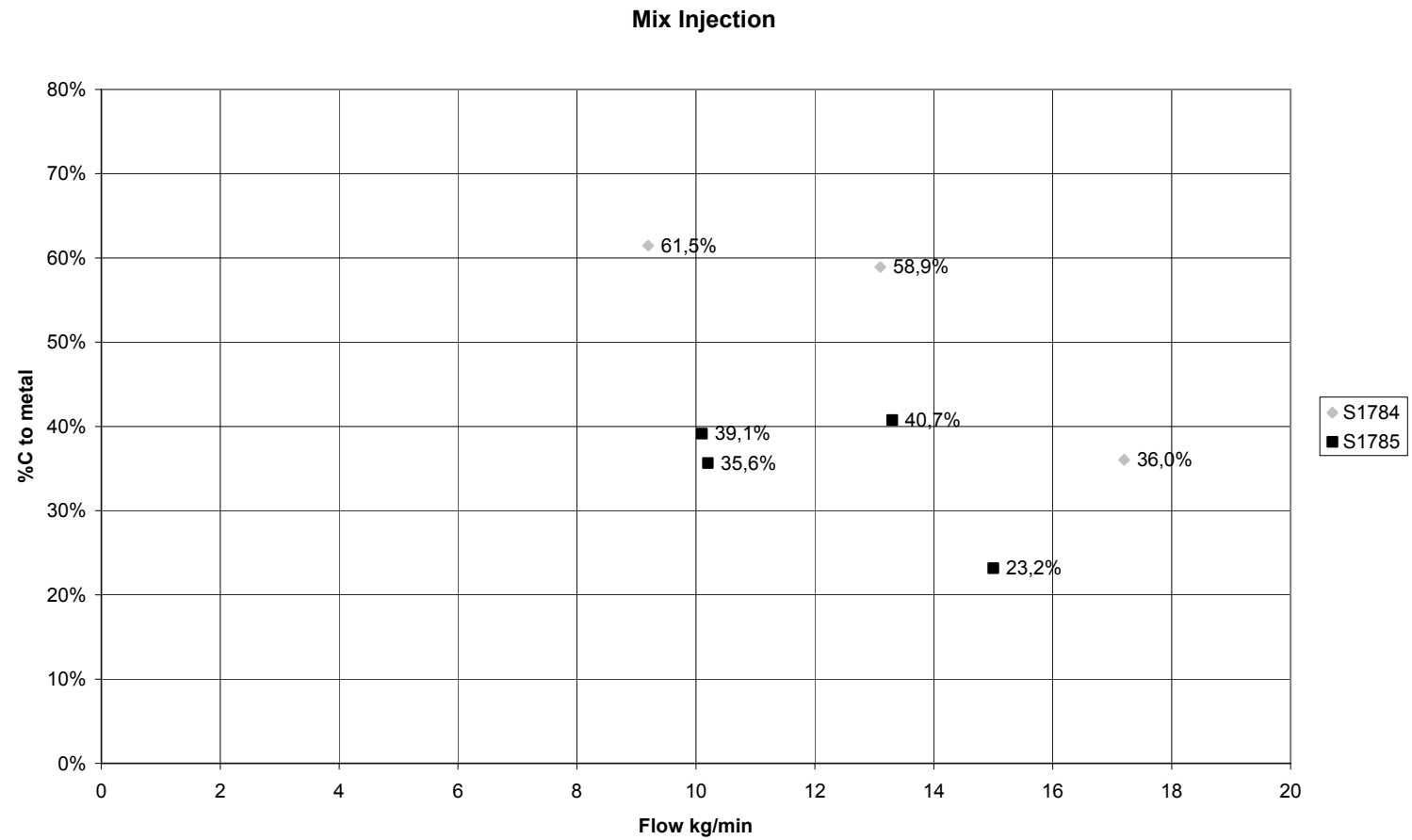

Figure 16 - C yield for coal/coke mix injection 
-AI p50 -

Oil Injection

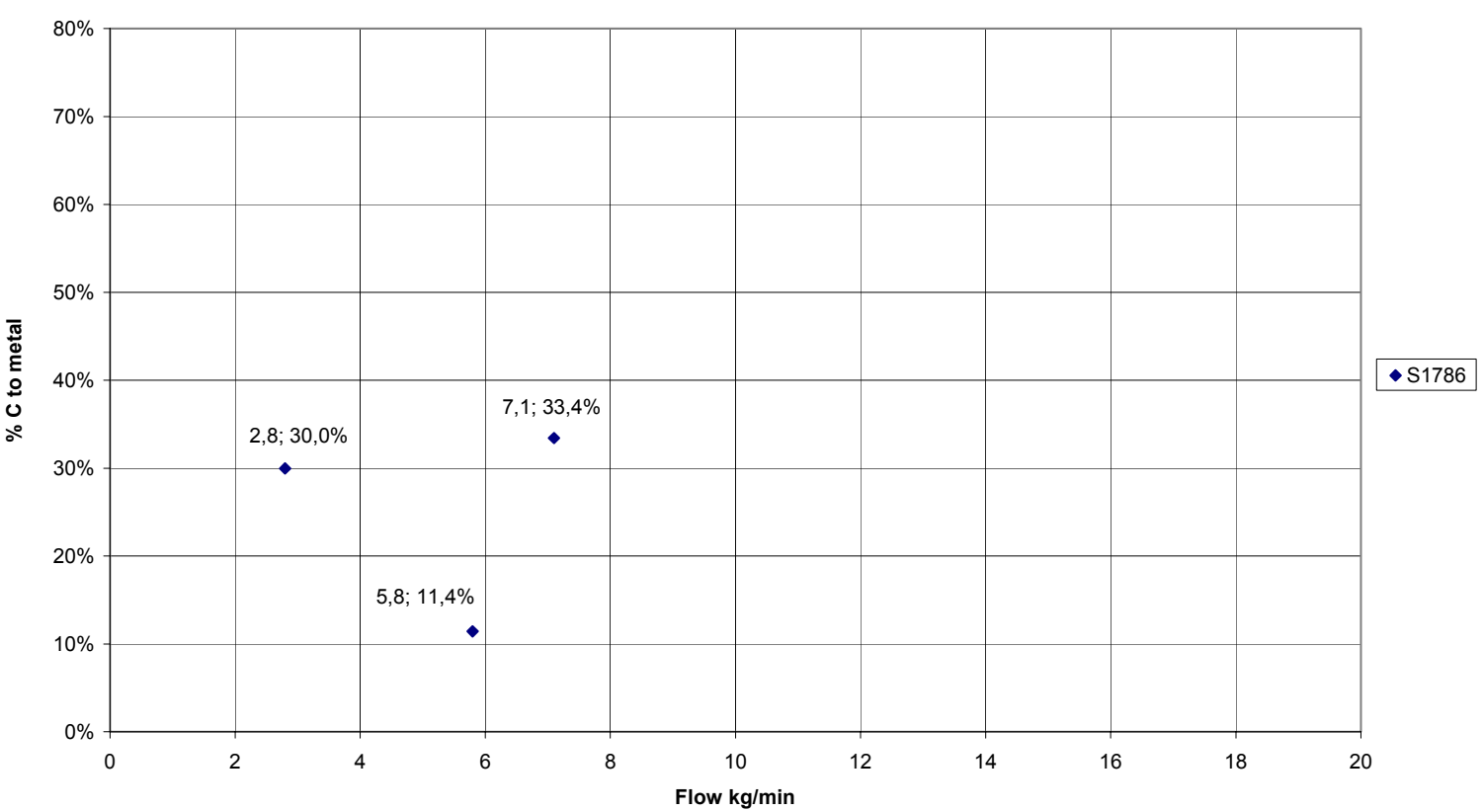

Figure 17 - C yield for oil injection 


\subsection{Vanadium balance}

During HyMelt 6, $80 \mathrm{~kg}$ ferro vanadium was added, equal to $65,5 \mathrm{~kg}$ pure $\mathrm{V}$. As can be seen in the table the vanadium is distributed between metal and slag. The concentration ratio is strongly depending on oxygen potential. The response in metal analysis after addition is higher than expected indicating some error in the background data for calculation.

Table 1 - Vanadium balance data

\begin{tabular}{|c|c|c|c|c|c|c|c|c|c|}
\hline \multirow{2}{*}{ Time } & \multirow{2}{*}{\multicolumn{2}{|c|}{$\begin{array}{l}\text { Metal } \\
\text { Weight kg } \mid \% \mathrm{C}\end{array}$}} & \multirow[b]{2}{*}{$\% \mathrm{~V}$} & \multirow{2}{*}{$\begin{array}{l}\text { Slag } \\
\% \mathrm{Fe}\end{array}$} & \multirow[b]{2}{*}{$\% \mathrm{CaO}$} & \multirow[b]{2}{*}{$\% \mathrm{SiO} 2$} & \multirow[b]{2}{*}{$\%$ V2O5 } & \multirow{2}{*}{\begin{tabular}{|l|} 
Calculation \\
$\mathrm{CaO} / \mathrm{SiO} 2$
\end{tabular}} & \multirow{2}{*}[\mathrm{V}2\mathrm{O}5]{$/(\mathrm{V})$} \\
\hline & & & & & & & & & \\
\hline $11: 25$ & 5376 & 1,06 & $\begin{array}{l}0,051 \\
\end{array}$ & 6,06 & 37,82 & 21,09 & 0,15 & 1,79 & 2,94 \\
\hline $12: 12$ & 5331 & Addition & $f^{\prime} 80 \mathrm{~kg} \mathrm{Fel}$ & $(81,88 \% \mathrm{~V})$ & & & & & \\
\hline $12: 55$ & 5207 & 2,98 & 1,573 & 18,65 & 9,67 & 24,32 & 0,89 & 0,40 & 0,57 \\
\hline 13:44 & 5082 & 2,16 & 0,5 & 3,3 & 39,4 & 20,47 & 11,14 & 1,93 & 21,97 \\
\hline $14: 23$ & 5082 & 2,27 & 0,744 & 4,09 & 36,24 & 26,72 & 6,00 & 1,36 & 8,06 \\
\hline
\end{tabular}

\subsection{Hydrogen purging}

During HyMelt 6 hydrogen was purged trough the bottom tuyere for 17 minutes. The purpose was to investigate the possibility to remove $\mathrm{S}$ to the gas phase.

Before gas purging

Metal $0,8 \% \mathrm{~S}$

Slag $5,74 \% \mathrm{~S}$

After gas purging

Metal $0,60 \% \mathrm{~S}$

Slag $4,81 \% \mathrm{~S}$

About $12 \mathrm{~kg}$ sulphur has been removed from metal and slag. This corresponds to $44 \%$ efficiency if creation of $\mathrm{H}_{2} \mathrm{~S}$ is assumed. However, this can not be confirmed by the gas analysing. Further studies must be made to fully understand the chemical mechanisms.

\subsection{Dust analysis}

\subsubsection{Dust sampled from process gas}

Dust from the ceramic filter have been analysed, the results are shown in Appendix 5.

Label "Prov K7" refers to coal injection

Label "Prov K21" refers to oil injection

Label "Prov K25" refers to coke injection

The lab has problem to determine carbon because of the small sample amount. 


\subsubsection{Dust sampled from combusted gas}

Estimation by iso-kinetic sampling of the dust load has been made from the injection periods, Appendix 6. The results show a load less than $10 \mathrm{gram} / \mathrm{m}^{3} \mathrm{n}$ dry gas in average.

Three samples have been analysed and the result are presented in Appendix 7.

Label "Prov 7" refers to coal injection

Label "Prov 21" refers to oil injection

Label "Prov 25" refers to coke injection

The lab has problem to determine carbon because of the small sample amount.

\subsection{Mercury in process gas}

Three samples for mercury determination in the process gas have been analysed, Appendix 8, The result differs very much in spite of that all three samples refers to coal injection. Obviously there are severe problems with the procedure and must be drastically improved. In future it will be necessary to have one dedicated suction line for the mercury sampling.

"Prov 1", "Prov2" and "Prov 3" are sampled liquids while "Prov 0" is a reference on clean liquid.

\subsection{Refractory wear}

The converter lining was measured before and after the campaign. As can be seen in the table no severe wear has occurred. Typical erosion in the level of the slag can be seen.

Table 2 - Lining wear

\begin{tabular}{|c|cc|cc|c|}
\hline & New lining & & \multicolumn{2}{|c|}{ After HyMelt 6 } & Wear \\
Level & N/S & E/W & N/S & E/W & \\
\hline Cone & 1410 & 1410 & 1360 & 1420 & -10 \\
1500 & 1410 & 1410 & 1440 & 1440 & 15 \\
1250 & 1410 & 1410 & 1460 & 1460 & 25 \\
1000 & 1410 & 1410 & 1460 & 1460 & 25 \\
750 & 1410 & 1410 & 1450 & 1460 & 23 \\
500 & 1410 & 1410 & 1480 & 1470 & 33 \\
250 & 1410 & 1410 & 1500 & 1460 & 35 \\
0 & 1410 & 1410 & 1423 & 1413 & 4 \\
\hline Hight & 2893 & & 2990 & & 97 \\
\hline
\end{tabular}

The lining can stand a wear up to $150 \mathrm{~mm}$ and can consequently be used for further campaigns. Minor repair work will be necessary on local spots. 


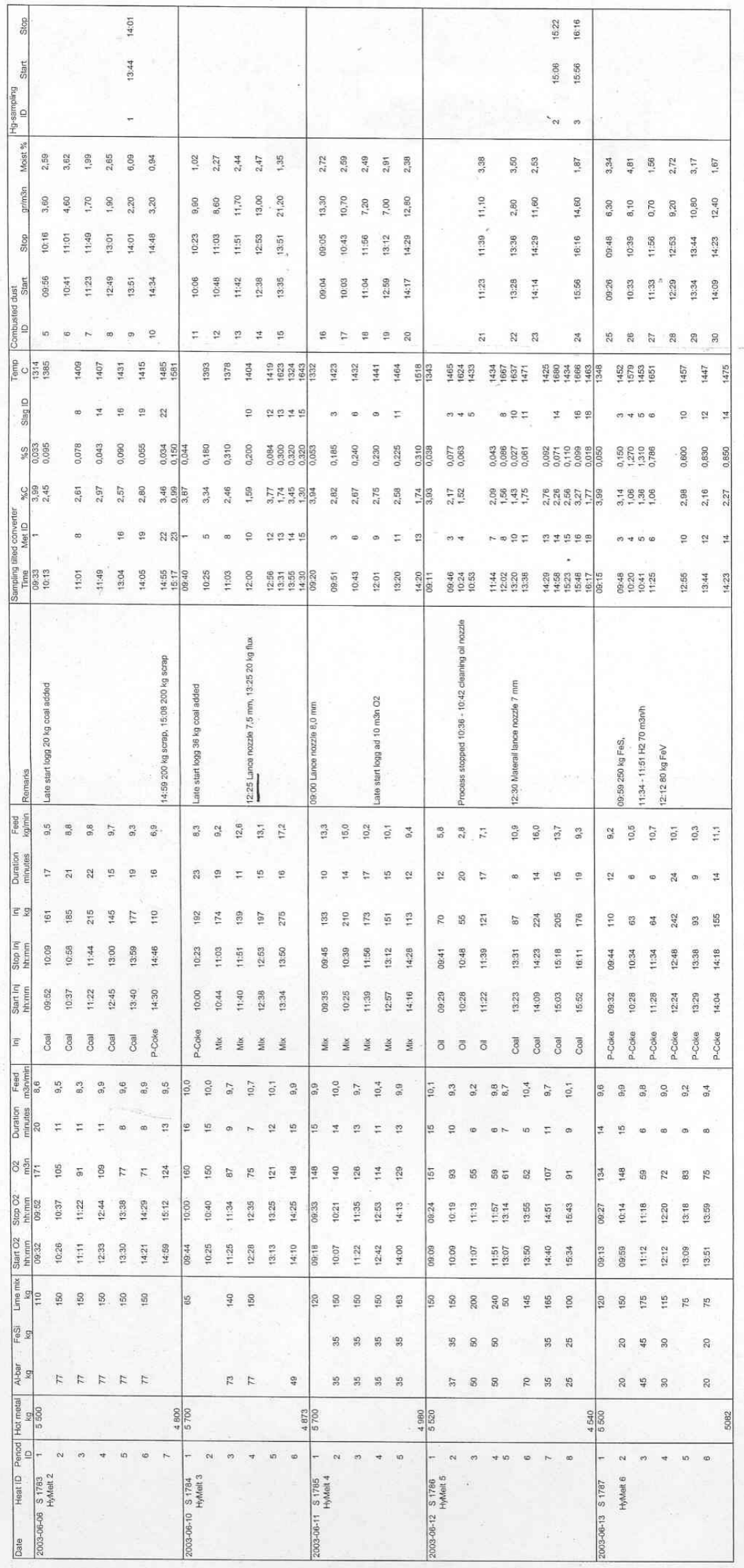


$\mathrm{CO}$ gas analysis

$\mathrm{S} 1783 \% \mathrm{CO}$

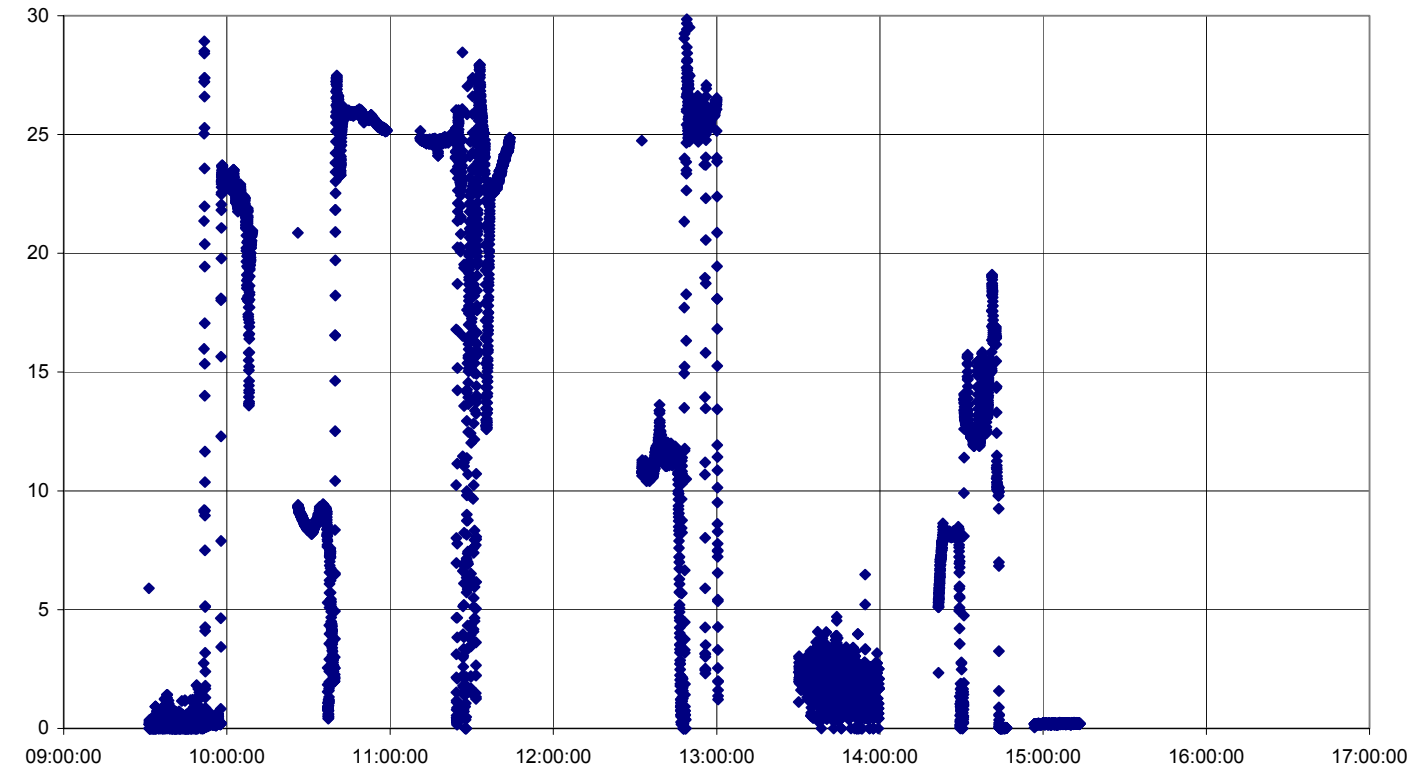

S1784 \%CO

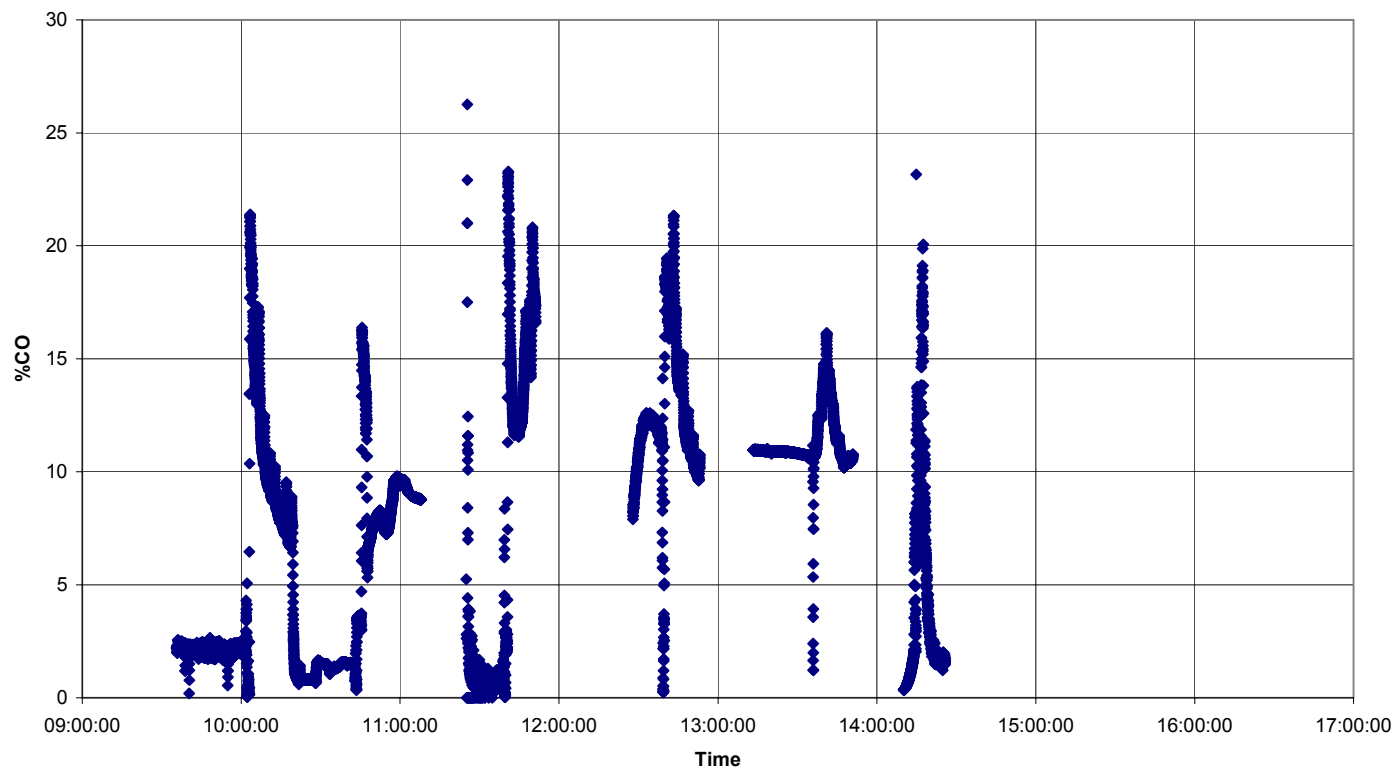


APPENDIX 2

PAGE 2

S $1785 \%$ CO

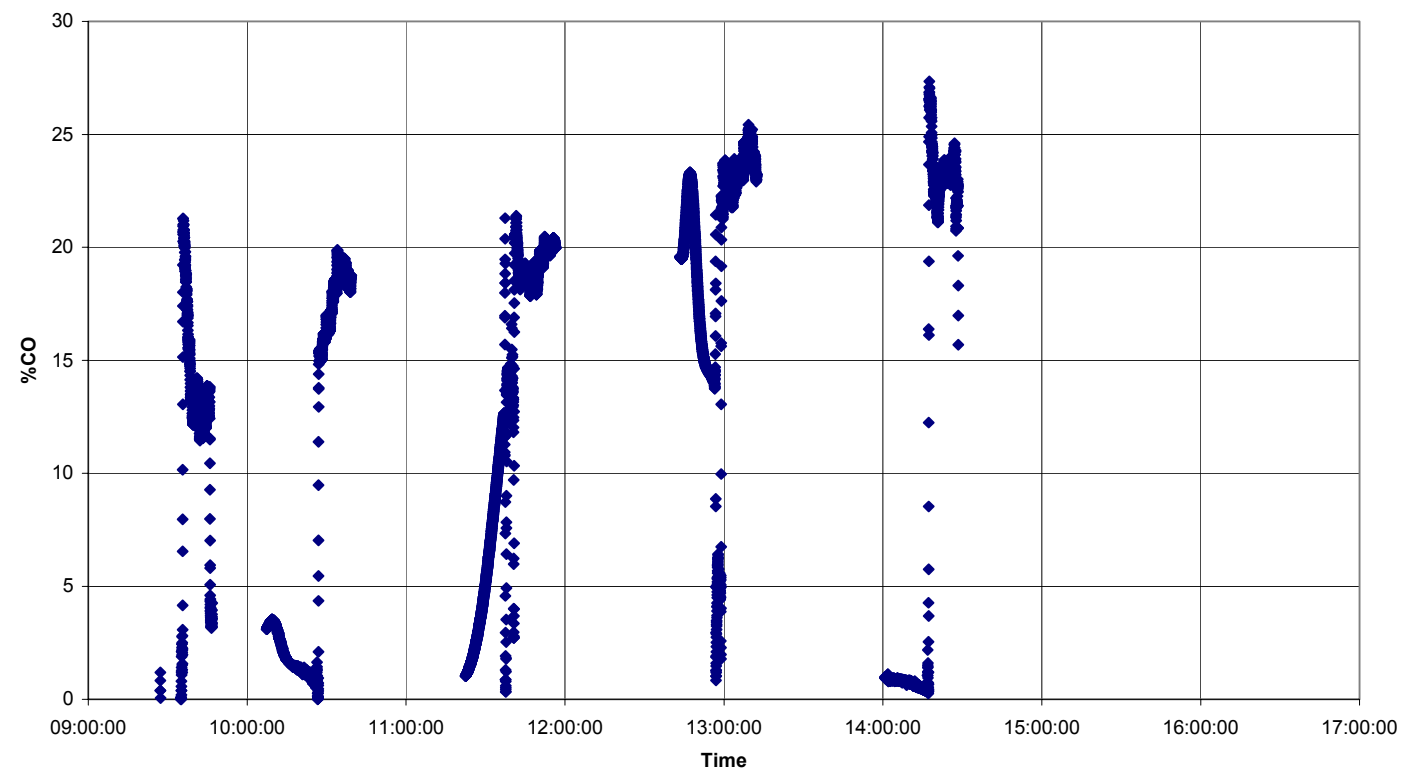

$\mathrm{S} 1786 \% \mathrm{CO}$

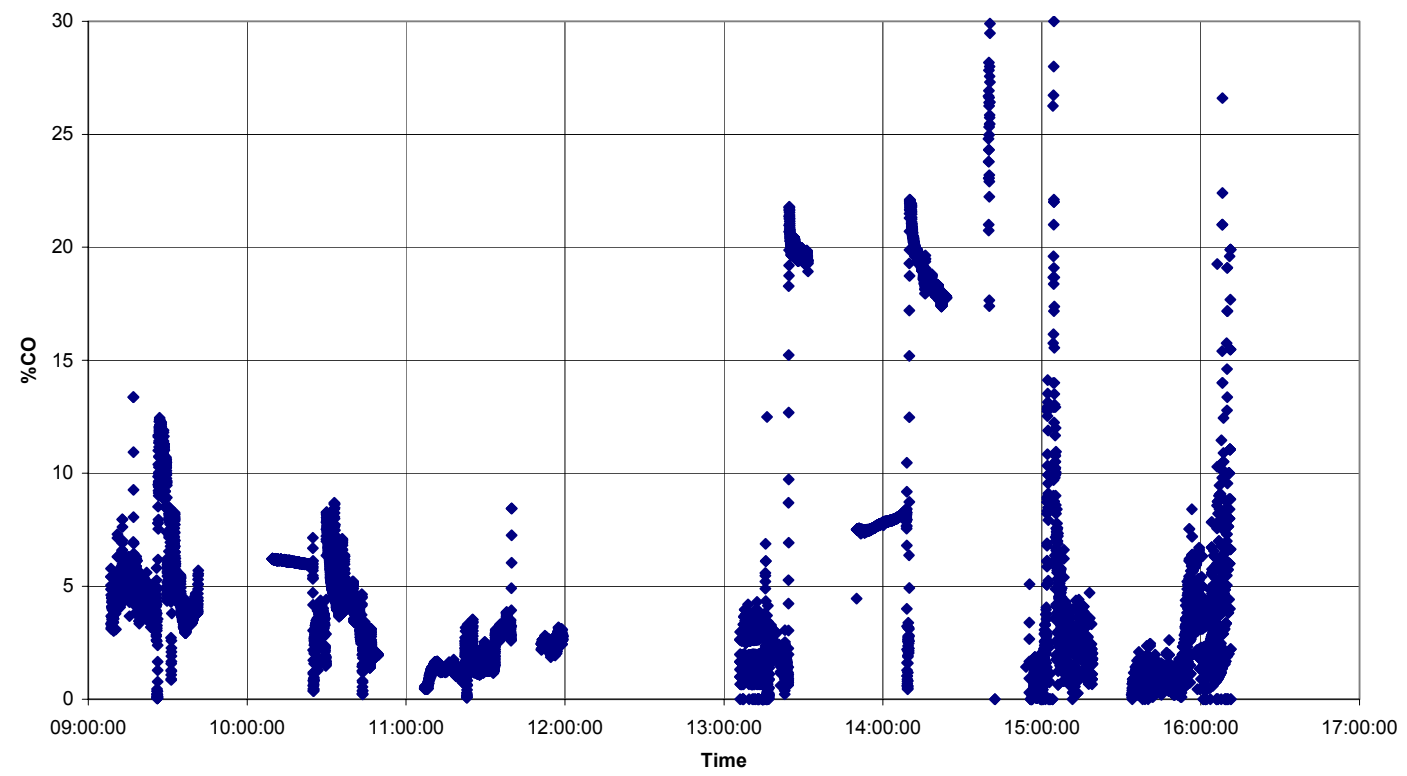


APPENDIX 2

PAGE 3

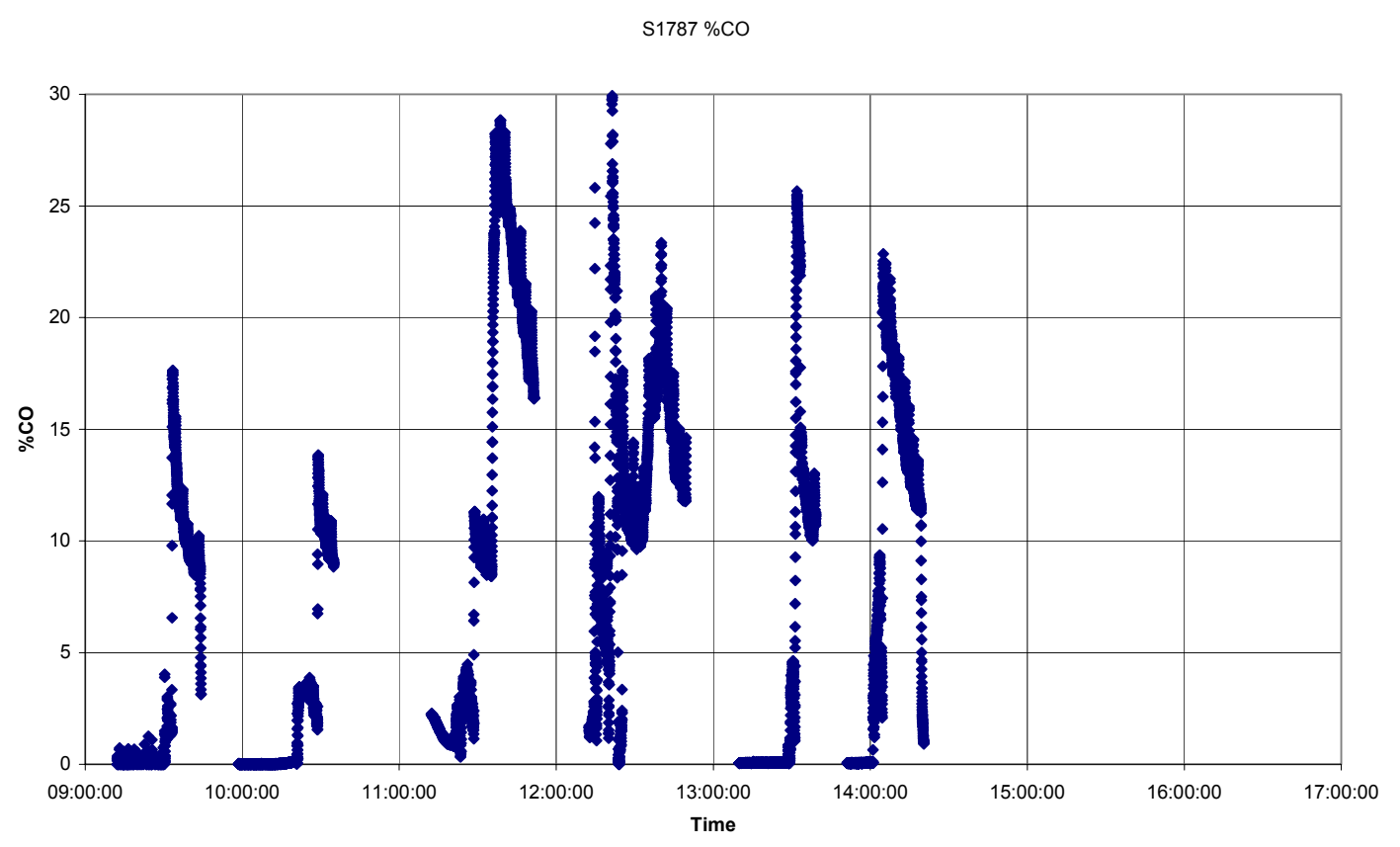


$\mathrm{CO}_{2}$ gas analysis

$\mathrm{S} 1783 \% \mathrm{CO} 2$

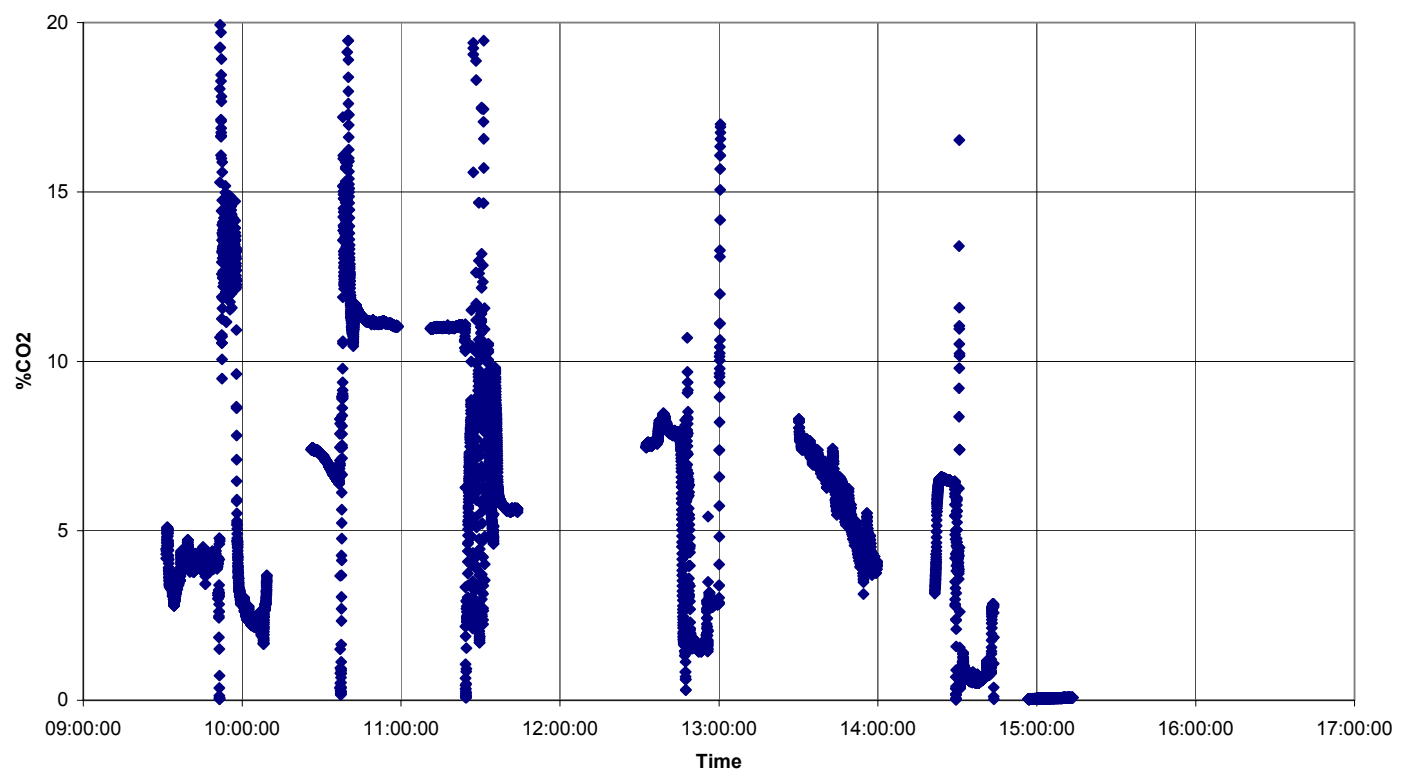

S1784 \%CO2

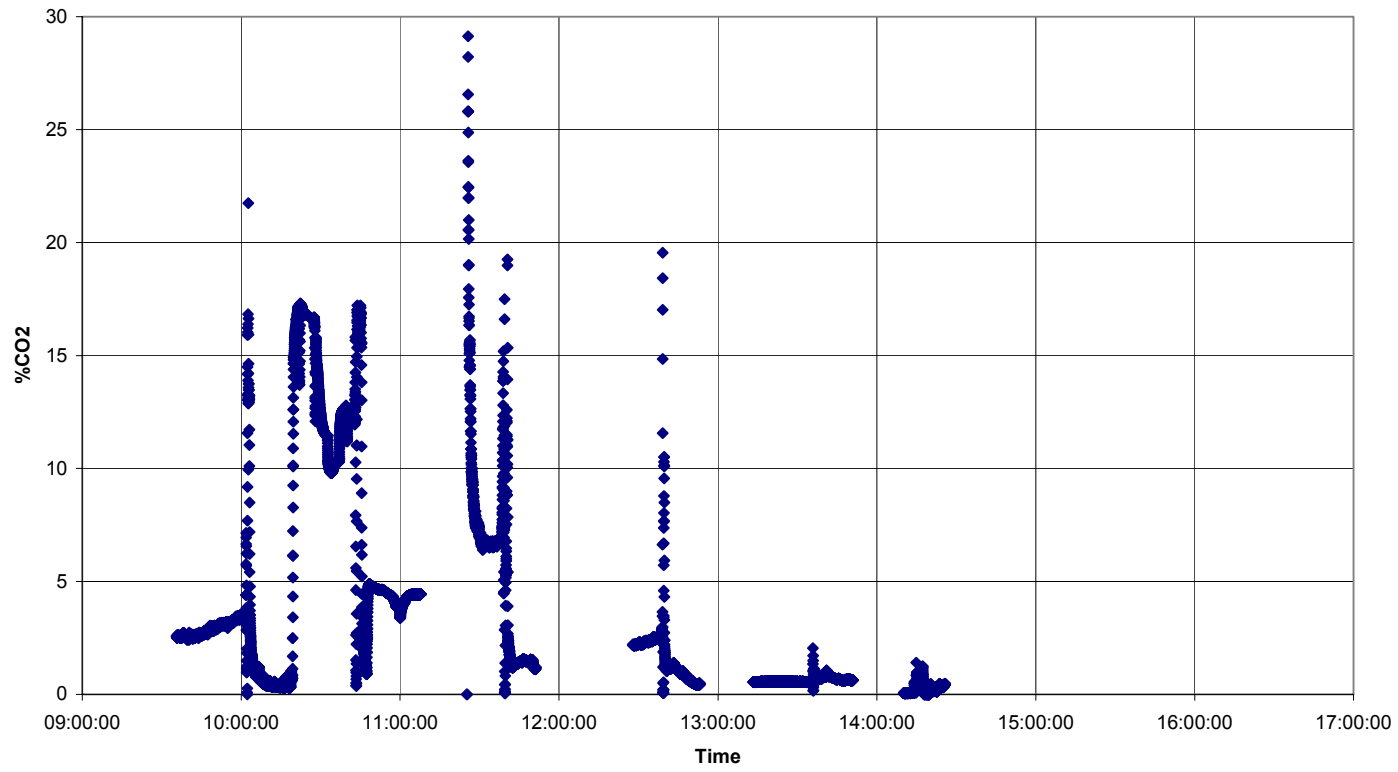


APPENDIX 2

PAGE 5

$\mathrm{S} 1785 \% \mathrm{CO} 2$

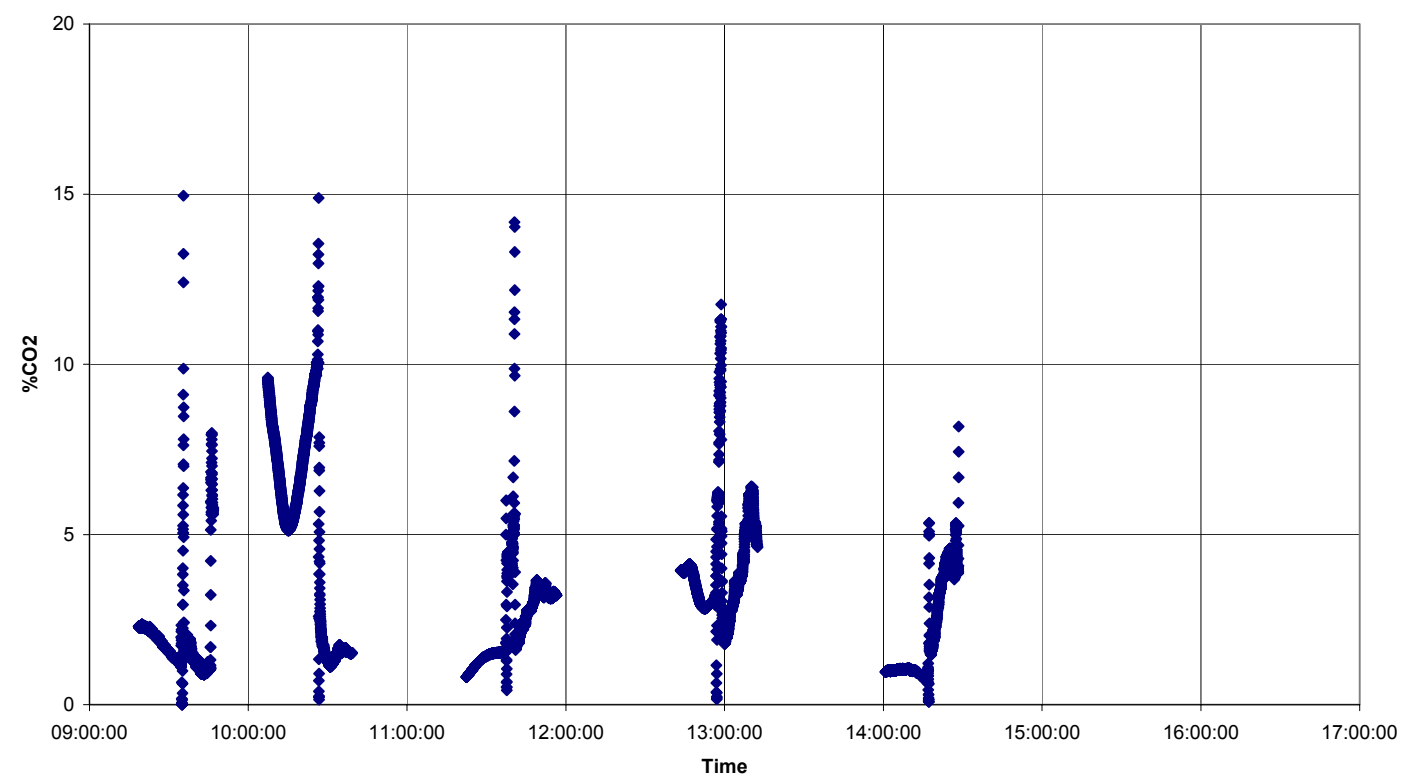

$\mathrm{S} 1786 \% \mathrm{CO} 2$

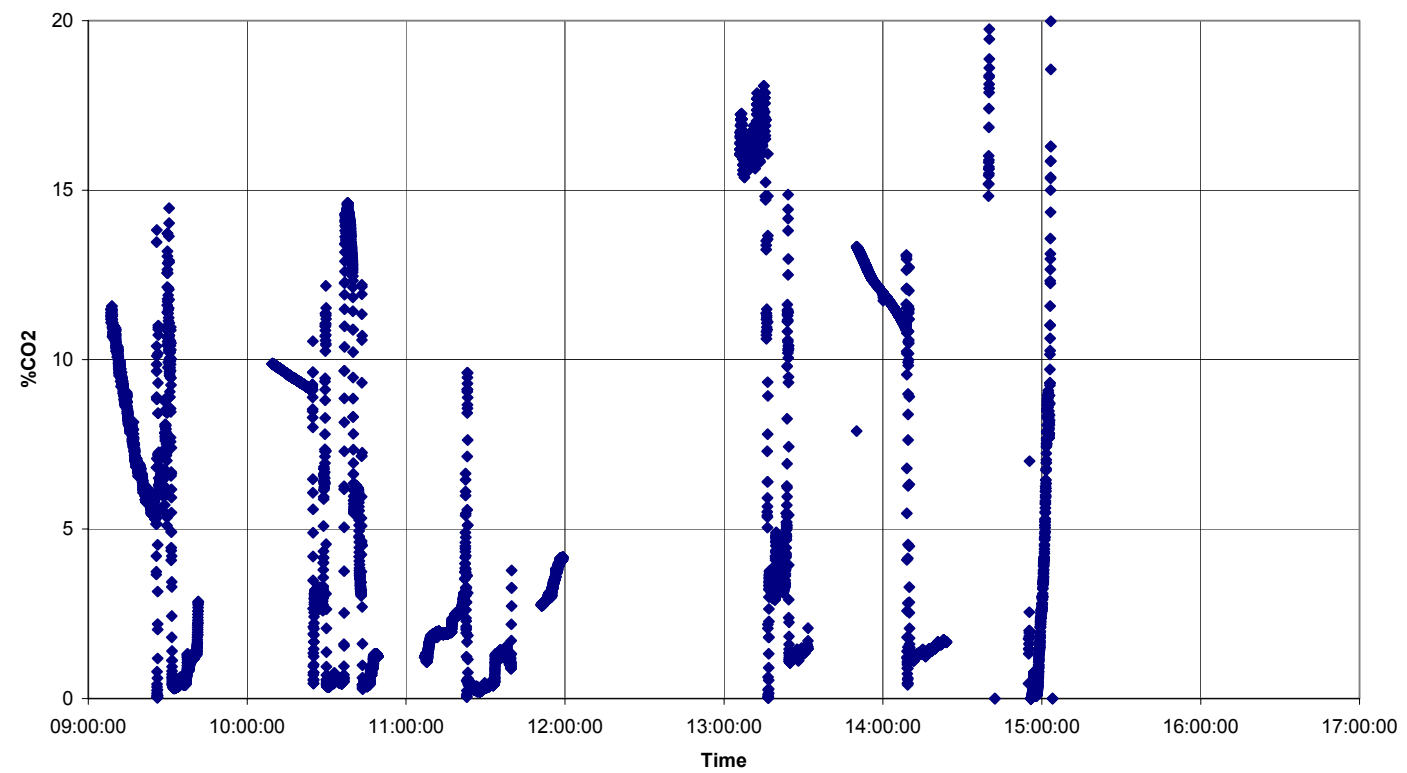


APPENDIX 2

PAGE 6

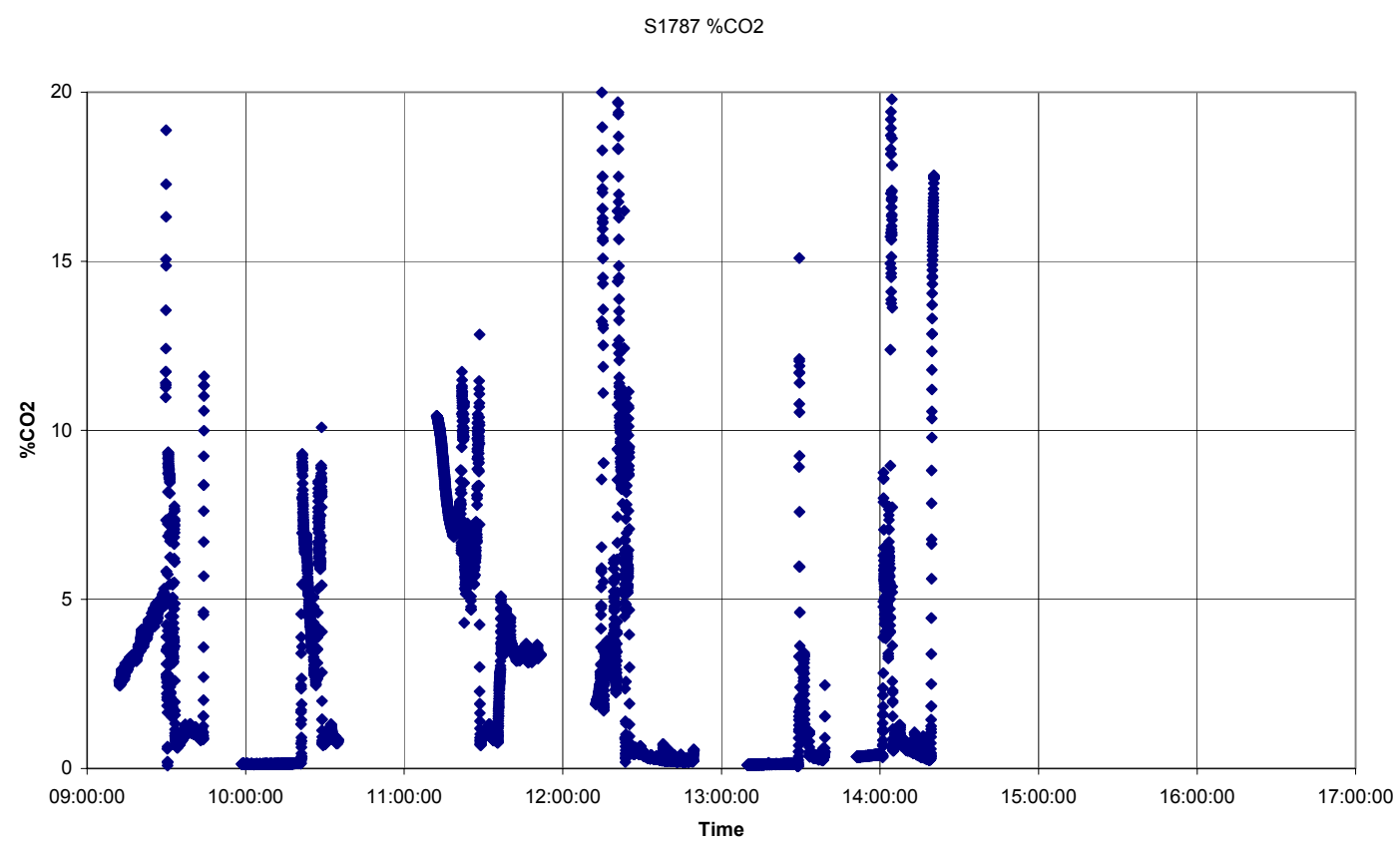


$\mathrm{H}_{2}$ gas analysis

$\mathrm{S} 1783 \% \mathrm{H} 2$

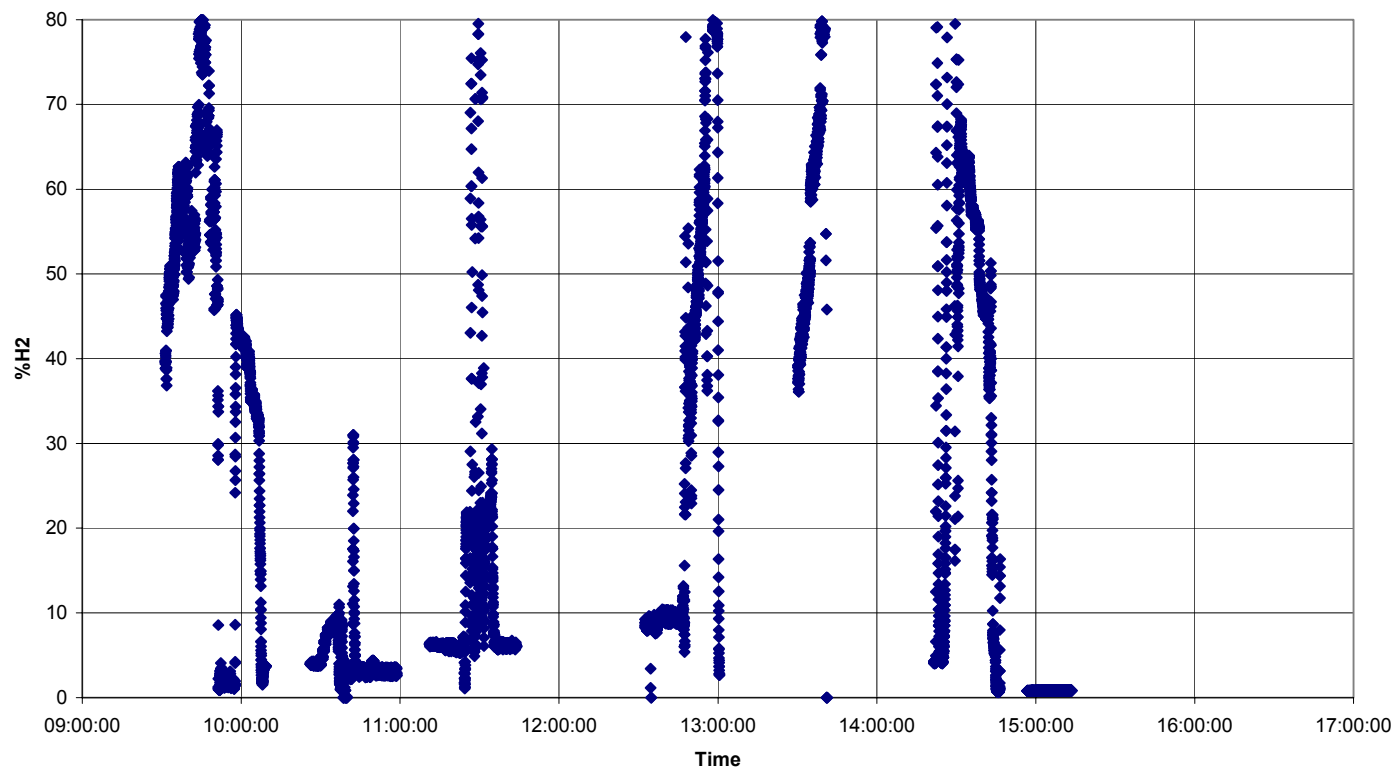

$\mathrm{S} 1784 \% \mathrm{H} 2$

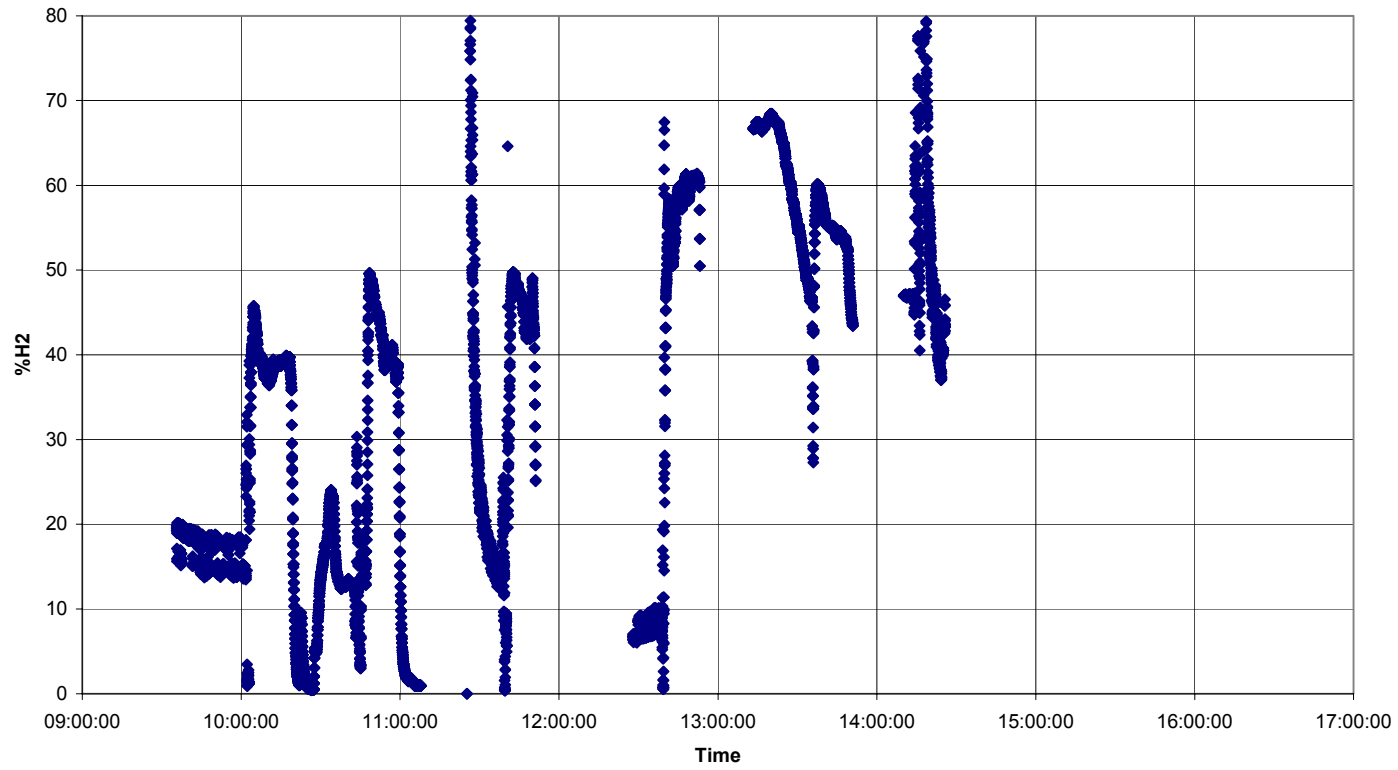


$\mathrm{S} 1785 \% \mathrm{H} 2$

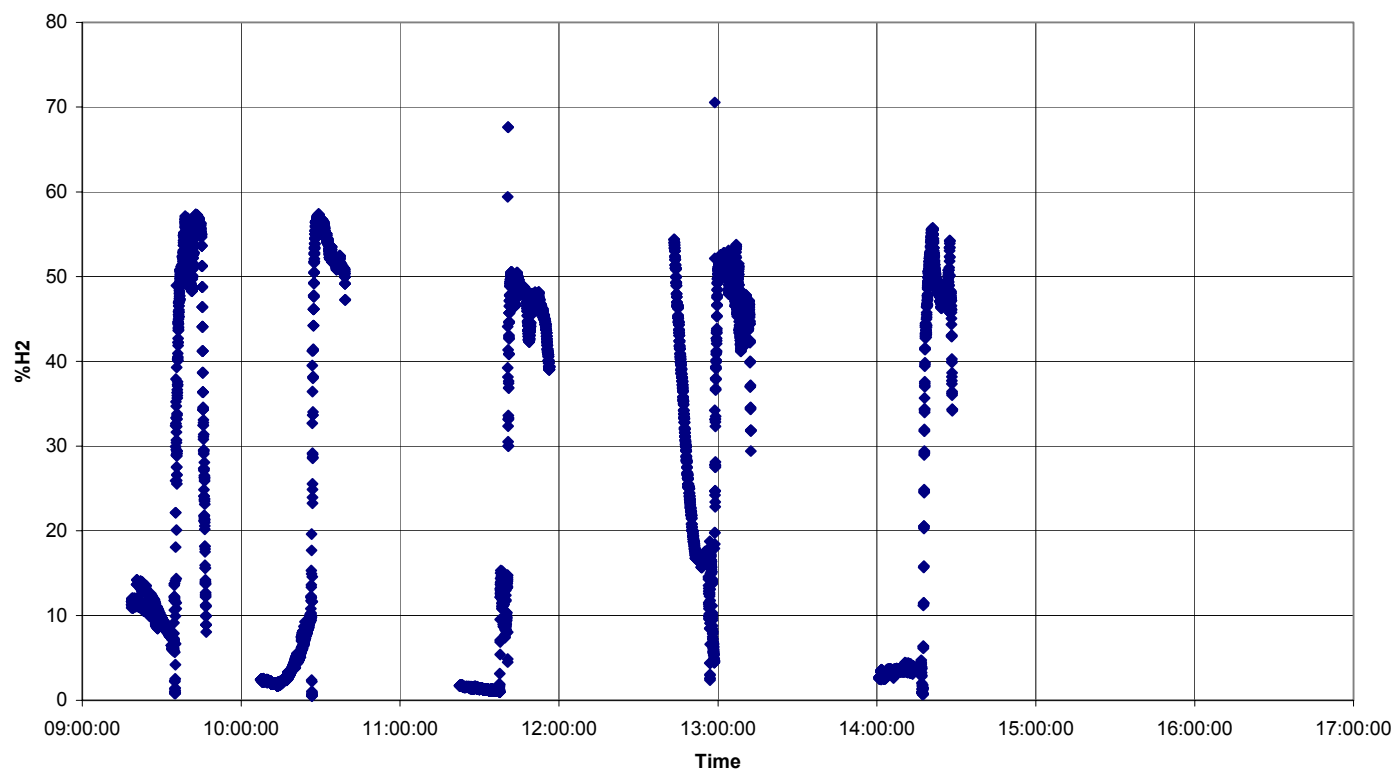

$\mathrm{S} 1786 \% \mathrm{H} 2$

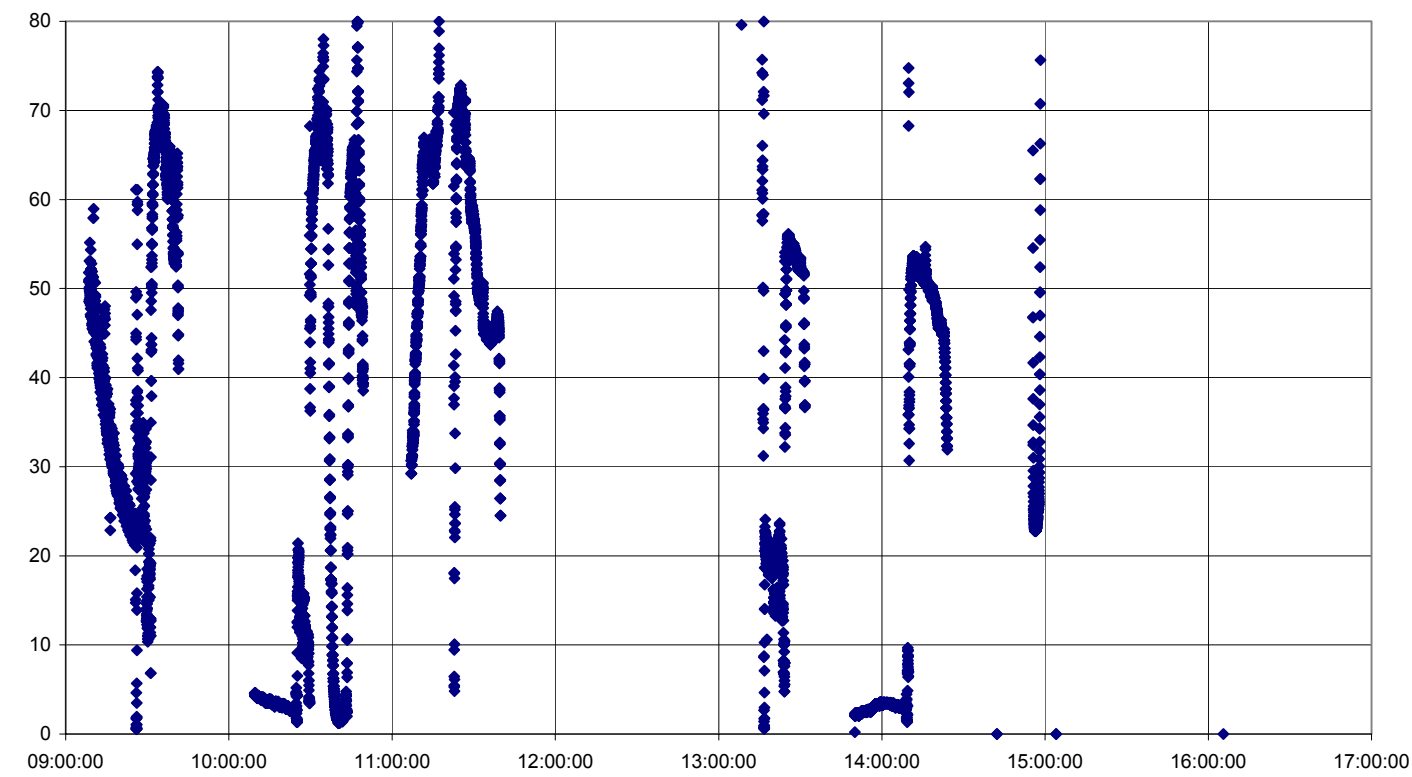


APPENDIX 2

PAGE 9

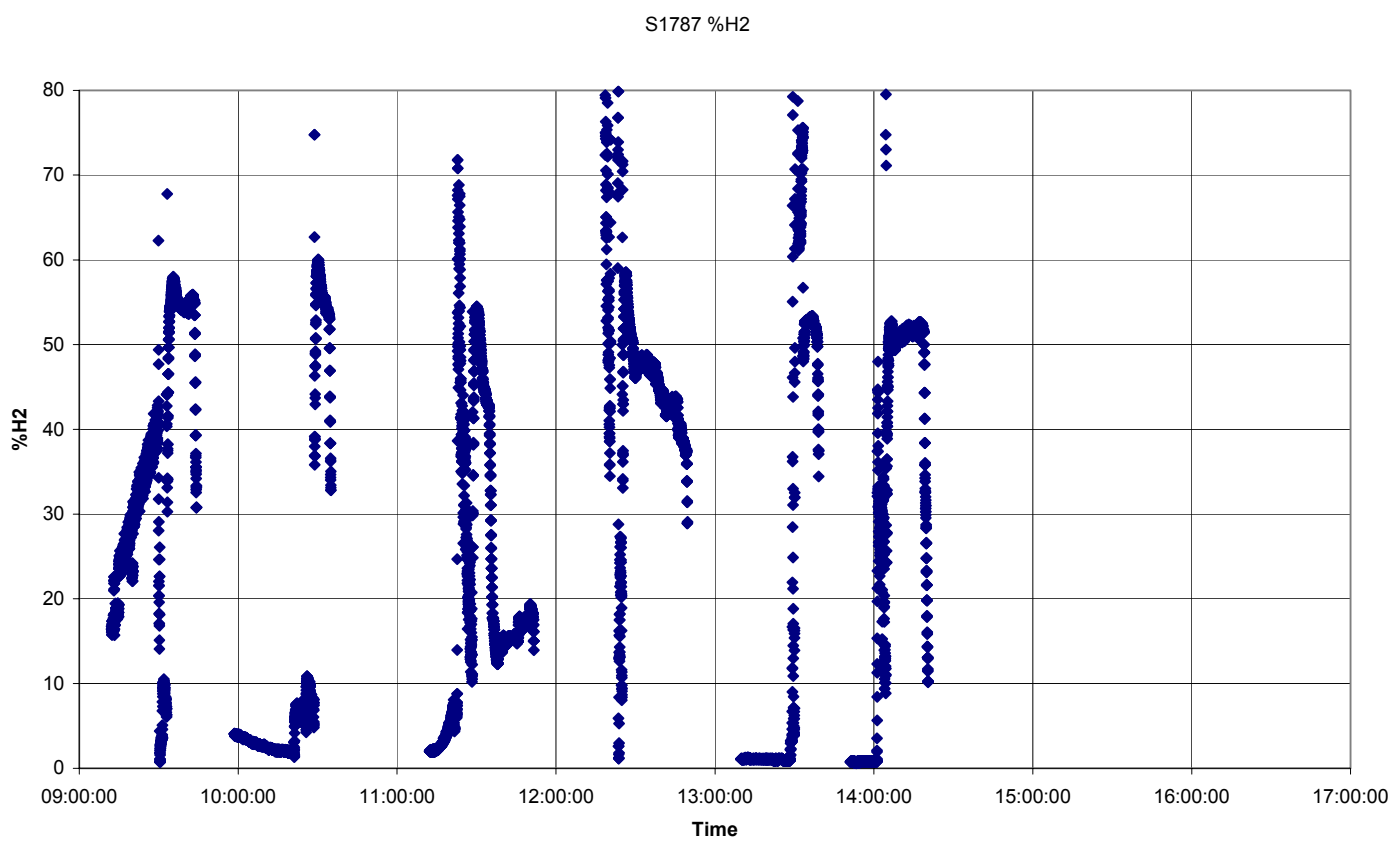


APPENDIX 2

PAGE 10

$\mathrm{CH}_{4}$ gas analysis

S1783 \%CH4

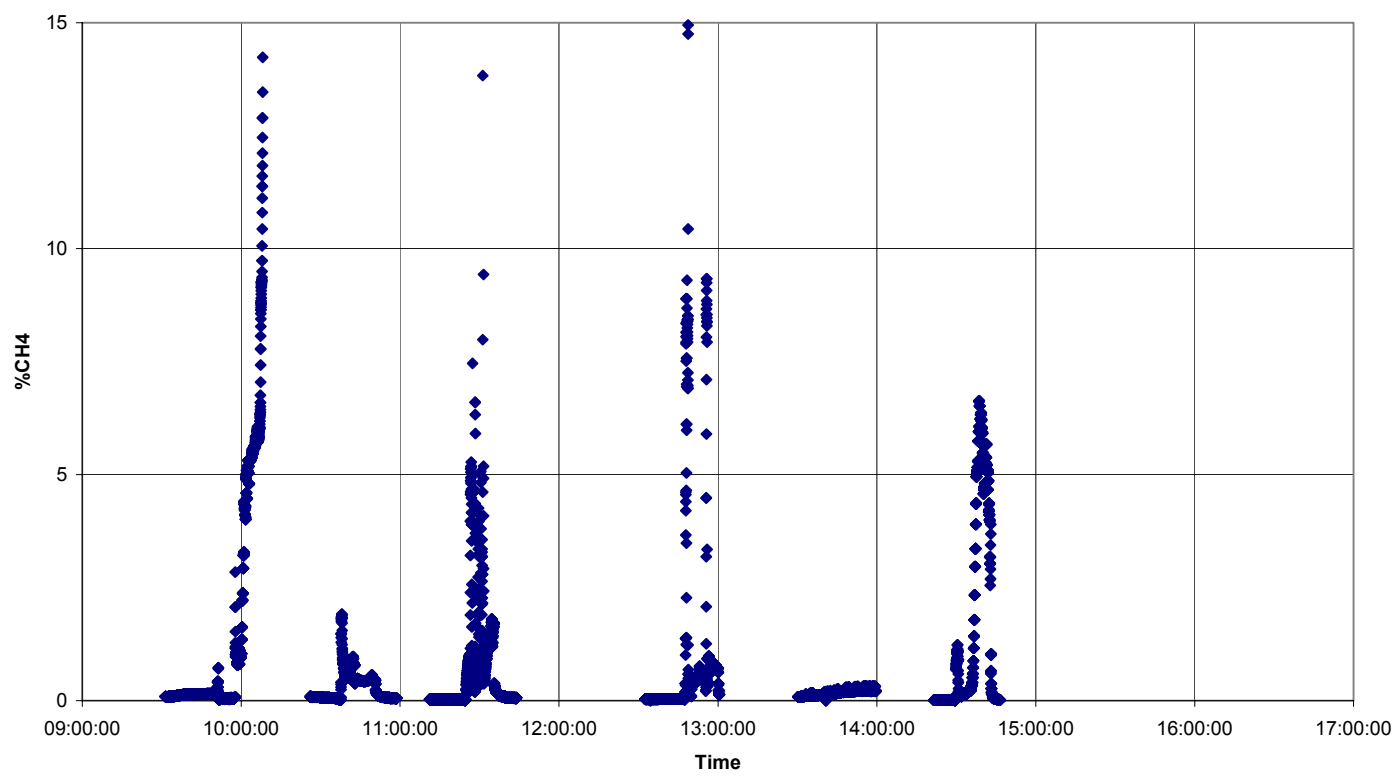

S1784 \%CH4

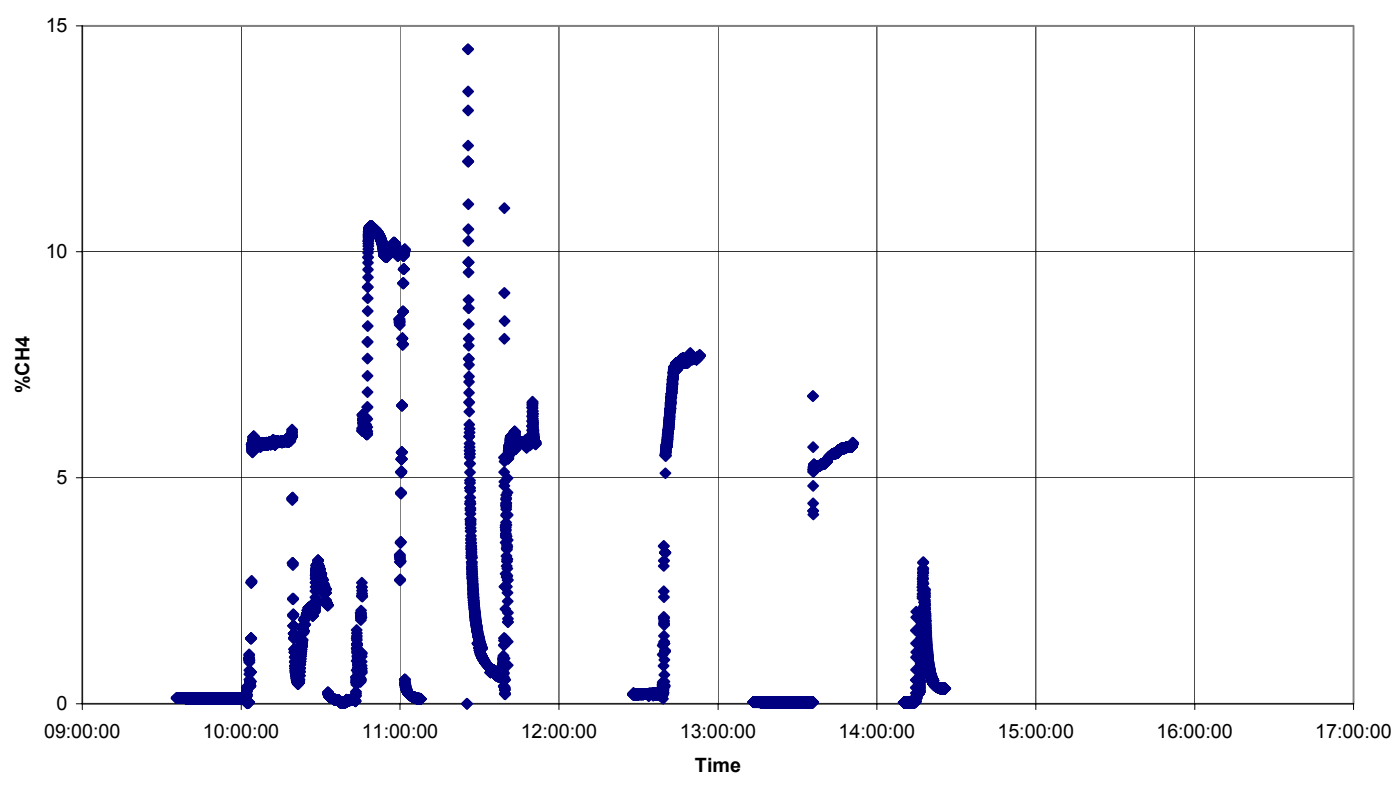


APPENDIX 2

PAGE 11

$\mathrm{S} 1785 \% \mathrm{CH} 4$

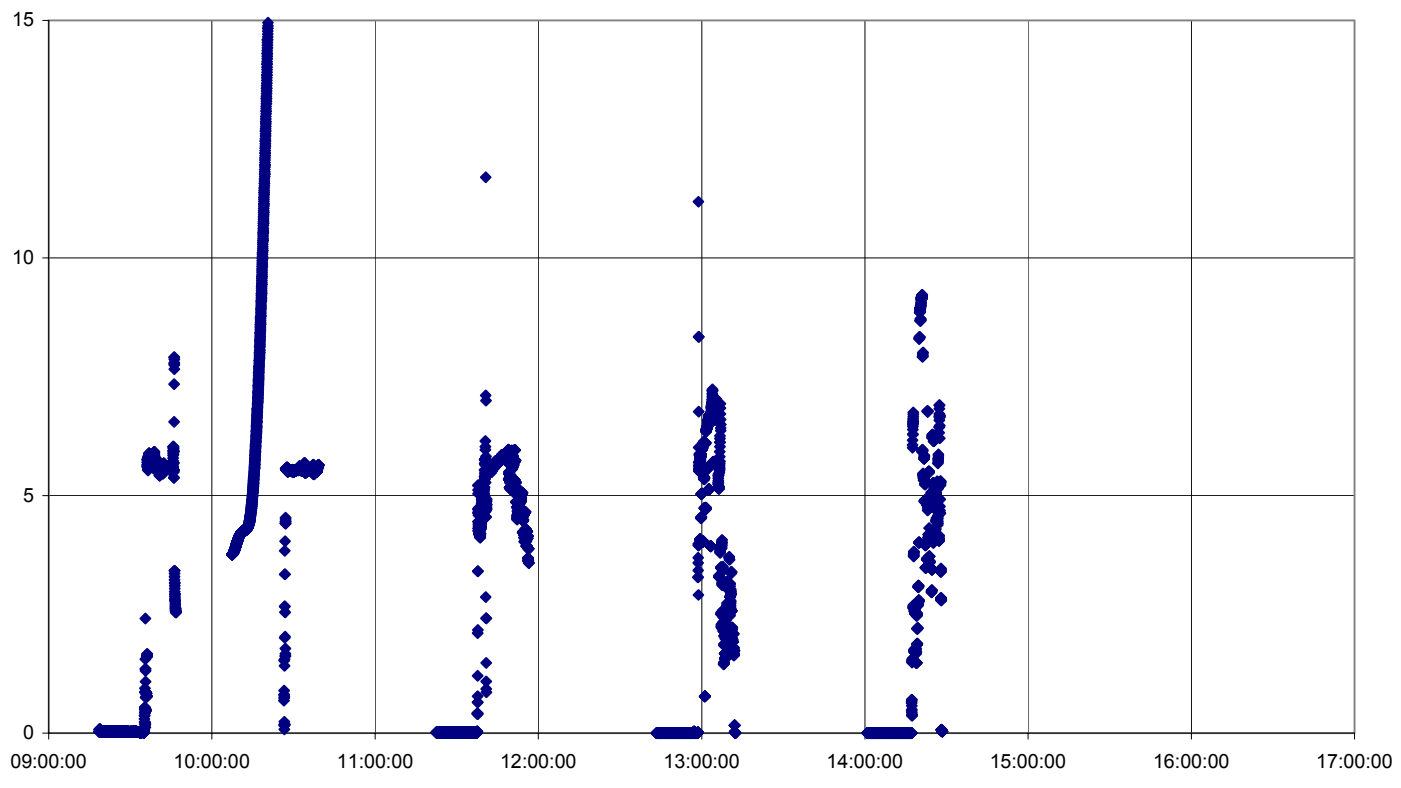

$\mathrm{S} 1786 \% \mathrm{CH} 4$

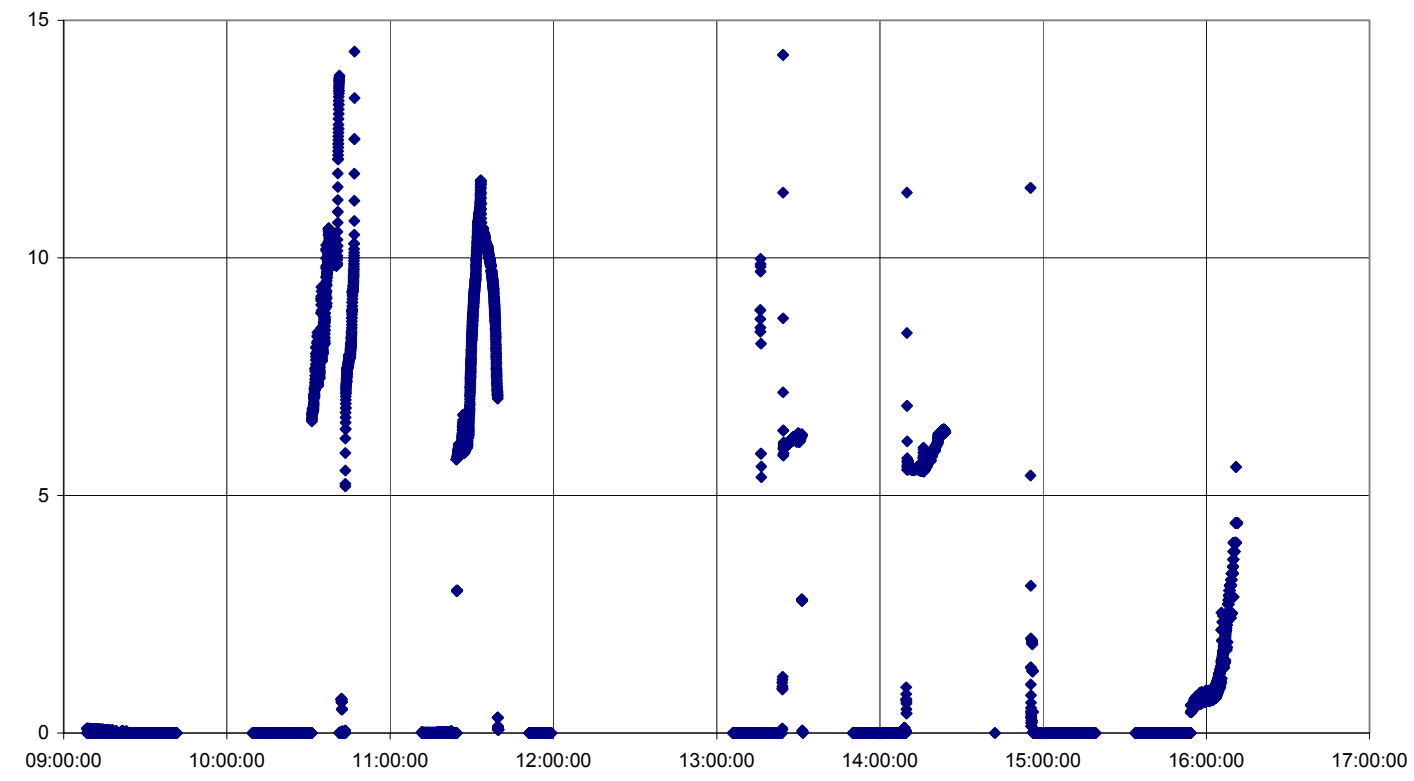


APPENDIX 2

PAGE 12

$\mathrm{S} 1787 \% \mathrm{CH} 4$

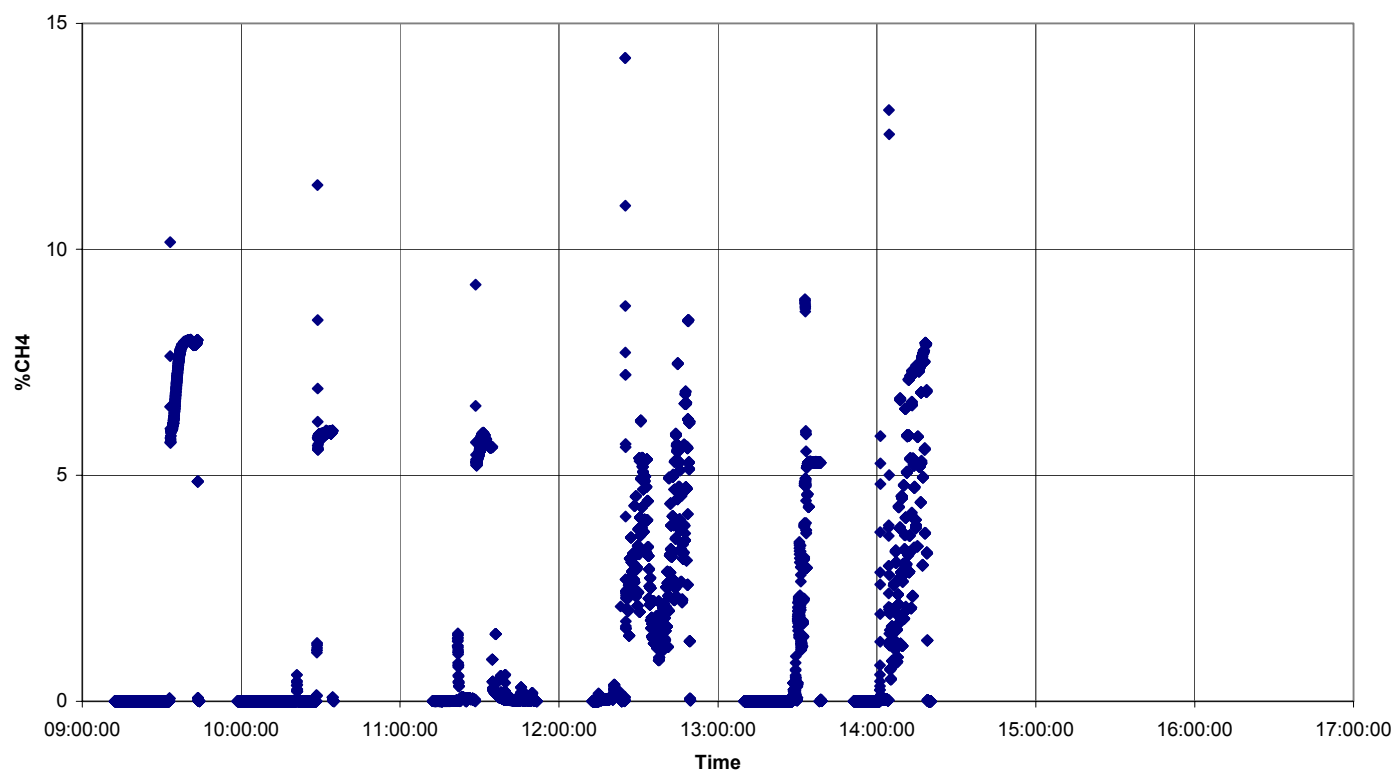


APPENDIX 2

PAGE 13

$\mathrm{H}_{2} \mathrm{~S}$ gas analysis

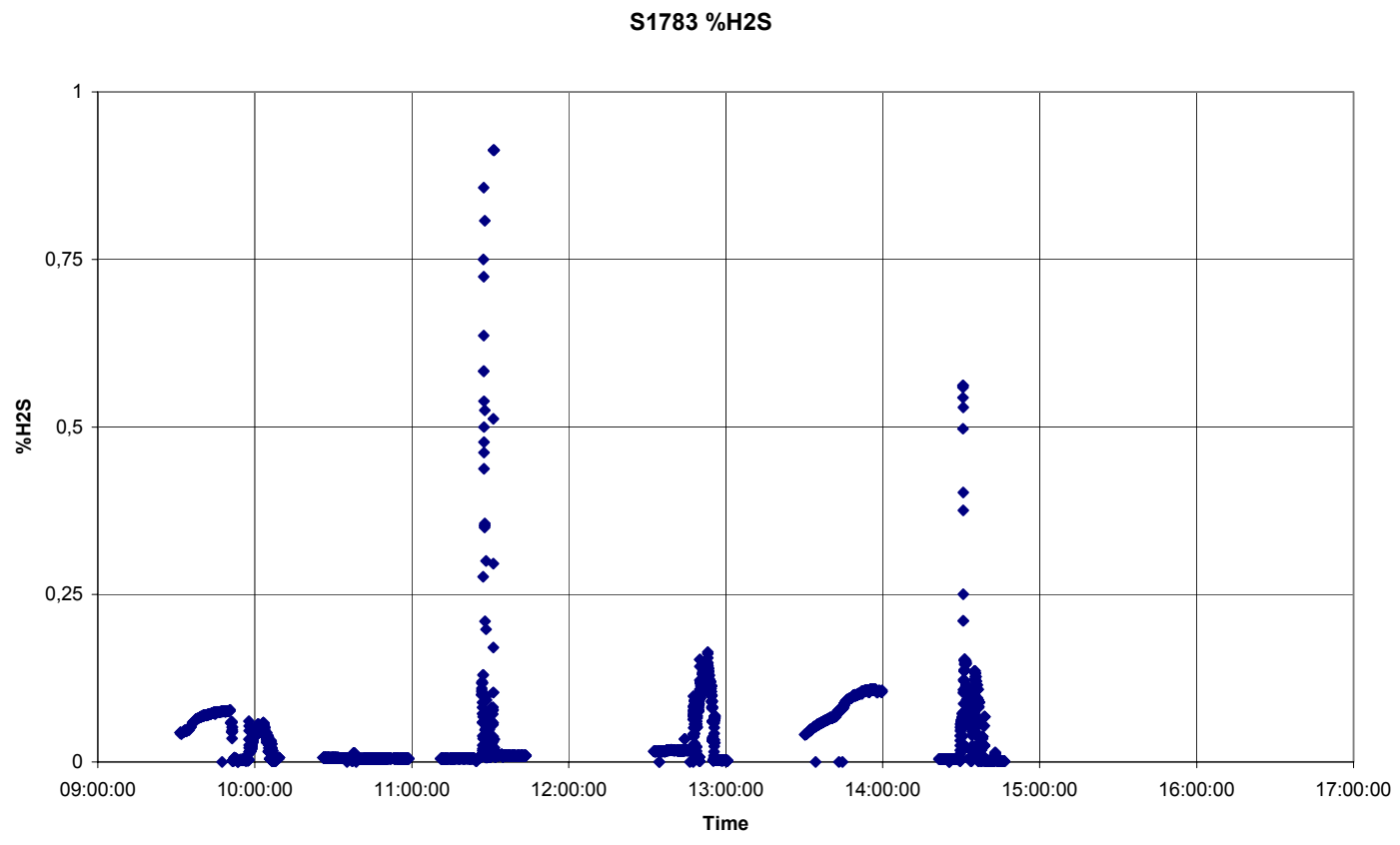

$\mathrm{S} 1784 \% \mathrm{H} 2 \mathrm{~S}$

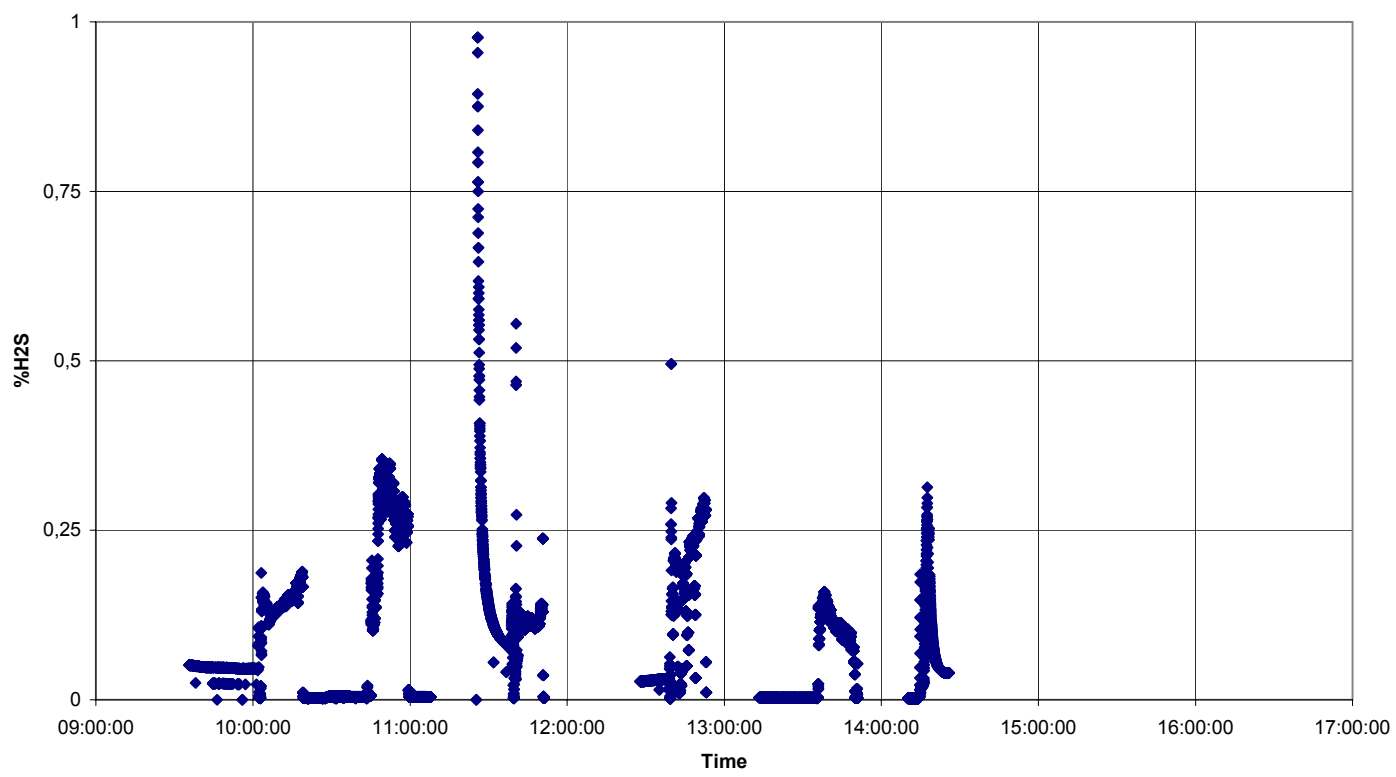


APPENDIX 2

PAGE 14

S1785\%H2S

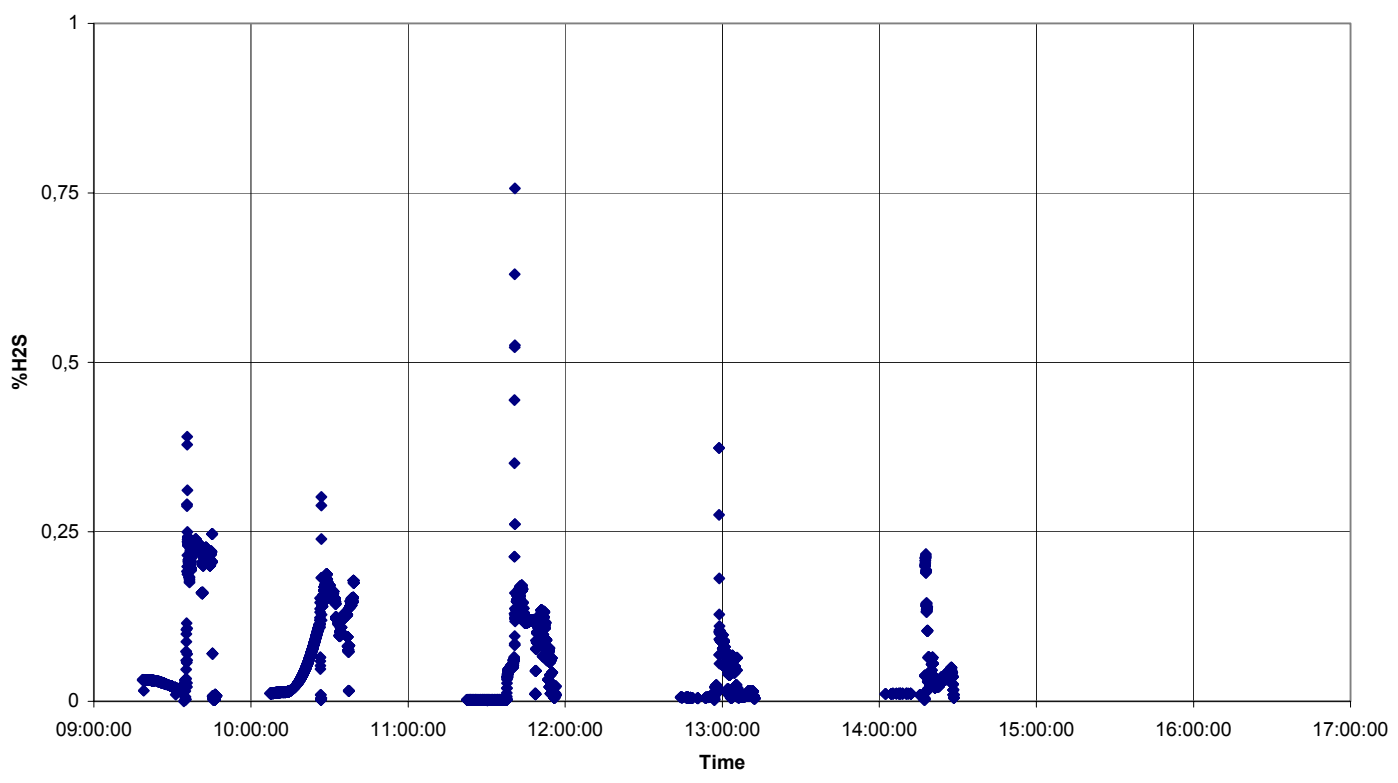

$\mathrm{S} 1786 \% \mathrm{H} 2 \mathrm{~S}$

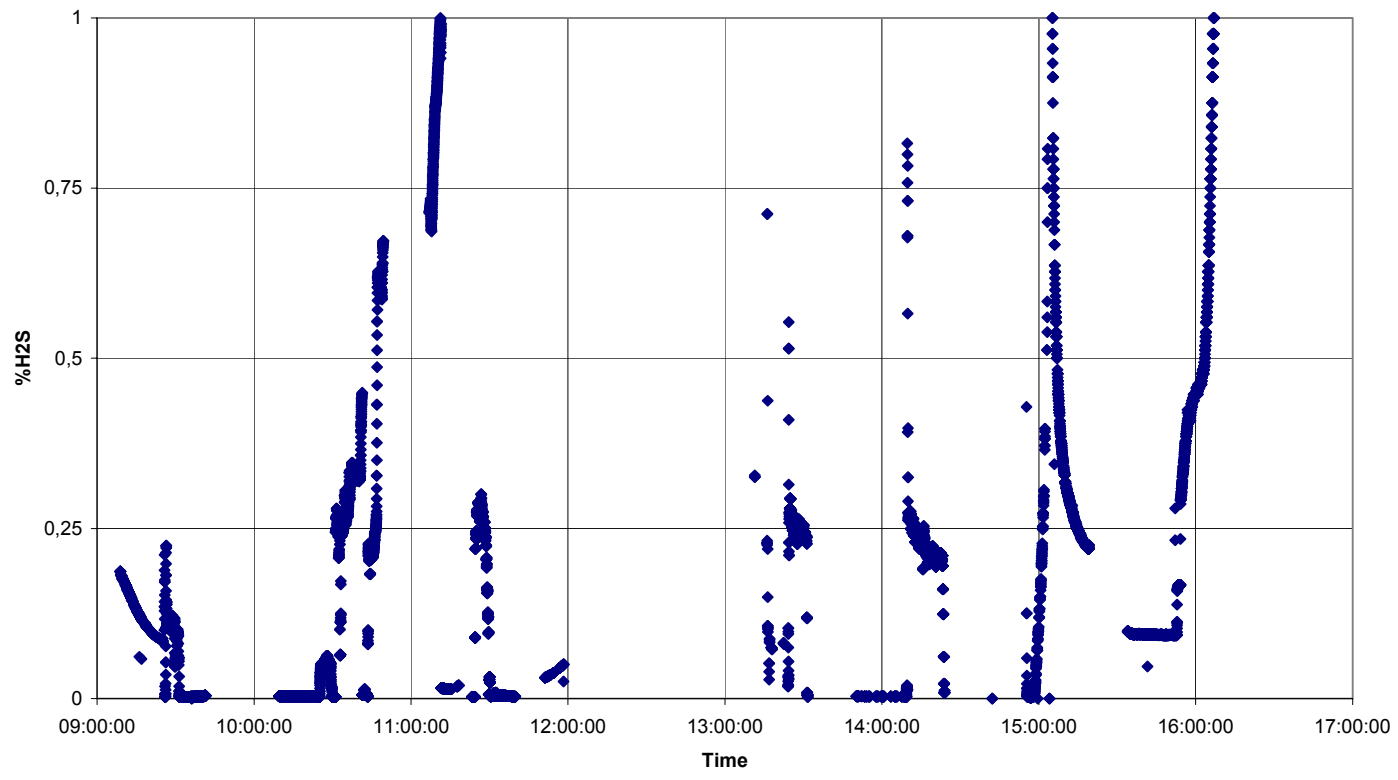


APPENDIX 2

PAGE 15

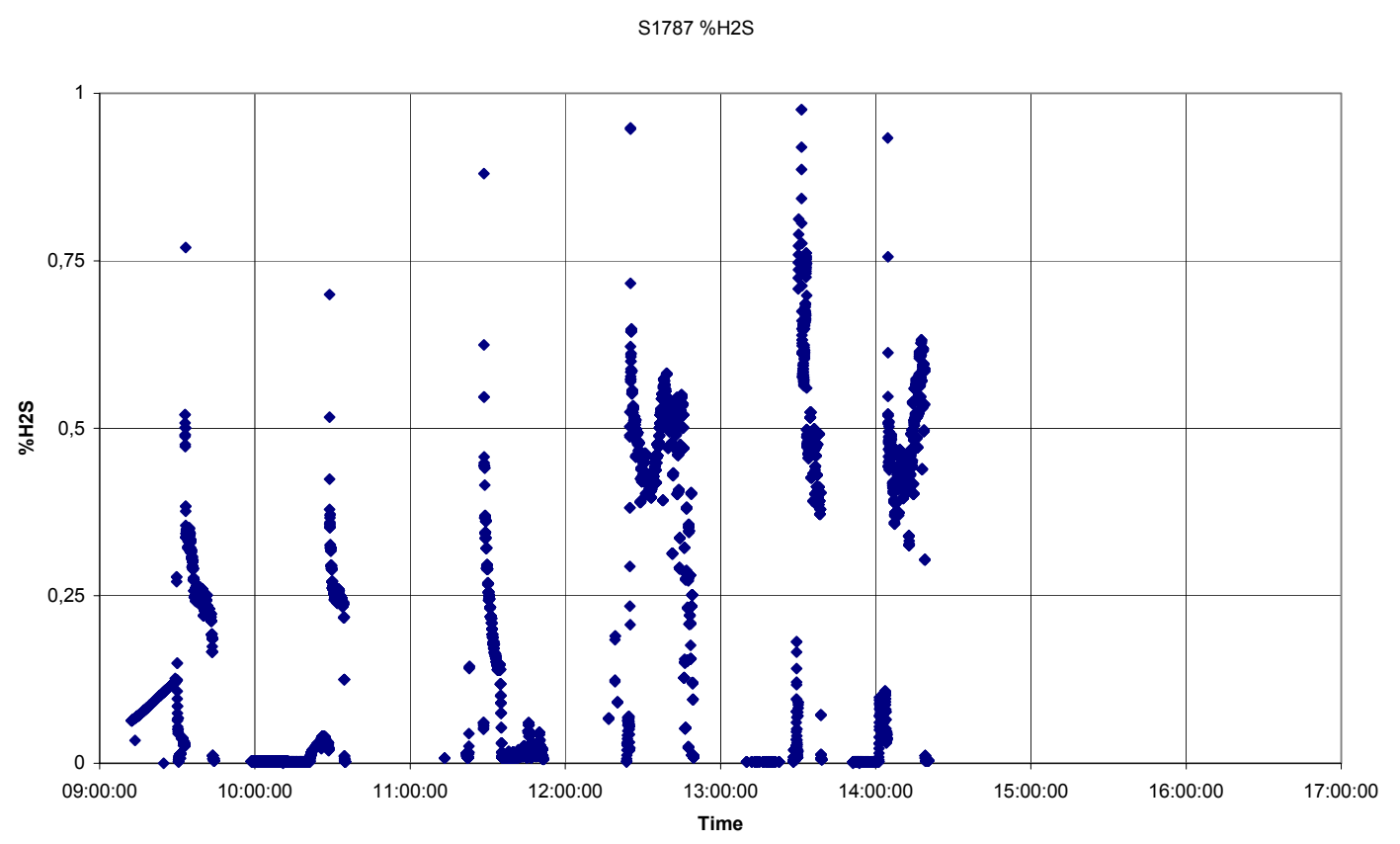


APPENDIX 2

PAGE 16

COS gas analysis

S1783 ppm Cos

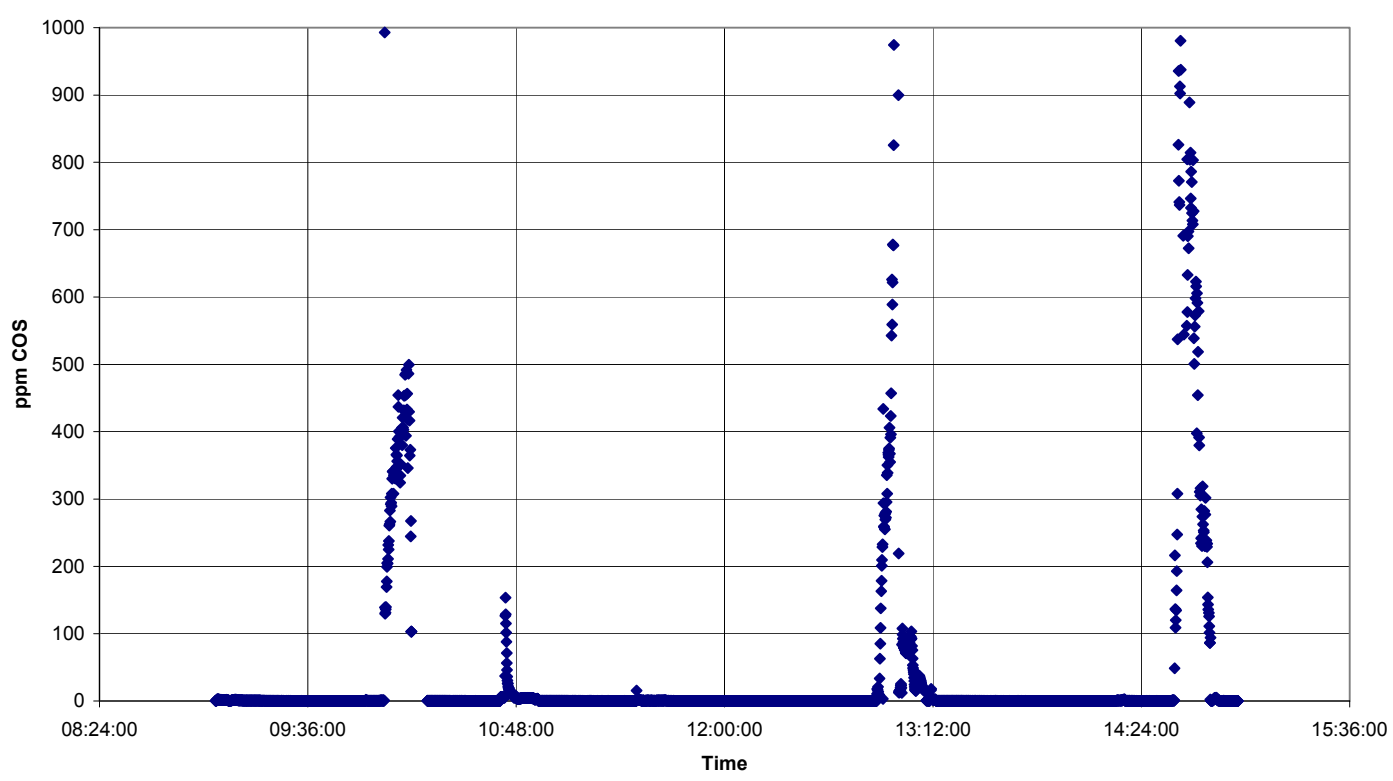

S1784 ppm COS

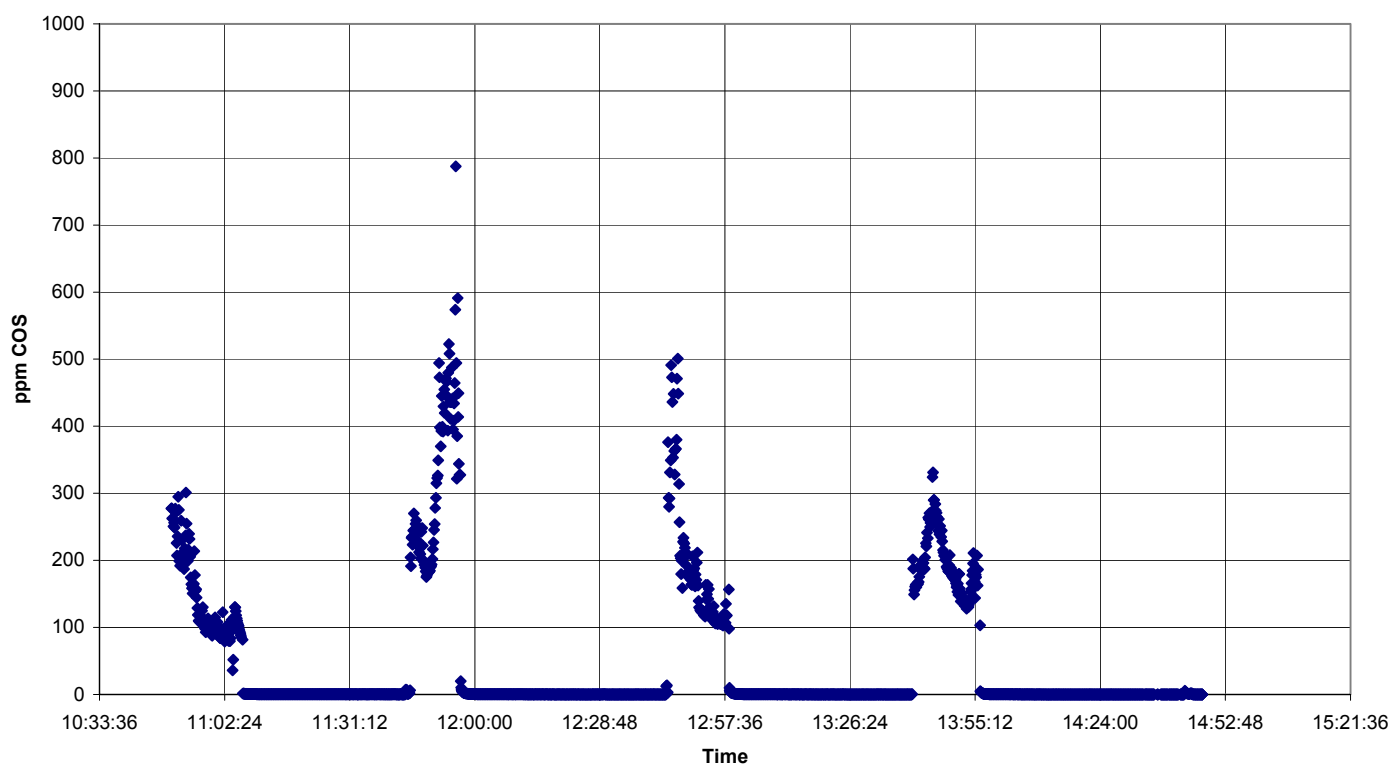


APPENDIX 2

PAGE 17

S1785 ppm COS

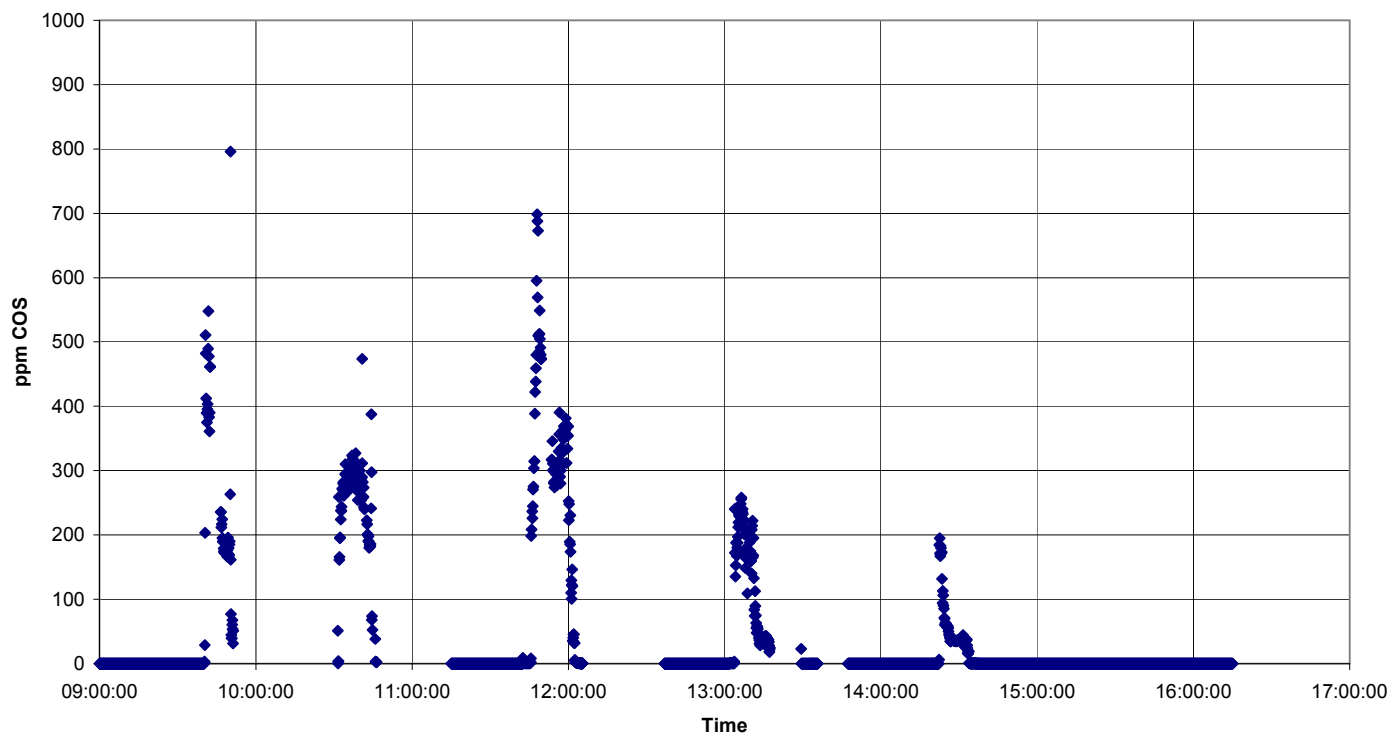

S1786 ppm COS

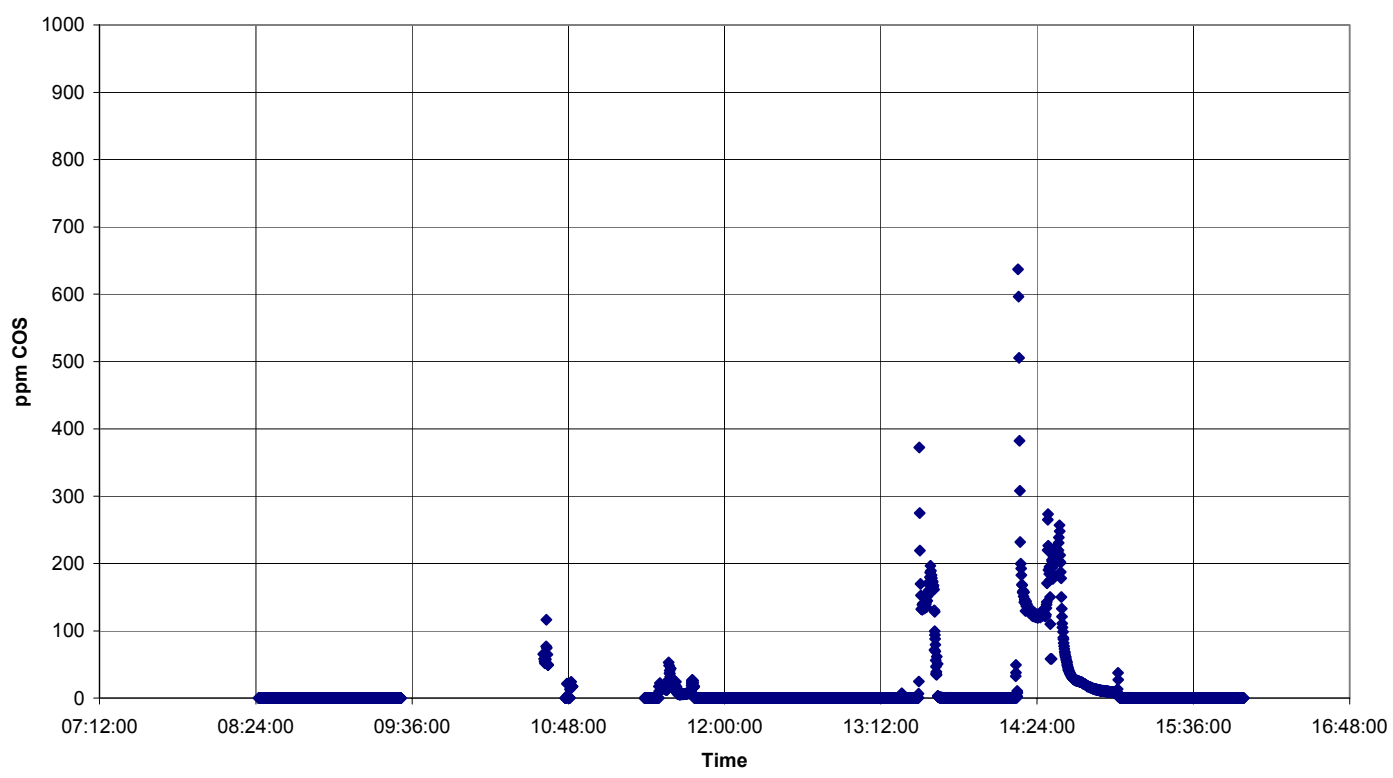


APPENDIX 2

PAGE 18

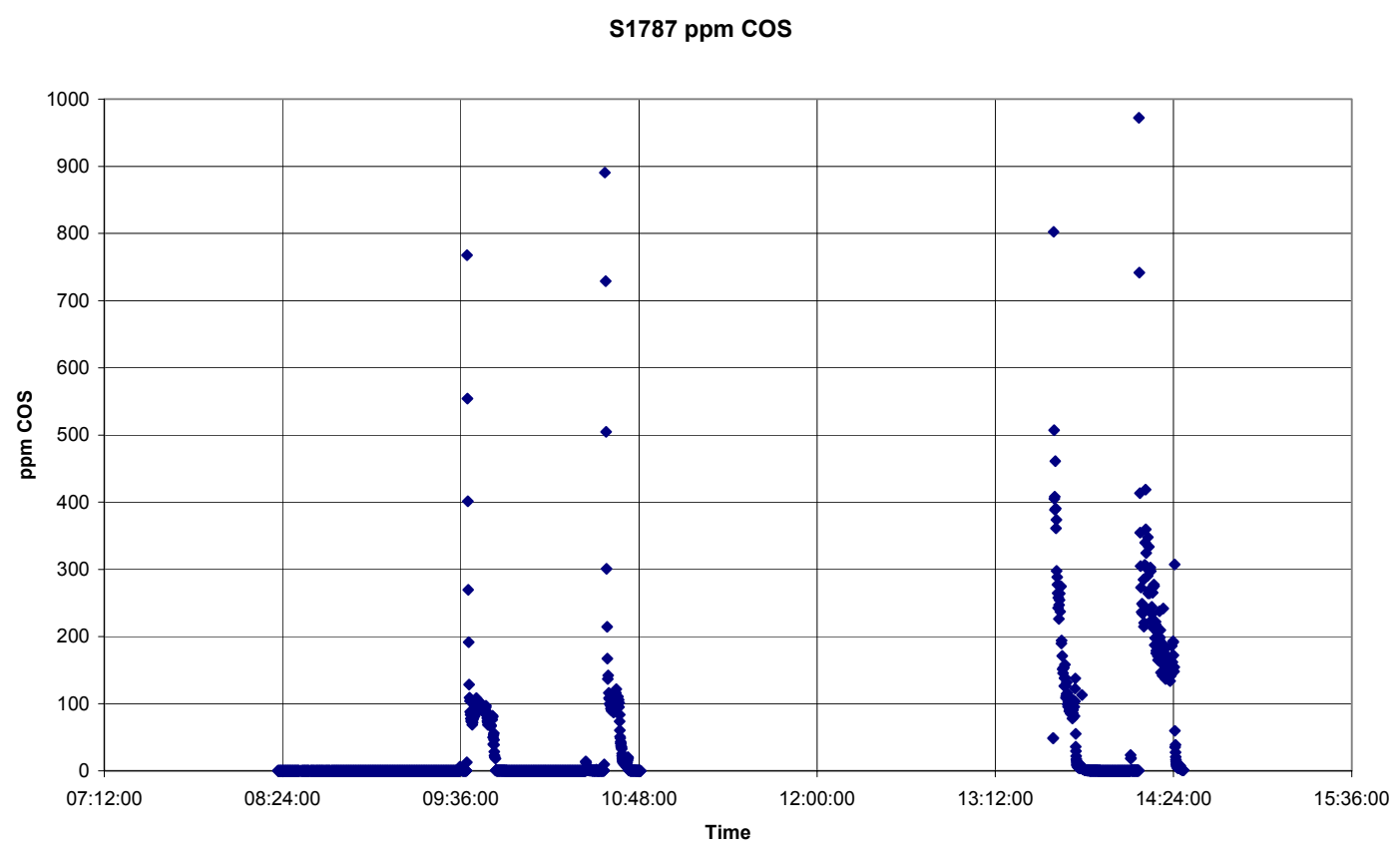


$\mathrm{O}_{2}$ gas analysis

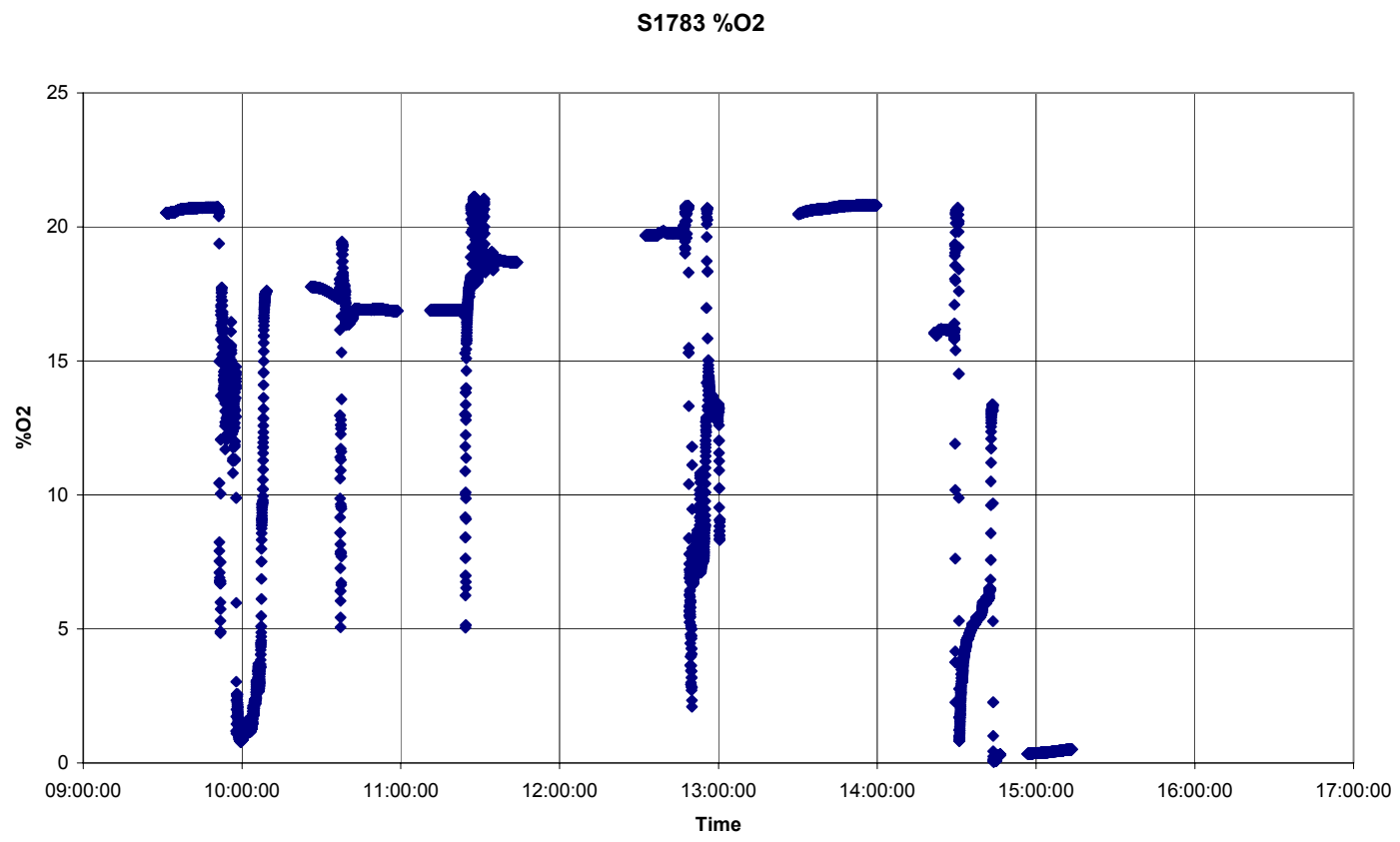

$\mathrm{S} 1784 \% \mathrm{O} 2$

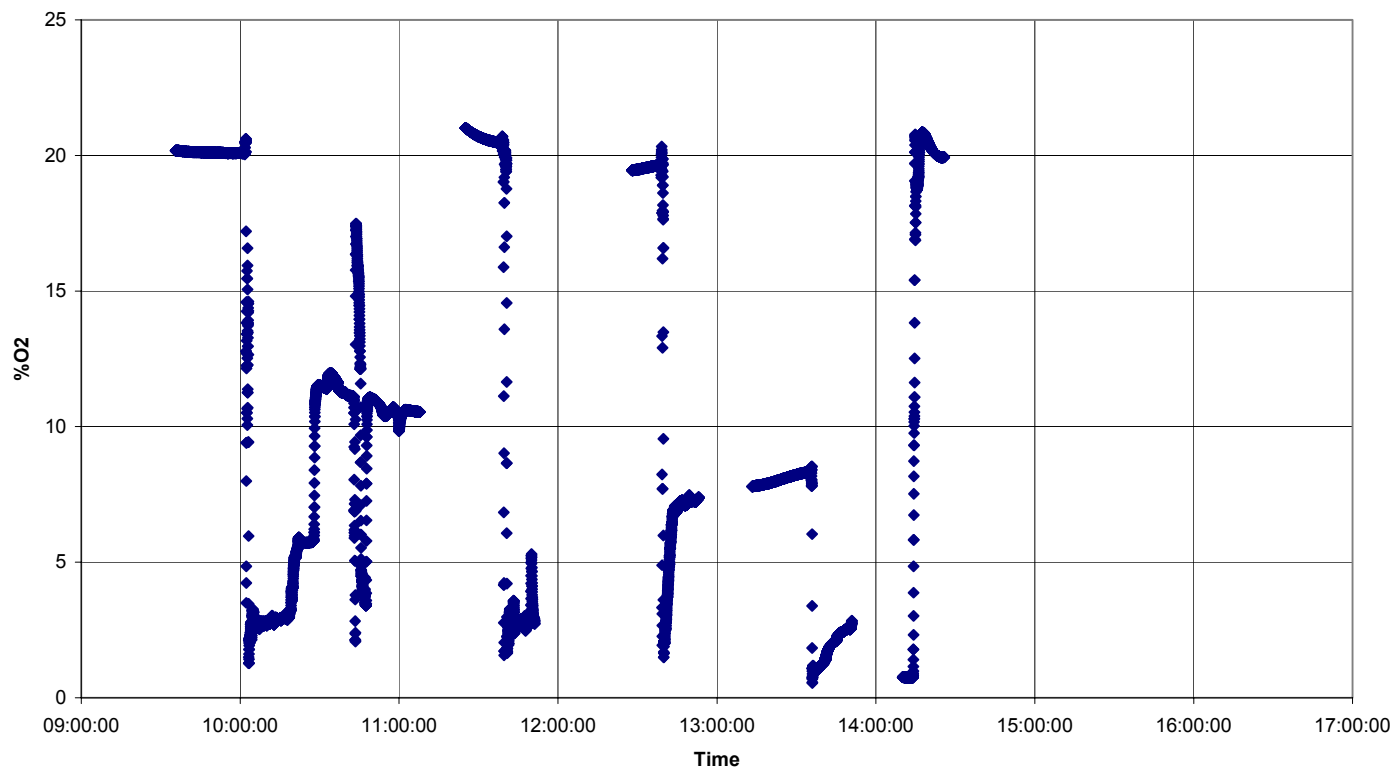


APPENDIX 2

PAGE 20

S1785\%O2

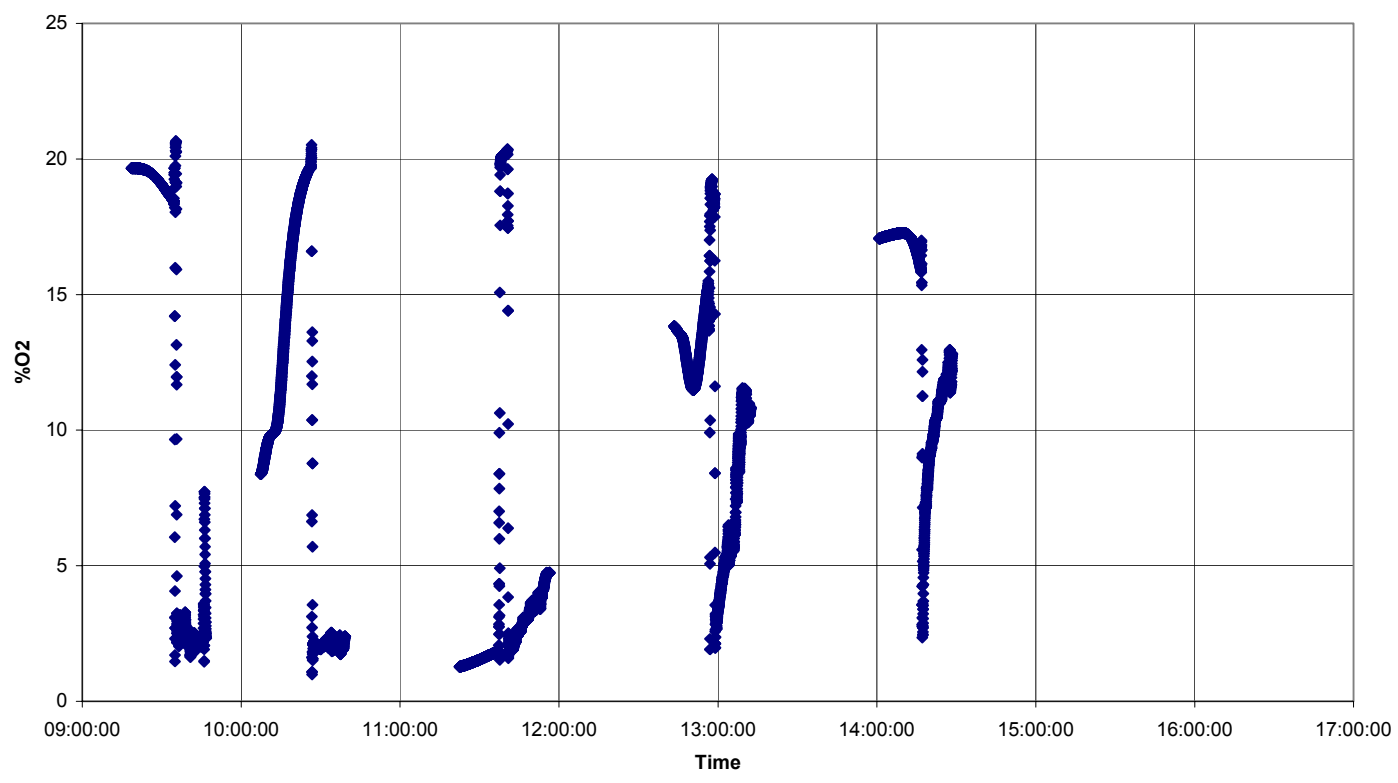

S1786 \%O2

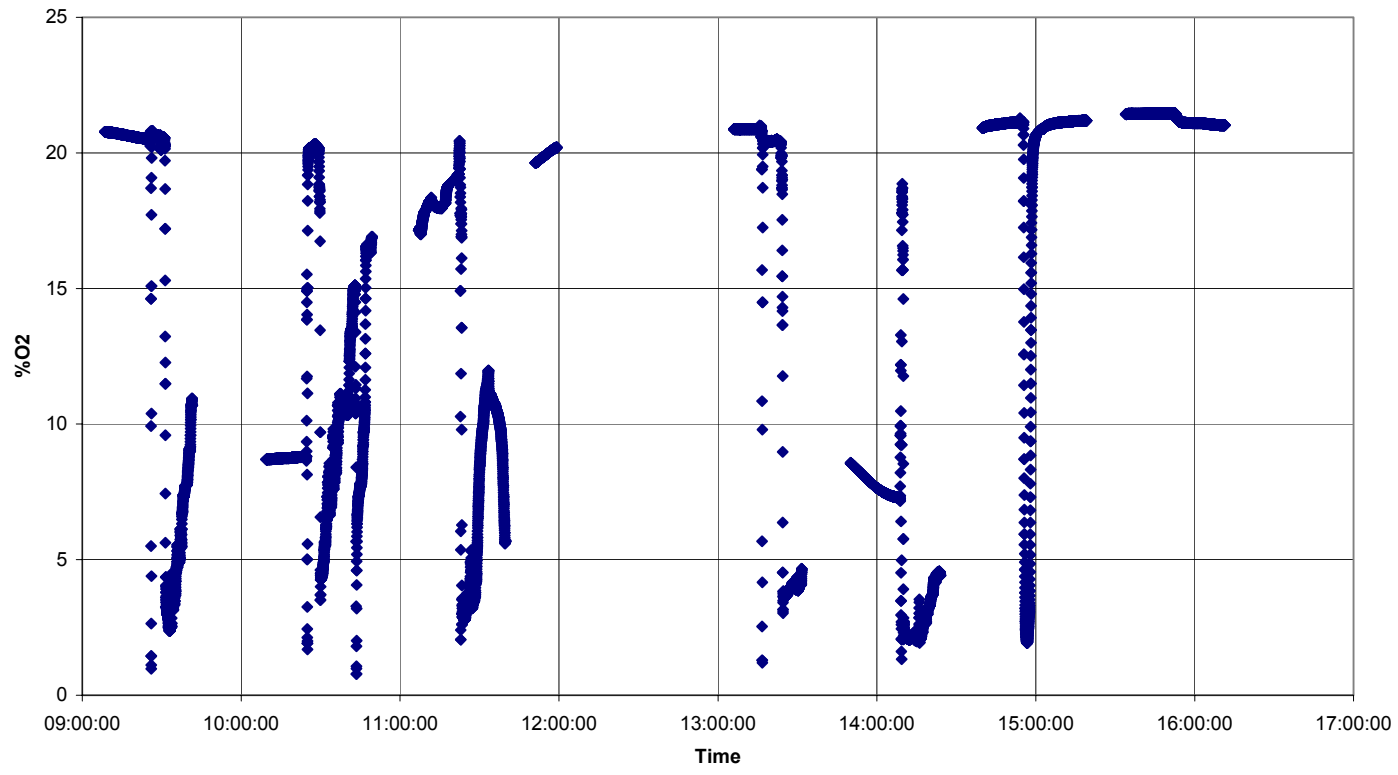


APPENDIX 2

PAGE 21

S1787 \%O2

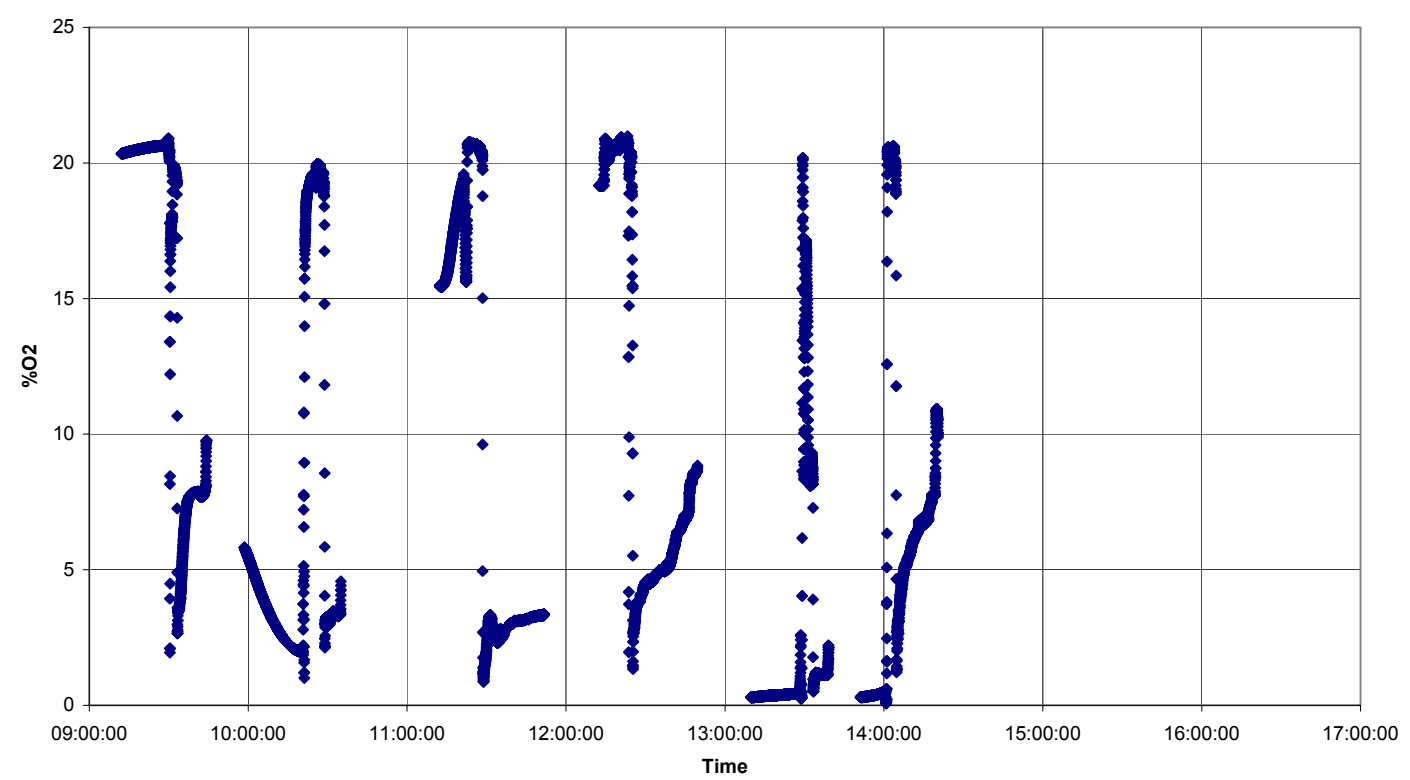


Metal and slag analysis

DOE03QUAT_RPT04DRAFT.DOC

APPENDIX 3

PAGE 1

\begin{tabular}{|c|c|c|c|c|c|c|c|c|c|c|c|c|c|}
\hline Metal & & C & $\mathrm{Si}$ & $\mathrm{Mn}$ & $P$ & S & $\mathrm{Cr}$ & $\mathrm{Ni}$ & $\mathrm{Cu}$ & $\mathrm{V}$ & $\mathrm{Al}$ & Mo & $\mathrm{Ti}$ \\
\hline S1783 & 1 & 3,99 & 0,38 & 0,14 & 0,05 & 0,033 & 0,046 & 0,039 & 0,003 & 0,06 & 0,002 & 0,004 & 0,031 \\
\hline & 3 & 2,89 & & & & 0,028 & & & & & & & \\
\hline & 4 & 1,53 & & & & 0,032 & & & & & & & \\
\hline & 5 & 2,45 & & & & 0,09 & & & & & & & \\
\hline & 6 & 2,31 & & & & 0,039 & & & & & & & \\
\hline & 7 & 1,5 & & & & 0,06 & & & & & & & \\
\hline & 8 & 2,61 & 0 & 0,12 & 0,055 & 0,078 & 0,048 & 0,04 & 0,009 & 0,071 & 0,009 & 0,004 & 0 \\
\hline & 10 & 2,31 & & & & 0,022 & & & & & & & \\
\hline & 11 & 1,58 & & & & 0,059 & & & & & & & \\
\hline & 12 & 1,9 & & & & 0,065 & & & & & & & \\
\hline & 13 & 2,16 & & & & 0,065 & & & & & & & \\
\hline & 14 & 2,97 & & & & 0,043 & & & & & & & \\
\hline & 15 & 1,67 & & & & 0,085 & & & & & & & \\
\hline & 16 & 2,57 & 0 & 0,12 & 0,055 & 0,09 & 0,05 & 0,042 & 0,023 & 0,065 & 0,004 & 0,003 & 0 \\
\hline & 17 & 1,54 & & & & 0,094 & & & & & & & \\
\hline & 18 & 2,35 & & & & 0,09 & & & & & & & \\
\hline & 19 & 2,8 & 0 & 0,12 & 0,054 & 0,055 & 0,05 & 0,042 & 0,03 & 0,062 & 0,007 & 0,003 & 0 \\
\hline & 20 & 2,26 & & & & 0,042 & & & & & & & \\
\hline & 21 & 3,02 & & & & 0,056 & & & & & & & \\
\hline & 22 & 3,46 & 0 & 0,13 & 0,052 & 0,034 & 0,05 & 0,042 & 0,035 & 0,063 & 0,01 & 0,004 & 0 \\
\hline & 23 & 0,99 & 0 & 0,09 & 0,042 & 0,15 & 0,069 & 0,08 & 0,035 & 0,013 & 0,055 & 0,012 & 0 \\
\hline
\end{tabular}

\begin{tabular}{|l|l|l|l|l|l|l|l|l|l|l|l|l|l|l|}
\hline Slag & & $\mathrm{Fe}$ & $\mathrm{CaO}$ & $\mathrm{SiO} 2$ & $\mathrm{MnO}$ & $\mathrm{P} 2 \mathrm{O} 5$ & $\mathrm{~S}$ & $\mathrm{Al} 2 \mathrm{O} 3$ & $\mathrm{MgO}$ & $\mathrm{Na} 2 \mathrm{O}$ & $\mathrm{K} 2 \mathrm{O}$ & $\mathrm{V} 2 \mathrm{O} 5$ & $\mathrm{TiO} 2$ & $\mathrm{Cr} 2 \mathrm{O} 3$ \\
\hline S1783 & 8 & 1,38 & 45,97 & 13,51 & 0,56 & 0,04 & 0,94 & 30,91 & 9,99 & 0,03 & 0,03 & 0,34 & 0,73 & 0,03 \\
\hline & 14 & 13,74 & 39,89 & 7,36 & 0,22 & 0,02 & 1,6 & 38,03 & 12,31 & 0,02 & 0,05 & 0,06 & 0,28 & 0,03 \\
\hline & 16 & 4,29 & 43,65 & 6,05 & 0,49 & 0,03 & 1,04 & 41,5 & 10,32 & 0,02 & 0,02 & 0,25 & 0,22 & 0,03 \\
\hline & 19 & 12,1 & 41,44 & 5,18 & 0,32 & 0,04 & 1,45 & 41,57 & 9,97 & 0,01 & 0,02 & 0,12 & 0,16 & 0,04, \\
\hline & 22 & 7,19 & 43,07 & 3,45 & 0,21 & 0,02 & 1,91 & 43,06 & 10,18 & 0 & 0,01 & 0,05 & 0,1 & 0,03 \\
\hline
\end{tabular}

\begin{tabular}{|l|l|l|l|l|l|l|l|l|l|l|l|l|l|}
\hline Metal & & $\mathrm{C}$ & $\mathrm{Si}$ & $\mathrm{Mn}$ & $\mathrm{P}$ & $\mathrm{S}$ & $\mathrm{Cr}$ & $\mathrm{Ni}$ & $\mathrm{Cu}$ & $\mathrm{V}$ & $\mathrm{Al}$ & $\mathrm{Mo}$ & $\mathrm{Ti}$ \\
\hline S1784 & 1 & 3,87 & 0,3 & 0,07 & 0,05 & 0,044 & 0,045 & 0,042 & 0,002 & 0,061 & 0,027 & 0,003 & 0,012 \\
\hline & 2 & 3,35 & & & & 0,045 & & & & & & & \\
\hline & 3 & 1,68 & & & & 0,046 & & & & & & & \\
\hline & 4 & 3,09 & & & & 0,15 & & & & & & & \\
\hline & 5 & 3,34 & 0 & 0,06 & 0,032 & 0,18 & 0,047 & 0,05 & 0,004 & 0,029 & 0,041 & 0,004 & 0 \\
\hline & 6 & 0,98 & & & & 0,2 & & & & & & & \\
\hline & 7 & 2,06 & & & & 0,29 & & & & & & & \\
\hline & 8 & 2,46 & 0 & 0,07 & 0,041 & 0,31 & 0,051 & 0,051 & 0,003 & 0,016 & 0,017 & 0,003 & 0 \\
\hline & 10 & 1,59 & 0,02 & 0,07 & 0,048 & 0,2 & 0,054 & 0,054 & 0,009 & 0,058 & 0,11 & 0,005 & 0 \\
\hline & 11 & 1,99 & & & & 0,085 & & & & & & & \\
\hline & 12 & 3,77 & 0 & 0,09 & 0,046 & 0,084 & 0,058 & 0,054 & 0,017 & 0,074 & 0,032 & 0,005 & 0 \\
\hline & 13 & 1,74 & 0 & 0,06 & 0,055 & 0,3 & 0,052 & 0,057 & 0,018 & 0,016 & 0,016 & 0,004 & 0 \\
\hline & 14 & 3,45 & 0 & 0,06 & 0,048 & 0,32 & 0,054 & 0,055 & 0,016 & 0,061 & 0,132 & 0,004 & 0 \\
\hline & 15 & 1,3 & 0 & 0,07 & 0,057 & 0,32 & 0,052 & 0,059 & 0,024 & 0,069 & 0,008 & 0,004 & 0 \\
\hline
\end{tabular}

\begin{tabular}{|l|l|l|l|l|l|l|l|l|l|l|l|l|l|l|}
\hline Slag & & $\mathrm{Fe}$ & $\mathrm{CaO}$ & $\mathrm{SiO} 2$ & $\mathrm{MnO}$ & $\mathrm{P} 2 \mathrm{O} 5$ & $\mathrm{~S}$ & $\mathrm{Al} 2 \mathrm{O} 3$ & $\mathrm{MgO}$ & $\mathrm{Na} 2 \mathrm{O}$ & $\mathrm{K} 2 \mathrm{O}$ & $\mathrm{V} 2 \mathrm{O} 5$ & $\mathrm{TiO} 2$ & $\mathrm{Cr} 2 \mathrm{O} 3$ \\
\hline S1784 & 10 & 27,09 & 32,95 & 8,36 & 0,41 & 0,06 & 1,92 & 26,13 & 23,4 & 0,01 & 0,01 & 0,28 & 0,3 & 0,07 \\
\hline & 12 & 24,27 & 34,66 & 4,35 & 0,18 & 0,02 & 3,36 & 36,58 & 17,6 & 0 & 0,01 & 0,07 & 0,15 & 0,05 \\
\hline & 13 & 7,91 & 40,08 & 6,97 & 0,46 & 0,06 & 2,22 & 32,03 & 16,7 & 0 & 0,01 & 0,54 & 0,31 & 0,05 \\
\hline & 14 & 33,28 & 30,41 & 4,65 & 0,28 & 0,04 & 2,53 & 32,42 & 19,45 & 0 & 0,01 & 0,18 & 0,14 & 0,08 \\
\hline & 15 & 4,88 & 28,51 & 4,53 & 0,33 & 0,02 & 2,77 & 34,98 & 27,39 & 0,02 & 0 & 0,26 & 0,19 & 0,15 \\
\hline
\end{tabular}


Metal and slag analysis

DOE03QUAT_RPT04DRAFT.DOC

APPENDIX 3

PAGE 2

\begin{tabular}{|l|l|l|l|l|l|l|l|l|l|l|l|l|l|l|}
\hline Metal & & C & Si & Mn & P & S & Cr & Ni & Cu & V & Al & Mo & Ti \\
\hline S1785 & 1 & 3,94 & & & & 0,053 & & & & & & & \\
\hline & 2 & 1,99 & & & & 0,09 & & & & & & & \\
\hline & 3 & 2,82 & 0 & 0,09 & 0,052 & 0,185 & 0,043 & 0,041 & 0,004 & 0,064 & 0,008 & 0 & 0 \\
\hline & 5 & 1,91 & & & & 0,093 & & & & & & & \\
\hline & 6 & 2,67 & 0 & 0,09 & 0,054 & 0,24 & 0,044 & 0,042 & 0,007 & 0,08 & 0,006 & 0 & 0 \\
\hline & 7 & 1,74 & & & & 0,15 & & & & & & & \\
\hline & 8 & 2,06 & & & & 0,22 & & & & & & & \\
\hline & 9 & 2,75 & 0 & 0,09 & 0,054 & 0,23 & 0,046 & 0,042 & 0,008 & 0,079 & 0 & 0 & 0 \\
\hline & 10 & 1,58 & & & & 0,21 & & & & & & & \\
\hline & 11 & 2,58 & 0 & 0,08 & 0,057 & 0,22 & 0,047 & 0,042 & 0,013 & 0,085 & 0,015 & 0 & 0 \\
\hline & 13 & 1,74 & 0,04 & 0,05 & 0,057 & 0,31 & 0,04 & 0,048 & 0,018 & 0,041 & 0,059 & 0 & 0 \\
\hline
\end{tabular}

\begin{tabular}{|l|l|l|l|l|l|l|l|l|l|l|l|l|l|l|}
\hline Slag & & $\mathrm{Fe}$ & $\mathrm{CaO}$ & $\mathrm{SiO} 2$ & $\mathrm{MnO}$ & $\mathrm{P} 2 \mathrm{O} 5$ & $\mathrm{~S}$ & $\mathrm{Al} 2 \mathrm{O} 3$ & $\mathrm{MgO}$ & $\mathrm{Na} 2 \mathrm{O}$ & $\mathrm{K} 2 \mathrm{O}$ & $\mathrm{V} 2 \mathrm{O} 5$ & $\mathrm{TiO} 2$ & $\mathrm{Cr} 2 \mathrm{O} 3$ \\
\hline S1785 & 3 & 2 & 40,54 & 21,35 & 1,08 & 0,15 & 0,47 & 19,92 & 17,2 & 0,01 & 0,01, & 0,95 & 1,01 & 0,05 \\
\hline & 6 & 1,89 & 36,64 & 21,87 & 0,47 & 0,02 & 0,82 & 19,77 & 24,65 & 0,02 & 0,01 & 0,21 & 0,42 & 0,04 \\
\hline & 9 & 2,18 & 36,8 & 24,34 & 0,31 & 0,01 & 1,37 & 19,05 & 22,43 & 0,02 & 0,01 & 0,08 & 0,24 & 0,03 \\
\hline & 11 & 2,34 & 36,28 & 24,36 & 0,28 & 0,01 & 1,29 & 18,39 & 23,69 & 0,02 & 0,02 & 0,09 & 0,17 & 0,03 \\
\hline
\end{tabular}

\begin{tabular}{|l|l|l|l|l|l|l|l|l|l|l|l|l|l|}
\hline Metal & & $\mathrm{C}$ & $\mathrm{Si}$ & $\mathrm{Mn}$ & $\mathrm{P}$ & $\mathrm{S}$ & $\mathrm{Cr}$ & $\mathrm{Ni}$ & $\mathrm{Cu}$ & $\mathrm{V}$ & $\mathrm{Al}$ & $\mathrm{Mo}$ & $\mathrm{Ti}$ \\
\hline S1786 & 1 & 3,93 & & & & 0,038 & & & & & & & \\
\hline & 2 & 2,04 & & & & 0,046 & & & & & & & \\
\hline & 3 & 2,17 & 0 & 0,08 & 0,056 & 0,077 & 0,04 & 0,039 & 0,003 & 0,054 & 0,018 & 0 & 0 \\
\hline & 4 & 1,52 & 0,02 & 0,09 & 0,063 & 0,063 & 0,043 & 0,038 & 0,006 & 0,055 & 0,008 & 0 & 0 \\
\hline & 1,8 & & & & 0,079 & & & & & & & \\
\hline & 6 & 1,38 & & & & 0,022 & & & & & & & \\
\hline & 7 & 2,09 & 0,6 & 0,1 & 0,063 & 0,043 & 0,039 & 0,041 & 0,01 & 0,057 & 0,03 & 0 & 0 \\
\hline & 8 & 1,56 & 1,24 & 0,09 & 0,066 & 0,0086 & 0,039 & 0,041 & 0,012 & 0,054 & 0,173 & 0 & 0 \\
\hline & 10 & 1,43 & 0,14 & 0,05 & 0,062 & 0,027 & 0,041 & 0,039 & 0,009 & 0,044 & 0,008 & 0 & 0 \\
\hline & 11 & 1,75 & 0,12 & 0,06 & 0,064 & 0,061 & 0,041 & 0,04 & 0,009 & 0,019 & 0,003 & 0 & 0 \\
\hline & 12 & 1,61 & & & & 0,00028 & & & & & & & \\
\hline & 13 & 2,76 & 0,21 & 0,06 & 0,057 & 0,092 & 0,039 & 0,039 & 0,013 & 0,052 & 0,038 & 0 & 0 \\
\hline & 14 & 2,26 & 0,11 & 0,06 & 0,063 & 0,071 & 0,04 & 0,04 & 0,012 & 0,052 & 0,007 & 0 & 0 \\
\hline & 15 & 2,56 & 0,11 & 0,06 & 0,053 & 0,11 & 0,041 & 0,04 & 0,011 & 0,051 & 0,026 & 0 & 0 \\
\hline & 16 & 3,27 & 0,14 & 0,06 & 0,057 & 0,099 & 0,041 & 0,041 & 0,011 & 0,053 & 0,286 & 0 & 0 \\
\hline & 17 & 4,01 & & & & 0,12 & & & & & & & \\
\hline & 18 & 1,77 & 0,13 & 0,05 & 0,046 & 0,018 & 0,026 & 0,024 & 0,008 & 0,041 & 0 & 0 & 0 \\
\hline
\end{tabular}

\begin{tabular}{|l|l|l|l|l|l|l|l|l|l|l|l|l|l|l|}
\hline Slag & & $\mathrm{Fe}$ & $\mathrm{CaO}$ & $\mathrm{SiO} 2$ & $\mathrm{MnO}$ & $\mathrm{P} 2 \mathrm{O} 5$ & $\mathrm{~S}$ & $\mathrm{Al} 2 \mathrm{O} 3$ & $\mathrm{MgO}$ & $\mathrm{Na} 2 \mathrm{O}$ & $\mathrm{K} 2 \mathrm{O}$ & $\mathrm{V} 2 \mathrm{O} 5$ & $\mathrm{TiO} 2$ & $\mathrm{Cr} 2 \mathrm{O} 3$ \\
\hline S1786 & 3 & 7,18 & 42,6 & 31,91 & 1,98 & 0,29 & 0,13 & 4,41 & 8,79 & 0,03 & 0,05 & 1,17 & 1,27 & 0,1 \\
\hline & 4 & 2,31 & 44,26 & 26,61 & 0,55 & 0,04 & 0,23 & 15,08 & 13,76 & 0,01 & 0,04 & 0,29 & 0,55 & 0,05 \\
\hline & 5 & 2,98 & 42,15 & 26,86 & 0,45 & 0,06 & 0,34 & 14,66 & 17,43 & 0 & 0,02 & 0,25 & 0,52 & 0,05 \\
\hline & 8 & 1,07 & 50,18 & 15,64 & 0,2 & 0,01 & 0,59 & 26,46 & 9,02 & 0 & 0,06 & 0,07 & 0,07 & 0,03 \\
\hline & 10 & 3,11 & 34,68 & 33,36 & 0,83 & 0,01 & 0,06 & 15,69 & 16,53 & 0 & 0,03 & 0,27 & 0,1 & 0,05 \\
\hline & 11 & 0,89 & 32,26 & 35,48 & 0,37 & 0,01 & 0,2 & 15,17 & 21,77 & 0,03 & 0,04 & 0,1 & 0,13 & 0,03 \\
\hline & 14 & 1,17 & 37,67 & 24,2 & 0,18 & 0,01 & 0,75 & 20,85 & 20,25 & 0,02 & 0,04 & 0,05 & 0,09 & 0,03 \\
\hline & 16 & 1,19 & 34,57 & 24,67 & 0,17 & 0,01 & 1,27 & 20,98 & 22,08 & 0,03 & 0,04 & 0,04 & 0,07 & 0,03 \\
\hline & 18 & 7,27 & 31,62 & 26,04 & 0,12 & 0,01 & 2,25 & 18,49 & 24,3 & 0,02 & 0,01 & 0,03 & 0,06 & 0,04 \\
\hline
\end{tabular}


Metal and slag analysis

DOE03QUAT_RPT04DRAFT.DOC

APPENDIX 3

PAGE 3

\begin{tabular}{|l|l|l|l|l|l|l|l|l|l|l|l|l|l|}
\hline Metal & & $\mathrm{C}$ & $\mathrm{Si}$ & $\mathrm{Mn}$ & $\mathrm{P}$ & $\mathrm{S}$ & $\mathrm{Cr}$ & $\mathrm{Ni}$ & $\mathrm{Cu}$ & $\mathrm{V}$ & $\mathrm{Al}$ & $\mathrm{Mo}$ & $\mathrm{Ti}$ \\
\hline $\mathrm{S} 1787$ & 1 & 3,99 & & & & 0,05 & & & & & & & \\
\hline & 2 & 2,18 & & & & 0,067 & & & & & & & \\
\hline & 3 & 3,14 & 0,39 & 0,09 & 0,053 & 0,15 & 0,046 & 0,042 & 0,003 & 0,066 & 0,331 & 0 & 0,002 \\
\hline & 4 & 1,06 & 0 & 0,07 & 0,056 & 1,27 & 0,044 & 0,014 & 0,002 & 0,048 & 0,234 & 0 & 0 \\
\hline & 5 & 1,36 & 0 & 0,06 & 0,055 & 1,31 & 0,044 & 0,04 & 0,003 & 0,046 & 0,333 & 0 & 0 \\
\hline & 6 & 1,06 & 0,26 & 0,08 & 0,058 & 0,78 & 0,046 & 0,012 & 0,003 & 0,051 & 0,306 & 0 & 0 \\
\hline & 7 & 1,71 & & & & 0,74 & & & & & & & \\
\hline & 8 & 1,69 & & & & 0,72 & & & & & & & \\
\hline & 9 & 1,52 & & & & 0,79 & & & & & & & \\
\hline & 10 & 2,98 & 0,03 & 0,09 & 0,055 & 0,6 & 0,041 & 0,043 & 0,007 & 1,573 & 0,299 & 0 & 0 \\
\hline & 11 & 1,81 & & & & 0,83 & & & & & & & \\
\hline & 12 & 2,16 & 0 & 0,04 & 0,056 & 0,83 & 0,038 & 0,043 & 0,005 & 0,507 & 0,245 & 0 & 0 \\
\hline & 13 & 1,43 & & & & 0,85 & & & & & & & \\
\hline & 14 & 2,87 & 0 & 0,04 & 0,054 & 0,85 & 0,041 & 0,043 & 0,006 & 0,744 & 0,257 & 0 & 0 \\
\hline
\end{tabular}

\begin{tabular}{|l|l|l|l|l|l|l|l|l|l|l|l|l|l|l|}
\hline Slag & & $\mathrm{Fe}$ & $\mathrm{CaO}$ & $\mathrm{SiO} 2$ & $\mathrm{MnO}$ & $\mathrm{P} 2 \mathrm{O} 5$ & $\mathrm{~S}$ & $\mathrm{Al} 2 \mathrm{O} 3$ & $\mathrm{MgO}$ & $\mathrm{Na} 2 \mathrm{O}$ & $\mathrm{K} 2 \mathrm{O}$ & $\mathrm{V} 2 \mathrm{O} 5$ & $\mathrm{TiO} 2$ & $\mathrm{Cr} 2 \mathrm{O} 3$ \\
\hline S1787 & 3 & 1,85 & 48,71 & 32,69 & 1,24 & 0,12 & 0,24 & 5,92 & 9,46 & 0 & 0,03 & 0,53 & 1,12 & 0,04 \\
\hline & 4 & 3,15 & 40,36 & 27,26 & 0,97 & 0,04 & 1,79 & 11,58 & 16,32 & 0,01 & 0,03 & 0,57 & 0,75 & 0,05 \\
\hline & 5 & 2,72 & 39,14 & 26,66 & 1,06 & 0,05 & 1,97 & 11,48 & 18,51 & 0,01 & 0,02 & 0,63 & 0,74 & 0,06 \\
\hline & 6 & 6,06 & 37,82 & 21,09 & 0,45 & 0,03 & 5,74 & 19,15 & 11,94 & 0 & 0,04 & 0,15 & 0,3 & 0,04 \\
\hline & 10 & 18,65 & 29,67 & 24,32 & 0,38 & 0,02 & 4,81 & 17,52 & 17,24 & 0 & 0,01 & 0,89 & 0,16 & 0,06 \\
\hline & 12 & 3,3 & 39,46 & 20,47 & 0,77 & 0,09 & 2,2 & 14,55 & 12,21 & 0 & 0 & 11,14 & 0,17 & 0,05 \\
\hline & 14 & 4,09 & 36,24 & 26,72 & 0,56 & 0,03 & 2,07 & 16,31 & 13,77 & 0,02 & 0,01 & 6 & 0,21 & 0,06 \\
\hline
\end{tabular}




\section{Carbon balances}

DOE03QUAT_RPT04DRAFT.DOC

APPENDIX 4

PAGE 1

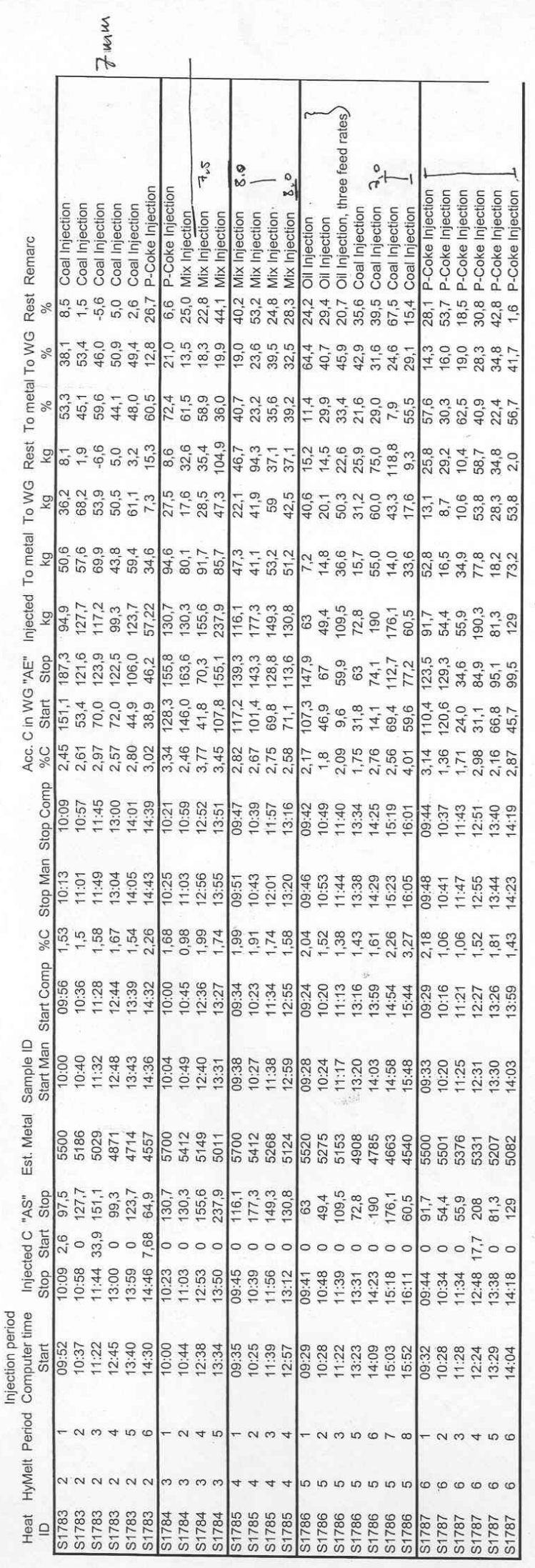




\section{DOE03QUAT RPT04DRAFT.DOC}

APPENDIX 5

PAGE 1

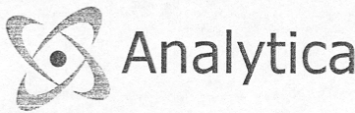

RAPPORT

L0306060

Sidan 1 av 3

MEFOS

L-E From

Box 812

97125 Luleå

\section{Analyspaket: $\quad$ MG2-N}

\begin{tabular}{|ll|l|}
\hline Provnummer: & U10097099-00 & \\
Beteckning 1: & Prov K7 & \\
Beteckning 2: & & \\
\hline
\end{tabular}

\begin{tabular}{|c|c|c|c|c|c|c|c|c|}
\hline Analys & Resultat & Mätosäk. & Enhet & Metod & Analys & Resultat & Mätosäk. Enhet & Metod \\
\hline $\mathrm{SiO}_{2}$ * & 0,882 & & $\%$ & ICP-AES & $\mathrm{S}^{*}$ & 1060 & $\mathrm{mg} / \mathrm{kg}$ & ICP-AES \\
\hline $\mathrm{Al}_{2} \mathrm{O}_{3}$ * & 0,182 & & $\%$ & ICP-AES & $\mathrm{Sc}$ * & $<2$ & $\mathrm{mg} / \mathrm{kg}$ & ICP-AES \\
\hline $\mathrm{CaO} *$ & 0,312 & & $\%$ & ICP-AES & $\mathrm{Sn}$ * & $<30$ & $\mathrm{mg} / \mathrm{kg}$ & ICP-AES \\
\hline $\mathrm{Fe}_{2} \mathrm{O}_{3}$ * & 2,42 & & $\%$ & ICP-AES & $\mathrm{Sr}$ * & 5,77 & $\mathrm{mg} / \mathrm{kg}$ & ICP-AES \\
\hline $\mathrm{K}_{2} \mathrm{O}$ * & 0,235 & & $\%$ & ICP-AES & $\mathrm{V} *$ & 30,9 & $\mathrm{mg} / \mathrm{kg}$ & ICP-AES \\
\hline $\mathrm{MgO}$ * & 0,0700 & & $\%$ & ICP-AES & w * & $<80$ & $\mathrm{mg} / \mathrm{kg}$ & ICP-AES \\
\hline $\mathrm{MnO}$ * & 0,195 & & $\%$ & ICP-AES & $\mathrm{Y} *$ & $<3$ & $\mathrm{mg} / \mathrm{kg}$ & ICP-AES \\
\hline $\mathrm{Na}_{2} \mathrm{O}$ * & 0,118 & & $\%$ & ICP-AES & $\mathrm{Zn}$ * & 585 & $\mathrm{mg} / \mathrm{kg}$ & ICP-AES \\
\hline $\mathrm{P}_{2} \mathrm{O}_{5}$ * & 0,0095 & & $\%$ & ICP-AES & $\mathrm{Zr}$ * & 3,23 & $\mathrm{mg} / \mathrm{kg}$ & ICP-AES \\
\hline $\mathrm{TiO}_{2}$ * & 0,0045 & & $\%$ & ICP-AES & & & & \\
\hline Summa * & 4,4 & & $\%$ & Man.Inm. & & & & \\
\hline As * & $<7$ & & $\mathrm{mg} / \mathrm{kg}$ & ICP-QMS & & & & \\
\hline $\mathrm{Ba}$ * & 151 & & $\mathrm{mg} / \mathrm{kg}$ & ICP-AES & & & & \\
\hline $\mathrm{Be}$ * & $<0,8$ & & $\mathrm{mg} / \mathrm{kg}$ & ICP-AES & & & & \\
\hline $\mathrm{Cd}$ * & $<0,7$ & & $\mathrm{mg} / \mathrm{kg}$ & ICP-QMS & & & & \\
\hline $\mathrm{C}_{0}$ * & 4,85 & & $\mathrm{mg} / \mathrm{kg}$ & ICP-QMS & & & & \\
\hline $\mathrm{Cr}$ * & 62,1 & & $\mathrm{mg} / \mathrm{kg}$ & ICP-AES & & & & \\
\hline $\mathrm{Cu}$ * & 30,4 & & $\mathrm{mg} / \mathrm{kg}$ & ICP-QMS & & & & \\
\hline $\mathrm{Hg}$ * & $<0,5$ & & $\mathrm{mg} / \mathrm{kg}$ & AFS & & & & \\
\hline $\mathrm{La}$ * & $<8$ & & $\mathrm{mg} / \mathrm{kg}$ & ICP-AES & & & & \\
\hline Mo * & 9,70 & & $\mathrm{mg} / \mathrm{kg}$ & ICP-AES & & & & \\
\hline $\mathrm{Nb}$ * & $<8$ & & $\mathrm{mg} / \mathrm{kg}$ & ICP-AES & & & & \\
\hline $\mathrm{Ni}$ * & 60,9 & & $\mathrm{mg} / \mathrm{kg}$ & ICP-AES & & & & \\
\hline $\mathrm{Pb}$ * & 109 & & $\mathrm{mg} / \mathrm{kg}$ & ICP-QMS & & & & \\
\hline
\end{tabular}

Vid analys av As, Cd, Cu, Co, Hg, Ni, Pb, Sb, Se och S gäller: Upplösning har skett enligt ASTM D3683 (modifierad). För övriga grundämnen har upplösning skett enligt AST'M D3682 $\left(\mathrm{LiBO}_{2}\right.$ - smälta) .

Vid a nalys av B har upplösning skett i mikrovå gsugn med HNO3.

Analys har skett enligt EPA -metoder (modifierade) 200.7 (ICP-AES) och 200.8 (ICP-QMS).

Parametrar märkta med * indikerar ej ackrediterade analyser.

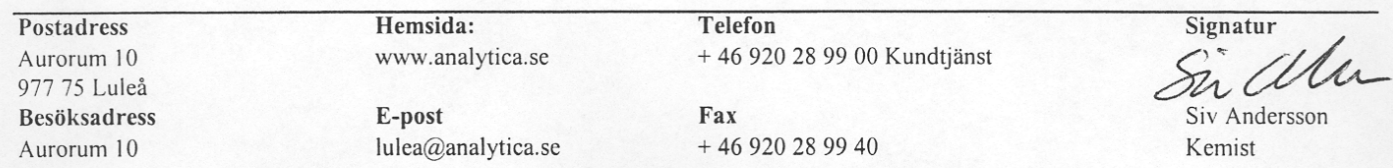




\section{DOE03QUAT RPT04DRAFT.DOC}

APPENDIX 5

PAGE 2

\section{L0306060}

Sidan 2 av 3

MEFOS

L-E From

Box 812

97125 Luleå

Analyspaket:

MG2-N

\begin{tabular}{|c|c|c|c|c|c|c|c|c|}
\hline \multicolumn{2}{|c|}{$\begin{array}{l}\text { Provnummer: } \\
\text { Beteckning 1: } \\
\text { Beteckning 2: }\end{array}$} & \multicolumn{3}{|c|}{$\begin{array}{l}\text { U10097100-00 } \\
\text { Prov K21 }\end{array}$} & \multirow{2}{*}{\begin{tabular}{|l} 
\\
Analys
\end{tabular}} & \multirow[b]{2}{*}{ Resultat } & \multirow[b]{2}{*}{ Mätosäk. Enhet } & \multirow[b]{2}{*}{ Metod } \\
\hline Analys & Resultat & Mätosäk. & Enhet & Metod & & & & \\
\hline $\mathrm{SiO}_{2}$ * & 21,4 & & $\%$ & ICP-AES & $S^{*}$ & 545 & $\mathrm{mg} / \mathrm{kg}$ & ICP-AES \\
\hline $\mathrm{Al}_{2} \mathrm{O}_{3}$ * & 1,76 & & $\%$ & ICP-AES & $\mathrm{Sc}$ * & $<10$ & $\mathrm{mg} / \mathrm{kg}$ & ICP-AES \\
\hline $\mathrm{CaO}$ * & 1,09 & & $\%$ & ICP-AES & $\mathrm{Sn}$ * & $<200$ & $\mathrm{mg} / \mathrm{kg}$ & ICP-AES \\
\hline $\mathrm{Fe}_{2} \mathrm{O}_{3}$ * & 0,980 & & $\%$ & ICP-AES & $\mathrm{Sr}$ * & 63,4 & $\mathrm{mg} / \mathrm{kg}$ & ICP-AES \\
\hline $\mathrm{K}_{2} \mathrm{O}$ * & 0,879 & & $\%$ & ICP-AES & $\mathrm{V} *$ & 20,5 & $\mathrm{mg} / \mathrm{kg}$ & ICP-AES \\
\hline $\mathrm{MgO}$ * & 0,348 & & $\%$ & ICP-AES & $\mathrm{W}$ * & $<500$ & $\mathrm{mg} / \mathrm{kg}$ & ICP-AES \\
\hline $\mathrm{MnO}$ * & $<0,03$ & & $\%$ & ICP-AES & $\mathrm{Y} *$ & $<20$ & $\mathrm{mg} / \mathrm{kg}$ & ICP-AES \\
\hline $\mathrm{Na}_{2} \mathrm{O}$ * & 1,16 & & $\%$ & ICP-AES & $\mathrm{Zn}$ * & 463 & $\mathrm{mg} / \mathrm{kg}$ & ICP-AES \\
\hline $\mathrm{P}_{2} \mathrm{O}_{5}$ * & 0,0319 & & $\%$ & ICP-AES & $\mathrm{Zr}$ * & 44,0 & $\mathrm{mg} / \mathrm{kg}$ & ICP-AES \\
\hline $\mathrm{TiO}_{2}$ * & 0,0462 & & $\%$ & ICP-AES & & & & \\
\hline Summa * & 27,7 & & $\%$ & Man.Inm. & & & & \\
\hline As * & $<7$ & & $\mathrm{mg} / \mathrm{kg}$ & ICP-QMS & & & & \\
\hline $\mathrm{Ba}$ * & 2740 & & $\mathrm{mg} / \mathrm{kg}$ & ICP-AES & & & & \\
\hline $\mathrm{Be}$ * & $<5$ & & $\mathrm{mg} / \mathrm{kg}$ & ICP-AES & & & & \\
\hline$C d^{*}$ & $<0,7$ & & $\mathrm{mg} / \mathrm{kg}$ & ICP-QMS & & & & \\
\hline $\mathrm{Co}^{*}$ & 0,929 & & $\mathrm{mg} / \mathrm{kg}$ & ICP-QMS & & & & \\
\hline $\mathrm{Cr}^{*}$ & $<100$ & & $\mathrm{mg} / \mathrm{kg}$ & ICP-AES & & & & \\
\hline $\mathrm{Cu}$ * & $<7$ & & $\mathrm{mg} / \mathrm{kg}$ & ICP-QMS & & & & \\
\hline $\mathrm{Hg}$ * & $<0,6$ & & $\mathrm{mg} / \mathrm{kg}$ & AFS & & & & \\
\hline $\mathrm{La} *$ & $<50$ & & $\mathrm{mg} / \mathrm{kg}$ & ICP-AES & & & & \\
\hline Mo * & $<50$ & & $\mathrm{mg} / \mathrm{kg}$ & ICP-AES & & & & \\
\hline $\mathrm{Nb}$ * & $<50$ & & $\mathrm{mg} / \mathrm{kg}$ & ICP-AES & & & & \\
\hline $\mathrm{Ni}$ * & $<6$ & & $\mathrm{mg} / \mathrm{kg}$ & ICP-QMS & & & & \\
\hline $\mathrm{Pb}$ * & 35,0 & & $\mathrm{mg} / \mathrm{kg}$ & ICP-QMS & & & & \\
\hline
\end{tabular}

Vid analys av $\mathrm{As}, \mathrm{Cd}, \mathrm{Cu}, \mathrm{Co}, \mathrm{Hg}, \mathrm{Ni}, \mathrm{Pb}, \mathrm{Sb}$, Se och $\mathrm{S}$ gäller: Upplösning har skett enligt ASTM D3683 (modifierad). För övriga grundämnen har upplösning skett enligt ASTM D3682 $\left(\mathrm{LiBO}_{2}-\right.$ smälta) .

Vid a nalys av B har upplösning skett i mikrovågsugn med HNO3.

Analys har skett enligt EPA -metoder (modifierade) 200.7 (ICP-AES ) och 200.8 (ICP-QMS).

Parametrar märk ta med * indikerar ej ackrediterade analyser.

\begin{tabular}{llll}
\hline Postadress & Hemsida: & Telefon & Signatur \\
$\begin{array}{l}\text { Aurorum 10 } \\
97775 \text { Luleå }\end{array}$ & www.analytica.se & +46920289900 Kundtjänst & SUA \\
Besöksadress & E-post & Fax & Siv Andersson \\
Aurorum 10 & lulea@analytica.se & +46920289940 & Kemist
\end{tabular}




\section{DOE03QUAT_RPT04DRAFT.DOC}

APPENDIX 5

PAGE 3

\section{L0306060}

Analytica

RAPPORT

Sidan 3 av 3

MEFOS

L-E From

Box 812

97125 Luleå

2003-06-26

2003-07-14

2003-07-14

Er Order Id:

Registrerad:

Utfärdad:

MG2-N

Analyspaket:

Provnummer:

Beteckning 1:

U10097101-00

Beteckning 2:

Prov K25

Analys Resultat Mätosäk. Enhet

$\mathrm{SiO}_{2}$ * $\quad 0,849$

$\mathrm{Al}_{2} \mathrm{O}_{3}$ * $\quad 0,308$

$\mathrm{CaO}$ * $\quad 0,129$

$\mathrm{Fe}_{2} \mathrm{O}_{3}$ * $\quad 0,987$

$\mathrm{K}_{2} \mathrm{O}$ * $\quad 0,0974$

$\mathrm{MgO}$ * $\quad 0,0398$

$\mathrm{MnO}$ * $\quad 0,0167$

$\mathrm{Na}_{2} \mathrm{O} * \quad 0,0926$

$\mathrm{P}_{2} \mathrm{O}_{5}$ * $\quad 0,0081$

$\mathrm{TiO}_{2}$ * $\quad 0,0090$

Summa * 2,5

As * $\quad 5,46$

$\mathrm{Ba}$ * $\quad 105$

$\mathrm{Be}^{*}<0,6$

$\mathrm{Cd}^{*} \quad<0,4$

$\mathrm{C}_{0}$ * $\quad 2,63$

$\mathrm{Cr}$ * $\quad 12,7$

$\mathrm{Cu}$ * $\quad 4,72$

$\mathrm{Hg}$ * $\quad<0,3$

$\mathrm{La} * \quad 7,51$

$\mathrm{Mo}^{*}<6$

$\mathrm{Nb}$ * $\quad<6$

$\mathrm{Ni}$ * $\quad 43,2$

$\mathrm{Pb}$ * $\quad 8,10$

ICP-AES

ICP-AES

ICP-AES

ICP-AES

ICP-AES

ICP-AES

ICP-AES

ICP-AES

ICP-AES

ICP-AES

Man.Inm.

ICP-QMS

ICP-AES

ICP-AES

ICP-QMS

ICP-QMS

ICP-AES

ICP-QMS

AFS

ICP-AES

ICP-AES

ICP-AES

ICP-AES

ICP-QMS

\begin{tabular}{|c|c|c|c|}
\hline Analys & Resultat & Mätosäk. Enhet & Metod \\
\hline $\mathrm{S}^{*}$ & 4020 & $\mathrm{mg} / \mathrm{kg}$ & ICP-AES \\
\hline $\mathrm{Sc}$ * & $<1$ & $\mathrm{mg} / \mathrm{kg}$ & ICP-AES \\
\hline $\mathrm{Sn}$ * & $<20$ & $\mathrm{mg} / \mathrm{kg}$ & ICP-AES \\
\hline $\mathrm{Sr}$ * & 8,03 & $\mathrm{mg} / \mathrm{kg}$ & ICP-AES \\
\hline $\mathrm{V} *$ & 283 & $\mathrm{mg} / \mathrm{kg}$ & ICP-AES \\
\hline $\mathrm{W}$ * & $<60$ & $\mathrm{mg} / \mathrm{kg}$ & ICP-AES \\
\hline$Y^{*}$ & $<2$ & $\mathrm{mg} / \mathrm{kg}$ & ICP-AES \\
\hline $\mathrm{Zn}$ * & 44,2 & $\mathrm{mg} / \mathrm{kg}$ & ICP-AES \\
\hline $\mathrm{Zr}$ * & 2,54 & $\mathrm{mg} / \mathrm{kg}$ & ICP-AES \\
\hline
\end{tabular}

Vid analys av $\mathrm{As}, \mathrm{Cd}, \mathrm{Cu}, \mathrm{Co}, \mathrm{Hg}, \mathrm{Ni}, \mathrm{Pb}$, Sb, Se och $\mathrm{S}$ gäller: Upplösning har skett enligt ASTM D3683 (modifierad). För övriga grundämnen har upplösning skett en ligt ASTiM D3682 $\left(\mathrm{LiBO}_{2}\right.$ - smälta) .

Vid a nalys av B har upplösning skett i mikrovågsugn med HNO3.

Analys har skett enligt EPA -meto der (modifierade) 200.7 (ICP-AES) och 200.8 (ICP-QMS).

Parametrar märk ta med * indikerar ej ackrediterade analyser.

\begin{tabular}{llll}
\hline Postadress & Hemsida: & Telefon & Signatur \\
$\begin{array}{l}\text { Aurorum 10 } \\
97775 \text { Luleå }\end{array}$ & www.analytica.se & +46920289900 Kundtjänst & \\
Besöksadress & E-post & Fax & Siv Andersson \\
Aurorum 10 & lulea@analytica.se & +46920289940 & Kemist
\end{tabular}


Dust load in combusted gas

DOE03QUAT_RPT04DRAFT.DOC

APPENDIX 6

PAGE 1

DUST SAMPLES-Preliminary

Sample
No
1 Before wet venturie, off gas
2 Before wet venturie, off gas
3 Before wet venturie, off gas
4 Before wet venturie, off gas
5 Before wet venturie, off gas
6 Before wet venturie, off gas
7 Before wet venturie, off gas
8 Before wet venturie, off gas
9 Before wet venturie, off gas
10 Before wet venturie, off gas
11 Before wet venturie, off gas
12 Before wet venturie, off gas
13 Before wet venturie, off gas
14 Before wet venturie, off gas
15 Before wet venturie, off gas
16 Before wet venturie, off gas
17 Before wet venturie, off gas
18 Before wet venturie, off gas
19 Before wet venturie, off gas
20 Before wet venturie, off gas
21 Before wet venturie, off gas
22 Before wet venturie, off gas
23 Before wet venturie, off gas
24 Before wet venturie, off gas
25 Before wet venturie, off gas
26 Before wet venturie, off gas
27 Before wet venturie, off gas
28 Before wet venturie, off gas
29 Before wet venturie, off gas
30 Before wet venturie, off gas

2003-06-18

\begin{tabular}{|c|c|c|c|c|c|}
\hline Date & $\begin{array}{l}\text { Starttime } \\
\text { hhmm }\end{array}$ & $\begin{array}{l}\text { Stoptime } \\
\text { hhmm }\end{array}$ & $\begin{array}{l}\text { Meas.Time } \\
\text { min }\end{array}$ & $\begin{array}{l}\text { Dust content } \\
\text { g/m } 3 n \text { dry gas }\end{array}$ & $\begin{array}{c}\text { Moisture } \\
\%\end{array}$ \\
\hline 2003-06-05 & 11,41 & 11,55 & 14,00 & 9,80 & 2,04 \\
\hline $2003-06-05$ & 12,38 & 12,47 & 9,00 & 2,40 & 3,40 \\
\hline 2003-06-05 & 14,03 & 14,29 & 26,00 & 3,60 & 1,22 \\
\hline 2003-06-05 & 14,53 & 15,10 & 17,00 & 2,90 & 2,82 \\
\hline 2003-06-06 & 9,56 & 10,16 & 20,00 & 3,60 & 2,59 \\
\hline 2003-06-06 & 10,41 & 11,01 & 20,00 & 4,60 & 3,62 \\
\hline 2003-06-06 & 11,23 & 11,49 & 26,00 & 1,70 & 1,99 \\
\hline 2003-06-06 & 12,49 & 13,01 & 12,00 & 1,90 & 2,65 \\
\hline 2003-06-06 & 13,51 & 14,01 & 10,00 & 2,20 & 6,09 \\
\hline 2003-06-06 & 14,34 & 14,48 & 14,00 & 3,20 & 0,94 \\
\hline 2003-06-10 & 10,06 & 10,23 & 17,00 & 9,90 & 1,02 \\
\hline 2003-06-10 & 10,48 & 11,03 & 15,00 & 8,60 & 2,27 \\
\hline $2003-06-10$ & 11,42 & 11,51 & 9,00 & 11,70 & 2,44 \\
\hline $2003-06-10$ & 12,38 & 12,53 & 15,00 & 13,00 & 2,47 \\
\hline $2003-06-10$ & 13,35 & 13,51 & 16,00 & 21,20 & 1,35 \\
\hline 2003-06-11 & 9,40 & 9,50 & 10,00 & 13,30 & 2,72 \\
\hline 2003-06-11 & 10,30 & 10,43 & 13,00 & 10,70 & 2,59 \\
\hline 2003-06-11 & 11,40 & 11,56 & 16,00 & 7,20 & 2,49 \\
\hline 2003-06-11 & 12,59 & 13,12 & 13,00 & 7,00 & 2,91 \\
\hline 2003-06-11 & 14,17 & 14,29 & 12,00 & 12,80 & 2,38 \\
\hline 2003-06-12 & 11,23 & 11,39 & 16,00 & 11,10 & 3,38 \\
\hline 2003-06-12 & 13,28 & 13,36 & 8,00 & 2,80 & 3,50 \\
\hline 2003-06-12 & 14,14 & 14,29 & 15,00 & 11,60 & 2,5 \\
\hline $2003-06-12$ & 15,56 & 16,16 & 20,00 & 14,60 & 1,87 \\
\hline $2003-06-13$ & 9,26 & 9,48 & 22,00 & 6,30 & 3,34 \\
\hline 2003-06-13 & 10,33 & 10,39 & 6,00 & 8,10 & 4,81 \\
\hline $2003-06-13$ & 11,33 & 11,56 & 23,00 & 0,70 & 1,56 \\
\hline $2003-06-13$ & 12,29 & 12,53 & 24,00 & 9,20 & 2,72 \\
\hline $2003-06-13$ & 13,34 & 13,44 & 10,00 & 10,80 & 3,17 \\
\hline $2003-06-13$ & 14,09 & 14,23 & 14,00 & 12,40 & 1,67 \\
\hline
\end{tabular}


APPENDIX 7

PAGE 1

5. Analytica

L0306059

Sidan 1 av 3

Er Order Id:

Registrerad:

Analyserad:

2003-06-26

MEFOS

Utfärdad:

2003-07-14

2003-07-25 Box 812

97125 Luleå

Analyspaket:

MG2-N

Provnummer: U10097096-0

Beteckning 1: $\quad$ Prov 7

Beteckning 2:

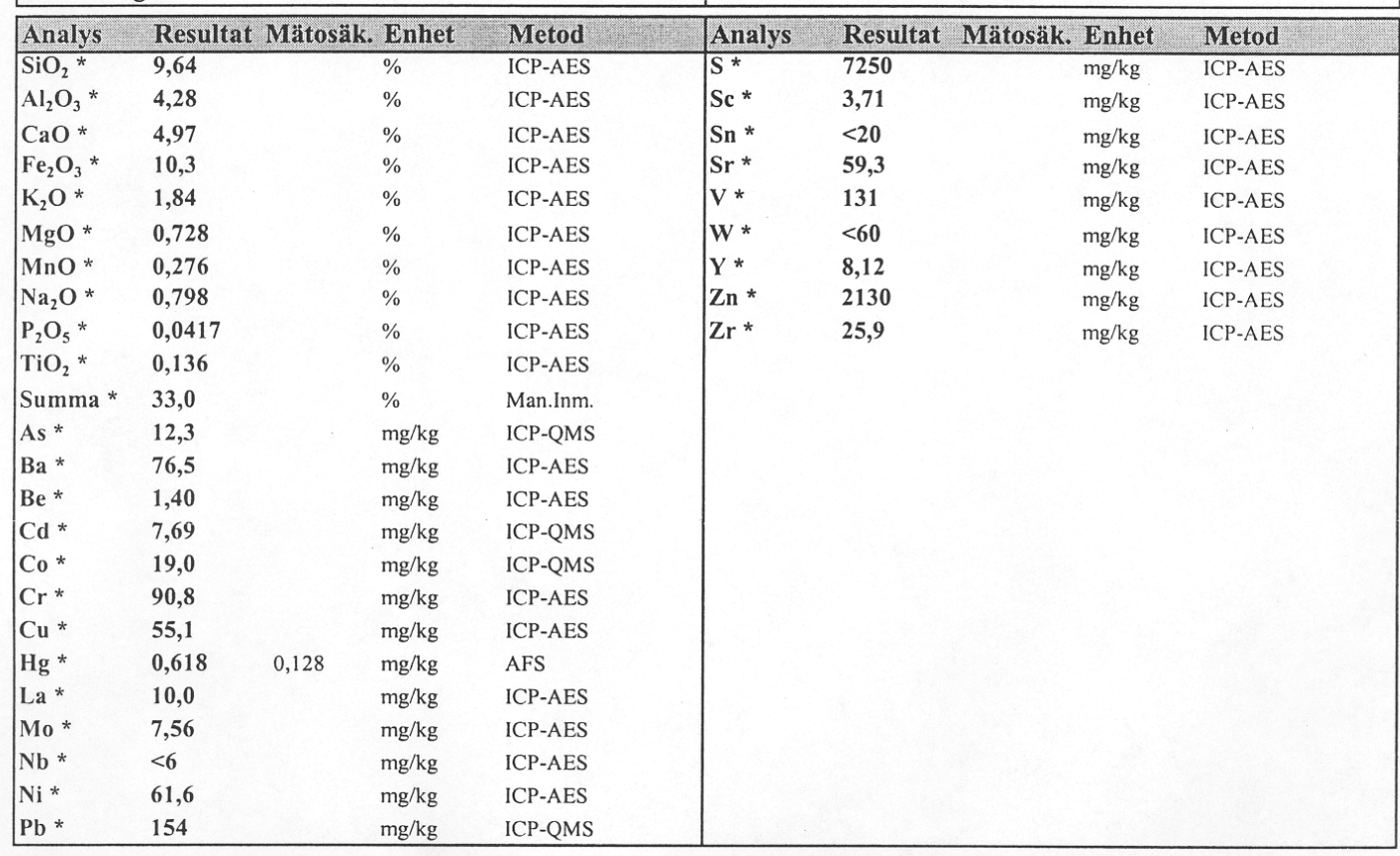

Vid analys av As, Cd, Cu, Co, Hg, Ni, Pb, Sb, Se och S gäller: Upplösning har skett enligt ASTM D3683

(modifierad). För övriga grundämnen har upplösning skett enligt ASTM D3682 ( $\mathrm{LiBO}_{2}-$ smälta).

Vid analys av B har upplösning skett i mikrovågsugn med HNO3.

Analys har skett en ligt EPA-metoder (modifierade) 200.7 (ICP-AES) och 200.8 (ICP-QMS).

U10097096-00: -97101 Förlite material för C-analys

Parametrar märkta med* indikerar ej ackrediterade analyser.

\begin{tabular}{lll}
\hline $\begin{array}{l}\text { Postadress } \\
\text { Aurorum 10 }\end{array}$ & Hemsida: & Telefon \\
$\begin{array}{l}\text { ww7 75 Luleå } \\
\text { Besöksadress }\end{array}$ & +46920289900 Kundtjänst \\
Aurorum 10 & $\begin{array}{l}\text { E-post } \\
\text { lulea@analytica.se }\end{array}$ & Fax \\
+46920289940
\end{tabular}




\section{DOE03QUAT RPT04DRAFT.DOC}

APPENDIX 7

PAGE 2

L0306059

Sidan 2 av 3

$\begin{array}{lll}\text { Er Order Id: } & & \text { MEFOS } \\ \text { Registrerad: } & 2003-06-26 & \text { L-E From } \\ \text { Analyserad: } & 2003-07-14 & \\ \text { Utfärdad: } & 2003-07-25 & \text { Box } 812 \\ & & 97125 \text { Luleå }\end{array}$

\begin{tabular}{|c|c|c|c|c|c|c|c|c|}
\hline \multirow{2}{*}{\multicolumn{2}{|c|}{$\begin{array}{l}\text { Analyspaket: } \\
\begin{array}{l}\text { Provnummer: } \\
\text { Beteckning 1: } \\
\text { Beteckning 2: }\end{array}\end{array}$}} & \multicolumn{3}{|c|}{ MG2-N } & & & & \\
\hline & & \multicolumn{3}{|c|}{$\begin{array}{l}\text { U10097097-00 } \\
\text { Prov } 21\end{array}$} & & & & \\
\hline Analys & Resultat & Mätosäk. & Enhet & Metod & Analys & Resultat & Mätosäk. Enhet & Metod \\
\hline $\mathrm{SiO}_{2}$ * & 0,881 & & $\%$ & ICP-AES & $\mathrm{S}^{*}$ & 1740 & $\mathrm{mg} / \mathrm{kg}$ & ICP-AES \\
\hline $\mathrm{Al}_{2} \mathrm{O}_{3}$ * & 0,280 & & $\%$ & ICP-AES & Sc * & $<1$ & $\mathrm{mg} / \mathrm{kg}$ & ICP-AES \\
\hline $\mathrm{CaO} *$ & 30,5 & & $\%$ & ICP-AES & $\mathrm{Sn}$ * & $<20$ & $\mathrm{mg} / \mathrm{kg}$ & ICP-AES \\
\hline $\mathrm{Fe}_{2} \mathrm{O}_{3}$ * & 15,4 & & $\%$ & ICP-AES & $\mathrm{Sr}$ * & 99,4 & $\mathrm{mg} / \mathrm{kg}$ & ICP-AES \\
\hline $\mathrm{K}_{2} \mathrm{O}$ * & 0,119 & & $\%$ & ICP-AES & $V^{*}$ & 93,9 & $\mathrm{mg} / \mathrm{kg}$ & ICP-AES \\
\hline $\mathrm{MgO}$ * & 0,907 & & $\%$ & ICP-AES & W* & $<60$ & $\mathrm{mg} / \mathrm{kg}$ & ICP-AES \\
\hline $\mathrm{MnO}$ * & 0,265 & & $\%$ & ICP-AES & $\mathrm{Y}^{*}$ & 3,82 & $\mathrm{mg} / \mathrm{kg}$ & ICP-AES \\
\hline $\mathrm{Na}_{2} \mathrm{O}$ * & 0,0561 & & $\%$ & ICP-AES & $\mathrm{Zn}$ * & 798 & $\mathrm{mg} / \mathrm{kg}$ & ICP-AES \\
\hline $\mathrm{P}_{2} \mathrm{O}_{5}$ * & 0,0183 & & $\%$ & ICP-AES & $\mathrm{Zr}$ * & 2,70 & $\mathrm{mg} / \mathrm{kg}$ & ICP-AES \\
\hline $\mathrm{TiO}_{2}$ * & 0,0062 & & $\%$ & ICP-AES & & & & \\
\hline Summa * & 48,4 & & $\%$ & Man.Inm. & & & & \\
\hline As * & 2,65 & & $\mathrm{mg} / \mathrm{kg}$ & ICP-QMS & & & & \\
\hline $\mathrm{Ba}$ * & 6,58 & & $\mathrm{mg} / \mathrm{kg}$ & ICP-AES & & & & \\
\hline $\mathrm{Be}$ * & $<0,6$ & & $\mathrm{mg} / \mathrm{kg}$ & ICP-AES & & & & \\
\hline$C d$ * & 0,386 & & $\mathrm{mg} / \mathrm{kg}$ & ICP-QMS & & & & \\
\hline $\mathrm{Co}^{*}$ & 9,25 & & $\mathrm{mg} / \mathrm{kg}$ & ICP-QMS & & & & \\
\hline $\mathrm{Cr}$ * & 46,9 & & $\mathrm{mg} / \mathrm{kg}$ & ICP-AES & & & & \\
\hline $\mathrm{Cu}$ * & 9,16 & & $\mathrm{mg} / \mathrm{kg}$ & ICP-QMS & & & & \\
\hline $\mathrm{Hg}$ * & $<0,1$ & & $\mathrm{mg} / \mathrm{kg}$ & AFS & & & & \\
\hline $\mathrm{La} *$ & $<6$ & & $\mathrm{mg} / \mathrm{kg}$ & ICP-AES & & & & \\
\hline Mo * & $<6$ & & $\mathrm{mg} / \mathrm{kg}$ & ICP-AES & & & & \\
\hline $\mathrm{Nb}$ * & $<6$ & & $\mathrm{mg} / \mathrm{kg}$ & ICP-AES & & & & \\
\hline $\mathrm{Ni}$ * & 24,7 & & $\mathrm{mg} / \mathrm{kg}$ & ICP-AES & & & & \\
\hline $\mathrm{Pb}$ * & 59,8 & & $\mathrm{mg} / \mathrm{kg}$ & ICP-QMS & & & & \\
\hline
\end{tabular}

Vid analys av $\mathrm{As}, \mathrm{Cd}, \mathrm{Cu}, \mathrm{Co}, \mathrm{Hg}, \mathrm{Ni}, \mathrm{Pb}, \mathrm{Sb}$, Se och $\mathrm{S}$ gäller: Upplösning har skett enligt ASTM D3683 (modifierad). För övriga grundämnen har upplösning skett enligt ASTM D3682 $\left(\mathrm{LiBO}_{2}-\right.$ smälta) .

Vid analys av B har upplösning skett i mikrovågsugn med HNO3.

Analys har skett en ligt EPA-metoder (modifierade) 200.7 (ICP-AES ) och 200.8 (ICP-QMS).

U10097096-00: -97101 Förlite material för C-analys

Parametrar märkta med * indikerar ej ackrediterade analyser.

\begin{tabular}{lll}
\hline Postadress & Hemsida: & Telefon \\
Aurorum 10 & www.analytica.se & +46920289900 Kundtjänst \\
97775 Luleå & E-post & Fax \\
Besöksadress & +46920289940 \\
Aurorum 10 & lulea@analytica.se & Signatur
\end{tabular}


Er Order Id: Registrerad: Analyserad: Utfärdad:
MEFOS

L-E From

Box 812

97125 Luleå

Analyspaket:

MG2-N

Provnummer:

Beteckning 1: U10097098-00

Beteckning 2: Prov 25

Analys Resultat Mätosäk. Enhet

$\mathrm{SiO}_{2}{ }^{*} \quad 1,16$

$\mathrm{Al}_{2} \mathrm{O}_{3}$ * 0,353

$\mathrm{CaO}$ * 33,7

$\mathrm{Fe}_{2} \mathrm{O}_{3}$ * $\quad 16,8$

$\mathrm{K}_{2} \mathrm{O}$ * $\quad 0,0969$

$\mathrm{MgO}$ * $\quad 0,896$

$\mathrm{MnO}$ * $\quad 0,0906$

$\mathrm{Na}_{2} \mathrm{O}$ * $\quad 0,0557$

$\mathrm{P}_{2} \mathrm{O}_{5}$ * $\quad 0,0234$

$\mathrm{TiO}_{2}$ * 0,0049

Summa * 53,2

As * $\quad 11,4$

$\mathrm{Ba} * \quad 28,6$

$\mathrm{Be} * \quad<0,6$

$C d * \quad 0,644$

$\mathrm{C}_{0}$ * $\quad 21,8$

$\mathrm{Cr} * \quad 22,8$

$\mathrm{Cu} * \quad 18,0$

$\mathrm{Hg} * \quad<0,2$

$\mathrm{La} *<6$

Mo * $\quad<6$

$\mathrm{Nb} * \quad<6$

$\mathrm{Ni}$ * $\quad 136$

$\mathrm{Pb}$ * $\quad 16,6$

Vid analys av $\mathrm{As}, \mathrm{Cd}, \mathrm{Cu}, \mathrm{Co}, \mathrm{Hg}, \mathrm{Ni}, \mathrm{Pb}$, Sb, Se och $\mathrm{S}$ gäller: Upplösning har skett enligt ASTM D3683 (modifierad). För övriga grundämnen har upplösning skett enligt ASTM D3682 ( $\mathrm{LiBO}_{2}-$ smälta) .

Vid analys av B har upplösning skett i mikrovågsugn med HNO3.

Analys har skett enligt EPA-metoder (modifierade) 200.7 (ICP-AES ) och 200.8 (ICP-QMS).

U10097096-00: -97101 Förlite material för C-analys

Parametrar märkta med * indikerar ej ackrediterade analyser.

\begin{tabular}{lll}
\hline Postadress & Hemsida: & Telefon \\
Aurorum 10 & www.analytica.se & +46920289900 Kundtjänst \\
97775 Luleå & E-post & Fax \\
Besöksadress & lulea@analytica.se & +46920289940 \\
Aurorum 10 & & Kemist
\end{tabular}


APPENDIX 7

PAGE 4

- S Analytica

\section{RAPPORT}

L0305883

Sidan 1 av 2

\begin{abstract}
Er Order Id:
Registrerad:

Analyserad:

Utfärdad:
\end{abstract}

MEFOS

L-E From

Box 812

97125 Luleå

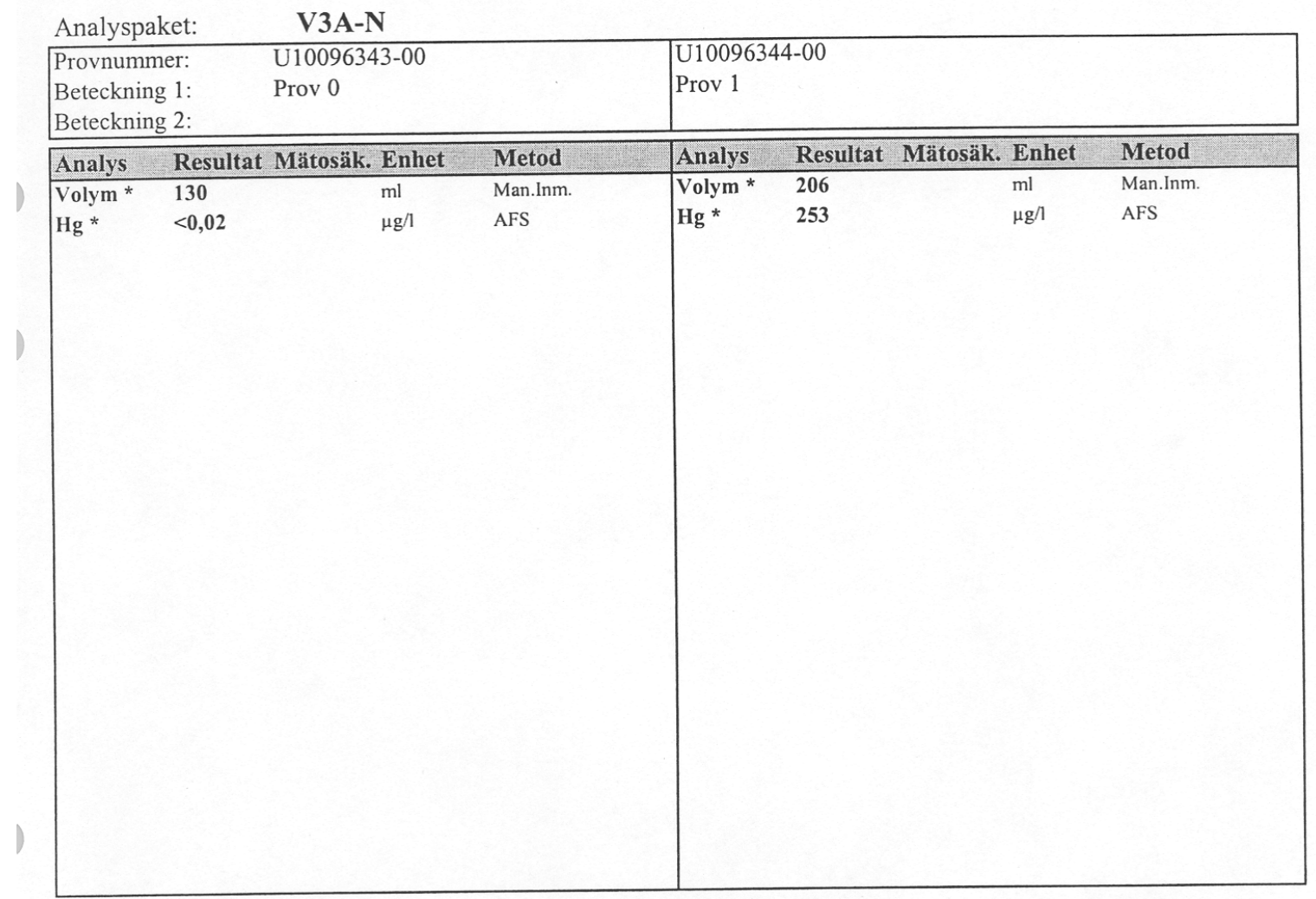

Analys av abso rptionslösning.

Analys har skett enligt EPA-metoder (modifierade) 200.7 (ICP-AES) och 200.8 (ICP-SMS).

Parametrar märkta med * indikerar ej ackrediterade analyser.

\begin{tabular}{lll}
\hline Postadress & Hemsida: & Telefon \\
Aurorum 10 & www.analytica.se & +46920289900 Kundtjänst \\
97775 Luleå & E-post & Fax \\
Besöksadress & lulea@analytica.se & +46920289940 \\
Aurorum 10 & Signatur
\end{tabular}


APPENDIX 7

PAGE 5

S Analytica

\section{RAPPORT}

\begin{abstract}
Er Order Id:
Registrerad:

Analyserad:

Utfärdad:
\end{abstract}

MEFOS

L-E From

Box 812

97125 Luleå

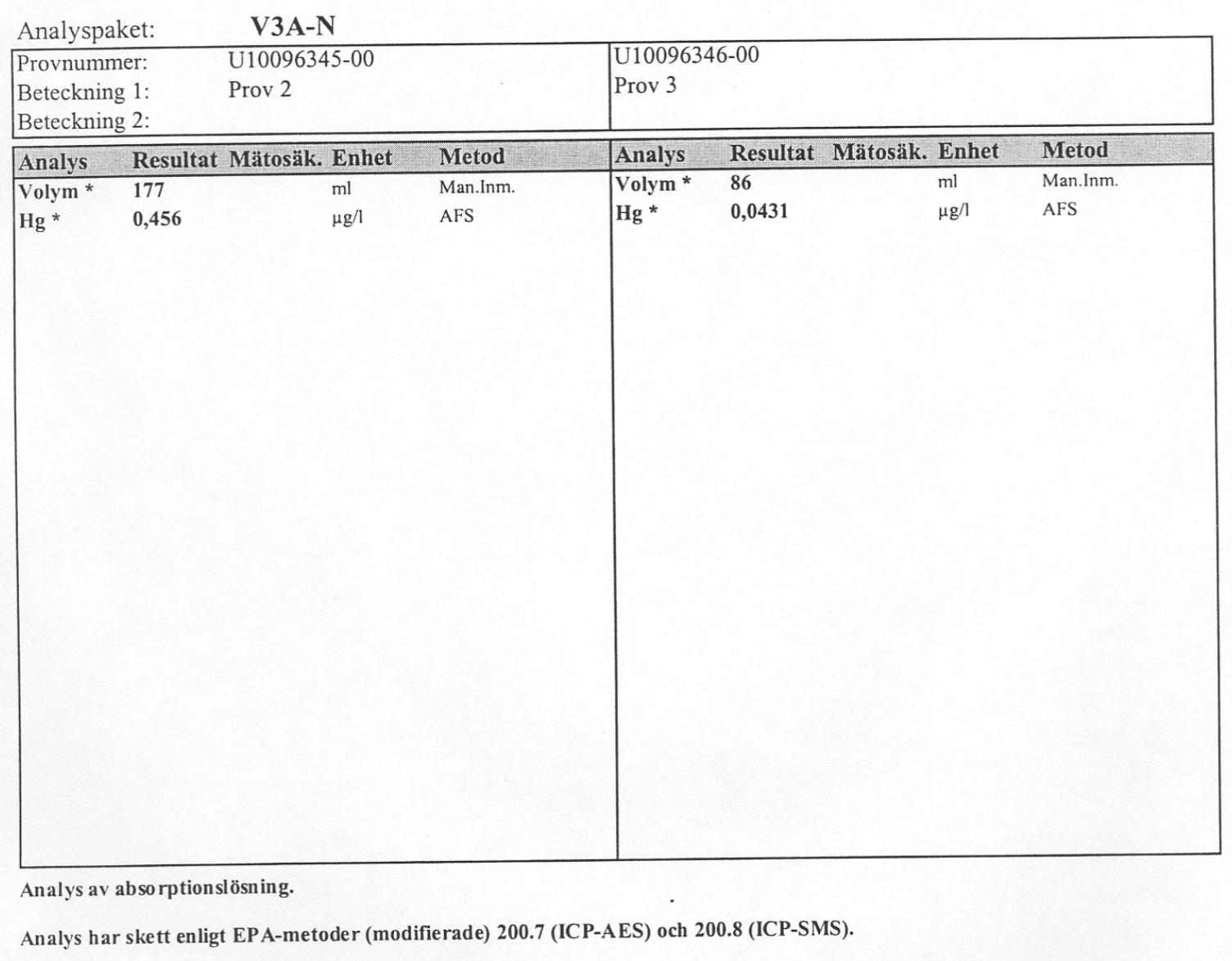

Parametrar märkta med * indikerar ej ackrediterade analyser.

\begin{tabular}{lll}
\hline Postadress & Hemsida: & Telefon \\
$\begin{array}{l}\text { Aurorum } 10 \\
\text { www.analytica.se }\end{array}$ & E-post & +46920289900 Kundtjänst \\
Besöksadress & lulea@analytica.se & Fax \\
Aurorum 10 & +46920289940
\end{tabular}




\section{Appendix II}

Kvaerner Process Flow, Hydrogen Purification, Amine and CO-Water Gas Shift Studies 


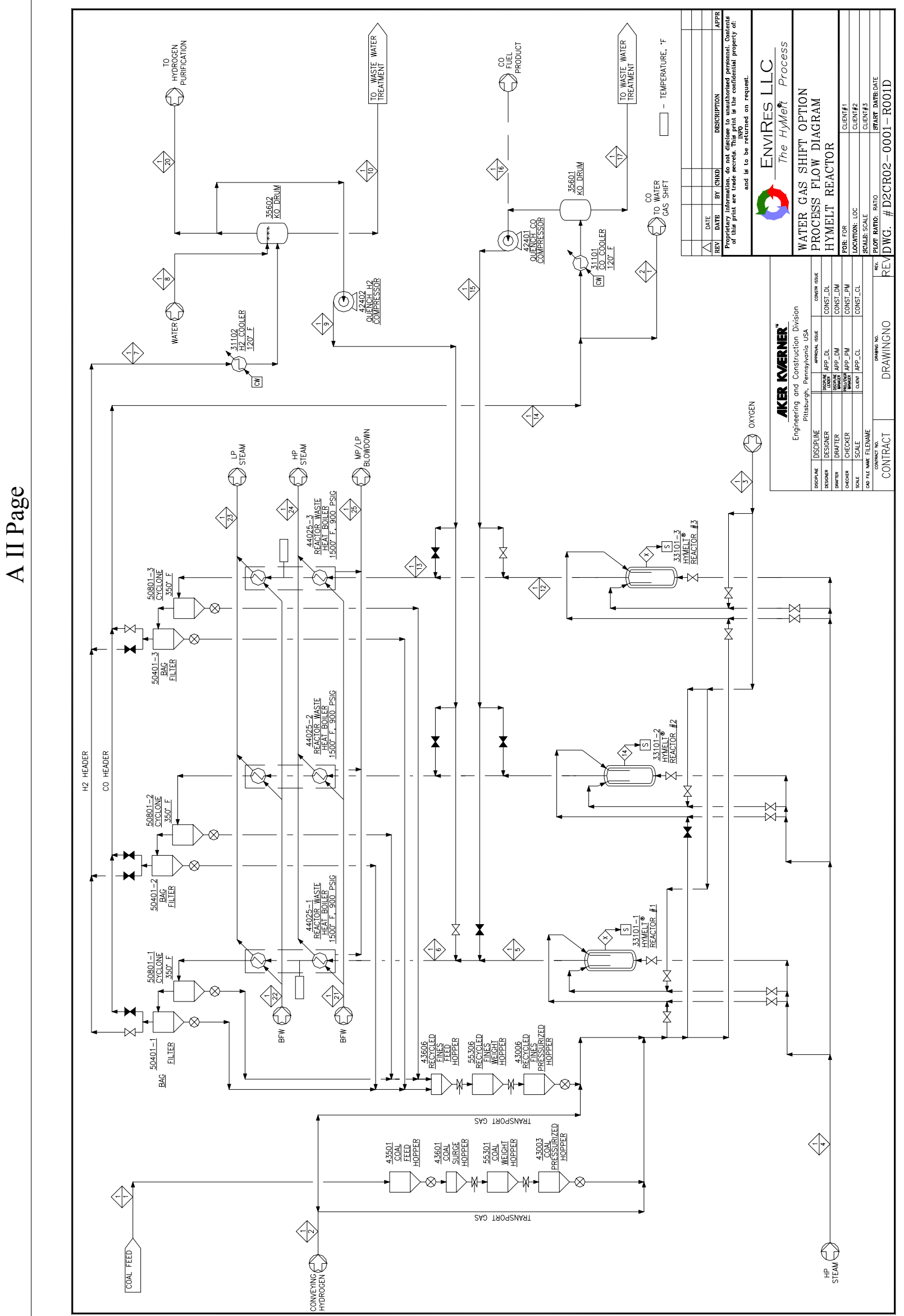


July 9, 2003

Email: mike.friedrich@akerkvaerner.com

Mr. Mike Friedrich

Aker Kvaerner

1200 Penn Avenue

Pittsburgh, PA 15222

SUBJECT: UOP Polybed PSA Unit

Envires, Kentucky

UOP Proposal P3H038 Rev. 4

Dear Mike,

In reply to your request, two budgetary designs and price estimates are provided for a UOP Polybed PSA Unit that produces a hydrogen product for the Hymelt Process. 
Case 1 produces 15.31 MMSCFD of product hydrogen and Case 2 produces 28.39 MMSCFD of product hydrogen.

If there are any questions, please contact me at 713-744-2863 or email: Eugene.kuchta@uop.com.

Sincerely,

Eugene Kuchta

Process Technology \& Equipment

EAK:rk 


\section{UOP POLYBEDTMPA UNIT}

for

\section{Kvaerner \\ Envires / Hymelt Process}

Project No: P3H038

\section{Case $1: 15.31$ MM SCFD Product}

$\underline{\text { Feed }}$

Flowrate,

MM SCFD

$\mathrm{lb}-\mathrm{mol} / \mathrm{hr}$

Pressure,

psig

Temperature, $\quad{ }^{\circ} \mathrm{F}$

${ }^{\circ} \mathrm{C}$
19.08

2,095

500

120

49 $\underline{\text { Product }}$

15.31

1,681

490

130

54
July 9, 2003 
Hydrogen Sulfide

Hydrogen Cyanide
$--$

0.05
A II Page 6 5.07

0.25

Design Hydrogen Recovery:

$86 \%$

PSA Price ( $\pm 20 \%$ FCA USA. Shop): $\quad \$ 1,700,000$ USD

PSA Approximate Plot Size:

$50 \mathrm{ft} . \times 30 \mathrm{ft}$.

PSA Utilities:

Instrument Air

Electric Power

Nitrogen (Startup only)

Leak Test

Purge
1,400 SCFH@85 psig

5.0 kW@120 VAC, 1 ph, 60 Hz

120,000 SCF@500 psig

60,000 SCF@85 psig 
UOP POLYBED ${ }^{T M P S A ~ U N I T ~}$

for

Kvaerner

Envires / Hymelt Process

Project No: P3H038

July 9, 2003

\section{Case 2 : 28.39 MM SCFD Product}

\section{$\underline{\text { Feed }}$}

Pressure, psig

Temperature, ${ }^{\circ} \mathrm{F}$

${ }^{\circ} \mathrm{C}$

\begin{abstract}
MM SCFD
lb-mol/hr

Flowrate,
\end{abstract}

lb-mol/hr

491

120

49

46.19

5,072

28.39

3,118

481

130

54

110

43

Composition, $\mathrm{mol} \%$

Hydrogen

71.40

99.9

25.94

Nitrogen

0.60

5.20

21.70

0.40

0.20
Carbon Monoxide

Carbon Dioxide

Methane

Water $\underline{\text { Product }}$

5 (Ex ST)
17.80

1,954

$\underline{\text { Tail Gas }}$

(Ex ST) 


$\begin{array}{lccc}\text { Hydrogen Sulfide } & 0.40 & -- & 1.04 \\ \text { Hydrogen Cyanide } & 0.10 & -- & 0.26\end{array}$

Design Hydrogen Recovery: $\quad 86 \%$

PSA Price ( $\pm 20 \%$ FCA USA Shop): $\quad \$ 2,500,000$ USD

PSA Approximate Plot Size:

$70 \mathrm{ft} . \times 40 \mathrm{ft}$.

PSA Utilities:

$\begin{array}{ll}\text { Instrument Air } & 3,400 \mathrm{SCFH} @ 85 \mathrm{psig} \\ \text { Electric Power } & 5.0 \mathrm{~kW} @ 120 \mathrm{VAC}, 1 \mathrm{ph}, 60 \mathrm{~Hz} \\ \text { Nitrogen (Startup only) } & \\ \quad \text { Leak Test } & 360,000 \mathrm{SCF} @ 491 \mathrm{psig} \\ \quad \text { Purge } & 180,000 \mathrm{SCF} @ 85 \mathrm{psig}\end{array}$




\title{
UOP POLYBED ${ }^{T M P S A ~ U N I T ~}$
}

\author{
for \\ Kvaerner \\ Envires / Hymelt Process
}

Project No: P3H038

July 9, 2003

UOP Scope of Supply includes

\author{
Adsorber Vessels \\ Off-Gas Drum(s) \\ Valve and Piping Skid \\ Initial Adsorbent Charge \\ Engineering \\ Control Panel with CRT \\ Relief Valves for Adsorber Vessels and Off-Gas Drum \\ Block Valves \\ Interconnecting Piping from Adsorber Vessels to Skid
}

Customer Scope of Supply includes

but is not limited to

Foundation including Anchor Bolts

Installation of All UOP Supplied Equipment

Piping from Valve and Piping Skid to Off-Gas Drum

Adsorbent Loading Under UOP Supervision 
Performance Test

A II Page 10

Piping To/From PSA Battery Limits

Wiring between Skid and Control Cabinet/CRT

Supply of Utilities

Leak and Pressure Test of the PSA Unit

Design and Supply of Peripheral Controls

- Product Back Pressure Control Valve

- Feed KO Drum

- Feed Flow Control

- Block Valves on All Piping To/From Unit

- Feed and Tail Gas Vent

- Tail Gas Flow/Pressure Control

Analyzer

Finish Paint

Notes:

1. The price is quoted exclusive of taxes, crating, insurance, or freight costs, and is based upon UOP standard fabrication and third quarter, 2003, costs.

2. The typical U.S. installation cost for Polybed ${ }^{\mathrm{TM}}$ PSA Units similar to the proposed system has been approximately $15 \%$ of UOP's quoted purchase price. 

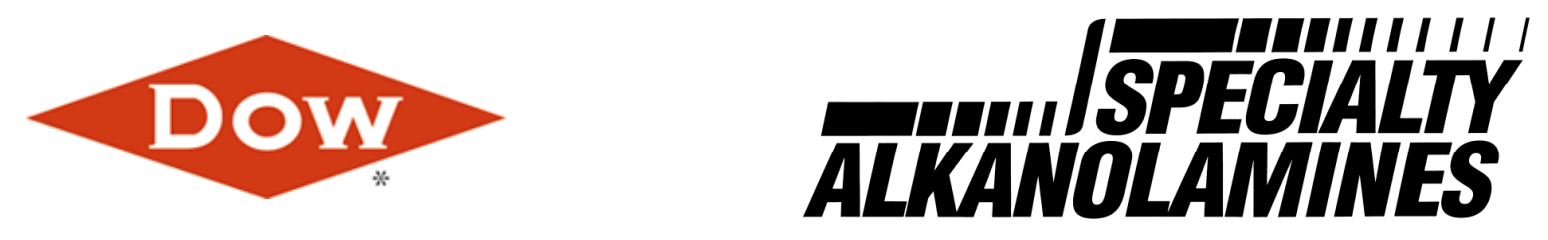

Gas Treating Products

Products, Technology and Service from Dow

\section{AkerKvaerner PSA TGU}

Feed and product Quality

Treated Gas Conditions

Solvent

Solution Conditions

Regenerator Conditions

Exchanger Data

Major Equipment Summary

Absorber

Regenerator

Reboiler

Lean/Rich Exchanger

Lean Solvent Cooler

Reflux Condenser

Stream Summary

Process Flow Diagram 


\section{AkerKvaerner PSA TGU}

Absorber Feed Gas Conditions

Gas Flow Rate:

Pressure:

Temperature:

Composition

$\mathrm{H} 2 \mathrm{~S}$

$\mathrm{CO} 2$

$\mathrm{H} 2$

$\mathrm{CO}$

$\mathrm{N} 2$

$\mathrm{C} 2 \mathrm{H} 6$

$\mathrm{C} 3 \mathrm{H} 8$

$\mathrm{H} 2 \mathrm{O}$

UCARSOL

TOTAL

Treated Gas Conditions

GAS FLOW RATE:

$\mathrm{H} 2 \mathrm{~S}$

$\mathrm{CO} 2$

CO2 Slippage

Solvent

Name

Lean Solvent Flow

Amine Strength

Internals - Number of Contact Trays

Solution Conditions

Lean Solvent Temperature

Lean Loading

Rich Loading

Regenerator Conditions:

Tower Internals - Number of Trays

Rich Amine Feed Temp

Reboiler Press

Reflux Flow

\section{Exchanger Data:}

Lean Cooler Duty

Lean - Rich Exch'r

Reflux Cond'r Duty

Reboiler Duty $\underline{\text { Simulation Summary }}$

22.09 MM SCFD

5.00 Psig

110.0 Deg F

Feed

Mol \%

LB MOL/HR

$0.86 \%$

$65.29 \%$

$20.10 \%$

$11.40 \%$

$1.02 \%$

$0.75 \%$

$0.02 \%$

$0.05 \%$

$0.51 \%$

$0.00 \%$

$100.00 \%$

20.98
$1,583.19$
487.47
276.52
24.69
18.09
0.58
1.16
12.32
0.00
$2,425.00$

Product

Mol\%

LB MOL/HR

$0.00 \%$
$60.56 \%$
$20.72 \%$
$11.75 \%$
$1.05 \%$
$0.77 \%$
$0.02 \%$
$0.05 \%$
$5.08 \%$
$0.00 \%$
$100.00 \%$

0.02
$1,424.87$

487.44

276.50

24.69

18.09
0.58

0.58
1.16

119.47

19.47
0.00

2,352.82
UCARSOL HS 103

560.0 GPM

$50.00 \%(\mathrm{~W} / \mathrm{W})$

10 TRAYS

10 PPMV

$63.8 \%(V / N)$ DRY

$90.0 \%$

100.0 Deg F

$0.005 \mathrm{Mol} / \mathrm{Mo}$

$0.159 \mathrm{Mol} / \mathrm{Mol}$

20 TRAYS

213.3 Deg F

13.0 Psig

31.8 GPM

13.681 MM BTU/HR

27.269 MM BTU/HR

17.221 MM BTU/HR

$32.619 \mathrm{MMBTU} / \mathrm{HR}$

The Dow Chemical Company assumes no obligation or liability resulting from the use of

this information. No warranty, expressed or implied, is given nor is freedom from any

patent owned by Dow or others to be inferred. Equipment sizes are estimated

and should be confirmed by normal rigorous engineering methods. 


\section{ALKANOLAMAMES}

\section{AkerKvaerner PSA TGU}

\section{Major Equipment Summary}

\section{Absorber}

Absorber Internals
Absorber Diameter
Lean Loading
Rich CO2 Loading
Rich H2S Loading
Atmospheric Pressure
Treated Gas H2S
Treated Gas CO2
Regenerator
Regenerator Internals
Regenerator Diameter
O/H Reflux Ratio
Regenerator Heat to Acid Gas Ratio
Steam to Feed Ratio

10 TRAYS

$7.6 \mathrm{FT}$

$0.005 \mathrm{Mol} / \mathrm{Mol}$

$0.141 \mathrm{Mol} / \mathrm{Mol}$

$0.019 \mathrm{Mol} / \mathrm{Mol}$

14.7 Psia

10.0 PPMV

$63.8 \%(\mathrm{~V} / \mathrm{V}) \mathrm{DRY}$

\author{
20 TRAYS \\ $6.3 \mathrm{FT}$ \\ $5.00 \mathrm{Mol} \mathrm{H} 2 \mathrm{O} / \mathrm{Mol} \mathrm{AG}$ \\ 181.954 M BTU/Mol Acid Gas \\ $1.077 \mathrm{LB} / \mathrm{GAL}$
}

$\underline{\text { Reboiler }}$

Heat Duty

Steam Rate

Reboiler Temperature

Reboiler Steam Pressure

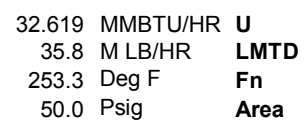

145.0 BTU/HR-FT2-DEGF

41.8 Deg F

1.00

5,384 SQFT

\section{Lean/Rich Exchanger}

Lean Outlet Temp
120 BTU/HR-FT2-DEGF

41.6 Deg $F$

0.80

6,836 SQFT

90 BTU/HR-FT2-DEGF

15.4 Deg F

0.80

$12,309 \mathrm{SQFT}$

64 BTU/HR-FT2-DEGF

49.7 Deg F

0.80

6,759 SQFT
Heat Duty

Rich Inlet Temp

Rich Outlet Temp

Lean Inlet Temp

\section{Lean Solvent Cooler}

Type

Heat Duty

Lean Inlet Temp

Lean Outlet Temp

\section{Reflux Condenser}

Type

Heat Duty

Inlet Temp

Outlet Temp

Reflux Flow Rate

\section{U}

27.269 MM BTU/HR LMTD

110.0 Deg F

213.3 Deg F

253.3 Deg $F$

153.1 Deg F

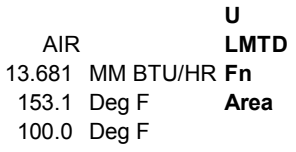

$\begin{array}{rll} & & \text { U } \\ \text { AIR } & \text { LMTD } \\ 17.221 & \text { MM BTU/HR Fn } \\ 231.6 & \text { Deg F } & \text { Area } \\ 120.0 & \text { Deg F } & \\ 31.8 & \text { GPM } & \end{array}$

The Dow Chemical Company assumes no obligation or liability resulting from the use of this information. No warranty, expressed or implied, is given nor is freedom from any patent owned by Dow or others to be inferred. Equipment sizes are estimated and should be confirmed by normal rigorous engineering methods. 


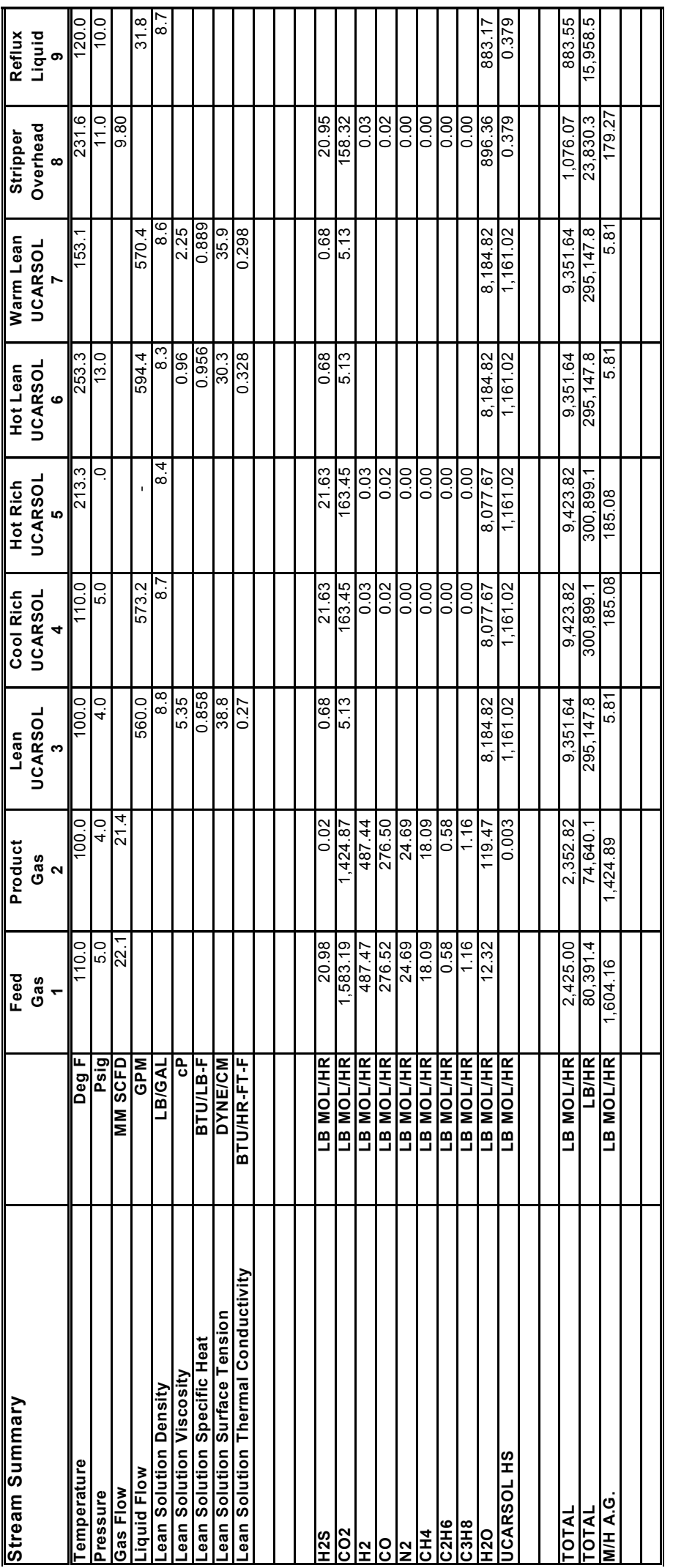

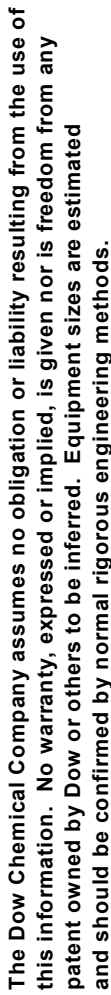




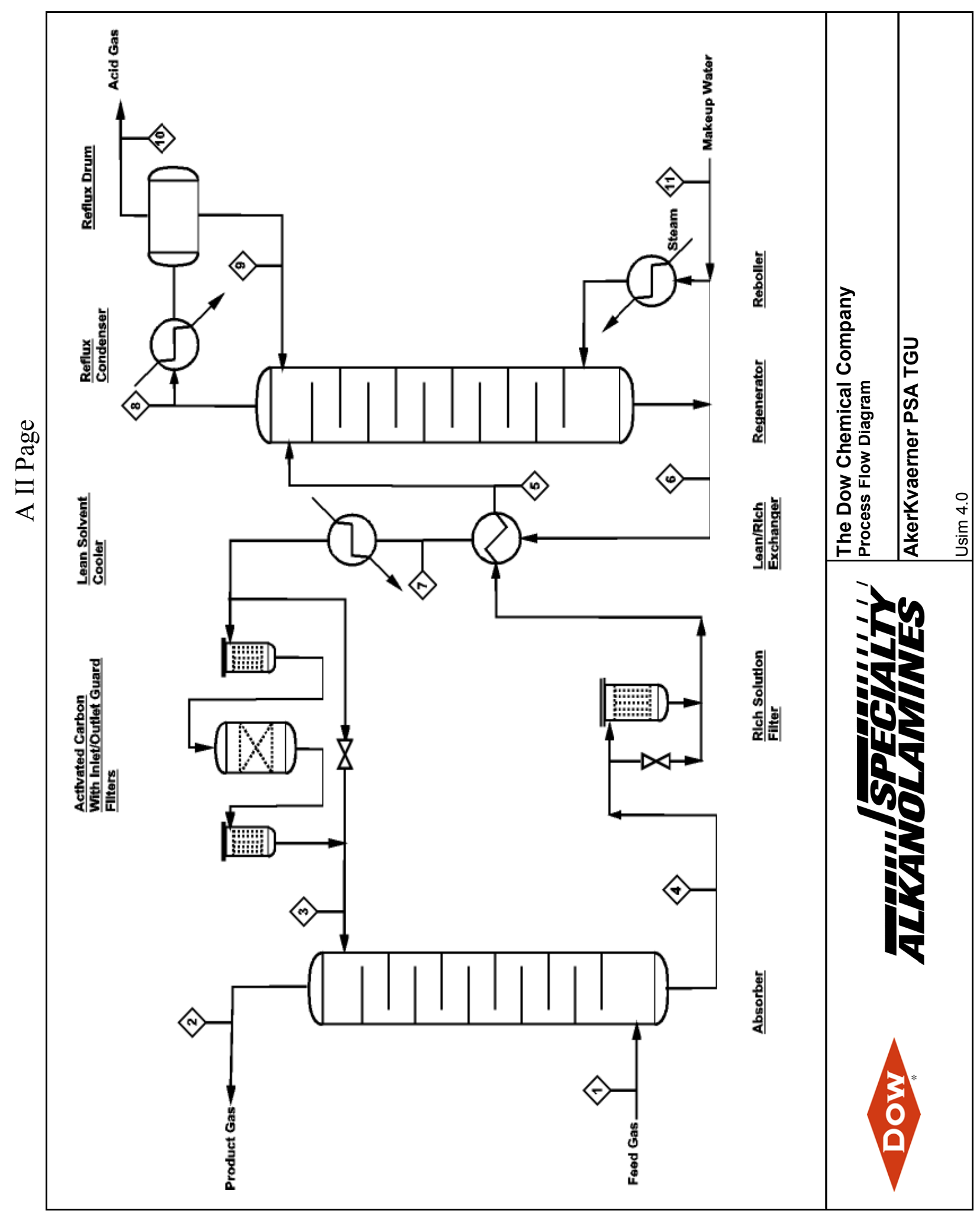




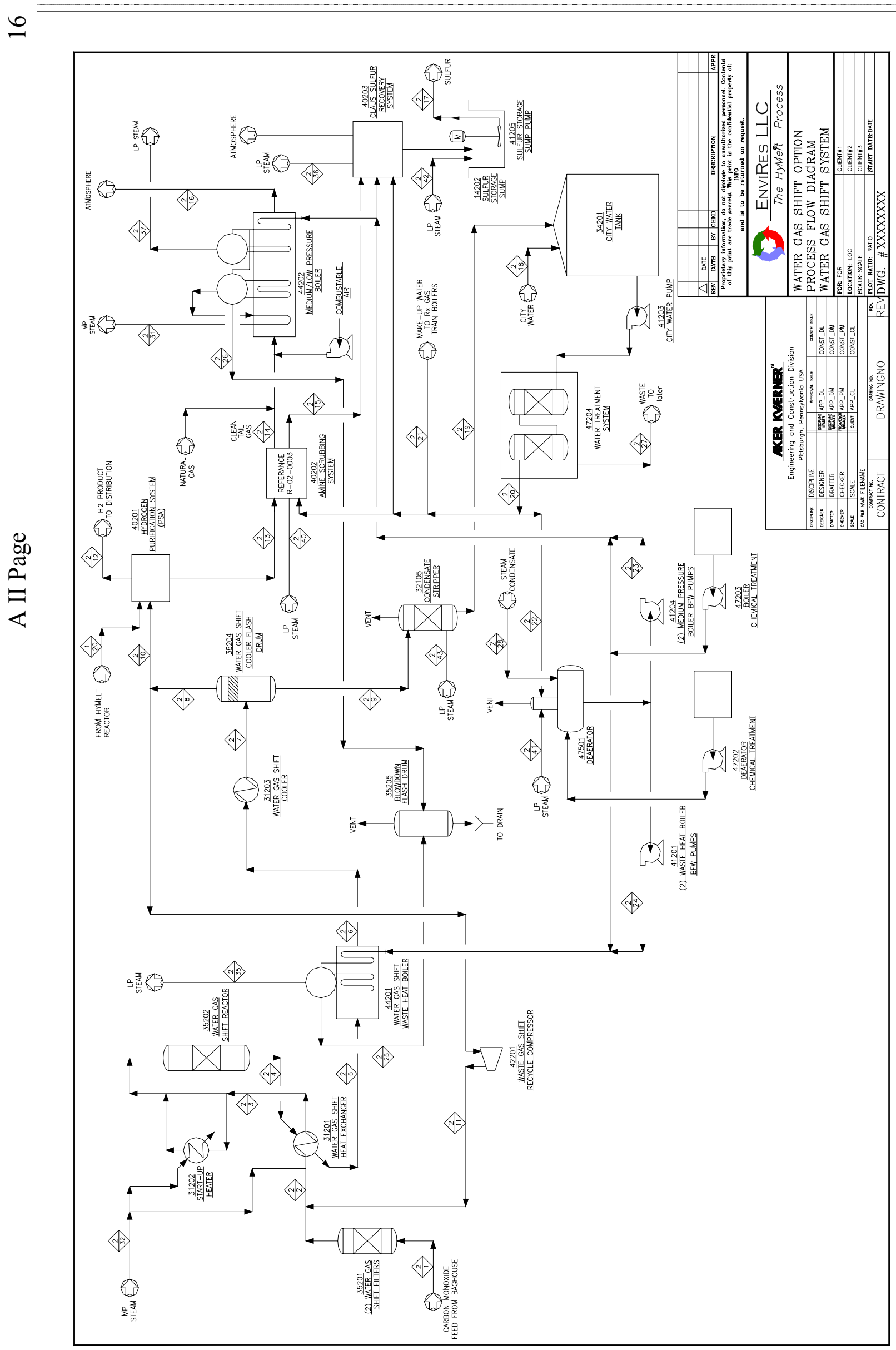




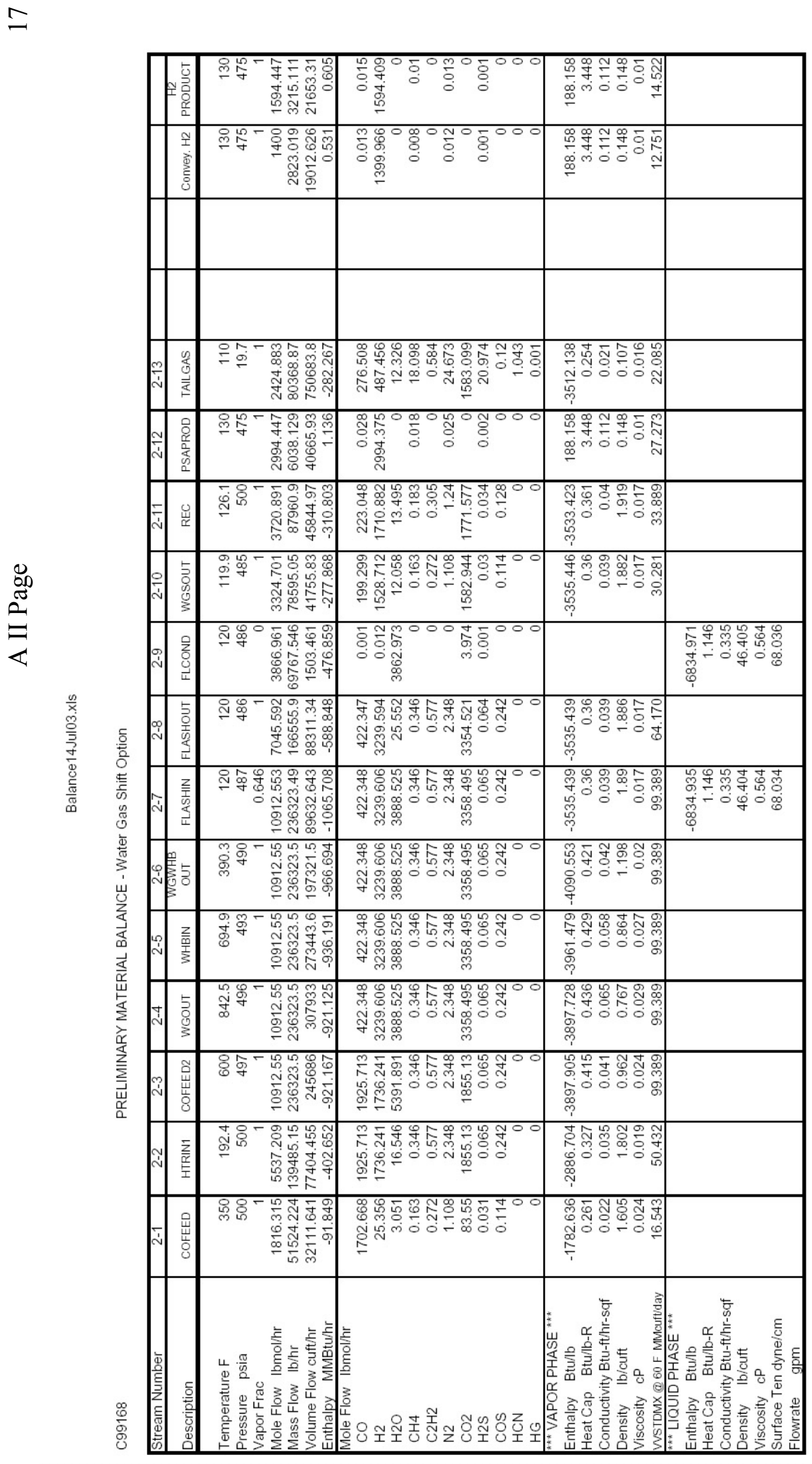




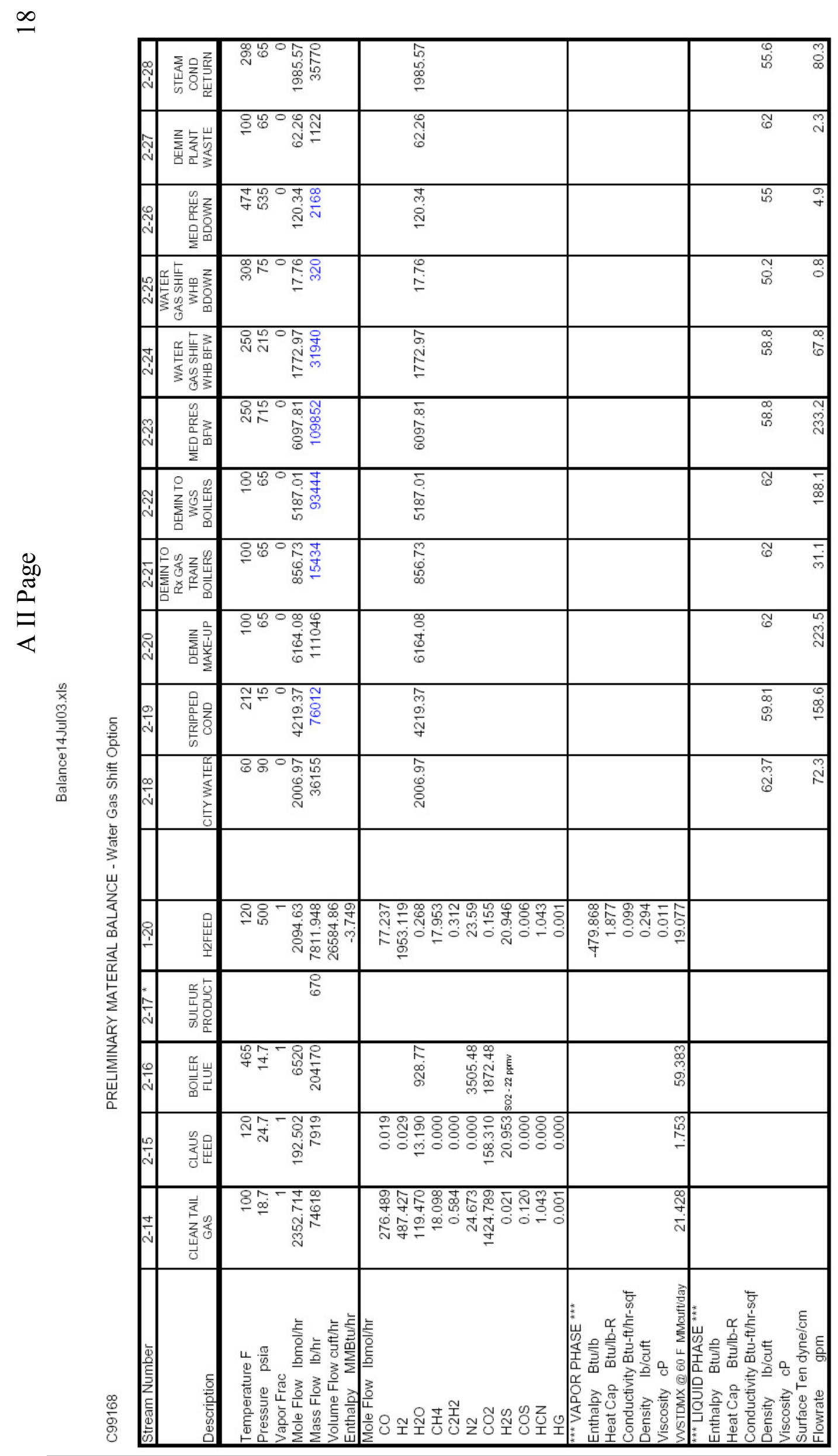




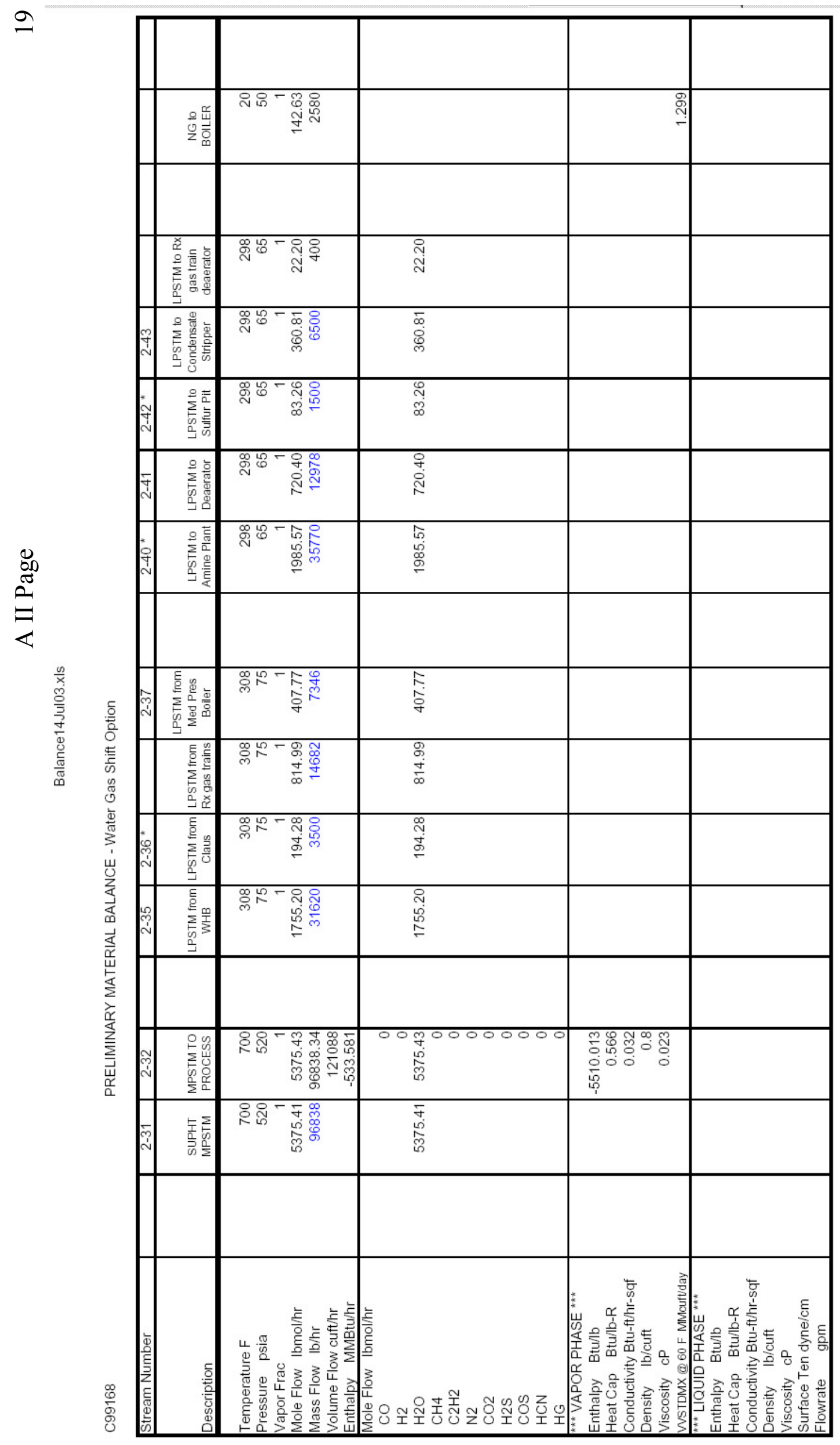


EnviRes LLC HyMelt Process

\begin{tabular}{|c|c|c|c|c|c|}
\hline $\begin{array}{l}\text { Equipment } \\
\text { Number }\end{array}$ & Quantity & $\begin{array}{l}\text { Operating/S } \\
\text { tandby }\end{array}$ & Description & Capacity/Size & $\begin{array}{l}\text { operating/ } \\
\text { connected }\end{array}$ \\
\hline 14202 & 1 & $1 / 0$ & Sulfur Storage Pit & 10,000 gallon & \\
\hline 31201 & 1 & $1 / 0$ & WGS Heat Exchanger & 15.1 MM Btu/h; Shell: 0.5 Mo; Tube: 316 SS & \\
\hline 31202 & 1 & $1 / 0$ & Start-up Heater & 5 MM Btu/h; Shell: CS; Tube: CS & \\
\hline 31203 & 1 & $1 / 0$ & WGS Cooler & 99.0 MM Btu/h; Shell\&Tube: 316 SS & \\
\hline 32105 & 1 & $1 / 0$ & Condensate Stripper & $3 \mathrm{ft}$ dia. $X 20^{\prime} \mathrm{T} / \mathrm{T} ; 10^{\prime}$ packed section; Shell SS & \\
\hline 34201 & 1 & $1 / 0$ & City Water Storage Tank & 400,000 gallons, CS & \\
\hline 35201 & 2 & $1 / 1$ & WGS Filter & $2 \mathrm{ft}$ dia. $X 10 \mathrm{ft}$ high, 500 psig, $120 \mathrm{~F}$ & \\
\hline 35202 & 1 & $1 / 0$ & Water Gas Shift Reactor & $10 \mathrm{ft}$ dia $\times 20 \mathrm{ft}$ high, $1.0 \mathrm{Cr}, 0.5 \mathrm{Mo}$ & \\
\hline 35204 & 1 & $1 / 0$ & WGS Cooler Flash Drum & $9 \mathrm{ft} . x 18 \mathrm{ft}$ high & \\
\hline 35205 & 1 & $1 / 0$ & Blowdown Flash Drum & $1.5 \mathrm{ft}$. dia $\times 3 \mathrm{ft}$. high & \\
\hline 35212 & 1 & $1 / 0$ & WGS Reactor Catalyst & $1050 \mathrm{ft} 3$ each reactor bed & \\
\hline 40201 & 1 & $1 / 0$ & H2 Purification System & 28 million SCFD H2 Product & \\
\hline 40202 & 1 & $1 / 0$ & Amine Scrubbing System & 22 MM SCFD feed & \\
\hline 40202.01 & 1 & $1 / 0$ & Absorber & $7.6 \mathrm{ft}$ dia. $\mathrm{X} 35^{\prime} \mathrm{T} / \mathrm{T} ; 10 \mathrm{SS}$ trays; Shell CS & \\
\hline 40202.02 & 1 & $1 / 0$ & Regenerator & $6.5 \mathrm{ft}$ dia. X 55' T/T; 20 SS trays; Shell CS & \\
\hline 40202.03 & 1 & $1 / 0$ & Lean/ Rich Exchanger & 27.3 MM Btu/hr; Plate\&Frame: 316 SS & \\
\hline 40202.04 & 1 & $1 / 0$ & Lean Solvent Cooler & 13.7 MM Btu/h; Plate\&Frame: 316 SS & \\
\hline 40202.05 & 1 & $1 / 0$ & Reflux Condenser & 17.2 MM Btu/h; Tubes: 316SS; Shell: CS & \\
\hline 40202.06 & 1 & $1 / 0$ & Reboiler & 32.6 MM Btu/h; Tubes: SS; Shell: CS & \\
\hline 40202.07 & 1 & $1 / 0$ & Reflux Drum & $3 \mathrm{ft}$ dia. $\times 6^{\prime} \mathrm{T} / \mathrm{T} ; \mathrm{SS}$ & \\
\hline 40202.08 & 1 & $1 / 0$ & Activated Carbon Bed & $8 \mathrm{ft}$ dia. X 14' T/T; CS; $530 \mathrm{cu} \mathrm{ft}$ activated carbon & \\
\hline 40202.09 & 1 & $1 / 0$ & Rich Solution Filter & 650 gpm; 50 micron; 8" line & \\
\hline 40202.10 & 1 & $1 / 0$ & Activated Carbon Inlet Guard Bed & 200 gpm; 10 micron; 4" line & \\
\hline 40202.11 & 1 & $1 / 0$ & Activated Carbon Outlet Guard Bed & 200 gpm; 10 micron; 4" line & \\
\hline 40202.12 & 2 & $1 / 1$ & Lean Solvent Pump & 700 gpm @ 50 psi; Shaft: SS & $40 / 80$ \\
\hline 40202.13 & 2 & $1 / 1$ & Rich Solvent Pump & 650 gpm @ 50 psi; Shaft: SS & $30 / 60$ \\
\hline 40202.14 & 2 & $1 / 1$ & Reflux Pump & 40 gpm @ 100 ft TDH ; SS & $2 / 4$ \\
\hline 40202.15 & 2 & $1 / 1$ & Make-up Pump & 150 gpm @ 100 ft TDH & $7.5 / 15$ \\
\hline 40202.16 & 1 & $1 / 0$ & Amine Storage Tank & 20,000 gal; underground & \\
\hline 40203 & 1 & $1 / 0$ & Claus Sulfur Recovery Plant & 8 tons/day skid mounted & \\
\hline 40203.01 & 1 & $1 / 0$ & Claus Plant Incinerator & $\begin{array}{l}\text { Operation at } 1000 \mathrm{~F} \mathrm{w} / \text { recuperator; } \\
0.83 \mathrm{MM} \mathrm{Btu/h} \text { fuel }\end{array}$ & \\
\hline 40205 & 1 & $1 / 0$ & CO Power Generation Plant & $\begin{array}{l}\text { Not included in this option as produce } 14.5 \mathrm{MM} \\
\text { SCFD Hydrogen ( } 9.5 \mathrm{MM} \text { SCFD more than base } \\
\text { case) }\end{array}$ & \\
\hline 41201 & 2 & $1 / 1$ & WH Boiler Feedwater Pump & $80 \mathrm{gpm} \times 200$ psi TDH & $20 / 40$ \\
\hline 41203 & 2 & $1 / 1$ & City Water Pump & $300 \mathrm{gpm} \times 100 \mathrm{ft} . \mathrm{TDH}$ & $15 / 30$ \\
\hline 41204 & 2 & $1 / 1$ & MP BFW Pump & $250 \mathrm{gpm} \times 700 \mathrm{psi}$ TDH & $150 / 300$ \\
\hline 41205 & 2 & $1 / 1$ & Sulfur Storage Pump & $100 \mathrm{gpm} \times 30 \mathrm{psi} \mathrm{TDH}$ & $5 / 10$ \\
\hline 41501 & 2 & $1 / 1$ & Cooling Tower Pump & $13,000 \mathrm{gpm} \times 50 \mathrm{psi} \mathrm{TDH}$ & $500 / 1000$ \\
\hline 42201 & 1 & $1 / 0$ & Water Gas Shift Recycle Compressor & 800 acfm $\times 25$ psi pressure rise, 500 psig discharge & $150 / 150$ \\
\hline 44201 & 1 & $1 / 0$ & WGS Waste Heat Boiler & $31,600 \mathrm{lbs} / \mathrm{hr}(60 \mathrm{psig})$ & \\
\hline 44202 & 1 & $1 / 0$ & Medium/ Low Pressure Boiler & $\begin{array}{l}97,000 \mathrm{lbs} / \mathrm{hr}(505 \mathrm{psig} / 700 \mathrm{~F}) \& 7,300 \mathrm{lbs} / \mathrm{hr}(60 \\
\mathrm{psig}) \\
\text { Est. one } 75 \mathrm{Hp} \text { comb air fan }\end{array}$ & $75 / 75$ \\
\hline 44301 & 1 & $1 / 0$ & Cooling Tower & $\begin{array}{l}130 \mathrm{MM} \text { Btu/hr; } 13,000 \mathrm{gpm} \text { circulation } \\
\text { Est. three fans @ } 125 \mathrm{Hp} \text { ea. }\end{array}$ & $375 / 375$ \\
\hline 47202 & 1 & $1 / 0$ & Deaerator Chemical Treatment System & Est. two $1 / 2 \mathrm{Hp}$ metering pumps & $0.5 / 1$ \\
\hline 47203 & 1 & $1 / 0$ & Boiler Chemical Treatment System & Est. two $1 / 2 \mathrm{Hp}$ metering pumps & $0.5 / 1$ \\
\hline 47204 & 1 & $1 / 0$ & Water Treatment System & $\begin{array}{l}250 \mathrm{gpm} \text { demin plant w/ inlet filter, regeneration } \\
\text { Est. two } 15 \mathrm{Hp} \text { demin pumps, two } 20 \mathrm{Hp} \text { blowers; } \\
\text { two } 15 \mathrm{Hp} \text { pumps for regen,etc. }\end{array}$ & $35 / 100$ \\
\hline 47501 & 1 & $1 / 0$ & Deaerator & $350 \mathrm{gpm}$; Storage Section - $6.5 \mathrm{ft}$ dia. $\times 21 \mathrm{ft} \mathrm{T} / \mathrm{T}$ & \\
\hline
\end{tabular}


Water Gas Shift Equipment List

C99268

EnviRes LLC HyMelt Process

Project Direct Cost Comparison to Base Case

\begin{tabular}{|l|l|r|r|}
\hline \multicolumn{3}{|c|}{ Equipment, Material Costs \& Field labor } \\
\hline Areas & Base Case & WGS Cost & WGS Delta \\
\hline Feed Prep & & & $\$ 0$ \\
Reactor Area & --- & 3113700 & $\$ 3,113,700$ \\
WGS Area & 1998200 & 2961400 & $\$ 963,200$ \\
Hydrogen Purification & 1593000 & 2371500 & $\$ 778,500$ \\
Amine Scrubbing & 2888500 & 3247000 & $\$ 358,500$ \\
Claus Plant & & & $\$ 3,511,700$ \\
Steam Generation & & --- & $\$ 0$ \\
Power Generation & & & $\$ 2,800,000$ \\
Utilities & & & $\$ 11,525,600$ \\
\end{tabular}

Results:

1.) WGS option ---> $\$ 22,083,050$ Project Total

Produce 9.5 MM SCFD more of hydrogen than base.

2.) Base Power Options (from CO)

Simple Cycle: Generate 17.8 MW for $\$ 15,200,000$

Combined Cyc: Generate $27 \mathrm{MW}$ for $\$ 30,600,000$ 
Water Gas Shift Equipment List

A II Page

C99268

EnviRes LLC HyMelt Process

Preliminary Economics of Water Gas Shift Option (Differential to Base Case)

\author{
Capital Cost Multiplier \\ Basis: \\ Avg. On-stream Factor \\ Amortization Parameters \\ Annual Interest Rate \\ Payoff Period
}

Estimated Differential Capital Costs:

Major Equipment Cost

Installed Equipment Cost

Direct Totals

Constr Equip \& Indirects

Constr. Mgt. Staff Supv

Freight

Taxes \& Permits

Engineering

Other Project Costs (Ovhd \& GA)

Contingency

Indirect Totals

Total Capital Cost

\begin{tabular}{cll|}
1 & \multicolumn{2}{l}{ Labor Rates (all-up): } \\
\cline { 3 - 3 } $\mathbf{9 0 \%}$ & Engineering & $\mathbf{8 0} \$ / \mathrm{hr}$ \\
& Field Labor & $70 \$ / \mathrm{hr}$ \\
& Constr. Mgt & $\mathbf{8 5} \$ / \mathrm{hr}$ \\
\hline
\end{tabular}

$10 \%$

20 years

\begin{tabular}{|c|c|c|}
\hline $\begin{array}{r}6,206,000 \\
5,319,800 \\
11,525,800\end{array}$ & Field Hrs & 49300 \\
\hline$\$ 2,305,160$ & $\%$ Directs & $20 \%$ \\
\hline$\$ 794,100$ & $\%$ Field Hrs & $18.95 \%$ \\
\hline$\$ 366,520$ & $\%$ Directs & $3.18 \%$ \\
\hline$\$ 504,830$ & $\%$ Directs & $4.38 \%$ \\
\hline$\$ 2,545,600$ & Manhours & 31820 \\
\hline$\$ 1,342,339$ & $\%$ Above Indirects & $20.60 \%$ \\
\hline$\$ 3,420,768$ & $\%$ Total & $15.00 \%$ \\
\hline
\end{tabular}

Differential Operating \& Maintenance Costs, \$ per year:

Natural Gas@ @ / MM Btu

Electricity@ cents / kwh

Cooling Water Chem @ cents/kgal

BFW Chem @ cents/kgal

LP Stm (from Reactor) @ \$ / k lb

Operation/ Maint @ \$ / manhr

Insur \& Taxes @ 1\% Capital/yr

O \& M Mgt Fees

Spare Parts @ 5\% Major Equip/yr

Total O \& M Cost

Amortization Cost @ \% capital/yr

Total Yearly Costs

Differential Sales, \$ per year:

CO Fuel Lost @ \$ / MM Btu

PSA TailGas Fuel Lost @ \$ / MM Btu

Total Sales

Net Hydrogen Production Cost, \$ per year

Net Hydrogen Production Cost, \$ per k scf

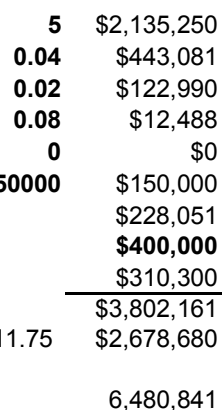

$2.5-\$ 4,142,960$

$1.5 \quad-\$ 648,459$

$-\$ 4,791,419$

$\$ 11,272,260$

$\$ \quad 2.86$

\begin{tabular}{|rr|lr|}
\hline MM SCFD & 1.3 & Btu/SCF & 1000 \\
kwh & 1405 & \\
gpm & 13000 & \\
gpm & 330 & \\
Ib/hr consumed & 14300 & \\
No. of addnl & 3 & \\
\cline { 1 - 2 } & &
\end{tabular}

\begin{tabular}{lr|ll|}
\hline MM SCFD & $-\mathbf{1 6 . 5 4}$ & Btu/SCF & 305 \\
MM SCFD & $\mathbf{- 3 . 7 6}$ & Btu/SCF & $\mathbf{3 5 0}$ \\
\hline
\end{tabular}


A III Page 1

Appencix III

Siemens Westinghouse Power Corporation 
A III Page 2

Selection issues for the DF-42 and catalytic burners are compared in Table Alll 1.

Table A III 1

Candidate Burner Comparison

\begin{tabular}{|c|c|}
\hline DF-42 & Catalytic \\
\hline
\end{tabular}

Technical Areas

\begin{tabular}{|l|l|l|}
\hline Commercial fleet & $(+)$ Many running units & $(-)$ None running \\
\hline Proven on CO/H $\mathrm{H}_{2}$ fuel? & $(-)$ No & $(-)$ No \\
\hline NOx control & $\begin{array}{l}(-) \text { Burner designed for } \\
42 \text { ppm with diesel fuel } \\
\text { (DF). May get 25 ppm } \\
\text { with syngas. Needs } \\
\text { steam or water injection, } \\
\text { plus SCR }\end{array}$ & $\begin{array}{l}\text { (+) Lowest NOx } \\
\text { bursion. Catalytic } \\
\text { burner has tested } \\
\text { capability to achieve } \\
\text { around 2 ppm NOx } \\
\text { without SCR (but not with } \\
\text { this fuel). SCR may not } \\
\text { be needed. }\end{array}$ \\
\hline $\begin{array}{l}\text { Dual-fuel capability } \\
\text { (natural gas and high-CO } \\
\text { syngas) }\end{array}$ & $\begin{array}{l}(+) \text { Dual-fuel capable } \\
\text { may be complicated. }\end{array}$ \\
\hline
\end{tabular}

Programmatic Areas

\begin{tabular}{|l|l|l|}
\hline Technology advancement & $($ - $)$ Mainly adaptation of & $(+)$ Development of new
\end{tabular}

\begin{tabular}{|l|l|l|} 
& an existing design & type of burner \\
\hline Scalability & $(-) \sim 1 / 250$ scale testing & $(+)$ full-scale testing \\
\hline Burner geometry model & $(-)$ Model needed & $(+)$ STC has model \\
\hline $\begin{array}{l}\text { Transition geometry } \\
\text { model }\end{array}$ & $(-)$ Model needed & $(-)$ Model needed \\
\hline Kinetics model & All by CS\&E & $\begin{array}{l}\text { Catalytic partial reactions } \\
\text { by STC, downstream } \\
\text { combustion by CS\&E }\end{array}$ \\
\hline Test burner design & $(-)$ Design needed & $(+)$ Design complete \\
\hline Test burner fabrication & $(-)$ Hardware needed & $\begin{array}{l}\text { ( ?) Hardware may be } \\
\text { needed }\end{array}$ \\
\hline
\end{tabular}

Commercial Areas

\begin{tabular}{|l|l|l|}
\hline GT (w/burner) capital cost & $(+)$ Slightly less? & $(-)$ Slightly more? \\
\hline SCR capital cost & $(-)$ SCR needed & $\begin{array}{l}\text { ( ? ) SCR may not be } \\
\text { needed }\end{array}$ \\
\hline SCR operating cost & $(-)$ SCR needed & $\begin{array}{l}(+) \text { less than for DF-42, } \\
\text { maybe zero. }\end{array}$ \\
\hline Development needed & $\begin{array}{l}\text { (+) Basic burner is } \\
\text { developed, may need } \\
\text { modification }\end{array}$ & $\begin{array}{l}(-) \text { Burner development } \\
\text { needed }\end{array}$ \\
\hline Commercial Availability & (+) Sooner & ( - ) Later \\
\hline
\end{tabular}




\section{EnviRes High-CO Gas Turbine Study Specification}

This document describes the key parameters that form the boundary conditions, for the conceptual design of a gas turbine operating with HyMelt off-gas. This is intended to be a working document that can be updated throughout the project by Siemens Westinghouse.

\section{Contents}

REVISIONS

$\begin{array}{ll}\text { SYNGAS COMPOSITIONS } & 4\end{array}$

GAS TURBINE SIZE $\quad 5$

USE OF NATURAL GAS $\quad 5$

EMISSION LIMITS

\section{Revisions}

Rev. Date Description of Change

A 22 Oct 03 Original Issue 


\section{Syngas Composition}

The composition, temperature, and pressure of HyMelt syngas from Illinois \#6 Coal are shown in Table 2. The syngas from petroleum coke will be virtually identical to that from coal. The contaminants listed in Table 2 are all expected to be less than 1 ppmv.

Table A III 2

Illinois \#6 Coal Syngas Composition

Composition

\begin{tabular}{rcc}
$\mathrm{CH}_{4}$ & 0.07 & $\%(\mathrm{vol})$ \\
$\mathrm{CO}$ & 75.72 & $\%(\mathrm{vol})$ \\
$\mathrm{CO}_{2}$ & 3.92 & $\%(\mathrm{vol})$ \\
$\mathrm{COS}[1]$ & - & $\%(\mathrm{vol})$ \\
$\mathrm{H}_{2}$ & 19.96 & $\%(\mathrm{vol})$ \\
$\mathrm{H}_{2} \mathrm{O}$ & 0.30 & $\%(\mathrm{vol})$ \\
$\mathrm{H}_{2} \mathrm{~S}[1]$ & - & $\%(\mathrm{vol})$ \\
$\mathrm{N}_{2}$ & 0.03 & $\%(\mathrm{vol})$ \\
\hline Total & 100.00 & $\%(\mathrm{vol})$
\end{tabular}

Properties

\begin{tabular}{rclll} 
Temperature & 160 or lower ${ }^{\circ} \mathrm{F}$ & \multicolumn{2}{c}{71 or lower ${ }^{\circ} \mathrm{C}$} \\
Pressure & 365 to $415 \mathrm{psia}$ & 25 to 29 & $\mathrm{bar}$ \\
HHV & 309 & Btu/scf & 12.16 & $\mathrm{MJ} / \mathrm{Nm}^{3}$ \\
HHV & 4,995 & Btu/lb & 11.61 & $\mathrm{MJ} / \mathrm{kg}^{3}$ \\
LHV & 298 & Btu/scf & 11.76 & $\mathrm{MJ} / \mathrm{Nm}^{3}$ \\
LHV & 4,832 & Btu/lb & 11.23 & $\mathrm{MJ} / \mathrm{kg}$
\end{tabular}

$\underline{\text { Contaminants }}$

$\begin{aligned} \text { Barium (Ba) } & \operatorname{ppm}(w) \\ \text { Calcium }(\mathrm{Ca}) & \operatorname{ppm}(\mathrm{w}) \\ \text { Chlorides }(\mathrm{Cl}) & \operatorname{ppm}(\mathrm{w}) \\ \text { Copper }(\mathrm{Cu}) & \operatorname{ppm}(\mathrm{w}) \\ \text { Iron }(\mathrm{Fe}) & \operatorname{ppm}(\mathrm{w}) \\ \text { Lead }(\mathrm{Pb}) & \operatorname{ppm}(\mathrm{w}) \\ \text { Magnesium }(\mathrm{Mg}) & \operatorname{ppm}(\mathrm{w}) \\ \text { Manganese }(\mathrm{Mn}) & \operatorname{ppm}(\mathrm{w}) \\ \text { Nickel }(\mathrm{Ni})[1] & \operatorname{ppm}(\mathrm{w}) \\ \text { Phosphorus }(\mathrm{P})[1] & \operatorname{ppm}(\mathrm{w}) \\ \text { Potassium (K) } & \operatorname{ppm}(\mathrm{w}) \\ \text { Silica }(\mathrm{SiO} 2) & \operatorname{ppm}(\mathrm{w}) \\ \text { Silicon }(\mathrm{Si}) & \operatorname{ppm}(\mathrm{w}) \\ \text { Sodium }(\mathrm{Na}) & \operatorname{ppm}(\mathrm{w}) \\ \text { Vanadium }(\mathrm{V}) & \operatorname{ppm}(\mathrm{w}) \\ \text { Zinc }(\mathrm{Zn}) & \operatorname{ppm}(\mathrm{w}) \\ \text { Other trace metals } & \operatorname{ppm}(\mathrm{w})\end{aligned}$

[1] These constituents may be harmful to catalysts. 


\section{Gas Turbine Size}

The original proposal assumed that the HyMelt $\AA$ process module would produce about 1157 million Btu/hr of CO-rich gas, which was slightly less than the fuel requirements of a W501D5A gas turbine. The actual gasification module may produce more gas, which would match the fuel requirements of a larger turbine or turbines.

Table 3 lists the approximate syngas consumption of the three W-class gas turbines in $1 \times 1$ and $2 \times 1$ combined cycle arrangements. More detailed calculations performed during the project will determine the actual syngas requirements.

Table A III 3

\section{Estimated Gas Turbine Syngas Consumption}

Combined Cycle Plant Million Btu/h Million scf $/ \mathrm{h}[1]$ Designation Gas Turbine Combined Cycle Power, Power, MW MW

\begin{tabular}{lcccc}
\hline 1x1.W501D5A & 1,169 & 3.9 & 121 & 173 \\
1x1.W501FD & 1,726 & 5.8 & 190 & 283 \\
1x1.W501G & 2,146 & 7.2 & 253 & 365 \\
2x1.W501D5A & 2,338 & 7.8 & 241 & 346 \\
2x1.W501FD & 3,452 & 11.6 & 379 & 567 \\
2x1.W501G & 4,292 & 14.4 & 506 & 730
\end{tabular}

[1] Estimated consumption of syngas with an LHV of 298 Btu/scf.

\section{Use of Natural Gas}

Natural gas is the preferred fuel for start-up and, if necessary during shutdown.

\section{Emission Limits}

The two tentative plant sites are

A. East St. Louis, Illinois

B. Decatur, Illinois

In the absence of specific information about emission limits at these sites, the values of 2 ppmv for both $\mathrm{CO}$ and NOx seem to be the best choice. In the near future, stack emissions are projected to be as low as 2 ppmv NOx and 2 ppmv CO when corrected to $0 \%$ moisture and $15 \%$ oxygen. These projections are based on (1) current limits in California, Massachusetts, New York, and New Hampshire of 2.5 to 3.5 ppmv NOx, and (2) the current best available emission control technology (BACT) can achieve 2-3 ppmv for both NOx and CO. These limits are not expected to be relaxed during the next 15 years.

If the gas turbine exhaust contains $\mathrm{NOx}$ and $\mathrm{CO}$ emissions higher than the target levels, some exhaust gas treatment, such as selective catalytic reduction, will have to be added. 